UNIVERSIDADE DE SÃO PAULO

INSTITUTO DE GEOCIÊNCIAS

\title{
ESTUDO GEOQUÍMICO E MICROFAUNÍSTICO DA REGIÃO CIRCUNJACENTE AO EMISSÁRIO SUBMARINO DE ESGOTO DAS CIGARRAS, SÃO SEBASTIÃO, SP
}

\author{
Luciana Saraiva Filippos
}

Orientadora: Profa. Dra. Wânia Duleba

\section{DISSERTAÇÃO DE MESTRADO}

Programa de Pós-Graduação em Geoquímica e Geotectônica

\author{
SÃO PAULO
}


"O homem é parte da natureza e sua guerra contra ela é inevitavelmente uma guerra contra si mesmo... Temos pela frente um desafio como nunca a humanidade teve, de provar nossa maturidade e domínio, não da natureza, mas de nós mesmos".

Rachel Carson 


\section{AGRADECIMENTOS}

À minha orientadora Wania Duleba pela ajuda, dedicação, encaminhamento e incentivo para o meio acadêmico, assim como por todas as conversas.

À Andréia Teodoro por toda paciência, orientação e ajuda ao longo do mestrado.

À Juliana Braga e Silva e Silas Gubitoso pela ajuda, conversas e risadas.

Ao Felipe Lamus Ochoa pelo carinho, apoio e amizade.

Ao Isaac Jamil Sayeg pelas conversas, ensinamentos e realização das fotomicrografias dos foraminíferos.

À Miriam L. A. F. Pacheco pela ajuda com os dados estatísticos.

À Profa. Dra. Christine Burrote pela ajuda com os hidrocarbonetos.

Ao Prof. Dr. Décio Semensatto pela ajuda com os dados estatísticos.

Ao Prof. Dr. Thomas Rich Fairchild pela correção do abstract.

Aos funcionários da biblioteca do Instituto de Geociências e do Instituto de Oceanografia pelo auxílio na busca de livros e artigos.

À Ana Paula Cabanal e Magaly Poli Fernandes Rizzo da secretaria de pós-graduação e ao Tadeu Caggiano pela ajuda ao longo do mestrado.

A todos os funcionários do IgC, do xérox, da gráfica, da portaria e faxineiras.

À Sandra Andrade pelo auxílio nas análises de carbono, enxofre e nitrogênio.

À CETESB pelo compartilhamento dos dados físico-químicos da água e pelas amostras de sedimento.

Ao Labcorp pela atenção e ajuda nas análises dos hidrocarbonetos.

Aos meus pais, irmãs e familiares pelo carinho apoio nesta jornada.

Ao Zylber pelo eterno carinho, amor, compreensão, ajuda e paciência.

A todas as pessoas que me apoiaram e ajudaram a concluir mais esta etapa profissional.

À CNPq pela bolsa durante meu primeiro semestre do mestrado.

À FAPESP pelo fornecimento do restante da bolsa de mestrado e reserva técnica. 


\section{SUMÁRIO}

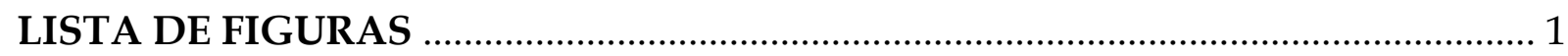

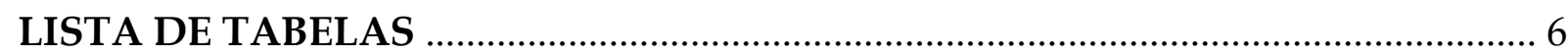

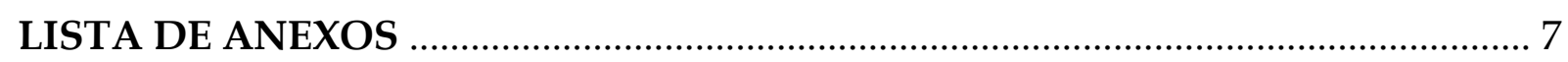

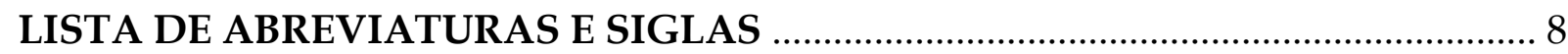

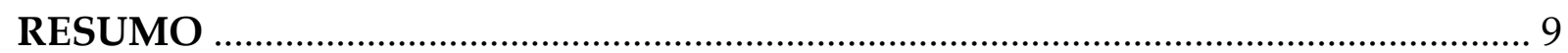

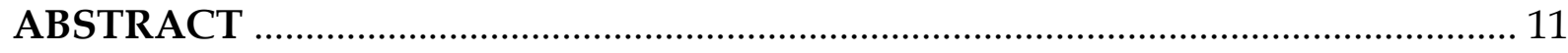

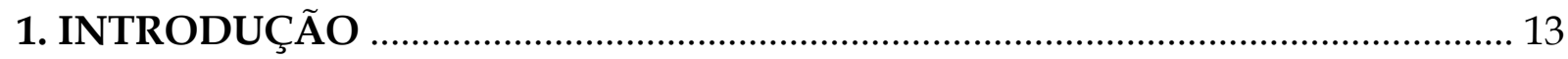

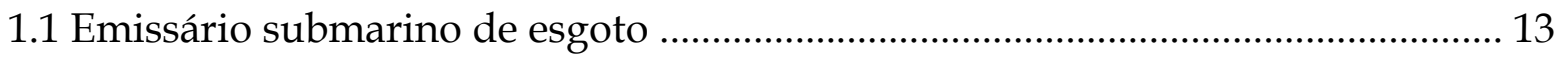

1.2 Hidrocarbonetos Policíclicos Aromáticos (HPAs) ................................................ 17

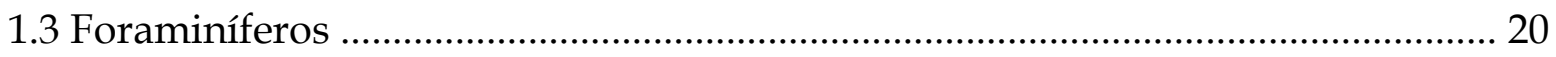

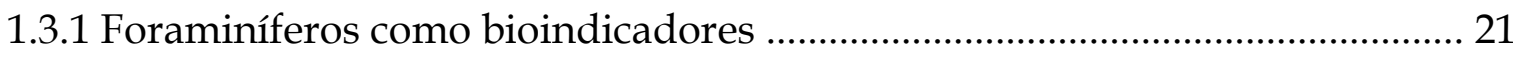

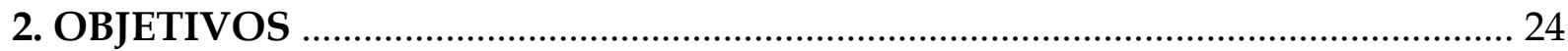

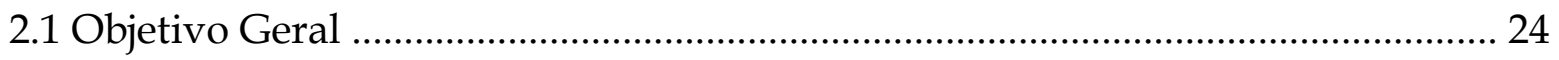

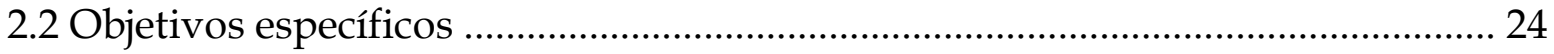

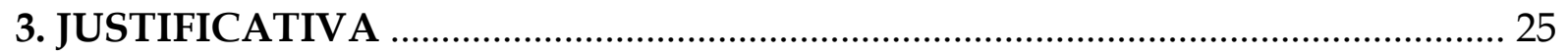

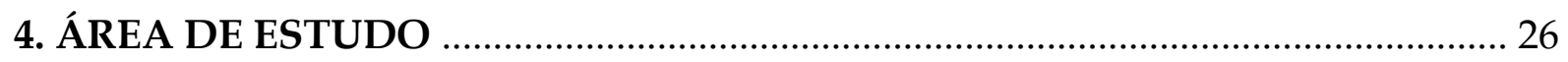

4.1 Município de São Sebastião ...................................................................................... 26

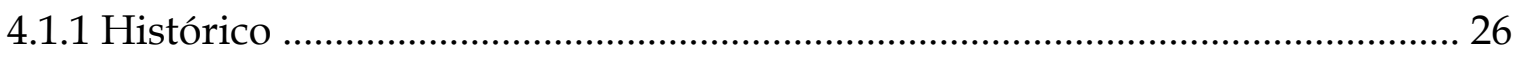

4.1.2 Características ambientais, sócio- econômicas e sanitárias ............................ 27

4.2 Contexto Geológico e caracterização do Canal de São Sebastião ......................... 28

4.3 Praia das Cigarras e descrição do emissário submarino de esgoto ..................... 29

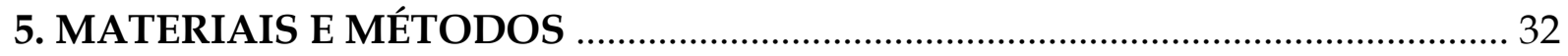

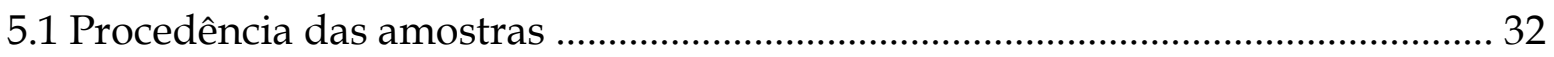

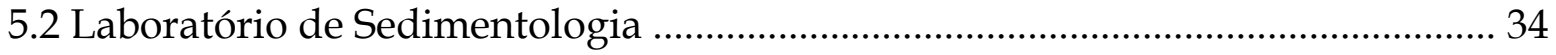

5.3 Laboratório de Preparação das amostras ............................................................ 36

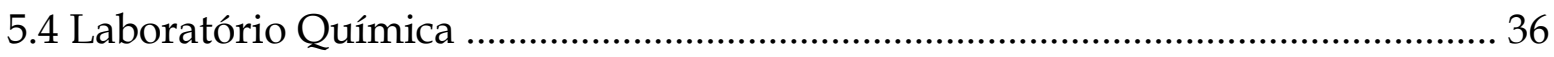

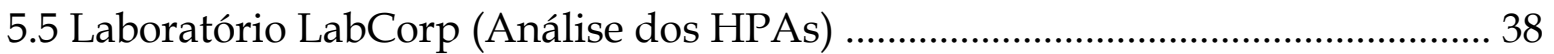

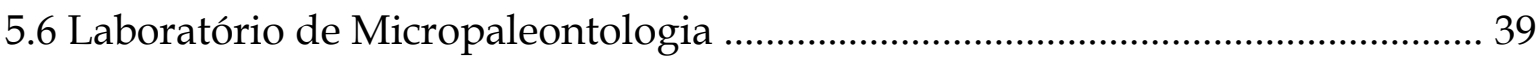

5.7 Laboratório de Miscroscopia Eletrônica (MEV) ................................................... 44 


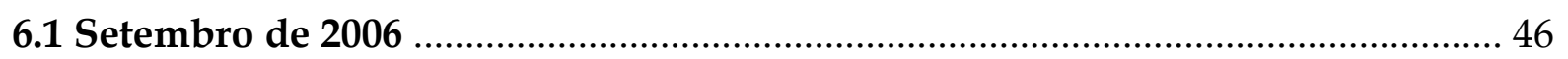

6.1.1 Parâmetros hidrográficos e hidroquímicos ........................................................... 46

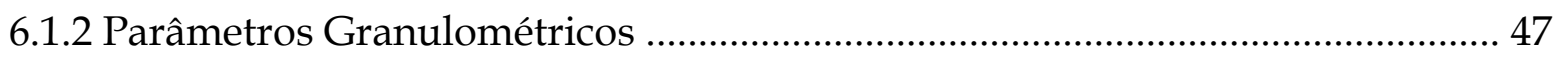

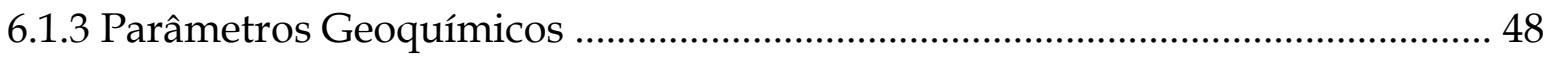

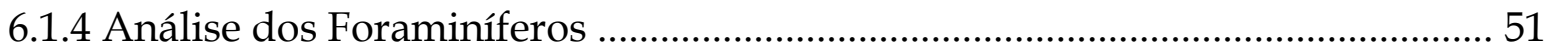

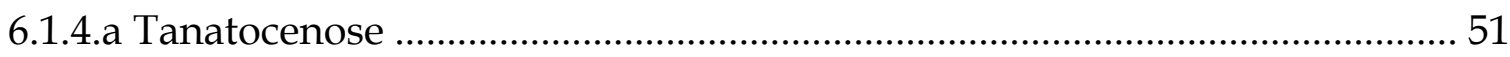

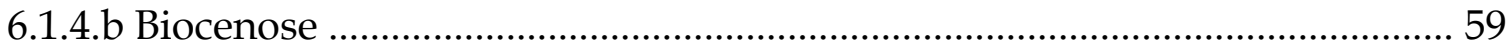

6.1.4. c Comparação entre a Tanatocenose e a Biocenose ...................................... 65

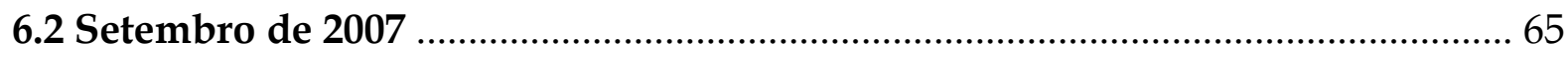

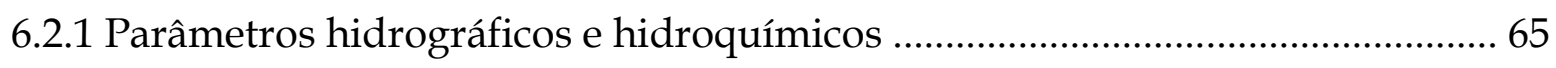

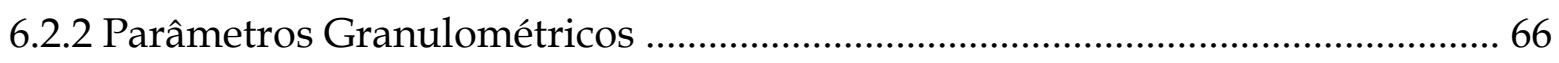

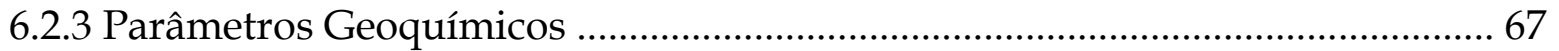

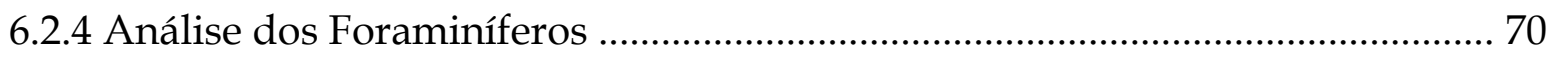

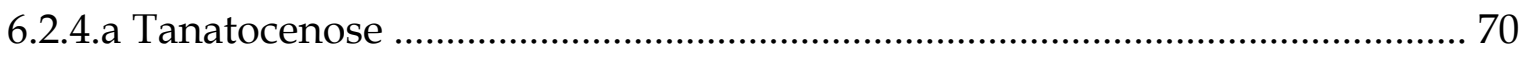

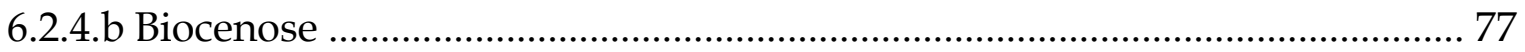

6.2.4.c Comparação entre a biocenose e a tanatocenose de 2007.............................. 84

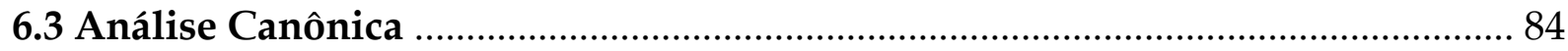

6.3.1 Análise Canônica das tanatocenoses de 2006, 2007 e pontos controles ............ 84

6.3.2 Análise Canônica das biocenoses de 2006, 2007 e pontos controles ................. 86

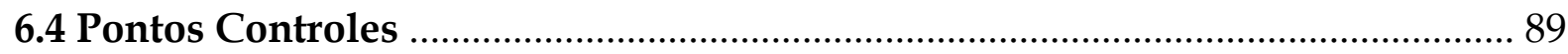

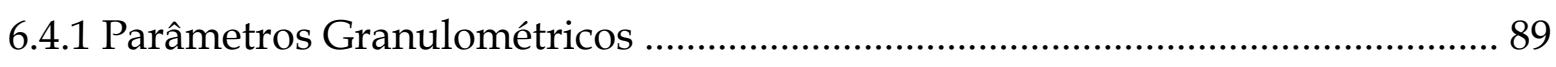

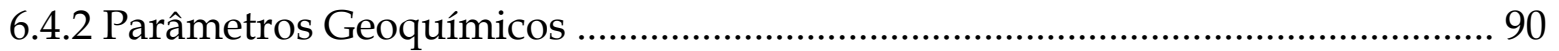

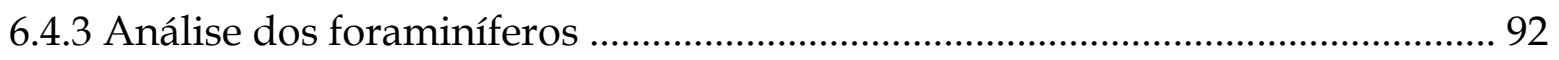

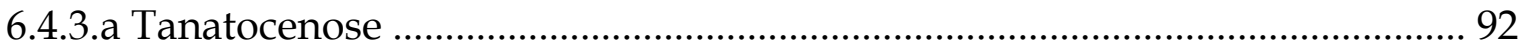

6.4.3.b Comparação com as tanatocenoses de 2006 e 2007 ...................................... 98

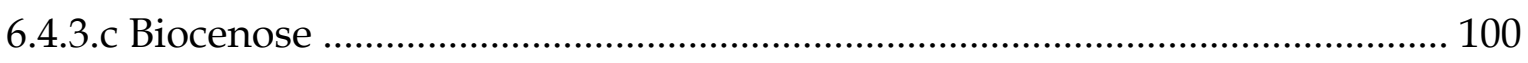

6.4.3.d Comparação da biocenose controle com a tanatocenose controle ............ 104

6.4.3.e Comparação da biocenose controle com as biocenoses de 2006 e 2007 .... 104

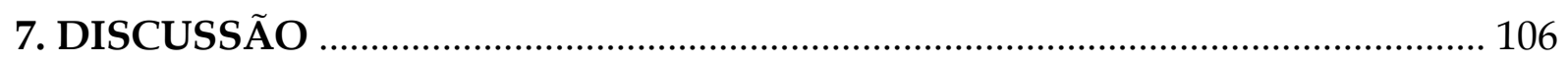

7.1 Parâmetros hidrográficos e hidroquímicos ...................................................... 106 


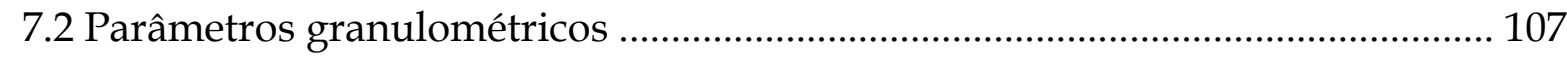

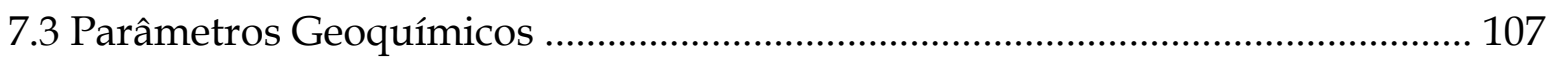

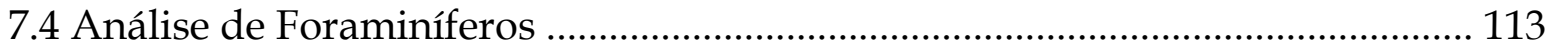

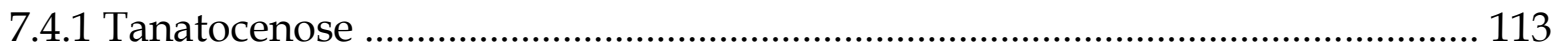

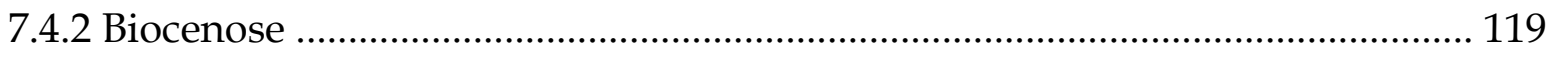

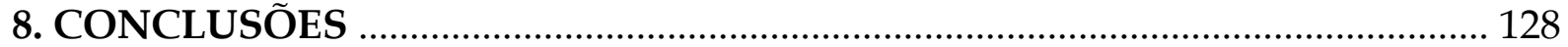

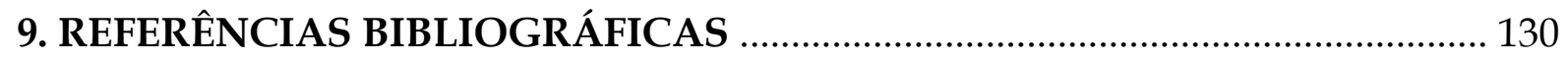

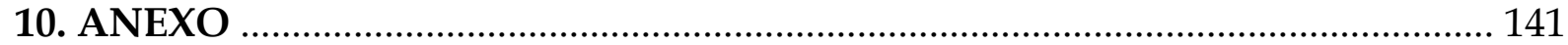




\section{LISTA DE FIGURAS}

Figura 01 - Sistema de disposição de esgoto por emissário submarino ...... 16

Figura 02 - Localização da área de estudo ...................................................... 29

Figura $03 \quad$ - Praia das Cigarras ................................................................. 31

Figura 04 A - Antigo emissário de esgoto ........................................................ 31

Figura 04 B $\quad$ - Estação de pré-condicionamento das Cigarras .......................... 31

Figura $05 \quad$ - Malha amostral círculo crescente da Praia das Cigarras .......... 32

Figura 06 - Localização dos pontos controles ............................................... 33

Figura $07 \quad$ - Fluxograma da análise de granulométrica ................................ 35

Figura 08 A - Moinho de ágata .................................................................... 36

Figura 08 B - Panela de ágata com sedimento ................................................ 36

Figura $08 \mathrm{C} \quad$ - Panela de ágata com sedimento .................................................. 36

Figura 09 - Equipamento LECO® SC-432 …............................................ 38

Figura $10 \quad$ - Sedimento corado com Rosa de bengala ................................... 40

Figura 11 A - Peneiramento a úmido do sedimento ....................................... 41

Figura 11 B - Separação dos foraminíferos dos sedimentos ............................. 41

Figura 12 A ～- Lupa binocular ..................................................................... 41

Figura 12 B - Sedimentos e foraminíferos ........................................................ 41

Figura 12 C - Foraminíferos ................................................................. 41

Figura 12 D - Porta-foraminíferos …............................................................ 41

Figura 13 A - Microscópio eletrônico de varredura (MEV) …............................ 45

Figura 13 B - Stub com fita adesiva de carbono .............................................. 45

Figura 13 C - Stub recoberto por ouro …....................................................... 45

Figura 14 A - Classificação granulométrica de Shepard (1954) de 2006 ......... 48

Figura 14 B - Granulometria de 2006 ............................................................. 48

Figura 15 - Corg, Stotal, Ntotal e razões C/S e C/N dos sedimentos

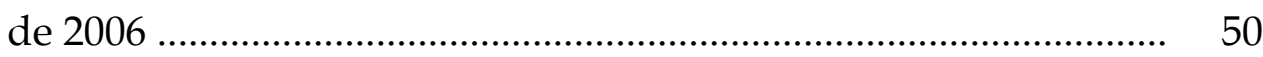

Figura 16 A - Densidade da tanatocenose de 2006 ........................................... 52

Figura 16 B - Riqueza da tanatocenose de 2006 ........................................... 52 
Figura 16 C - Frequência relativa da subordem Rotaliina da tanatocenose de 2006

Figura 16 D - Frequência relativa da subordem Milioliina da tanatocenose de 2006

Figura 16 E - Frequência relativa da subordem Textulariina da tanatocenose de 2006 52

Figura 17 - Morfometria da tanatocenose de 2006 53

Figura 18 - Tafonomia da tanatocenose de 2006 54

Figura 19 - Coloração da tanatocenose de 2006 54

Figura 20 - Frequência relativa dos indicadores de matéria orgânica da tanatocenose de 2006 56

Figura 21 - Frequência dos indicadores de oxigênio da tanatocenose de 2006 57

Figura 22 - Agrupamento modo Q da tanatocenose de 2006 ...................... 58

Figura 23 - Agrupamento modo R da tanatocenose de 2006 ...................... 58

Figura 24 A - Densidade da biocenose de 2006 ............................................... 59

Figura 24 B $\quad$ - Riqueza da biocenose de 2006 ................................................... 59

Figura 24 C - Frequência relativa da subordem Rotaliina da biocenose de 2006

Figura 24 D - Frequência relativa da subordem Milioliina da biocenose de 2006.

Figura 24 E - Frequência relativa da subordem Textulariina da biocenose de 2006 59

Figura 25 - Morfometria da biocenose de 2006 .......................................... 60

Figura 26 - Morfologia da biocenose de 2006 61

Figura 27 - Frequência relativa dos indicadores de matéria orgânica e de oxigênio da biocenose de 2006 63

Figura 28 - Agrupamento modo Q da biocenose de 2006 ............................ 64

Figura 29 - Agrupamento modo R da biocenose de 2006 ............................ 64

Figura 30 - Comparação entre a biocenose e a tanatocenose de 2006 .......... 65

Figura 31 A - Classificação granulométrica de Shepard (1954) de 2007 .......... 67 
Figura 31 B - Granulometria de 2007

Figura 32 - Corg, Stotal, Ntotal, razões C/S e C/N dos sedimentos de 2007

Figura 33 A - Densidade da tanatocenose de 2007 ......................................... 71

Figura 33 B - Riqueza da tanatocenose de 2007 ........................................... 71

Figura 33 C - Frequência relativa da subordem Rotaliina da tanatocenose de 2007

Figura 33 D - Frequência relativa da subordem Milioliina da tanatocenose de 2007

Figura 33 E - Frequência relativa da subordem Textulariina da tanatocenose de 2007 71

Figura 34 - Morfometria da tanatocenose de 2007 72

Figura 35 - Tafonomia da tanatocenose de 2007 73

Figura 36 - Coloração da tanatocenose de 2007 73

Figura 37 - Frequência relativa dos indicadores de matéria orgânica da tanatocenose de 2007

Figura 38 - Frequência relativa dos indicadores de oxigênio da tanatocenose de 2007 76

Figura 39 - Agrupamento modo Q da biocenose de 2007 ........................... 76

Figura 40 - Agrupamento modo R da biocenose de 2007 ............................. 77

Figura 41 A - Densidade da biocenose de 2007 ............................................... 78

Figura 41 B $\quad$ - Riqueza da biocenose de 2007 ................................................. 78

Figura $41 \mathrm{C}$ - Frequência relativa da subordem Rotaliina da biocenose de 2007.

Figura 41 D - Frequência relativa da subordem Milioliina da biocenose de 2007.

Figura 41 E - Frequência relativa da subordem Textulariina da biocenose de 2007 78

Figura $42 \quad$ - Morfometria da biocenose de 2007 ............................................ 79

Figura 43 - Morfologia da biocenose de 2007 .............................................. 80

Figura 44 - Frequência relativa dos indicadores de matéria orgânica da 81 
biocenose de 2007

Figura 45 - Frequência relativa dos indicadores de oxigênio da biocenose de 2007

Figura 46 - Agrupamento modo Q da biocenose de 2007 ........................... 83

Figura $47 \quad$ - Agrupamento modo R da biocenose de 2007 ............................ 83

Figura 48 - Comparação entre a biocenose e a tanatocenose de 2007 .......... 84

Figura 49 - Análise Canônica da tanatocenoses com parâmetros abióticos 85

Figura 50 - Análise Canônica das estações com os parâmetros abióticos ... 86

Figura 51 - Análise Canônica da biocenose com parâmetros abióticos ....... 87

Figura 52 - Análise Canônica das estações com os parâmetros abióticos ... 88

Figura 53 A - Classificação granulométrica de Shepard (1954) dos pontos controles

Figura 53 B - Granulometria dos pontos controles

Figura 54 - Corg, Stotal, Ntotal, razões C/S e C/N dos sedimentos dos pontos controles

Figura 55 A - Densidade da tanatocenose controle ........................................ 93

Figura 55 B - Riqueza dos pontos controles ................................................... 93

Figura 55 C - Frequência relativa da subordem Rotaliina da tanatocenose controle de 2007

Figura 55 D - Frequência relativa da subordem Milioliina da tanatocenose controle de 2007

Figura 55 E - Frequência relativa da subordem Textulariina da tanatocenose controle de 2007 93

Figura 56 - Morfometria da tanatocenose controle ..................................... 94

Figura 57 - Tafonomia da tanatocenose controle ....................................... 94

Figura 58 - Coloração da tanatocenose controle .......................................... 95

Figura 59 - Frequência relativa dos indicadores de matéria orgânica da tanatocenose controle

Figura 60 - Frequência relativa dos indicadores de oxigênio da tanatocenose controle

Figura 61 - ANOVA entre as tanatocenoses de 2006, 2007 e controle 99 
Figura 62 - Principais foraminíferos das tanatocenoses de 2006, 2007 e controle 99

Figura 63 A - Densidade da biocenose controle ............................................... 100

Figura 63 B - Riqueza da biocenose controle ............................................... 100

Figura 63 C - Frequência relativa da subordem Rotaliina da biocenose controle de 2007 ......................................................................... 100

Figura 63 D Frequência relativa da subordem Milioliina da biocenose controle de 2007 100

Figura 63 E - Frequência relativa da subordem Textulariina da biocenose controle de 2007 100

Figura $64 \quad$ - Morfometria da biocenose controle .......................................... 101

Figura 65 - Morfologia da biocenose controle ........................................... 102

Figura 66 - Frequência relativa dos indicadores de matéria orgânica da biocenose controle 103

Figura 67 - Comparação entre a biocenose e a tanatocenose controle ......... 104

Figura 68 - ANOVA entre as biocenoses de 2006, 2007 e controle .............. 105

Figura 69 - Principais foraminíferos das biocenoses de 2006, 2007 e controle 


\section{LISTA DE TABELAS}

Tabela 01 - Dados granulométricos dos sedimentos de 2006 .......................... 47

Tabela 02 - Dados geoquímicos dos sedimentos de 2006 ................................. 48

Tabela 03 - Concentrações dos HPAs e taxas de recuperação dos surrogates

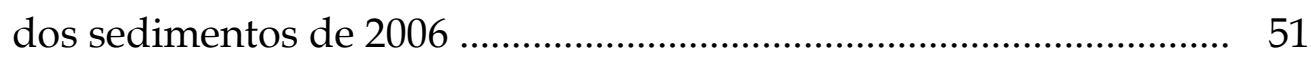

Tabela 04 - Frequência relativa dos indicadores de matéria orgânica e de oxigênio da tanatocenose de 2006 ..................................................... 55

Tabela 05 - Frequência relativa dos indicadores de matéria orgânica e de oxigênio da biocenose de 2006 ........................................................ 62

Tabela 06 - Dados granulométricos dos sedimentos de 2007 ........................... 66

Tabela 07 - Dados geoquímicos dos sedimentos de 2007 .................................. 68

Tabela 08 - Concentrações dos HPAs e taxas de recuperação dos surrogates dos sedimentos de 2007 ............................................................. 70

Tabela 09 - Frequência relativa dos indicadores de matéria orgânica e de oxigênio da tanatocenose de 2007 .................................................... 74

Tabela 10 - Frequência relativa dos indicadores de matéria orgânica e de oxigênio da biocenose de 2007

Tabela 11 - Dados da análise canônica entre as tanatocenoses e os parâmetros abióticos

Tabela 12 - Dados da análise canônica entre as biocenoses e os parâmetros abióticos

Tabela 13 - Dados granulométricos dos pontos controles 89

Tabela 14 - Dados geoquímicos dos pontos controles 90

Tabela 15 - Concentrações dos HPAs e taxas de recuperação dos surrogates dos pontos controles

Tabela 16 - Frequência relativa dos indicadores de matéria orgânica e de oxigênio da tanatocenose dos pontos controles

Tabela 17 - Frequência relativa dos indicadores de matéria orgânica da biocenose dos pontos controles 


\section{LISTA DE ANEXOS}

Anexo 01 - Parâmetros físico-químicos da coluna d'água de 2006

Anexo 02 - Frequência relativa dos foraminíferos mortos e vivos de 2006

Anexo 03 - Parâmetros físico-químicos da coluna d'água de 2007

Anexo 04 - Frequência relativa dos foraminíferos mortos e vivos de 2007

Anexo 05 - Valores de ESQG e PEL para os HPAs

Anexo 06 - Valores dos LCS, brancos do método e taxas de recuperação dos surrogates

Anexo 07 - Frequência relativa dos foraminíferos mortos e vivos dos pontos controles

Anexo 08 - Legenda das pranchas de foraminíferos 


\section{LISTA DE ABREVIATURAS E SIGLAS}

Ag. - Agrupamento

CCME - Canadian Council of Ministers of the Environment

CSS - Canal de São Sebastião

CETESB - Companhia Ambiental do Estado de São Paulo

CONAMA - Conselho Nacional do Meio Ambiente

C org - Carbono orgânico

CTLE - Controle

$\mathrm{E}_{\mathrm{H}^{\prime}}$ Índice de equitatividade de Shannon

EPA - Environment Protection Agency

EPC - Estação de pré-condicionamento

$\mathrm{H}^{\prime}$ - Índice de diversidade de Shannon

HPAs - Hidrocarbonetos Policíclico Aromáticos

ICQGs - Limites de qualidade do sedimento

LCS - laboratory control samples

LQ - Limite de Quantificação

MEV - Microscópio eletrônico de varredura

M.O. - matéria orgânica

MPS - Muito pobremente selecionado

$\mathrm{N}$ total - Nitrogênio total

OD - Oxigênio dissolvido

PEL - Nível provável de efeitos

PS - Pobremente selecionado

SABESP - Companhia de Saneamento do Estado de São Paulo

$S$ total - Enxofre total

TEBAR - Terminal Petrolífero Almirante Barroso

UNT - Unidade Tefelométrica de Turbidez 


\section{RESUMO}

O presente estudo teve por objetivos caracterizar a região circunjacente ao emissário submarino de esgoto das Cigarras, São Sebastião, SP, e avaliar a influência dos esgotos por ele disposto na qualidade dos sedimentos locais e sobre as associações de foraminíferos bentônicos. Para atingir tal objetivo, foram analisadas 20 amostras coletadas ao redor do emissário submarino, em Setembro de 2006 e 2007, sendo mais duas amostras (pontos controles) coletadas distantes da área de influência do emissário, porém no canal de São Sebastião. Em cada estação foram analisados parâmetros físico-químicos da coluna d'água, a granulometria, a geoquímica e o conteúdo microfaunístico dos sedimentos. Foraminíferos vivos e mortos foram analisados separadamente, sendo posteriormente realizados estudos taxonômicos, morfológicos, tafonômicos e estatísticos. Com relação às análises realizadas na coluna d'água, apenas o parâmetro oxigênio dissolvido, da maioria dos pontos analisados em 2006, apresentou valor abaixo do limite de referência estipulado pelo CONAMA. De acordo com os resultados granulométricos, os sedimentos da área de estudo são classificados como arenolamosos, o que permite inferir circulação de fundo fraca a moderada. As estações com maiores concentrações de lama são as que apresentaram maiores teores de carbono orgânico, nitrogênio e enxofre. No tocante as concentrações de HPAs, de modo geral, os valores são considerados baixos, i.e. inferiores a $5 \mu \mathrm{g} . \mathrm{kg}^{-1}$. Análises composicionais e morfológicas revelaram diferenças significativas entre as tanatocenoses e as biocenoses identificadas próximo ao emissário. Nas tanatocenoses observou-se dominância da espécie oportunista Ammonia tepida, sendo também observada significativa abundância de Pararotalia cananeiaensis e Cribroelphidium spp. Nas biocenoses, em contrapartida, apesar de Ammonia tepida ser dominante, as espécies que apresentaram maior abundância são indicadoras de ambiente rico em matéria orgânica, tais como Brizalina stritula e Bolivina spp. As tanatocenoses são constituídas por carapaças médias e pequenas, parcialmente fragmentadas, com poucos indivíduos piritizados, limonitizados ou preenchidos por monossulfeto de ferro. Já nas biocenoses, as carapaças são médias, pequenas e sem alteração de cor. Com relação aos pontos controles, Pararotalia cananeiaensis e Ammonia tepida são as espécies dominantes nas tanatocenoses e biocenoses, respectivamente. Observou-se, nestes pontos, maior abundância, riqueza e diversidade, o 
que possivelmente está associado à localidade na qual os mesmos foram amostrados, ou seja, distantes da saída do emissário e com menor susceptibilidade à influência do esgoto por ele disposto. Por meio dos resultados das análises taxonômicas e estatísticas, concluiuse que os foraminíferos mortos não podem ser utilizados em estudos de monitoramento ambiental, uma vez que não representam com fidelidade a associação viva do local amostrado. A partir dos dados granulométricos, geoquímicos e das biocenoses conclui-se que a região sofre enriquecimento orgânico nos sedimentos, afetando negativamente a abundância e a diversidade das associações de foraminíferos bentônicos.

Palavras-chaves: canal de São Sebastião, praia das Cigarras, emissário submarino, esgoto doméstico, foraminíferos, hidrocarbonetos policíclicos aromáticos. 


\section{ABSTRACT}

The influence of submarine outfall of domestic sewage on the benthic foraminifera and sediments quality at Cigarras, São Sebastião, SP, is evaluated in this dissertation. Twenty water and bottom sediment samples were collected around the outfall in September 2006 (ten samples) and 2007 (ten samples). Another two samples were collected in the São Sebastião Channel far from the domestic sewage disposal as controls. For each water sample physicochemical analyses were carried out. In the sediments, grain size, geochemistry and foraminifera composition were analyzed. The taxonomy, morphology, taphonomy and statistics of live and dead foraminifera were analyzed separately. Water sample water column analyses showed that only dissolved oxygen was below CONAMA reference levels at the majority of sites sampled in 2006. The area is characterized by sandmud sediments, with weak to moderate bottom circulation. Samples with the highest mud percentages also have the highest concentrations of organic carbon, sulphur and nitrogen. HPA values are low, less than $5 \mu \mathrm{g} \mathrm{Kg}^{-1}$ in most samples. There are significant compositional and morphological differences between thanatocenoses and biocenoses near the outfall. The opportunistic species Ammonia tepida, Pararotalia cananeiaensis and Cribroelphidium spp. dominate the death assemblages. Although A. tepida is the dominant species in the living assemblages, indicators of organic matterial, such as Brizalina striatula e Bolivina ssp. are abundant. The thanatocenoses are represented by partially fragmented medium and small tests, with few tests pyritized, limonitized or filled with iron monossulfate. Tests in the biocenoses are medium to small, without any alteration of color. The controls are made up mainly by Pararotalia cananeiaensis among the dead organism, and by Ammonia tepida among the living. Foraminifera at these control sites are more abundant, richer and more diverse than near the outfall. This is interpreted as due to their distance from the influence of the sewage disposal around the outfall diffusers. The results of this study suggest that thanatocenoses cannot be used in environment studies, because they do not faithfully represent the local living assemblage. The analyses of grain size-geochemistry and the biocenoses show that the area is undergoing organic enrichment from domestic sewage outfall, with negative effects on the abundance and diversity of living benthic foraminiferal assemblages. 
Key words: São Sebastião Channel, Cigarras Beach, submarine outfall, domestic sewage, foraminifera, polycyclic aromatic hydrocarbons. 


\section{INTRODUÇÃO}

\subsection{Emissário submarino de esgoto}

As águas costeiras do estado de São Paulo são suscetíveis a poluição por esgotos sanitários, derramamentos de petróleo e efluentes industriais. Os esgotos sanitários são os mais comuns e ocorrem em todas as regiões litorâneas (Lamparelli, 2006), devendo ser tratados como preocupação de saúde pública, já que acarretam problemas para a população (Weber, 1992), como as doenças de veiculação hídrica causadas por bactérias (febre tifóide, cólera e diarréias), vírus (gastroenterites, hepatite A e E), protozoários (amebíase, giardíase e criptosporidíase) e helmintos (esquistossomose e ascaridíase) (CETESB, 2008).

Desta maneira, um dos maiores desafios das regiões costeiras de todo o planeta têm sido como gerenciar o aumento exponencial dos esgotos sanitários e industriais. No Brasil, a degradação ambiental em regiões costeiras ocorre sistematicamente, há diversas décadas, em decorrência da falta de uma política de planejamento de ocupação urbana no litoral. Assim, ocupações em áreas de proteção ambiental, loteamentos clandestinos e aporte de cargas industriais e difusas aumentam a quantidade de cargas poluidoras em estuários, baías e praias (Marcellino, 2000).

Muitos municípios litorâneos apresentam alta densidade demográfica, notadamente em épocas de veraneio, quando a quantidade de esgoto doméstico na região aumenta consideravelmente. A maioria desses locais apresenta rede coletora e de tratamento de esgoto incipientes, acarretando despejos domésticos ao mar de forma pontual (emissários submarinos de esgoto) ou difusa (cursos de água) (Lamparelli, 2006).

Assim, muitos municípios litorâneos recorrem ao uso de emissários submarinos, visando minimizar a problemática gerada pelo esgoto doméstico. Para Yang et al (2000), a disposição oceânica é a maneira mais original e acessível de se tratar os esgotos gerados pelo homem, devido à sua conveniência e viabilidade financeira.

Quando bem projetados e associados a tratamentos secundários, os emissários submarinos representam a remoção segura de contaminantes da região costeira (Werme e Hunt, 2004). Contudo, quando os efluentes são lançados apenas com pré-condicionamento 
e, dependendo da resilência do meio, os emissários submarinos podem se tornar focos de poluição (Teodoro, 2006).

Isto ocorre porque as estações de pré-condicionamento (EPC) não retiram dos efluentes os nutrientes, óleos, graxas e diversos outros contaminantes tóxicos, como metais pesados, bifenilas policloradas (PCBs), pesticidas, surfactantes, fenóis e hidrocarbonetos aromáticos policíclicos (HPAs) (Werme \& Hunt, 2004).

Assim, se a implantação e a operação do emissário submarino não forem adequadas, o mesmo pode impactar negativamente o ecossistema marinho, tornando-o suscetível a alterações quantitativas e qualitativas do bento, do plâncton e da ictiofauna local (Marcellino e Macedo, 2006).

A eutrofização, causada por despejos de esgoto no meio marinho, consiste em um dos impactos negativos e têm ocorrido em muitas regiões costeiras mundiais, especialmente nas localizadas próximas a grandes centros urbanos (Montone e Bícego, 2008). Segundo Weber (1992), os esgotos constituem o maior problema de poluição global em volume de poluentes despejados e problemas de saúde acarretados.

Assim, apesar de os emissários submarinos de esgoto serem uma alternativa mais viável financeiramente do que outros tratamentos, na maioria das vezes não levam em conta que o poder de dissolução dos oceanos é finito, principalmente em áreas costeiras abrigadas, onde normalmente são lançados os esgotos (Montone e Bícego, 2008). Além disso, ainda não se sabe se a introdução antrópica de substâncias nos oceanos está alterando os ciclos biogeoquímicos e a biota marinha de forma irreversível (Weber, 1992).

Portanto, a opção pela implantação de um emissário submarino de esgoto deve ser precedida por análise e comparação com outras metodologias. Também deve ser avaliada a viabilidade técnica, econômica e ambiental do local de implantação, já que algumas regiões são menos favoráveis do que outras, devido à baixa capacidade de diluição e de transporte, interesse comercial ou grande importância biológica (Marcellino e Macedo, 2006).

Caso opte-se pelo uso de emissário, estudos e monitoramentos devem ser realizados, visando avaliar possíveis impactos ambientais causados pela introdução pontual de material antropogênico, principalmente em regiões rasas da zona costeira, onde a circulação local não proporciona diluição infinita (Weber, 1992). 
O esgoto sanitário é constituído por águas coletadas de residências, de comércios, de instituições e algumas vezes de indústrias. Sua composição média consiste de 99,9\% de água e somente $0,1 \%$ de sólidos, sendo que 75\% desses correspondem à matéria orgânica em decomposição. Nesses sólidos proliferam-se microorganismos, podendo ocorrer formas patogênicas provenientes das fezes de pessoas doentes (Nuovolari, 2003).

No Brasil, antes de ser lançado ao mar, o efluente é encaminhado para uma EPC, sendo submetido apenas a pré-tratamento, ou seja, remoção de sólidos grossos e de material em suspensão através de gradeamento, com posterior desinfecção química com cloro (Lamparelli, 2006).

O gradeamento visa reter os sólidos flutuantes, como plástico, madeira, óleo e graxas, que tendem a se agrupar na superfície da pluma, tendo seu deslocamento influenciado pelos ventos. Os óleos e as graxas são menos densos e imiscíveis em água e devido à sua tendência de flutuar, podem formar manchas na superfície quando agregados (Agudo et al., 1986).

Os métodos de desinfecção foram utilizados primeiramente em águas destinadas à ingestão, e posteriormente em efluentes domésticos (Acher et al., 1997). Os processos químicos de desinfecção baseiam-se no potencial de oxidação do desinfetante de danificar a parede celular dos microorganismos, matando-os. Entre os desinfetantes químicos, o Cloro é um dos mais usados devido à sua efetividade e acesso econômico. No entanto, essa substância é extremamente perigosa, podendo produzir compostos orgânicos halogênicos que contaminam o ambiente marinho através do tratamento dos efluentes. Pesquisas identificaram que alguns desses halogênios são tóxicos e/ou potencialmente cancerígenos tanto para o homem quanto para a vida aquática (Acher et al., 1997). Visando não prejudicar a microbiota auxiliadora da purificação da água, há países que descloram o efluente antes de realizar sua disposição ao mar, fato este que não ocorre no Brasil (Marcellino, 2000).

Após o pré-tratamento, o esgoto é enviado para o emissário submarino (tubulação fixa ao fundo marinho) e em sua porção final há difusores (orifícios) calculadamente espaçados, que determinam a vazão do efluente para permitir sua correta diluição inicial (Lamparelli, 2006; Marcellino, 2000). O local onde ocorre essa diluição é designado como zona de mistura (Marcellino e Macedo, 2006) (Fig. 01). 


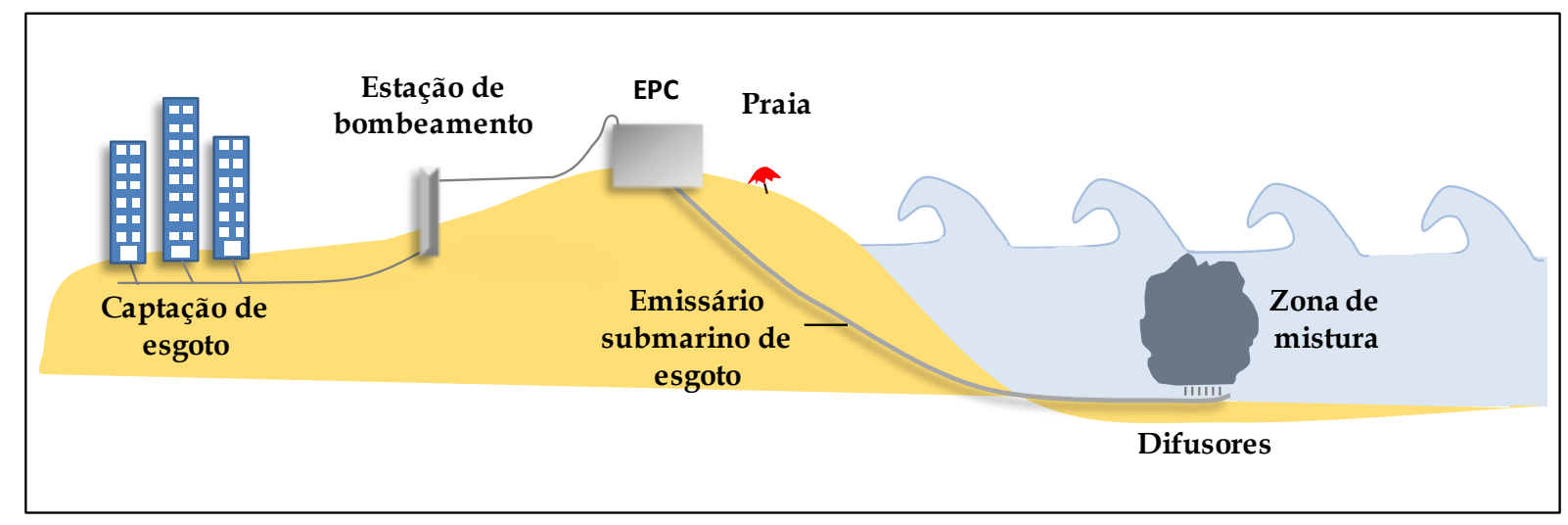

Figura 01: Esquema de sistema de disposição de efluentes através de emissário submarino de esgoto (modificada de CETESB, 2005).

As partículas provenientes do esgoto vão se misturando com a massa de água, promovendo redução na concentração dos poluentes. Se não houver termoclima no local do difusor, o campo do esgoto chegará à superfície, completando o processo de diluição inicial, graças à diferença de densidade. Porém, se ocorrer mudança brusca de densidade entre o corpo receptor de água e o efluente, a mistura entre eles poderá ser mais densa que a água superficial, formando pluma submersa (Chao e Motta Pacheco, 1979). Essa última situação é mais favorável, já que evita a formação de manchas superficiais (Ludwing, 1977).

Após a diluição inicial, a pluma é transportada pelas correntes oceânicas para além da zona de mistura, sofrendo diluição horizontal, sendo ela inferior a inicial. Simultaneamente às diluições ocorre o processo de decaimento bacteriano, caracterizado pela redução de organismos contaminantes presentes no esgoto. A taxa de decaimento bacteriano (T90) é o tempo necessário para que os coliformes sejam reduzidos em 90\% (Ludwing, 1977). Ela é influenciada pela temperatura e salinidade da água, assim como pela falta de nutrientes vitais para a manutenção da vida desses microorganismos. Outro processo que faz parte do tratamento do efluente é a sedimentação, que consiste basicamente na deposição das partículas sólidas do esgoto ao longo do leito marinho (Marcellino, 2000).

Na elaboração do projeto de um emissário submarino de esgoto, sua extensão total e do trecho difusor deve ser estabelecida para gerar suficiente diluição, dispersão e 
decaimento bacteriano do efluente, possibilitando concentrações de coliformes fecais aceitáveis para a qualidade ambiental nas áreas de banho. Difusores de pequenos diâmetros e próximos proporcionam maior diluição inicial, porém, em esgotos não tratados (como o das Cigarras), o diâmetro recomendado é superior a $15 \mathrm{~cm}$ para evitar entupimentos (Ludwing, 1977).

O material utilizado na construção do emissário deve ser resistente à corrosão, a vazamentos e ser capaz de manter sua integridade (Chao e Motta Pacheco, 1979). Atualmente utilizam-se materiais plásticos como PEAD (polietileno de alta densidade), PVC (cloreto de polivinil) e PPE (polipropileno), assim como tubos de aço revestidos de concreto.

\subsection{Hidrocarbonetos Policíclicos Aromáticos (HPAs)}

Ambientes marinhos e estuarinos vêem sendo impactados há décadas por despejos de resíduos antrópicos. Os contaminantes entram nesses ambientes através de muitas vias, como por despejos de efluentes provenientes da comunidade costeira e de navios, rios, deposição atmosférica, águas pluviais continentais e vazamentos acidentais de petróleo (Kennish, 1992).

Os hidrocarbonetos são considerados um dos principais grupos de poluentes do meio marinho, principalmente devido ao caráter tóxico e refratário de muitos dos seus compostos (Medeiros, 2000). As principais classes de hidrocarbonetos utilizadas em estudos de sedimentos marinhos são: n-alcanos, alcanos isoprenóides, biomarcadores de petróleo (hopanos, terpanos e esteranos), alquil-benzenos lineares (LABs) e os policíclicos aromáticos (HPAs) (Medeiros, 2000).

Os HPAs são constituídos por átomos de hidrogênio e carbono, sendo formados por 2 ou mais anéis benzênicos unidos. A análise de HPAs em estudos decorre de sua ação tóxica sobre a biota marinha e o homem (Medeiros, 2000). Alguns tipos além de serem carcinogênicos e mutagênicos também se acumulam na cadeia trófica (Basheer et al., 2003).

A maior parte do óleo que penetra no mar (45\%) é proveniente de águas de escoamentos urbanos, efluentes municipais e de indústrias não petrolíferas, assim como de 
rios poluídos. Cerca de $35 \%$ do óleo é originário do seu transporte, sendo que dessa porcentagem, aproximadamente $25 \%$ são geradas por vazamentos acidentais. Os outros 20\% restantes são provenientes de fontes oceânicas naturais (Abel, 1989 apud Kennish, 1992).

Esses compostos são oriundos primariamente de fontes antrópicas, como queima de combustíveis fósseis e de seus derivados, descarte de resíduos oleosos no ambiente, derrames acidentais de petróleo e descarte de efluentes nos oceanos. Em menor quantidade são originados naturalmente pela combustão da biomassa vegetal, assim como pela diagênese de precursores naturais (pigmentos e compostos diterpenóides e triterpenóides de vegetais) (Law e Biscaya, 1994).

Os HPAs são poluentes ubíquos que podem ser detectados nas mais diferentes matrizes ambientais, bióticas e abióticas (Harrad, 2000). Apesar de nem todos esses compostos serem perigosos, os de baixo peso molecular, como o antraceno, fluoreno, naftaleno e fenantreno, são sempre altamente tóxicos e geram efeitos adversos nos organismos, porém sem causar câncer. Já os de alto peso molecular, como o benzo(c)fenantreno, benzo(a)pireno e dibenzo(a, I) pireno, são carcinogênicos, mutagênicos ou teratogênicos (Mekenyan et al., 1994 apud Ernst et al., 2006).

Há mais de 100 tipos de HPAs, porém apenas 16 são considerados poluentes prioritários pela Agência de Proteção Ambiental dos Estados Unidos (EPA), baseado na sua ocorrência e potencial carcinogênico. O mais conhecido e comum é o Benzo(a)pireno (BAP), que contém cinco anéis de benzeno condensados, sendo resultante da combustão incompleta de combustíveis fósseis, matéria orgânica e madeira.

Os HPAs presentes nos sedimentos podem ser acumulados nos organismos vivos que vivem no ou sobre os sedimentos, fazendo com que esses compostos retornem à cadeia alimentar, porém sem ocorrência de biomagnificação. Esses compostos são prontamente metabolizados, por peixes e alguns invertebrados, em metabólitos excretáveis. Moluscos e crustáceos possuem processos metabólicos menos eficientes para os HPAs, e acabam acumulando essas substâncias (Law e Biscaya, 1994).

Esses compostos são ativados em organismos dotados da atividade enzimática MFO (mixed function oxygenase) no fígado, rins e/ou guelras. Invertebrados apresentam baixa capacidade de metabolizar HPAs, já que a MFO está presente apenas em anelídeos e 
artrópodos. No entanto, animais que não possuem esse sistema enzimático, como é o caso dos foraminíferos, podem acumular grandes quantidades desses hidrocarbonetos em seu citoplasma, principalmente por se alimentarem de forma diversificada (matéria orgânica particulada, detrito) que são facilmente afetadas pela poluição (Kennish, 1992).

Os contaminantes que entram no sistema marinho e estuarino podem ser tóxicos para muitos organismos, já que podem ser acumulados em concentrações muito maiores do que a encontrada na água. A bioacumulação de poluentes nos tecidos de organismos aquáticos tem sido muito utilizada para determinar o grau de contaminação das águas. Toxicologistas utilizam dois termos para descrever esse processo. A bioconcentração refere-se à habilidade do organismo em acumular o contaminante em excesso quando comparado a concentração do mesmo na água. Já o termo biomagnificação refere-se à concentração do poluente ao longo da cadeia trófica, onde baixos níveis se concentram nos organismos da base da cadeia, enquanto que quantidades maiores acumulam-se nos organismos de topo, podendo chegar a doses prejudiciais e até mesmo letais. Assim, algumas substâncias podem ter efeito de bioconcentração, porém não necessariamente de biomagnificação. Poluentes lipofílicos e que possuem baixa solubilidade tendem a ter grande potencial de biomagnificação (Wilson, 1988 apud Kennish, 1992).

A maioria dos foraminíferos bentônicos pertence à infauna e vivem em águas rasas a profundas, podendo habitar ambientes anóxicos onde os HPAs são degradados lentamente e podem persistir por longo tempo (Kennish, 1992). Os impactos gerados pelo óleo são mais sentidos pelos foraminíferos localizados próximos ou na interface entre a superfície do sedimento marinho e a água. O petróleo proveniente de derrames pode alcançar o sedimento e causar condições anóxicas que por si só já são suficientes para provavelmente matar a maioria dos organismos, incluindo os foraminíferos (Ernst et al., 2006).

Efluentes industriais e esgotos domésticos contêm altas concentrações de HPAs particulados e solúveis, e juntos com o escoamento superficial do solo e a deposição do ar, representam as principais fontes desses compostos de elevadas massas moleculares para o ambiente aquático (Basheer et al., 2003), onde tendem a depositar-se nos sedimentos, ficando disponíveis para a fauna da região (Medeiros, 2000). 
Assim, muitos estudos têm investigado a origem, distribuição e o comportamento dos hidrocarbonetos na coluna d’água (Zanardi et al., 1999a, Zanardi et al., 1999), nos sedimentos (Zanardi et al., 1999a, Medeiros e Bícego, 2004; Readman et al., 2002) e nos organismos marinhos (Valerio et al., 2000; Silva et al., 2006; Barbour et al., 2008).

\subsection{Foraminíferos}

Segundo a classificação sistemática proposta por Loeblich e Tappan (1988), os foraminíferos pertencem ao Reino Protista, Filo Granuloreticulosa, Classe Rhizopoda e Ordem Foraminifera. Dentro dessa Ordem, os autores descrevem 12 subordens, sendo as mais importantes a Textulariina (aglutinantes), Rotaliina (hialinos) e Miliolina (porcelanáceos).

Os foraminíferos apresentam protoplasma granuloso protegido por uma carapaça (teca ou testa) (Loeblich e Tappan, 1988; Lipps, 1993). Seus pseudópodes delgados, anastomosados e granoreticulares se projetam para fora da testa para alimentação e locomoção (Lipps, 1993).

As tecas podem ser orgânicas, aglutinantes ou de minerais secretados (calcita, aragonita ou sílica). As orgânicas são constituídas predominantemente de mucopolissacarídeos. Já as aglutinantes, além das paredes de mucopolissacarídeo, incorporam partículas sedimentares (e.g., grãos de quartzo, espículas de esponjas, outras testas de foraminíferos). As calcárias são constituídas por cristais de aragonita ou de calcita, e dependendo do arranjo dos cristais, as testas podem ser translúcidas (hialinas) ou opacas (porcelanáceas) (Boersma, 1978; Lipps, 1993).

A carapaça é constituída de uma ou mais câmaras, de diferentes formatos e arranjos, conectadas entre si por um orifício, o forâmen (Boersma, 1978), que possibilita que o protoplasma ocupe todas as câmaras (Lipps, 1993). A abertura da carapaça varia de tamanho e forma, porém geralmente acompanha o formato da câmara na qual encontrase inserida (Boersma, 1978).

A maioria dos hialinos e alguns aglutinantes possuem poros em sua carapaça, para a realização de trocas gasosas (Loeblich e Tappan, 1964), sendo seu tamanho, forma e distribuição variáveis (Boersma, 1978). 
Os foraminíferos são em sua maioria marinhos, mas há representantes de água doce e salobra (Cushman, 1950; Loeblich e Tappan, 1964). Esses organismos ocorrem em todas as latitudes (Loeblich e Tappan, 1964), sendo encontrados desde os pólos até regiões tropicais, desde a região de entre-marés até abissais (Lipps, 1993). Os foraminíferos podem ser bentônicos ou planctônicos.

Os bentônicos surgiram há 550 milhões de anos, distribuindo-se, portanto, desde o Cambriano até os dias atuais (Loeblich e Tappan, 1964; Boersma, 1978). Seus representantes pertencem a infauna, vivendo entre os grãos do sedimento e ao longo da coluna sedimentar, e epifauna, aderidos permanente ou temporariamente a substratos (Loeblich e Tappan, 1964).

Já os foraminíferos planctônicos surgiram no Jurássico, há 190 milhões de anos, tornando-se mais abundante a partir do Cretáceo. Geralmente vivem em ambientes marinhos de águas limpas, oceânicas e sem material em suspensão, evitando águas costeiras e rasas. (Debenay et al., 1996).

\subsubsection{Foraminíferos como bioindicadores}

Em áreas poluídas, as análises físico-químicas são determinadas prioritariamente por métodos analíticos (Burone et al., 2006). Porém, é difícil detectar uma mudança ou avaliar o impacto de um ambiente a partir apenas dessas análises (Goodsell et al., 2009). Por isto, muitos reconheceram que o uso de seres vivos para avaliar o impacto e a poluição de um ambiente é mais importante que os fatores físico-químicos do mesmo (Goodsell et al., 2009). Dessa maneira, os foraminíferos estão entre os organismos bentônicos mais utilizados como bioindicadores para avaliar efeitos antrópicos no ambiente (Burone et al., 2006).

Na década de 60 iniciaram-se estudos sobre os efeitos da poluição nos foraminíferos bentônicos e seu possível uso como organismos indicadores. Desde então, a utilização desses organismos como bioindicadores têm crescido, especialmente em locais poluídos (Leorri et al., 2008).

Ao longo dos anos, foram realizados estudos utilizando os foraminíferos em locais poluídos por emissários submarinos de esgoto (Zalesny, 1959; Bandy et al., 1964a, 1964; 
Schafer, 1973; Teodoro, 2006; Mojtahid et al., 2008; Hyams-Haphzan et al., 2009; Teodoro et al., 2009), por metais pesados (Leorri et al., 2008; Frontalini et al., 2009) e por hidrocarbonetos de petróleo (Morvan et al., 2004; Ernst et al., 2006; Sabean et al., 2009).

Os foraminíferos bentônicos são excelentes indicadores e estão entre os protozoários mais abundantes e conspícuos dos ambientes costeiros e marinhos (Ernst et al., 2006). Esses organismos são muito sensíveis às variáveis físicas (temperatura, luz, corrente), químicas (salinidade, alcalinidade, densidade) e biológicas (nutrientes e simbiose) do meio em que vivem. Assim, qualquer variação ambiental pode alterar a composição das associações (Boersma, 1978; Scott et al., 2001).

Isso se deve pelo fato das populações desses organismos serem dinâmicas e responderem a inúmeros estresses naturais e antrópicos. Devido ao seu curto ciclo de vida e específicos habitats, eles respondem rapidamente às mudanças ambientais (Ernst et al., 2006), adaptando-se às novas condições, ou migrando para nichos compatíveis com suas exigências ambientais (Schafer, 1973). Como a taxa de biodisponibilidade dos compostos tóxicos não pode ser analisada diretamente dos sedimento ou da água, o estudos desses organismos fornece informações sobre os efeitos da poluição (Ernst et al., 2006).

Os foraminíferos respondem tanto a variações ambientais naturais, como salinidade e temperatura, quanto a alterações antropogênicas, como poluição, eutrofização e hipóxia. As respostas dadas às condições adversas do meio consistem em alterações na abundância e diversidade, assim como anormalidades nas carapaças (Leorri et al., 2008; Burone et al., 2006).

Além de serem sensíveis, de tamanho reduzido, apresentarem boa preservação da carapaça no sedimento e serem cosmopolitas (Loeblich e Tappan, 1964), esses organismos são fáceis de coletar, proporcionam análises a baixo custo e permitem análises estatísticas adequadas, já que eles são normalmente encontrados em abundância (Bandy et al., 1964; Leorri et al., 2008).

Além disso, os foraminíferos ocupam importante posição nas cadeias alimentares marinhas e nos ciclos biogeoquímicos (Lee e Capriulo, 1991), devido à sua habilidade em assimilar energia dos diminutos organismos autotróficos ou da matéria orgânica degradada, transformando-a, posteriormente, em alimentos para os consumidores secundários (Lipps e Valentine, 1970). Esta habilidade advém das várias estratégias 
tróficas, que os foraminíferos utilizam para obter os nutrientes necessários ao seu crescimento e período reprodutivo (Lipps, 1993).

Como os foraminíferos assimilam a matéria orgânica do meio e outros compostos químicos, isso se reflete posteriormente na sua morfologia e na composição de suas associações. Portanto, em ambientes impactados há geralmente a predominância de espécies oportunistas, que são mais resistentes aos poluentes (Duleba et al., 2005). 


\section{OBJETIVOS}

\subsection{Objetivo geral}

Realizar caracterização geoambiental da região circunjacente aos difusores do emissário submarino das Cigarras, São Sebastião, SP, durante o mês de Setembro de 2006 e de 2007, avaliando qualitativamente, a influência dos efluentes sob as associações de foraminíferos bentônicos.

\subsection{Objetivos específicos}

1) Determinar as características composicionais e texturais dos sedimentos;

2) Determinar a concentração dos 16 principais congêneres de hidrocarbonetos aromáticos policíclicos (HPAs) dos sedimentos;

3) Analisar as concentrações de $C, N, S$ do sedimento, calculando as razões $C / N$ e $C / S$ para verificar a origem da matéria orgânica e o potencial oxi-redutor dos sedimentos;

5) Analisar a composição faunística das associações de foraminíferos mortos e vivos, bem como sua variação espacial e temporal em relação aos parâmetros hidrográficos, sedimentológicos e geoquímicos obtidos em Setembro de 2006 e 2007 e nos pontos controles;

6) Verificar a validade do uso da tanatocenose como bioindicador de ambientes impactados. 


\section{JUSTIFICATIVA}

O projeto forneceu dados e interpretações biogeoquímicas e hidroquímicas inéditas, quanto a influência da descarga de efluentes domésticos na área circunjacente aos difusores do emissário submarino de esgoto das Cigarras, com relação à qualidade dos sedimentos no tocante das concentrações de nutrientes $(C, N)$, S e HPAs, permitindo tecer várias considerações sobre os possíveis efeitos às associações de foraminíferos, que foram utilizados como bioindicadores. 


\section{4. ÁREA DE ESTUDO}

\subsection{Município de São Sebastião}

\subsubsection{Histórico}

Inicialmente, a região do município de São Sebastião era ocupada pelos índios Tupinambás. Porém, em 20 de janeiro de 1502, a ilha de São Sebastião (Ilha Bela) foi descoberta por Américo Vespúcio, que lhe nomeou segundo o nome do Santo do dia, São Sebastião. Com a colonização portuguesa da região, no início do século XVII, os primeiros habitantes desta faixa litorânea eram constituídos por famílias vindas de Santos. Foram formados dois povoados distintos: Villa Bella da Princesa, localizado na ilha, e São Sebastião, situado no continente (IBGE).

A economia da região era baseada na produção agrícola concentrada ao redor do porto de São Sebastião. No século XVII a Vila de São Sebastião teve um crescimento econômico, devido à instalação de uma armação para pesca de baleias e fábricas de seus derivados, assim como pela expansão da produção de açúcar e aguardente. Também constituiu-se porto terminal de uma rota de contrabando de ouro que saía de Minas Gerais, atravessava o vale do Paraíba, a Serra do Mar, e chegava ao litoral norte Paulista para fazer conexão com a África (IBGE).

No século XIX, com a expansão da cafeicultura, São Sebastião consolidou-se como um dois mais prósperos centros da Província, constituindo-se porto de escoamento da produção do norte de São Paulo e do sul de Minas Gerais para Santos e Rio de Janeiro (IBGE).

A ferrovia do planalto (1817), e posteriormente a abolição da escravatura (1889) reduziram drasticamente a produção e o comércio local, fazendo com que a cidade permacesse estagnada. Somente em 1932, com o estabelecimento da ligação viária de São Sebastião com o Vale do Paraíba, o porto foi reativado para escoar os produtos provenientes do Vale (IBGE).

A instalação do terminal marítimo da Petrobrás (TEBAR), onde atualmente passam $60 \%$ do petróleo destinado às refinarias do planalto também foi relevante para a economia 
local. No fim da década de 70, com a construção da rodovia Rio-Santos, o município acabou tornando-se importante estância turística do estado (IBGE).

\subsubsection{Características ambientais, sócio-econômicas e sanitárias}

O município de São Sebastião dista $199 \mathrm{Km}$ da capital e situa-se no litoral nordeste do estado de São Paulo. São Sebastião faz divisa com Caraguatatuba ao norte, com Bertioga ao sul e com a Ilhabela através do Canal de São Sebastião. Sua área de 403,34 $\mathrm{Km}^{2}$ é constituída majoritariamente pelo bioma da Mata Atlântica. A região é caracterizada por estreita planície costeira e litoral bastante recortado, sendo constituído por 42 praias (CETESB, 2004).

A concentração urbana do município ocorre na face voltada para o canal de São Sebastião, onde está localizada a sede do município e o terminal Petrolífero da Petrobrás (CETESB, 2004).

De acordo com o censo realizado em 2009, estima-se que o município possua 73.631 habitantes (IBGE, 2010). No entanto, em épocas de temporada (verão e finais de semana prolongados), a população aumenta consideravelmente, podendo até mesmo dobrar, alterando a rotina local e a demanda por água, coleta de esgoto e lixo (CETESB, 2004).

Segundo dados da Fundação Seade (2000 apud CETESB, 2004) o índice de atendimento de esgoto no município gira em torno de 36,5\%, insuficiente para atender tanto a população local quanto a população flutuante dos meses de verão. $\mathrm{O}$ município possui dois emissários submarinos de esgoto doméstico localizados no Canal que são mantidos pela Sabesp. O emissário do Araçá atende a uma população máxima de 21.396 pessoas, enquanto que o das Cigarras tem capacidade para atender a uma população de 1.600 pessoas. O município de Ilha Bela também possui um emissário de esgoto doméstico, localizado no Canal de São Sebastião. Esse emissário é nomeado como Saco da Capela, sendo destinado ao atendimento de 4.848 pessoas, (CETESB, 2004).

Também há um emissário submarino operado pela Petrobrás para o despejo de efluentes dos tanques separadores de água e óleo bem como de águas pluviais que, de certa forma, limpam as instalações carreando os materiais ali presentes (CETESB, 2004). 
O turismo é uma importante atividade para a economia local, além de serviços relacionados ao Terminal Marítimo Almirante Barroso, com atividades petrolíferas e de carga, além do comércio diversificado gerado por essa atividade (CETESB, 2004).

\subsection{Contexto geológico e caracterização oceanográfica do Canal de São Sebastião}

O Canal de São Sebastião (CSS) $\left(23^{\circ} 40^{\prime} \mathrm{S}\right.$ e $23^{\circ} 53.5^{\prime} \mathrm{S}$ e $45^{\circ} 19^{\prime}$ e $\left.45^{\circ} 30^{\prime} \mathrm{W}\right)$ é uma feição de $25 \mathrm{~km}$ de comprimento, que separa o continente da Ilha de São Sebastião (Ilha Bela) (Fig. 02). Apresenta larguras variáveis de 2 km, em sua porção central, e 7 km, em suas entradas sul e norte. Seu eixo, onde estão as maiores profundidades (30 a 50 m), está deslocado para o lado insular, devido à erosão e/ou condicionamento estrutural das rochas. As menores profundidades $(6 \mathrm{~m})$ são encontradas no lado continental do canal. As entradas sul e norte apresentam profundidades, de 25 e $20 \mathrm{~m}$, respectivamente.

A Ilha de São Sebastião tem sua gênese ligada à atividade vulcânica alcalina, e à reativação de falhas pré-existentes, ocorridas no sudeste brasileiro no final do período Cretáceo, representadas pelo soerguimento da Serra do Mar e pela subsidência da Bacia de Santos. A Ilha de São Sebastião, oriunda desses eventos magmáticos, seria remanescente do retrocesso erosivo sofrido pela Serra do Mar (Almeida, 1976).

A fonte de sedimentos para o canal é proveniente do retrabalhamento de depósitos preexistentes, de contribuição costeira adjacente e de material em suspensão de áreas externas ao canal (Furtado, 1995). A distribuição de sedimentos ao longo do canal está relacionada à sua geometria, topografia de fundo e circulação local. A geometria do canal, mais especificamente sua curvatura, assemelha-se a de um canal fluvial, apresentando margens deposicional (lado continental) e erosiva (lado insular). A topografia do CSS é extremamente irregular, com grandes variações em pequeno espaço, produzindo distribuição dos sedimentos em manchas, com tamanhos variados (Furtado, 1995; Barcellos \& Furtado, 1999, 2001).

A circulação do canal caracteriza-se por movimentos norte e sul, com periodicidade de dias, pouco influenciados pelas correntes de maré (Castro-Filho, 1990; Fontes, 1995; Miranda \& Castro-Alves, 1995). A geometria e a topografia do fundo do canal condicionam correntes mais intensas no sentido longitudinal do lado insular, com 
velocidades de até $1,0 \mathrm{~m} \cdot \mathrm{s}^{-1}$ para o norte e $0,7 \mathrm{~m} \cdot \mathrm{s}^{-1}$ para sul (FUNDESPA, 1999). As características termohalinas do canal são determinadas pelo transporte de massas d'água da plataforma continental, cujos movimentos são predominantemente gerados pelo vento e por forças de gradiente de pressão.

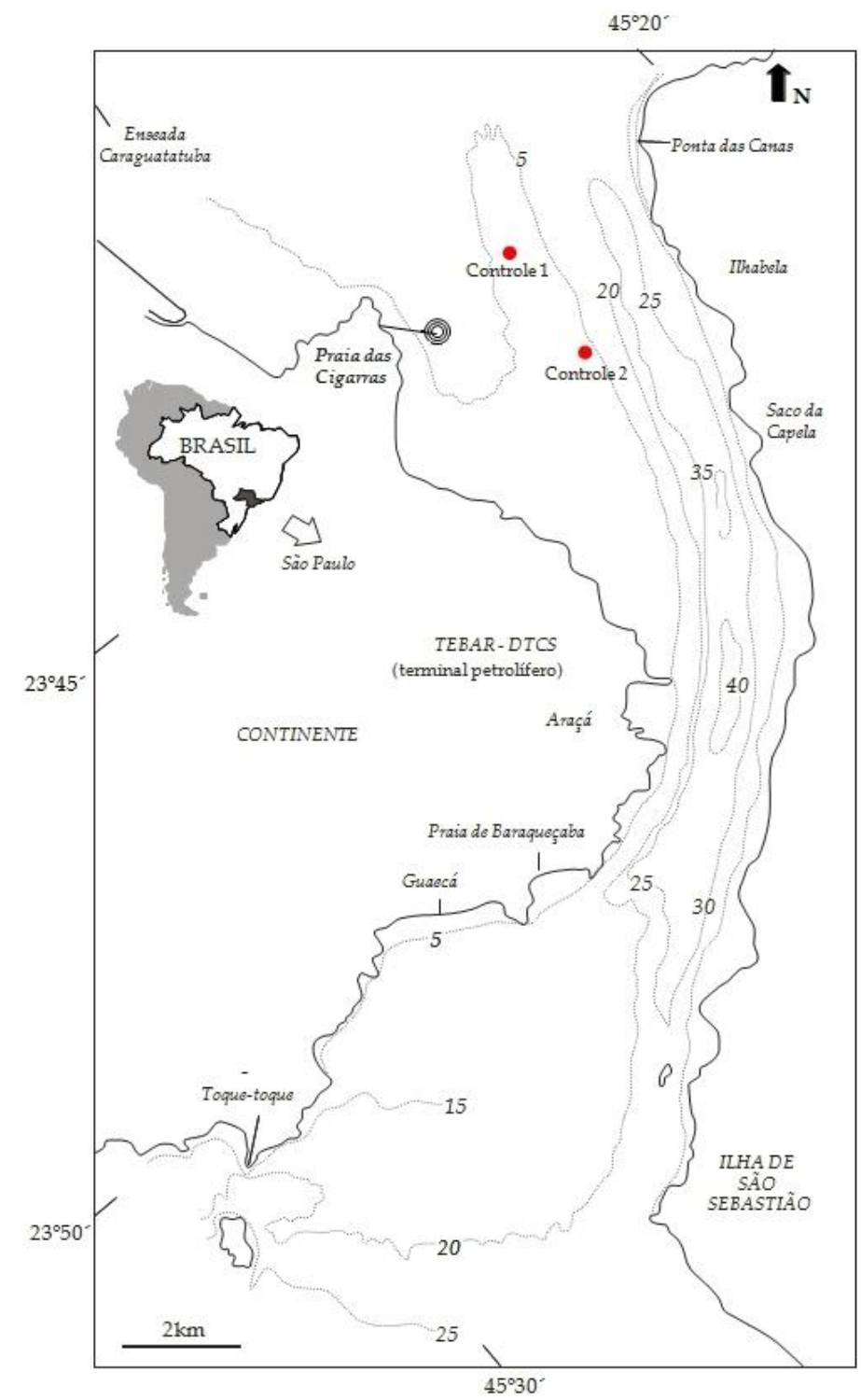

Fig. 02: Localização da área de estudo (modificado de Gubitoso, 2010).

\subsection{Praia das Cigarras e descrição do emissário submarino de esgoto}

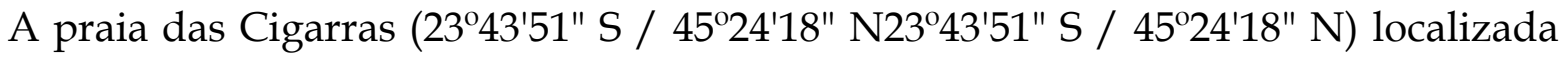
no município de São Sebastião, bairro do Barro, está situada na extremidade da entrada 
norte do CSS (Fig. 03). Por encontrar-se no lado deposicional do CSS, essa praia tende a apresentar grande concentração de sedimentos pelíticos (Furtado, 1998). Trata-se de um ambiente raso, com profundidades inferiores a 10 metros. As marés oscilam entre -0,848 e $+2,232 \mathrm{~m}$. As corrente se movimentam em direção a nordeste, com velocidade de $0,2 \mathrm{~m} \cdot \mathrm{s}^{-1}$ (Marcellino, 2000).

Vistorias realizadas em 1985 no emissário submarino de esgoto das Cigarras constataram problemas em seu funcionamento (Fig. 04 A). Após análises, decidiu-se que a implantação de um novo emissário era mais viável economicamente do que restaurar o existente. Dessa maneira, em 1994 um novo emissário submarino foi instalado no local, nas coordenadas $45^{\circ} 23^{\prime} 419^{\prime \prime}$ S e $23^{\circ} 43^{\prime} 961^{\prime \prime} \mathrm{W}$ (Sabesp, 2006).

O novo emissário foi projetado para atender a uma população máxima de 1600 pessoas. Seu comprimento total é de $1068 \mathrm{~m}$, apresentando um trecho terrestre que percorre $45 \mathrm{~m}$ paralelamente à praia antes de entrar no mar (CETESB, 2007). Localiza-se junto ao assoalho marinho a uma profundidade média de $8,5 \mathrm{~m}$. Seu diâmetro interno é de $16 \mathrm{~cm}$. O tubo difusor possui um comprimento total de $6,0 \mathrm{~m}$, tendo 22 orifícios difusores com $5 \mathrm{~cm}$ de diâmetro. Entre os furos difusores há um espaçamento de $25 \mathrm{~cm}$. No período de baixa temporada, sua vazão é de 1,5 L/s, já em alta temporada, esse valor chega a 7,6 L/s, com uma vazão máxima de 11,6 L/s (Sabesp, 2006).

A estação elevatória é feita de concreto com diâmetro do poço de 1,90 m e 4,68 m de profundidade, sendo acionada por dois conjuntos de bombas que trabalham alternadamente. Para remoção de sólidos grossos e areia utiliza-se sistema de gradeamento médio. Os resíduos sólidos retidos são levados semanalmente para o aterro da prefeitura, enquanto que as areias acumuladas são retiradas trimestralmente. Visando uma operação adequada no bombeamento do esgoto, implantou-se uma chaminé de equilíbrio junto à estação elevatória. A chaminé apresenta 8,0 m de altura e 1,2 $\mathrm{m}$ de diâmetro e evita a queda repentina de carga de esgoto com a parada do bombeamento em situações transitórias. Antes da disposição oceânica, o efluente é submetido à cloração (Fig. 04 B) (Sabesp, 2006). 


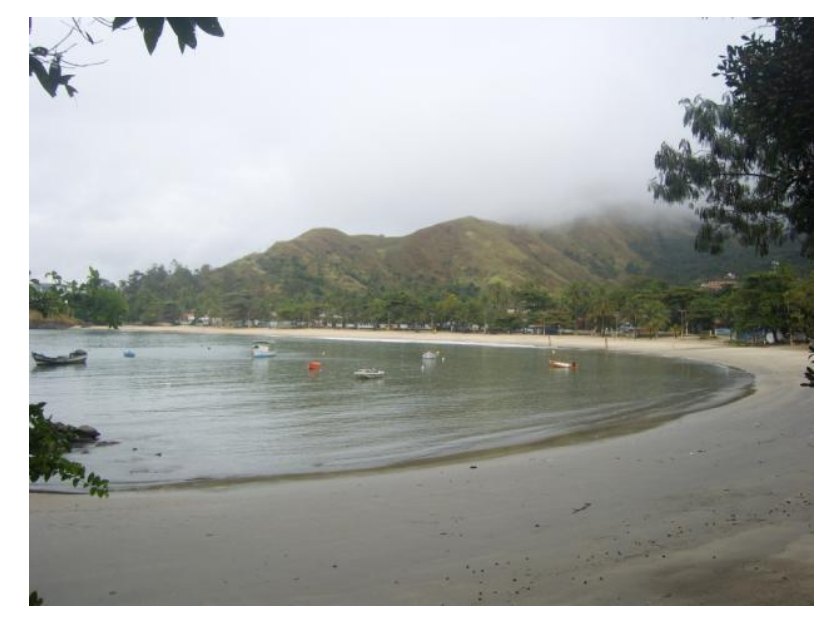

Figura 03: Praia das Cigarras. (Foto Luciana S. Filippos).
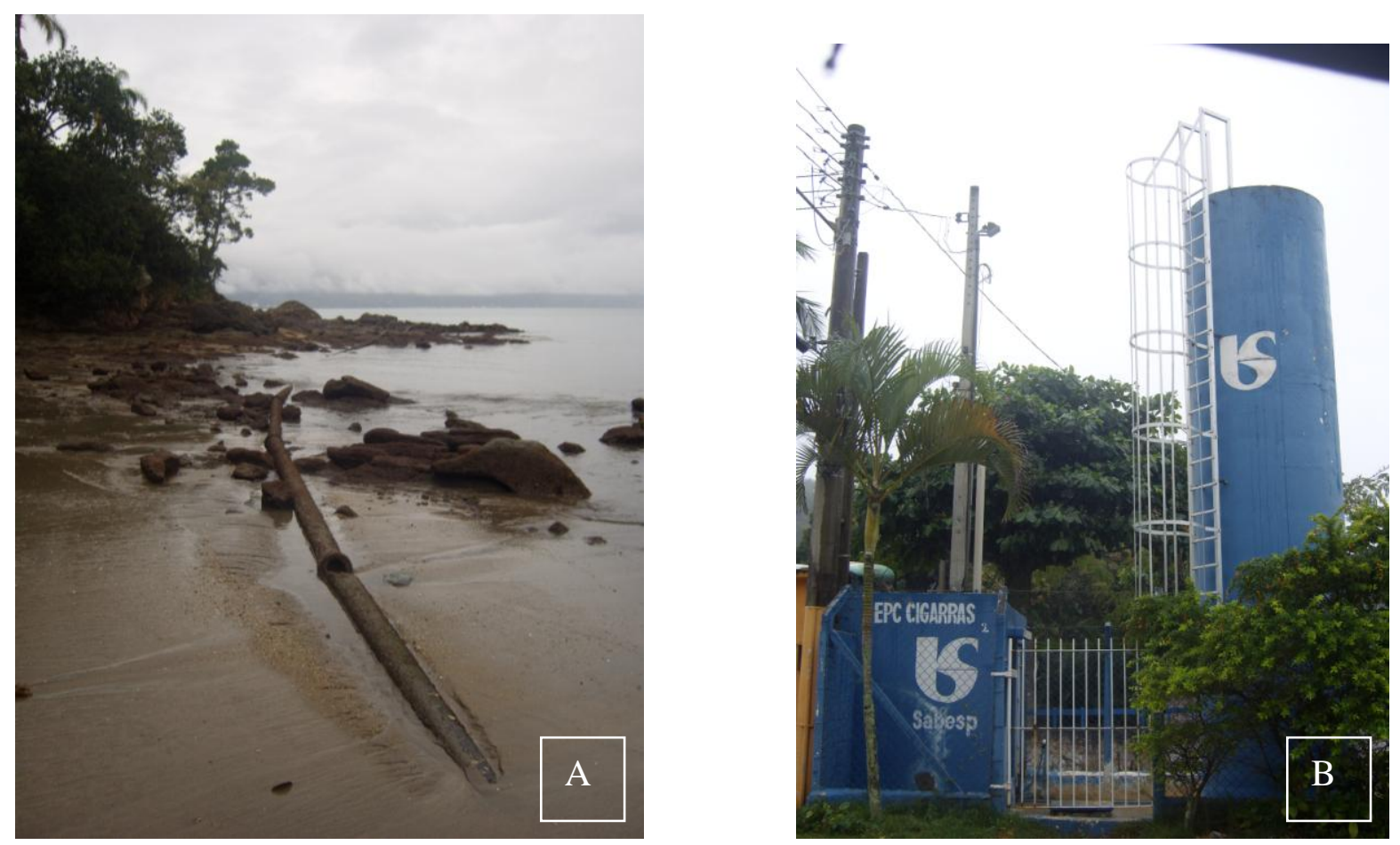

Figura 04: A: Antigo emissário de esgoto abandonado próximo ao costão da ponta esquerda da praia. B: Estação de pré-condicionamento das Cigarras (Fotos Luciana S. Filippos). 


\section{MATERIAIS E MÉTODOS}

\subsection{Procedência das amostras:}

Foram analisadas 20 amostras de sedimentos, coletadas na área circunjacente ao emissário submarino de esgoto das Cigarras, em 2006 (27/28 de setembro) e em 2007 (4 de setembro). As coletas foram realizadas em 10 pontos pré-determinados aleatoriamente de uma rede amostral do tipo círculo crescente, situada ao redor das saídas dos difusores, na área de influência da disposição de esgoto pelo emissário (CETESB, 2008) (Fig. 05). Esse tipo de malha amostral é comumente utilizado em áreas de poluição pontual, como emissários submarinos de esgoto, para avaliar a contaminação dos sedimentos. O padrão de amostragem baseia-se no fato de que quanto mais se afasta da fonte de contaminação, menor será o impacto causado. Assim, como nos sistemas naturais a distribuição dos contaminantes está susceptível a correntes e outros fatores físicos que afetam a sua dispersão, a malha amostral inicia-se com uma distância " $x$ " da fonte e as demais amostras são coletadas a distâncias cada vez maiores -“2x”, “4x”, etc (Macknight, 1994).
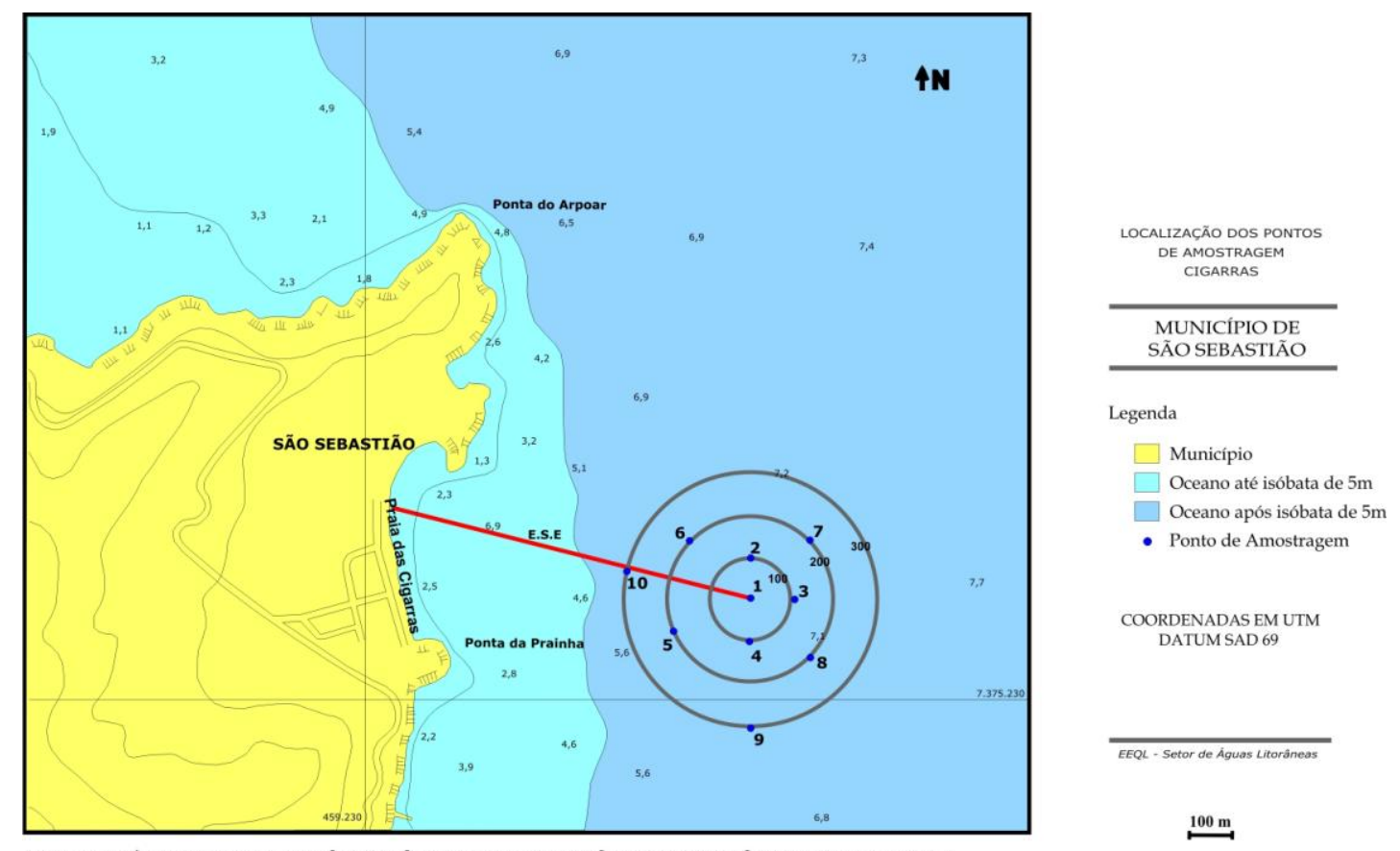

Figura 05: Malha amostral da Praia das Cigarras (modificada de CETESB, 2008). 
Duas outras amostras de sedimento foram coletadas, fora da malha amostral círculo crescente (Fig. 05), em uma área do CSS com pouca influência antrópica, visando servir como pontos controles, em março (Fig. 06).

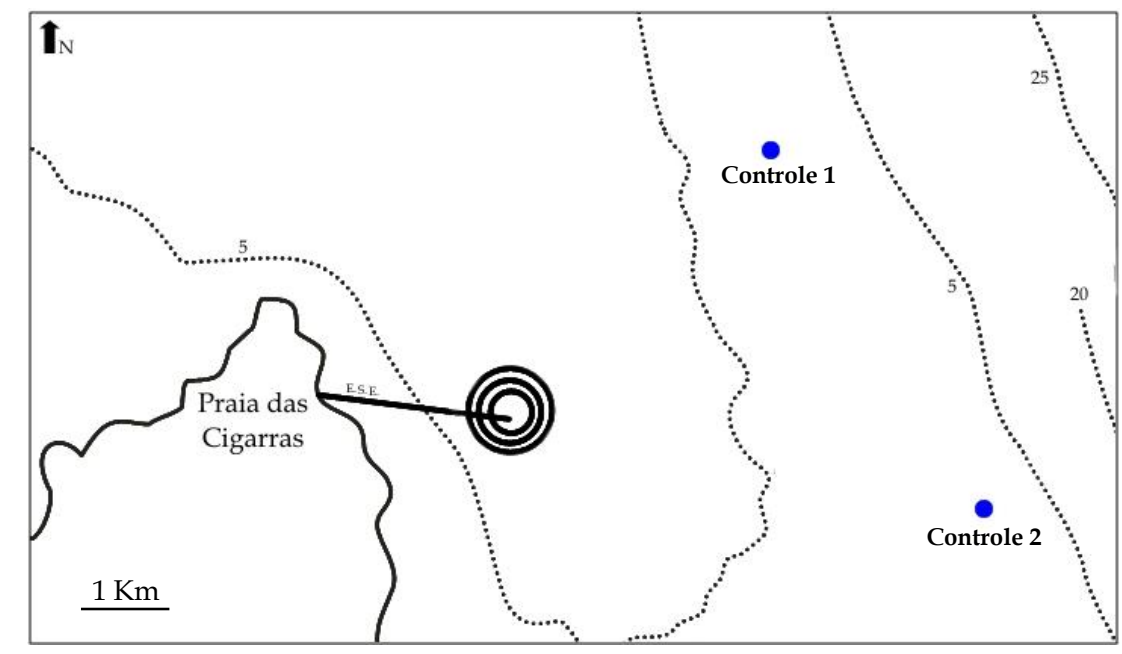

Figura 06: Localização dos pontos controles. A malha círculo crescente está representada pelos círculos pretos. E.S.E.= emissário submarino de esgoto das Cigarras.

Os pontos são georreferenciados e as coletas foram realizadas sempre no mesmo local com o auxílio de GPS (sistema de posicionamento global). O perfil da coluna d'água foi analisado, em cada ponto amostral, através do uso de sonda multiparâmetros em três diferentes profundidades: superfície, meio e fundo. Essa sonda possibilita a análise de parâmetros como: profundidade, temperatura da água, turbidez, salinidade, $\mathrm{pH}$ e oxigênio dissolvido (CETESB, 2008). Nesses pontos também foram coletados sedimentos para o estudo granulométrico, geoquímico e do conteúdo de foraminíferos.

As amostras de sedimento foram coletadas com um pegador tipo Petersen, e subdivididas em três frações. A primeira fração, para análise de foraminíferos, foi corada com Rosa de Bengala e preservada em álcool $70{ }^{\circ} \mathrm{GL}$ (Walton, 1952). A segunda visou análises geoquímicas de C, N e S. Já a terceira, destinada ao estudo dos HPAs, foi armazenada em frasco de vidro âmbar com tampa de teflon, no intuito de evitar contaminações. Todas as amostras foram estocadas sob refrigeração a $4{ }^{\circ} \mathrm{C}$ (Mudroch \& Macknight, 1994) e transportadas até o laboratório para secagem. 


\subsection{Laboratório de Sedimentologia - IGcUSP}

Amostras de sedimento, previamente secas em estufa a $60{ }^{\circ} \mathrm{C}$, foram submetidas a análise granulométrica de acordo com as técnicas de pipetagem e peneiramento descritas em Suguio (1973) (Fig. 07).

A fração inferior a 0,063 mm (silte e argila) foi analisada através da pipetagem. Essa técnica baseia-se na Lei de Stockes, que considera que as partículas pequenas decantam com velocidade constante em água. Assim, ao coletarem-se amostras consecutivas em uma mesma profundidade, serão obtidos progressivamente sedimentos mais finos (McManus, 1988). Visando realizar uma análise correta, durante o preparo da amostra acrescenta-se um agente dispersante (pirofosfato de sódio- $\mathrm{Na}_{4} \mathrm{P}_{2} \mathrm{O}_{7}$ ) para evitar a floculação das partículas finas, ou seja, para impossibilitar a atração entre elas com a conseqüente formação de agregados (Suguio, 1973).

A análise por peneiramento é realizada para as partículas de sedimento compreendidas entre $0,063 \mathrm{~mm}$ a 2,00 $\mathrm{mm}$. Ela é constituída por uma fase preliminar denominada elutriação ou deslamagem, que consiste na lavagem da amostra, visando à eliminação dos sedimentos finos (silte e argila). Após essa etapa, a amostra é filtrada a vácuo e mantida em estufa a 50C por cerca de 12-24 horas (Suguio, 1973).

O peneiramento propriamente dito é realizado através de um conjunto de peneiras empilhadas com malha decrescente do topo para a base. A amostra é despejada na peneira superior e o conjunto é submetido à peneiramento mecânico através de vibrador acoplado em caixa para amortecer o ruído e a vibração por cerca de 20 minutos. Posteriormente, o material retido em cada peneira é pesado e então calculam-se as porcentagens de cada fração granulométrica (Suguio, 1973). 


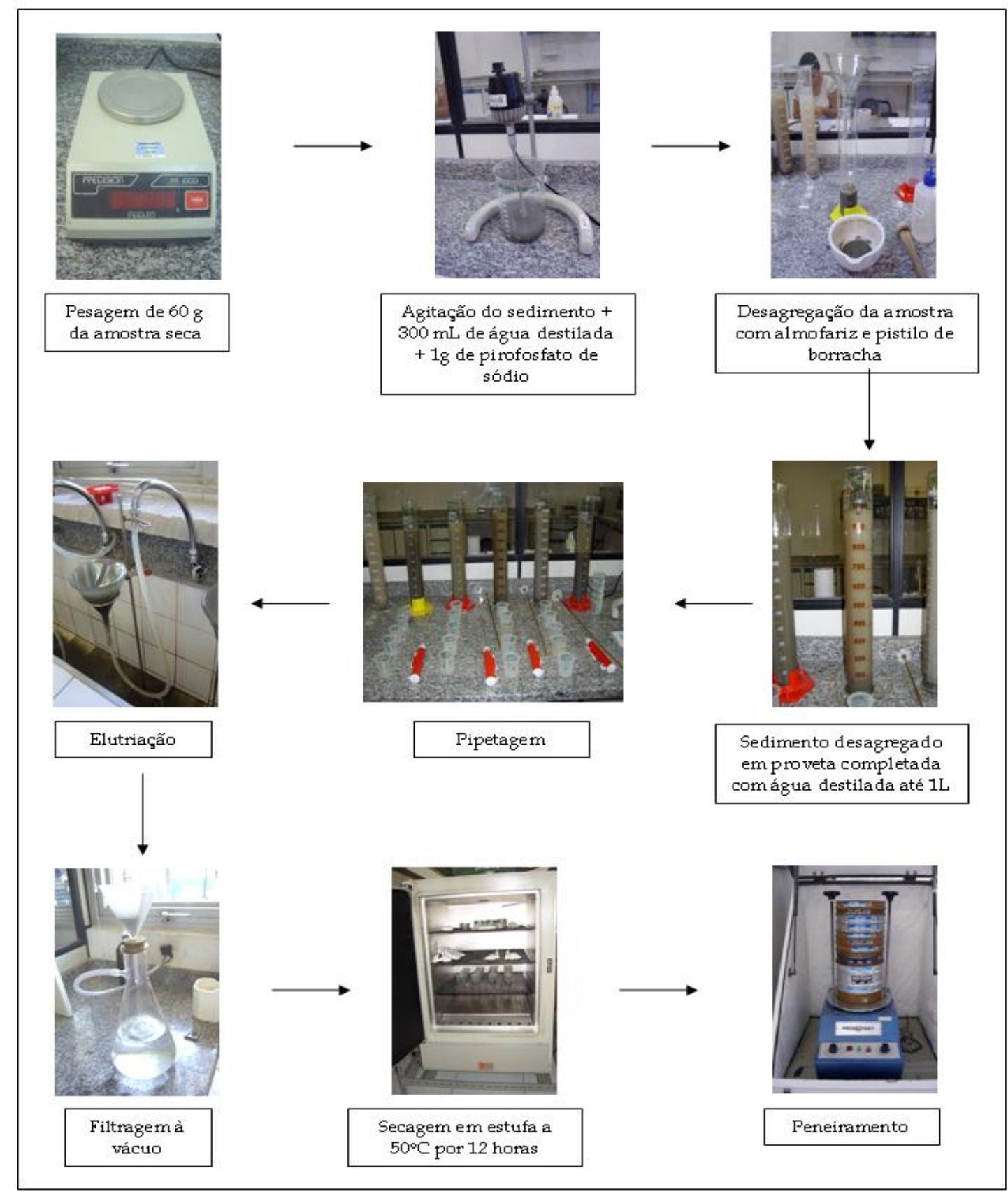

Figura 07: Fluxograma das etapas da análise de granulometria por pipetagem e peneiramento (modificado de Mello et al., 2004) (Fotos Luciana S. Filippos).

A partir dos resultados obtidos, os sedimentos foram classificados segundo Shepard (1954) e foram calculados os parâmetros estatísticos de Folk e Ward (1957). 


\subsection{Laboratório de preparação de amostras - IGcUSP}

Os sedimentos coletados, previamente secos em estufa a $60{ }^{\circ} \mathrm{C}$, foram peneirados em malha de aço inoxidável de $1 \mathrm{~mm}$, visando remover material mais grosso, como fragmentos de conchas. Posteriormente, os mesmos foram pulverizados em moinho de ágata e subamostrados para as análises de C, N e S (Fig. 08).

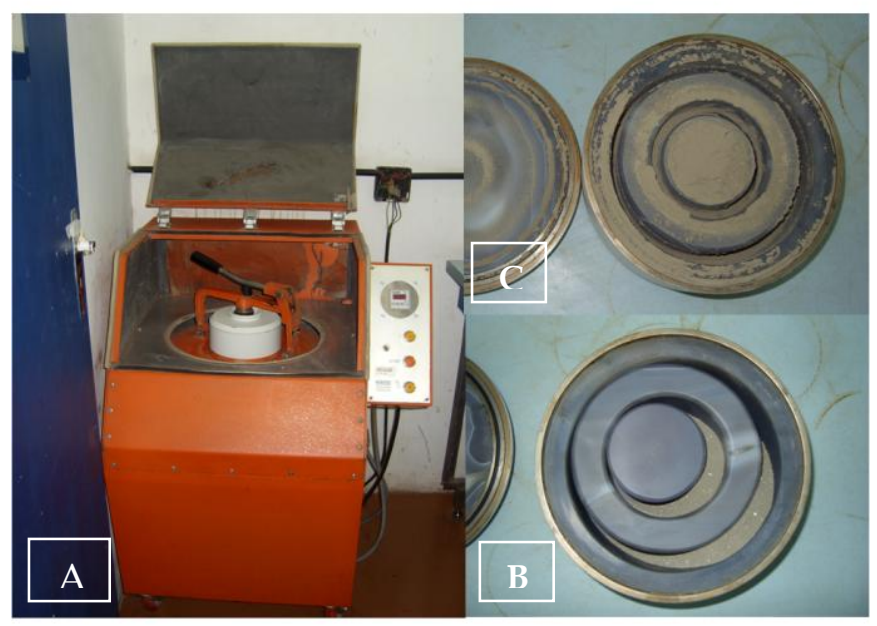

Figura 08: A: Moinho de ágata. B: panela de ágata com sedimento. C: panela de ágata com sedimento (Fotos Luciana S. Filippos).

\subsection{Laboratório Química - IGcUSP}

Os sedimentos secos e pulverizados foram subdivididos em duas partes: a primeira para a análise de carbono orgânico e a segunda para a análise de carbono, nitrogênio e enxofre totais.

Para a determinação dos teores de carbonato de cálcio (carbono inorgânico) do sedimento, utilizou-se a dissolução ácida com posterior diferença de peso (Gross, 1971).

Uma quantia de $10 \mathrm{~g}$ de sedimento proveniente da primeira fração foi tratada com $100 \mathrm{~mL}$ de com ácido clorídrico ( $\mathrm{HCl} \mathrm{10 \% ),} \mathrm{durante} 24$ horas em capela. Posteriormente, a amostra foi lavada com água destilada, utilizando-se Kitasato conectado a tubulação de vácuo, para eliminar o ácido presente. $\mathrm{O}$ material retido no papel filtro foi submetido à 
secagem em estufa a $50{ }^{\circ} \mathrm{C}$ por 12 horas. Para calcular o teor de carbonato, a amostra seca foi pesada e subtraída da massa inicial de sedimento através da equação abaixo (eq. 1):

$$
\mathrm{T}_{\mathrm{CaCO} 3}=\left[\left(\mathrm{P}_{1}-\mathrm{P}_{2}\right) / \mathrm{P}_{1}\right] \times 100
$$

Em seguida, os sedimentos foram classificados de acordo com o teor de carbonato de cálcio presente nas amostras em: litoclásticos, valores inferiores a 30\%; litobioclásticos, entre 30 e 50\%; biolitoclásticos, entre 50 e 70\%; e bioclásticos, superiores a 70\% (Larssoneur, 1977).

As análises de carbono orgânico, carbono e nitrogênio totais foram realizadas no equipamento $\mathrm{CHN}-1000$ da $\mathrm{LECO}^{\circledR}$, do Instituto de Química (IQ-USP). Já o enxofre total dos sedimentos foi calculado através do equipamento SC-432 da $\mathrm{LECO}^{\circledR}$, pertencentes ao Laboratório de Química do Instituto de Geociências (GMG-IGcUSP) (Fig. 09).

Os equipamentos da $\mathrm{LECO}^{\circledR}$ utilizam-se do método de perda de ignição (loss of ignition-LOI) em forno com temperatura em cerca de 1000 `C. Essa técnica consiste no superaquecimento da amostra para que as substâncias voláteis escapem e possam ser identificadas e quantificadas (Andrade et al., 2009).

Para as análises de carbono e nitrogênio, uma pequena amostra de sedimento pulverizado (> $400 \mathrm{mg}$ ) é submetido a ignição em forno com corrente de oxigênio a temperaturas superiores a $1100{ }^{\circ} \mathrm{C}$, sem a adição de catalisadores. Esse processo faz com que os compostos voláteis sejam liberados da amostra, permitindo sua posterior identificação e quantificação. O carbono é determinado por células infravermelhas, enquanto que o nitrogênio por células de condutividade termal (Andrade et al., 2009).

Para a análise de enxofre, uma pequena amostra de sedimento pulverizado (cerca de $350 \mathrm{~g}$ ) acrescida do catalisador COMCAT $^{\circledR}$ (agente oxidante) é submetida à ignição em forno a 1350 'C com fluxo de oxigênio puro. O catalisador permite a ocorrência da decomposição oxidativa, fazendo com que o enxofre presente na amostra seja liberado, sendo posteriormente quantificado através de células de detecção infravermelhas (Andrade et al., 2009). 


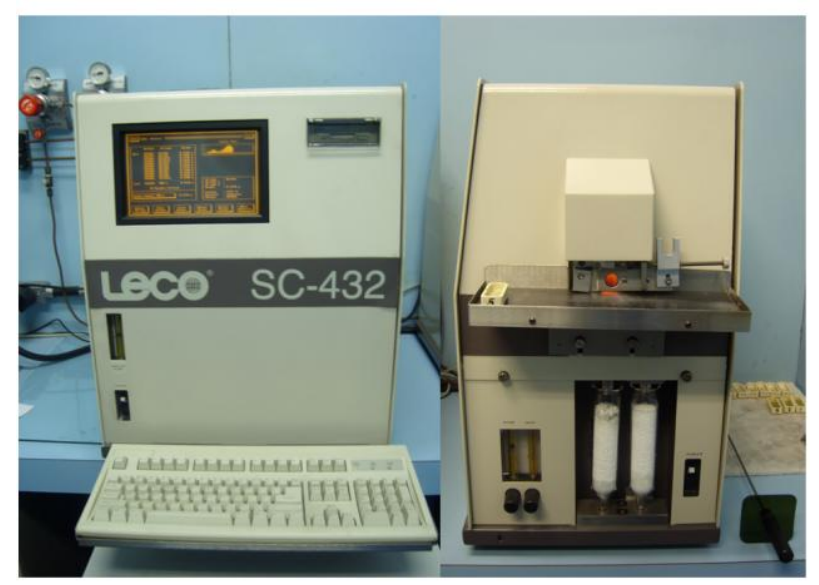

Figura 09: Equipamento LECO $®$ SC-432 (Foto Luciana S. Filippos).

A partir dos resultados desses elementos, foram calculadas as razões $\mathrm{C} / \mathrm{N}$ e $\mathrm{C} / \mathrm{S}$, visando inferir a origem da matéria orgânica e o potencial redox do ambiente de estudo.

As razões de $\mathrm{C} / \mathrm{N}$ inferiores a 6 indicam matéria orgânica de origem marinha, enquanto que valores superiores a 12 indicam origem continental. Já valores intermediários correspondem a mistura dessas duas fontes de contribuição (Stein, 1991).

As razões de C/S inferiores a 1,5 são características de ambiente com coluna d'água e sedimentos anóxicos (Berner, 1983; Hedge \& Keil, 1995), enquanto que valores superiores a 5 indicam que tanto a coluna d'água como os sedimentos apresentam características óxicas (Cetecioğlu et al., 2009). Já valores intermediários inferem ambiente com sedimento anaeróbio e coluna d'água oxigenada (Hedge \& Keil, 1995).

\subsection{Laboratório LabCorp (Análise dos HPAs)}

A secagem das amostras destinadas às análises dos HPAs foi realizada de acordo com a metodologia descrita em Almeida e Jardim (2006). Desta maneira, os sedimentos foram espalhados em placas de Petri e cobertos por papel alumínio com furos, visando evitar contaminações por material particulado. A seguir, as placas contendo as amostras de sedimento foram colocadas em capela de fluxo de ar por 8 dias.

Após o término da secagem, as amostras foram embrulhadas em papel alumínio e armazenadas em armário sem ter contato com luz por cerca de 6 meses. Posteriormente, 
cada amostra foi pulverizada manualmente em almofariz de ágata, visando evitar possíveis contaminações, e armazenadas em frascos de vidro âmbar (Schott).

As amostras foram encaminhadas ao laboratório LabCorp para serem realizadas as análises das concentrações dos 16 congêneres no sedimento estabelecidos pela EPA. Para a extração dos compostos, utilizou-se a metodologia USEPA 3550c (extração por ultrasom) e posteriormente a USEPA 8270d (cromatografia a gás/espectômetro de massa - GC/MS). O limite de detecção utilizado foi de 5,0 $\mu \mathrm{g} / \mathrm{Kg}$. Os "surrogates" acrescentados ao sedimento antes da extração, para verificar a porcentagem de recuperação, foram o 2Fluorobifenil e Terfenil-d14.

A cada 20 amostras analisadas, foi feito o branco do método e LCS (laboratory control samples). O branco do método consiste em uma amostra sem contaminações que é submetida às mesmas etapas analíticas que os sedimentos analisados. Ele é fundamental para monitorar possíveis interferências analíticas causadas por contaminações proveniente do laboratório, como reagentes utilizados, vidraria e equipamento. O LCS é um branco fortificado com uma quantidade conhecida de analitos-alvo. Essa amostra é analisada da mesma forma que o branco do método e visa avaliar a exatidão da técnica utilizada.

Como ainda não existe legislação brasileira para os sedimentos, os dados de HPAs foram comparados com os critérios de qualidade estabelecidos pelo Canadá (CCMECanadian Council of ministers of the Environment).

\subsection{Laboratório de Micropaleontologia - IGcUSP}

O estudo abrangeu tanto a análise da tanatocenose (foraminíferos mortos) quanto da biocenose (indivíduos vivos), já que o padrão de distribuição dos mortos corresponde a uma mistura de espécimes que sofreram transporte, retrabalhamento e redeposição, enquanto que dos vivos representa o ambiente in situ (Bandy et al., 1964).

Segundo Zalesny (1959), após muitos experimentos, verificou-se que a contagem de 300 carapaças de indivíduos é suficiente para descrever a tanatocenose da área de estudo, já que as frequências relativas variam muito pouco quando comparadas com a análise de milhares de espécimes. Assim, para a determinação dos foraminíferos mortos, utilizou-se uma alíquota de $10 \mathrm{~cm}^{3}$ de sedimento de cada ponto amostral, sendo triadas 
aproximadamente 300 carapaças. Na maioria das vezes, devido ao alto número de indivíduos, as amostras foram subdivididas. Já para o estudo dos vivos foram utilizadas alíquotas de $10 \mathrm{~cm}^{3}$ até obter-se 100 testas (Murray, 1991).

A distinção entre a tanatocenose e a biocenose foi realizada através do uso do corante Rosa de Bengala (Fig. 10). A sua utilização faz com que indivíduos que se encontram vivos no momento da coleta tornem-se rosados, devido ao tingimento de seu citoplasma com o corante. Já os representantes mortos não se coram.

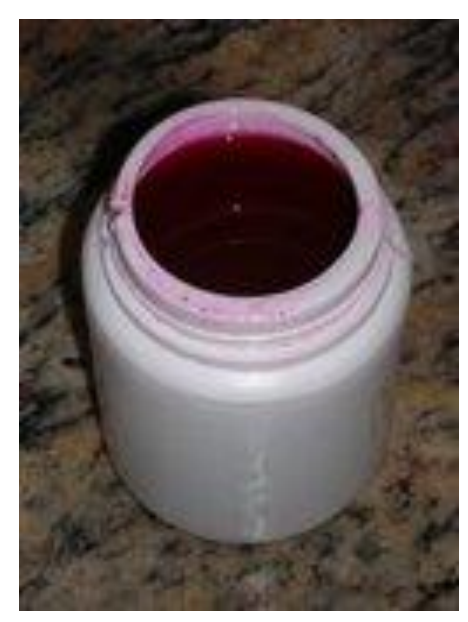

Figura 10: Amostra de sedimento corada com Rosa de Bengala (Foto Luciana S. Filippos).

O material foi então peneirado a úmido em malhas de 0,500 e 0,062 mm (Schröder et al., 1987) (Fig. 11 A). As frações retidas nas peneiras foram secas e submetidas à análise densimétrica por flutuação-afundamento em tricloroetileno, visando separar os foraminíferos do sedimento (Scott et al., 2001) (Fig. 11 B). 


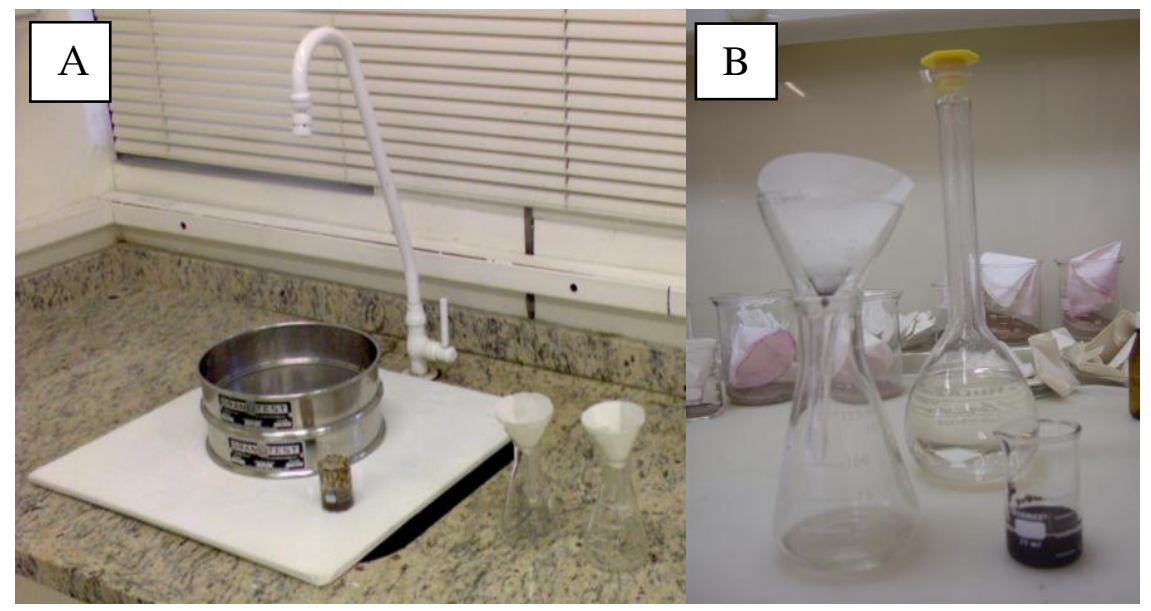

Figura 11: A: Lavagem a úmido do sedimento em peneiras de malha de 0,500 e 0,062 mm. B: Separação densimétrica dos foraminíferos. (Fotos Luciana S. Filippos).

A seguir, as carapaças foram triadas, fixadas (com goma adragante) em portaforaminíferos, identificadas e contadas com o auxílio de lupa binocular (ZEISS - Stemi SV6) (Fig. 12). Foram realizadas microfotografias de vários exemplares utilizando-se microscopia eletrônica de varredura $(\mathrm{MEV})$ do Instituto de Geociências da USP, para confirmação taxonômica e tafonômica.

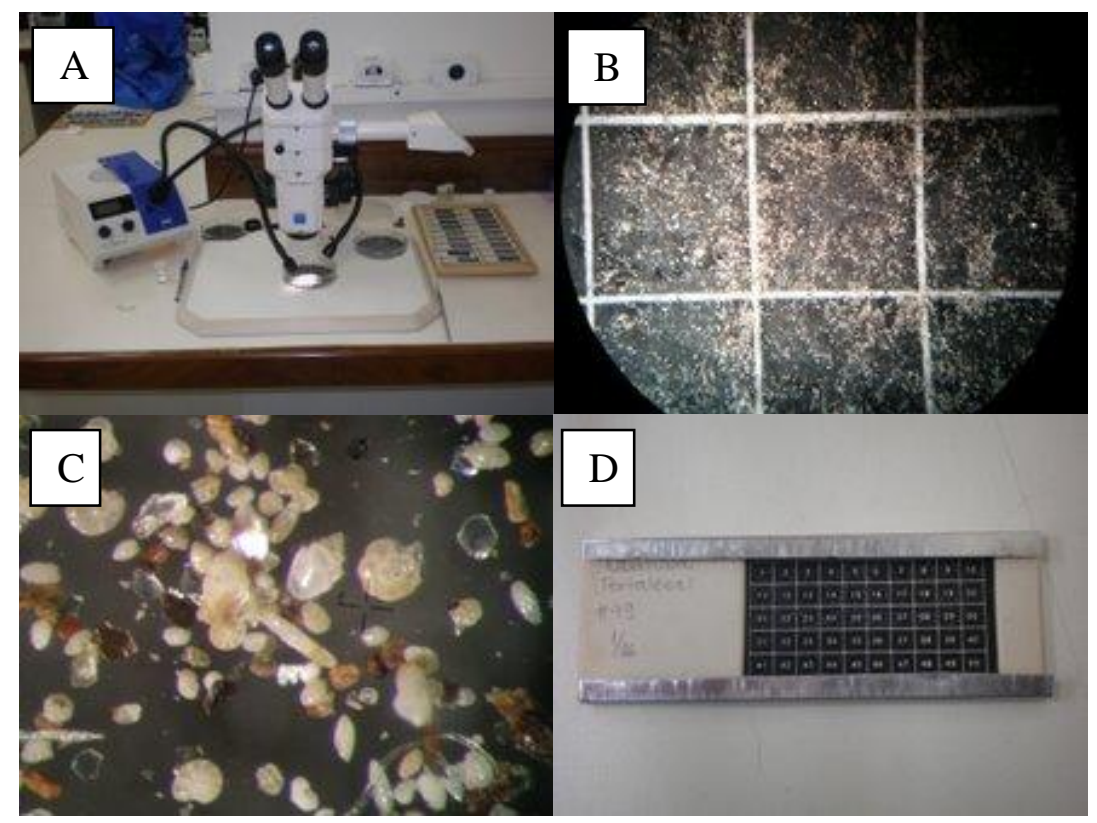

Figura 12: A: Lupa binocular. B: Grãos de sedimento e foraminíferos, x10. C: Grãos de sedimento e foraminíferos, x 60. D: Porta-foraminíferos (Fotos Luciana S. Filippos). 
A classificação genérica dos foraminíferos baseou-se em Loeblich \& Tappan (1964, 1988), e as espécies em monografias e no atlas de foraminíferos do Atlântico norte e sul (Cushman, 1923, 1929, 1930 e 1931; Boltovskoy et al., 1980). Também foram consultados trabalhos taxonômicos específicos de determinados gêneros e espécies, como Elphidium excavatum s.l. (Miller et al., 1982), bem como a coleção micropaleontológica do IGcUSP.

Após a identificação taxonômica, foram elaborados mapas de densidade (indivíduos $/ \mathrm{cm}^{3}$ ), riqueza (número de espécies por amostra) e frequências das subordens, sendo classificados como: raro (<1\%), escasso (1 a 5,9\%), disperso (6 a 11,9\%), pouco freqüente (12 a 23,9\%), freqüente (24 a 35,9\%), muito freqüente (36 a 49,9\%) e predominante $(>50 \%)$ (Tinoco, 1989).

As carapaças triadas foram submetidas a análises morfométricas, através do analisador de imagens Analysis do Laboratório de Micropaleontologia do IGc-USP, sendo então classificadas em pequenas $(<125 \mu \mathrm{m})$, médias $(125$ - $250 \mu \mathrm{m})$, grandes $(250$ - $500 \mu \mathrm{m})$ e muito grandes (> $500 \mu \mathrm{m})$. O tamanho das carapaças baseia-se na escala granulométrica de Wentworth (1922) em fino, médio, grosso e muito grosso, respectivamente.

De acordo com as análises tafonômicas (para os mortos) e morfológicas (para os vivos), os indivíduos foram classificados como inteiros, parcialmente fragmentados e fragmentos.

As tecas das tanatocenoses foram classificadas segundo sua coloração em normais (sem coloração), limonitizadas (alaranjadas), preenchidas com monossulfeto de ferro (preenchimento preto) e piritizadas (preenchimento dourado).

Indicadores de ambiente rico em matéria orgânica e de oxigênio, presentes nas amostras, foram identificados e representados em figuras e tabelas. Também foram calculados os índices de diversidade de Shannon $\left(\mathrm{H}^{\prime}\right)$ (eq. 2) e a equitatividade de Shannon ou índice de Pielou ( $\left.\mathrm{E}_{\mathrm{H}}\right)$ (eq. 3), descritos em Magurran (1983). O pi presente nas fórmulas é a proporção da espécie em relação ao total de indivíduos e o S é a riqueza de cada amostra.

Os índices foram calculados a partir das fórmulas abaixo:

$$
\mathrm{H}^{\prime}=-\sum p i_{\mathrm{x}} \operatorname{Ln} p i
$$




$$
\mathrm{E}_{\mathrm{H}}=\mathrm{H}^{\prime} / \operatorname{LnS} \quad \text { (3) }
$$

Para a realização das análises de agrupamento, primeiramente os dados foram normalizados através da equação 4 , onde $x$ corresponde ao número absoluto de indivíduos de uma determinada espécie de uma amostra. A elaboração dos agrupamentos foi realizada pelo programa MINITAB, sendo utilizados somente os foraminíferos mais representativos das amostras ( $\mathrm{n}>40$ indivíduos).

$$
\operatorname{Ln} x+1 \quad(4)
$$

A análise de agrupamento possui várias abordagens, sendo a utilizada neste trabalho a hierárquica aglomerativa. Inicialmente, cada objeto de estudo encontra-se sozinho, sendo posteriormente agrupados de acordo com uma medida de similaridade, até que todos os objetos pertençam a um único agrupamento (Manly, 1994). Para isso, utiliza-se uma matriz de associação, visando determinar as distâncias entre os objetos e entre as bifurcações (nós) das árvores. Os membros do grupo podem ser definidos pelas distâncias ao centro do grupo, ao membro mais próximo, ao membro mais distante, entre outras (Magnusson \& Mourão, 2005).

A partir de uma matriz entre as espécies e os pontos amostrais, foram construídos dendogramas, utilizando a técnica Ward linkage, com nível de similaridade de 0,05. A análise de agrupamento $Q$ foi utilizada para verificar a similaridade ou dissimilaridade entre as estações em relação à sua composição faunística. Para isso utilizou-se a medida de distância euclidiana. Já a técnica $\mathrm{R}$ foi aplicada para avaliar a afinidade, ou seja, a semelhança entre as espécies presentes nas amostras. A medida de distância utilizada foi a de correlação.

No intuito de avaliar a semelhança ou não das tanatocenoses entre si, assim como das biocenoses entre si, utilizou-se o programa INSTAT, capaz de elaborar testes ANOVA não paramétrico de Kruskal-Wallis, seguido de comparação múltipla de Dunn.

Visando avaliar quais parâmetros ambientais influenciam as principais espécies presentes nas amostras, foram realizadas Análises Canônicas dos foraminíferos mortos e dos vivos através do Programa CANOCO versão 4.5. Somente as espécies mais 
representativas foram utilizadas. Para a análise da tanatocenose foram usadas espécies que somam mais de 40 indivíduos nos anos de 2006, de 2007 e pontos controles, enquanto que para a biocenose, a soma de ambos os anos junto com os pontos controles foi de pelo menos 19 indivíduos.

Antes da análise canônica propriamente dita, os dados foram normalizados por logaritimização. Foram utilizadas até 499 permutações entre os dados, através do uso da permutação de Monte Carlo.

\subsection{Laboratório de Microscopia Eletrônica de Varredura (LABMEV) - IGcUSP}

Na microscopia eletrônica de varredura, a área ou o microvolume a ser analisado é irradiado por um fino feixe de elétrons (Fig. 13 A). Esse feixe interage com a superfície da amostra, emitindo radiações que quando captadas fornecem informações sobre a amostra (topografia da superfície, composição, cristalografia, etc.) (Maliska, s/ ano).

Para a montagem dos stubs, podem ser usados vários tipos de adesivos como: colas condutoras de prata ou carbono coloidal, esmalte de unha em quantidade mínima e fitas adesivas (Fig, 13 B). Após a fixação do material a ser analisado, o stub é submetido ao processo de "sputtering" que deposita uma fina camada de ouro sobre toda a amostra. Isso é feito visando tornar os foraminíferos bons condutores térmicos e elétricos, já que tanto eles, quanto a fita adesiva ficam carregados negativamente durante a varredura do feixe eletrônico, podendo gerar brilhos excessivos em alguns pontos (Castro, 2002) (Fig. 13 C).

Cerca de 50 foraminíferos foram submetidos à análise, sendo que as fotomicrografias dos indivíduos mais representativos foram tratadas no programa de computador Adobe Photoshop CS3 versão 10.0 e dispostas em pranchas apresentadas em anexo. 


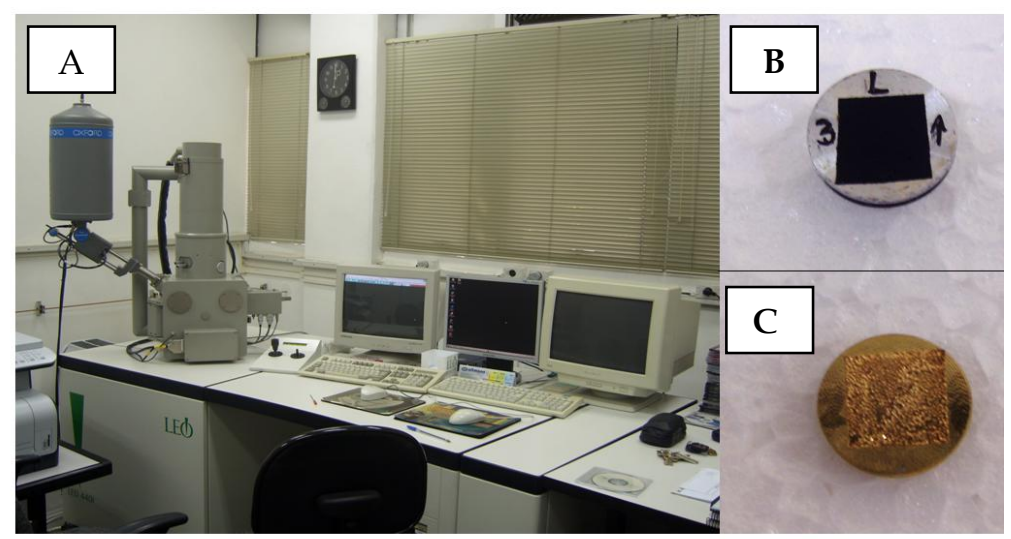

Figura 13: A: MEV. B: stub com fita adesiva de carbono. C: stub recoberto com ouro (Fotos Luciana S. Filippos). 


\section{RESULTADOS:}

\subsection{Setembro de 2006}

\subsubsection{Parâmetros hidrográficos e hidroquímicos}

Os padrões de qualidade utilizados neste trabalho referem-se às águas salinas classe 1, de acordo com o artigo $5^{\circ}$ da Resolução CONAMA 357/05. Os dados físico-químicos estão representados no Anexo 01.

A região é caracterizada como ambiente raso, apresentando profundidades que variam entre 5 e $6 \mathrm{~m}$. Os valores mínimos e máximos de salinidade, temperatura e $\mathrm{pH}$ oscilam entre 33,57 a 33,79, 21,95 a $22,51{ }^{\circ} \mathrm{C}$ e 8,11 a 8,18, respectivamente. Ao longo da coluna d'água não há ocorrência de estratificação vertical de salinidade, temperatura e pH. Todas as estações apresentam $\mathrm{pH}$ dentro das normas exigidas pelo CONAMA.

A coluna d'água apresenta altos valores de turbidez, sendo que os valores variam entre 16 a 37 unidades tefelométricas de turbidez (UNT) na superfície, de 13 a 36 UNT no meio, e 15 a 63 UNT no fundo. Os pontos amostrais 1, 2, 3, 8 e 9 apresentam maiores valores na superfície, enquanto que os demais possuem maior turbidez no fundo. Na maioria das estações há decréscimo de UNTs da superfície para o meio, com posterior acréscimo do meio para o fundo. Os valores obtidos pelo disco de Secchi corroboram com os dados de turbidez, já que a profundidade máxima onde foi possível enxergar o disco foi $0,6 \mathrm{~m}$.

A maioria das estações apresenta em todas as profundidades teores de oxigênio dissolvido inferiores ao estabelecido pela legislação (>6 mg. $\left.\mathrm{L}^{-1}\right)$. Os valores obtidos nesses pontos oscilam entre 4,92 mg.L-1 (\#4) e 5,83 mg.L-1 (\#3) (Anexo 01). As estações 5 e 9 são as únicas que apresentam valores dentro nas normas do CONAMA ao longo da coluna d'água. Com exceção da estação 4, as demais apresentam decréscimo dos valores de OD da superfície em direção ao fundo. 


\subsubsection{Parâmetros Granulométricos}

Os dados granulométricos da área de estudo estão representados na tabela 01.

Tabela 01. Dados granulométricos dos sedimentos de 2006. MPS= muito pobremente selecionado.

\begin{tabular}{|c|c|c|c|c|c|c|c|c|c|c|c|c|c|c|c|c|}
\hline \multirow{3}{*}{ Estação } & \multirow{3}{*}{$\begin{array}{l}\text { D. Médio } \\
\text { (Ф) }\end{array}$} & \multirow[b]{2}{*}{ Grau } & \multirow[b]{2}{*}{ Classificação } & \multirow[b]{2}{*}{ Classificação } & \multicolumn{12}{|c|}{ G R A N U L O ME T R I A (\%) } \\
\hline & & & & & \multicolumn{3}{|c|}{ Cascalho } & \multicolumn{6}{|c|}{ Areia } & \multicolumn{3}{|c|}{ Lama } \\
\hline & & de seleção o & o Folk \& Ward (1957) & Shepard (1954) & Seixos & Grânulos & Total & $\begin{array}{l}\text { Muito } \\
\text { grossa }\end{array}$ & Grossa & aMédia & Fina & $\begin{array}{c}\text { Muito } \\
\text { fina }\end{array}$ & Total & Silte & Argila & Total \\
\hline 1 & 3,49 & 2,97 & MPS & Areia síltica & 0,00 & 1,41 & 1,41 & 3,17 & 14,96 & 16,28 & 23,87 & 6,04 & 64,31 & 23,42 & 10,86 & 34,28 \\
\hline 2 & 4,33 & 2,96 & MPS & Areia síltica & 0,00 & 0,56 & 0,56 & 2,85 & 7,73 & 10,50 & 15,20 & 11,50 & 47,77 & 45,86 & 5,80 & 51,66 \\
\hline 3 & 4,00 & 2,83 & MPS & Areia síltica & 0,00 & 0,83 & 0,83 & 3,26 & 10,19 & 13,65 & 20,44 & 8,94 & 56,49 & 31,50 & 11,18 & 42,68 \\
\hline 4 & 3,44 & 2,89 & MPS & Areia síltica & 0,00 & 1,35 & 1,35 & 2,51 & 16,55 & 17,50 & 21,21 & 9,92 & 67,69 & 19,21 & 11,75 & 30,96 \\
\hline 5 & 4,80 & 2,49 & MPS & Silte arenoso & 0,00 & 0,15 & 0,15 & 2,08 & 5,15 & 7,56 & 12,27 & 9,88 & 36,95 & 57,08 & 5,81 & 62,90 \\
\hline 6 & 4,67 & 2,32 & MPS & Silte arenoso & 0,00 & 1,75 & 1,75 & 2,04 & 6,90 & 7,94 & 10,96 & 7,44 & 35,29 & 56,88 & 6,09 & 62,97 \\
\hline 7 & 4,01 & 2,37 & MPS & Areia síltica & 0,00 & 0,99 & 0,99 & 1,20 & 11,39 & 12,09 & 18,97 & 8,66 & 52,31 & 38,52 & 8,17 & 46,70 \\
\hline 8 & 4,29 & 2,27 & MPS & Areia síltica & 0,00 & 0,05 & 0,05 & 0,96 & 6,22 & 15,76 & 15,61 & 12,91 & 51,45 & 42,65 & 5,85 & 48,50 \\
\hline 9 & 4,20 & 2,94 & MPS & Areia síltica & 0,00 & 0,32 & 0,32 & 0,83 & 8,44 & 15,89 & 17,24 & 7,76 & 50,16 & 43,72 & 5,80 & 49,51 \\
\hline 10 & 5,04 & 2,34 & MPS & Silte arenoso & 0,00 & 1,78 & 1,78 & 1,08 & 3,45 & 6,43 & 3,88 & 14,55 & 29,40 & 62,26 & 6,56 & 68,82 \\
\hline Máximo & 5,04 & 2,97 & & & 0,00 & 1,78 & 1,78 & 3,26 & 16,55 & 17,50 & 23,87 & 14,55 & 67,69 & 62,26 & 11,75 & 68,82 \\
\hline Mínimo & 3,44 & 2,27 & & & 0,00 & 0,05 & 0,05 & 0,83 & 3,45 & 6,43 & 3,88 & 6,04 & 29,40 & 19,21 & 5,80 & 30,96 \\
\hline Média & 4,23 & 2,64 & & & 0,00 & 0,92 & 0,92 & 2,00 & 9,10 & 12,36 & 15,97 & 9,76 & 49,18 & 42,11 & 7,79 & 49,90 \\
\hline Desvio-padrão & 0,52 & 0,29 & & & 0,00 & 0,61 & 0,61 & 0,89 & 3,99 & 3,86 & 5,53 & 2,47 & 11,73 & 13,66 & 2,38 & 11,70 \\
\hline
\end{tabular}

Há predomínio de sedimentos arenolamosos na região, sendo classificados segundo Shepard (1954) como areia síltica e silte arenoso (Fig. 14 A), e de acordo com sua seleção, são considerados muito pobremente selecionados (Folk e Ward, 1957). As estações 1, 2, 3, 4, 7, 8 e 9 apresentam maiores porcentagens de areia síltica, enquanto que os pontos 5, 6 e 10 possuem maior contribuição de silte arenoso.

As maiores porcentagens de areia são encontradas na desembocadura do emissário (\#1), a 100 m (\#2 e \#4) e 200 m à lesta da mesma (\#3, \#7 e \#8) (Fig. 14 B). Já as maiores porcentagens de sedimentos lamosos ocorrem nas estações localizadas a oeste da malha amostral (\#5, \#6 e \#10). Enquanto o ponto 4 apresenta a maior quantidade de areia e o ponto 10 a menor, ocorre o inverso em relação aos sedimentos lamosos. Grânulos ocorrem em pequenas porcentagens (1-2\%) e estão ausentes nas estações 5, 8, 9 e 10. Verifica-se que na porção areia, a fração de areia fina é a mais representativa, assim como a fração silte dentre os pelíticos. 


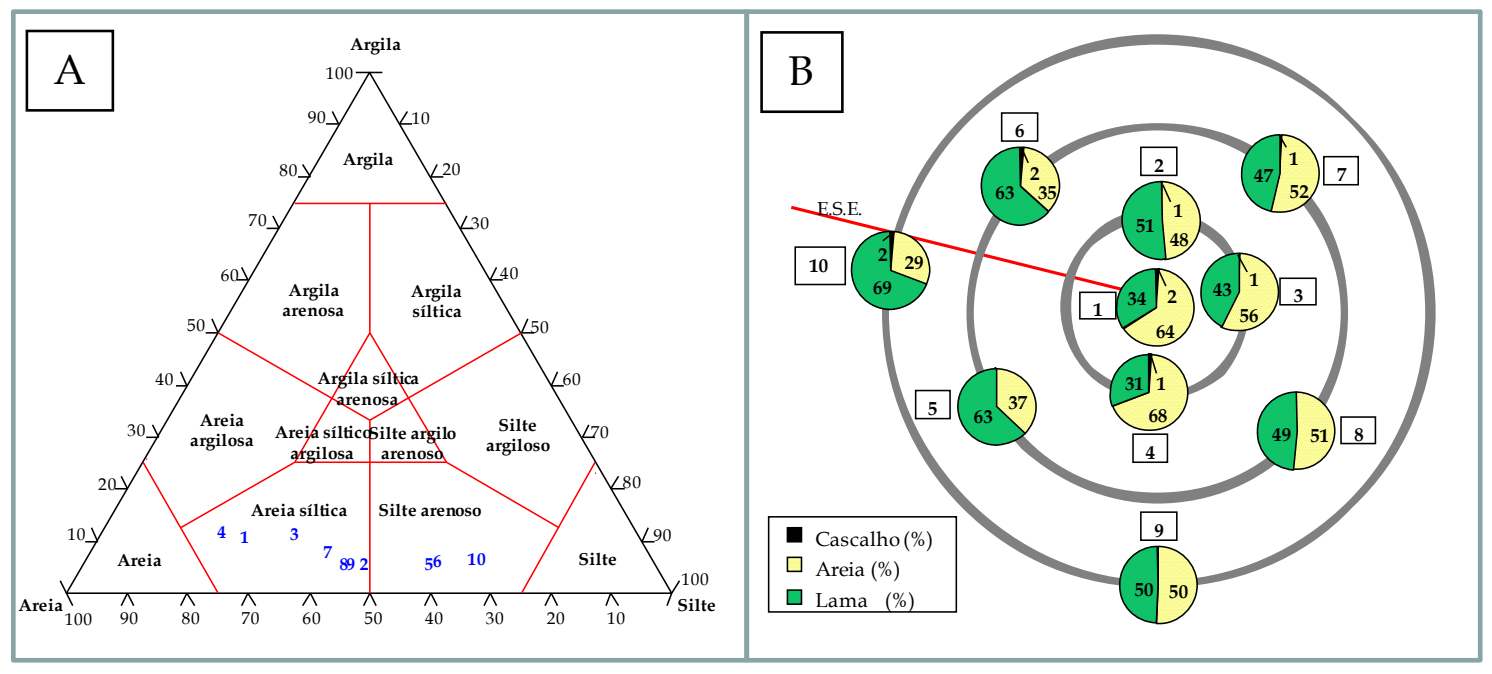

Figura 14: A: Classificação granulométrica por Shepard (1954). B: Granulometria dos sedimentos de 2006. E.S.E.= emissário submarino de esgoto.

\subsubsection{Parâmetros Geoquímicos}

Os dados geoquímicos dos nutrientes e do enxofre encontram-se na tabela 02 .

Tabela 02. Dados geoquímicos dos nutrientes dos sedimentos de 2006. $\mathrm{CaCO}_{3}=$ carbonato de cálcio; $S=$ enxofre total; Corg= carbono orgânico; $N=$ nitrogênio total.

\begin{tabular}{|cccccccc|}
\hline Estação & $\begin{array}{c}\text { CaCO3 } \\
(\mathbf{\%})\end{array}$ & $\begin{array}{c}\text { Classificação dos sedimentos } \\
\text { (Larsonneur , 1977) }\end{array}$ & $\begin{array}{c}\mathbf{S} \\
\mathbf{( \% )}\end{array}$ & $\begin{array}{c}\mathbf{C} \text { org } \\
\mathbf{( \% )}\end{array}$ & $\mathbf{C / S}$ & $\begin{array}{c}\mathbf{N} \\
\mathbf{( \% )}\end{array}$ & C/N \\
\hline $\mathbf{1}$ & 14,38 & Litoclástico & 0,22 & 0,83 & 3,74 & 0,25 & 3,32 \\
$\mathbf{2}$ & 18,07 & Litoclástico & 0,34 & 1,73 & 5,09 & 0,21 & 8,24 \\
$\mathbf{3}$ & 13,99 & Litoclástico & 0,27 & 1,16 & 4,31 & 0,22 & 5,27 \\
$\mathbf{4}$ & 13,06 & Litoclástico & 0,23 & 1,09 & 4,72 & 0,19 & 5,74 \\
$\mathbf{5}$ & 19,79 & Litoclástico & 0,40 & 2,14 & 5,34 & 0,22 & 9,73 \\
$\mathbf{6}$ & 20,63 & Litoclástico & 0,46 & 1,82 & 3,96 & 0,26 & 7,14 \\
$\mathbf{7}$ & 13,98 & Litoclástico & 0,33 & 1,17 & 3,60 & 0,13 & 9,00 \\
$\mathbf{8}$ & 13,92 & Litoclástico & 0,31 & 0,85 & 2,78 & 0,20 & 4,36 \\
$\mathbf{9}$ & 16,13 & Litoclástico & 0,34 & 1,58 & 4,69 & 0,15 & 10,53 \\
$\mathbf{1 0}$ & 22,16 & Litoclástico & 0,56 & 2,28 & 4,08 & 0,28 & 8,14 \\
\hline
\end{tabular}

De acordo com a classificação de Larssoneur, (1977), os pontos amostrais são classificados como litoclásticos, uma vez que apresentam quantidades de carbonato de cálcio inferiores a 30\%. O maior valor de carbonato de cálcio é encontrado na estação 10 $(22,16 \%)$ e o menor na estação $4(13,06 \%)$. 
As maiores porcentagens de carbono orgânico e enxofre são encontradas a oeste (\# 5,6 e 10) da desembocadura do emissário (Fig. 15). O menor teor de carbono ocorre no ponto $1(0,83 \%)$, enquanto que o 10 apresenta o maior valor (2,28\%). A menor porcentagem de enxofre ocorre na estação $1(0,22 \%)$ e a maior na estação $10(0,56 \%)$.

Em relação ao nitrogênio total, os menores valores estão localizados a 100 e 200 m ao sul da saída dos difusores e a $200 \mathrm{~m}$ a nordeste dos mesmos. Já os maiores teores encontram-se a oeste da malha amostral (\# 6 e 10). A estação 7 apresenta o menor valor $(0,13 \%)$ e a estação 10 o maior (0,28\%) (Fig. 15).

A razão C/S (carbono orgânico/ enxofre total) é calculada para classificar o ambiente em relação à oxigenação. A menor razão encontrada ocorre na estação $8(2,78)$ e a maior no ponto $5(5,34)$ (Fig. 15). Apesar dos pontos 2 e 5 apresentarem condições óxicas tanto na coluna d'água quanto nos sedimentos, o restante das estações apresenta deposições em períodos de anoxia.

Já a partir da razão $C / N$ (carbono orgânico/nitrogênio total) é possível inferir a origem da matéria orgânica (Fig. 15). Constata-se que metade dos pontos amostrais apresenta origem marinha, e o restante possui origem mista, ou seja, mistura entre matéria orgânica continental e marinha. O menor valor ocorre no ponto amostral $1(3,32)$, localizado na saída dos difusores, e o maior na estação $9(10,53)$. 


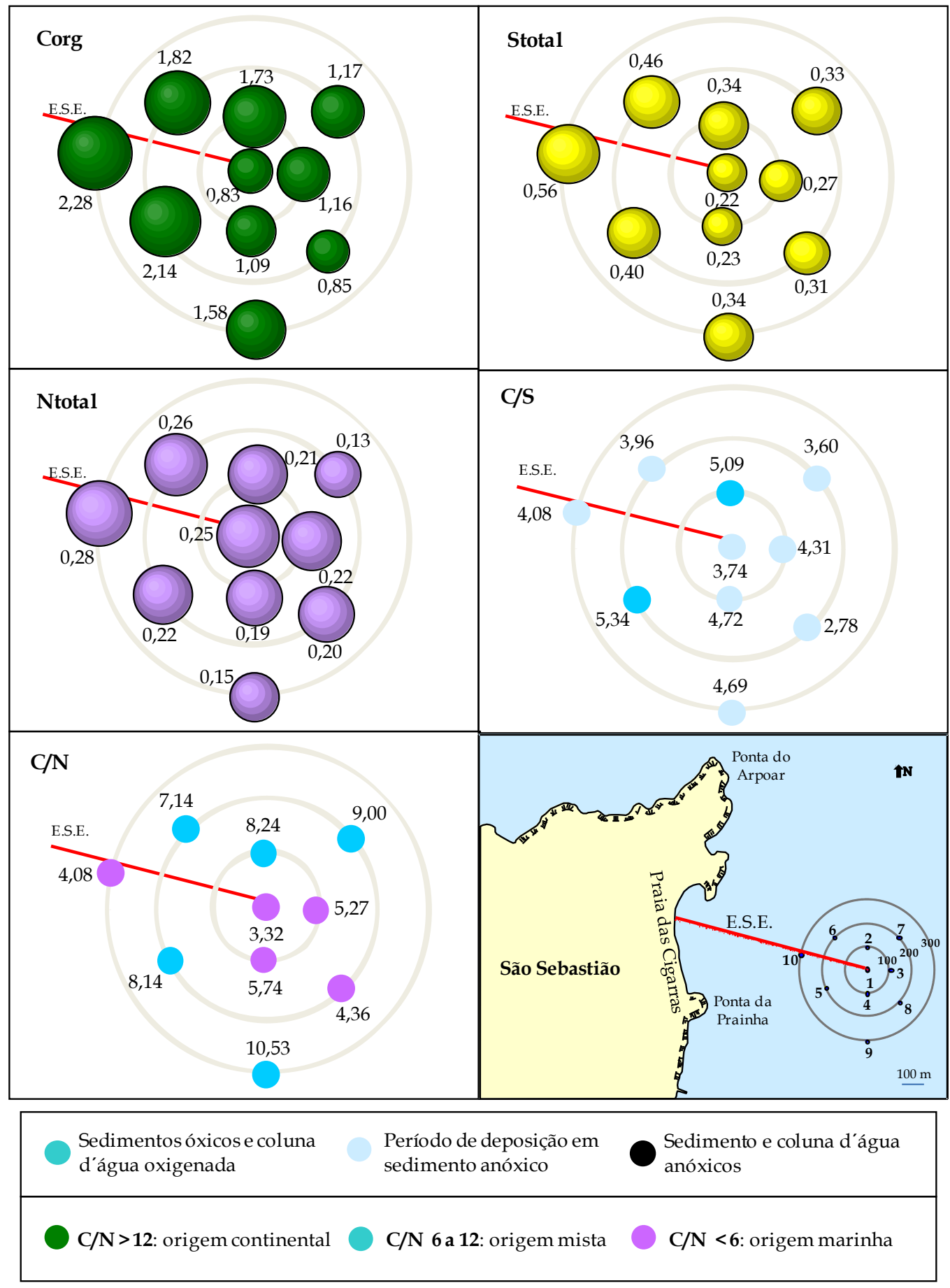

Figura 15: Porcentagens de carbono orgânico, enxofre total, nitrogênio total, razão $C / S$ e $C / N$ dos sedimentos de 2006. E.S.E.= emissário submarino de esgoto das Cigarras.

Os valores de hidrocarbonetos aromáticos policíclicos (HPAs) presentes nos sedimentos de 2006, assim como as taxas de recuperação dos surrogates utilizados nas análises encontram-se listados na tabela 03. Os dados de HPAs foram comparados com os 
critérios de qualidade estabelecidos pelo Canadá (CCME- Canadian Council of ministers of the Environment), dispostos no Anexo 05.

Tabela 03. Concentrações dos HPAs $(\mu \mathrm{g} / \mathrm{Kg})$ e taxas de recuperação dos surrogates utilizados nas análises de HPAs nos sedimentos de 2006. $\mathrm{LQ}=$ limite de quantificação em $\mu \mathrm{g} / \mathrm{Kg}$. Em negrito são os valores acima do limite de quantificação.

\begin{tabular}{|c|c|c|c|c|c|c|c|c|c|c|c|}
\hline Compostos & $\# 1$ & $\# 2$ & $\# 3$ & $\# 4$ & \# 5 & $\# 6$ & $\# 7$ & $\# 8$ & $\# 9$ & $\# 10$ & LQ \\
\hline Acenafteno & $<5,0$ & $<5,0$ & $<5,0$ & $<5,0$ & $<5,0$ & $<5,0$ & $<5,0$ & $<5,0$ & $<5,0$ & $<5,0$ & 5,0 \\
\hline Acenaftileno & $<5,0$ & $<5,0$ & $<5,0$ & $<5,0$ & $<5,0$ & $<5,0$ & $<5,0$ & $<5,0$ & $<5,0$ & $<5,0$ & 5,0 \\
\hline Antraceno & $<5,0$ & $<5,0$ & $<5,0$ & $<5,0$ & $<5,0$ & $<5,0$ & $<5,0$ & $<5,0$ & $<5,0$ & $<5,0$ & 5,0 \\
\hline Benzo(a)antraceno & $<5,0$ & $<5,0$ & $<5,0$ & $<5,0$ & $<5,0$ & $<5,0$ & $<5,0$ & $<5,0$ & $<5,0$ & $<5,0$ & 5,0 \\
\hline Benzo(a)pireno & $<5,0$ & $<5,0$ & $<5,0$ & $<5,0$ & $<5,0$ & $<5,0$ & $<5,0$ & $<5,0$ & $<5,0$ & $<5,0$ & 5,0 \\
\hline Benzo(b)fluoranteno & $<5,0$ & $<5,0$ & $<5,0$ & $<5,0$ & $<5,0$ & $<5,0$ & $<5,0$ & $<5,0$ & $<5,0$ & $<5,0$ & 5,0 \\
\hline Benzo(k)fluoranteno & $<5,0$ & $<5,0$ & $<5,0$ & $<5,0$ & $<5,0$ & $<5,0$ & $<5,0$ & $<5,0$ & $<5,0$ & $<5,0$ & 5,0 \\
\hline Benzo[g, $h, i]$ perileno & $<5,0$ & $<5,0$ & $<5,0$ & $<5,0$ & $<5,0$ & $<5,0$ & $<5,0$ & $<5,0$ & $<5,0$ & $<5,0$ & 5,0 \\
\hline Criseno & $<5,0$ & $<5,0$ & $<5,0$ & $<5,0$ & $<5,0$ & $<5,0$ & $<5,0$ & $<5,0$ & $<5,0$ & $<5,0$ & 5,0 \\
\hline Dibenzo[a, h]antraceno & $<5,0$ & $<5,0$ & $<5,0$ & $<5,0$ & $<5,0$ & $<5,0$ & $<5,0$ & $<5,0$ & $<5,0$ & $<5,0$ & 5,0 \\
\hline Fenantreno & $<5,0$ & $<5,0$ & $<5,0$ & $<5,0$ & $<5,0$ & $<5,0$ & $<5,0$ & $<5,0$ & $<5,0$ & $<5,0$ & 5,0 \\
\hline Fluoranteno & $<5,0$ & $<5,0$ & $<5,0$ & $<5,0$ & $<5,0$ & 5,9 & $<5,0$ & $<5,0$ & $<5,0$ & $<5,0$ & 5,0 \\
\hline Fluoreno & $<5,0$ & $<5,0$ & $<5,0$ & $<5,0$ & $<5,0$ & $<5,0$ & $<5,0$ & $<5,0$ & $<5,0$ & $<5,0$ & 5,0 \\
\hline Indeno[1, 2,3-cd]pireno & $<5,0$ & $<5,0$ & $<5,0$ & $<5,0$ & $<5,0$ & $<5,0$ & $<5,0$ & $<5,0$ & $<5,0$ & $<5,0$ & 5,0 \\
\hline Naftaleno & 8,9 & $<5,0$ & 5,7 & $<5,0$ & $<5,0$ & $<5,0$ & $<5,0$ & $<5,0$ & $<5,0$ & $<5,0$ & 5,0 \\
\hline Pireno & $<5,0$ & $<5,0$ & $<5,0$ & $<5,0$ & $<5,0$ & 5,3 & $<5,0$ & $<5,0$ & $<5,0$ & $<5,0$ & 5,0 \\
\hline \multirow{2}{*}{ Surrogates } & \multicolumn{8}{|c|}{ Resultado de recuperação (\%) } & \multirow{2}{*}{\multicolumn{3}{|c|}{$\begin{array}{c}\text { Limite de controle } \\
\text { de qualidade }(\%)\end{array}$}} \\
\hline & \multicolumn{2}{|c|}{ Mínimo } & \multicolumn{2}{|c|}{ Máximo } & \multicolumn{2}{|c|}{ Média } & \multicolumn{2}{|c|}{ Desvio-padrão } & & & \\
\hline 2-Fluorobifenil & \multirow{2}{*}{\multicolumn{2}{|c|}{$\begin{array}{l}37 \\
45\end{array}$}} & \multicolumn{2}{|c|}{59} & \multicolumn{2}{|c|}{43,2} & \multicolumn{2}{|c|}{6,6} & \multicolumn{3}{|c|}{$24-111$} \\
\hline Terfenil-d14 & & & & & & & & & \multicolumn{3}{|c|}{$25-110$} \\
\hline
\end{tabular}

Verifica-se que a maioria das concentrações obtidas nas estações para todos os HPAs são inferiores ao limite de quantificação $(>5 \mu \mathrm{g} / \mathrm{Kg})$. Os únicos HPAs que apresentam valores quantificáveis são o Naftaleno $(8,9 \mu \mathrm{g} / \mathrm{Kg}$ na \#1 e 5,7 $\mu \mathrm{g} / \mathrm{Kg}$ na \# 3), Fluoranteno $(5,9 \mu \mathrm{g} / \mathrm{Kg}$ na \# 6) e Pireno $(5,3 \mu \mathrm{g} / \mathrm{Kg}$ na \# 6). As taxas de recuperação de ambos surrogates usados na análise estão dentro do limite de qualidade.

\subsubsection{Análise dos Foraminíferos}

\subsection{4.a Tanatocenose}

Os gêneros e espécies encontrados na área de estudo estão listados no Anexo 02, com suas devidas frequências relativas e com os índices de diversidade de Shannon $\left(\mathrm{H}^{\prime}\right)$ e equitatividades $\left(\mathrm{E}_{\mathrm{H}}\right)$. As fotomicrografias de alguns exemplares estão dispostas nas pranchas 1 e 2 no Anexo 08. 
Há ocorrência de 24 gêneros e 36 espécies de foraminíferos nas amostras, sendo todos bentônicos. As densidades variam entre 600 (\# 5) a 1368 indivíduos. $10 \mathrm{cc}^{-1}$ (\# 7) (Fig. 16 A). As maiores riquezas são encontradas nas estações 1, 3, 6, 7 e 8, com 21 espécies, e a menor no ponto 4, com 15 espécies (Fig. 16 B).

Há representantes das três principais subordens de foraminíferos, porém a subordem Rotaliina constitui mais de 94\% dos indivíduos (Fig. 16 C). As subordens Miliolina e Textulariina ocorrem em apenas algumas estações e com pequenas contribuições (Fig. 16 D e E).

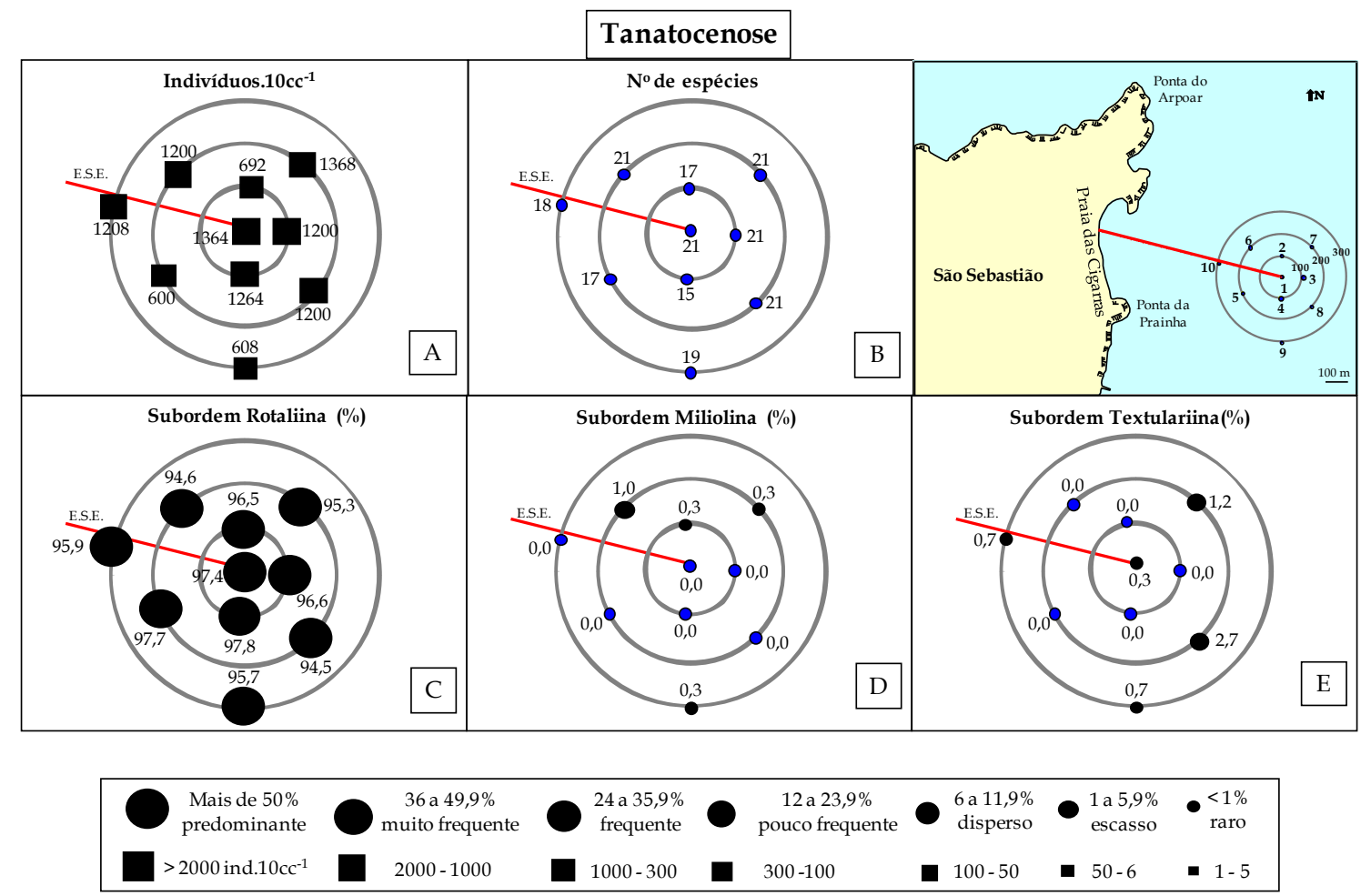

Figura 16: A: densidade, B: riqueza. C, D e E: frequência relativa das subordens da tanatocenose em 2006. E.S.E.= emissário submarino de esgoto das Cigarras.

O gênero predominante nas amostras é Ammonia, sendo sua menor porcentagem na estação $8(37,3 \%)$ e a maior na estação 5 (65\%). A A. tepida é a espécie mais representativa nas amostras, com exceção da estação 8 , sendo seguida decrescentemente pela $P$. cananeiaensis e A. parkinsoniana. Os grupos dos cribroelfidiuns e das bolivinas ocorrem em todos os pontos amostrais, porém em menor quantidade. 
A estação 8 apresenta a maior diversidade $\left(H^{\prime}=2,60\right)$ e homogeneidade na distribuição das espécies entre seus indivíduos $\left(E_{H}=0,85\right)$. Já a estação 5 é a de menor diversidade $\left(\mathrm{H}^{\prime}=1,93\right)$ e apresenta a distribuição mais heterogênea dos seus indivíduos entre as diferentes espécies $\left(E_{H}=0,68\right)$.

A análise morfométrica revela predomínio de carapaças médias (125-250 $\mu \mathrm{m})$ na região, tendo sua menor contribuição no ponto $9(65 \%)$ e as maiores porcentagens encontram-se na estação 3 (79\%) (Fig. 17). Carapaças pequenas $(<125 \mu \mathrm{m})$ e grandes $(250$ $500 \mu \mathrm{m}$ ) estão presentes em todos os pontos, com valores que oscilam entre $14 \%$ (\#3) a 30\%

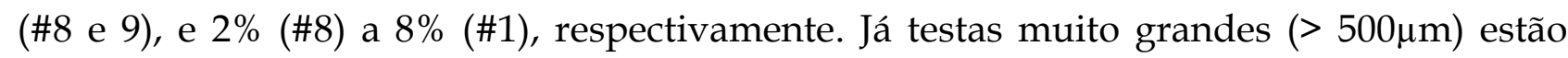
ausentes.

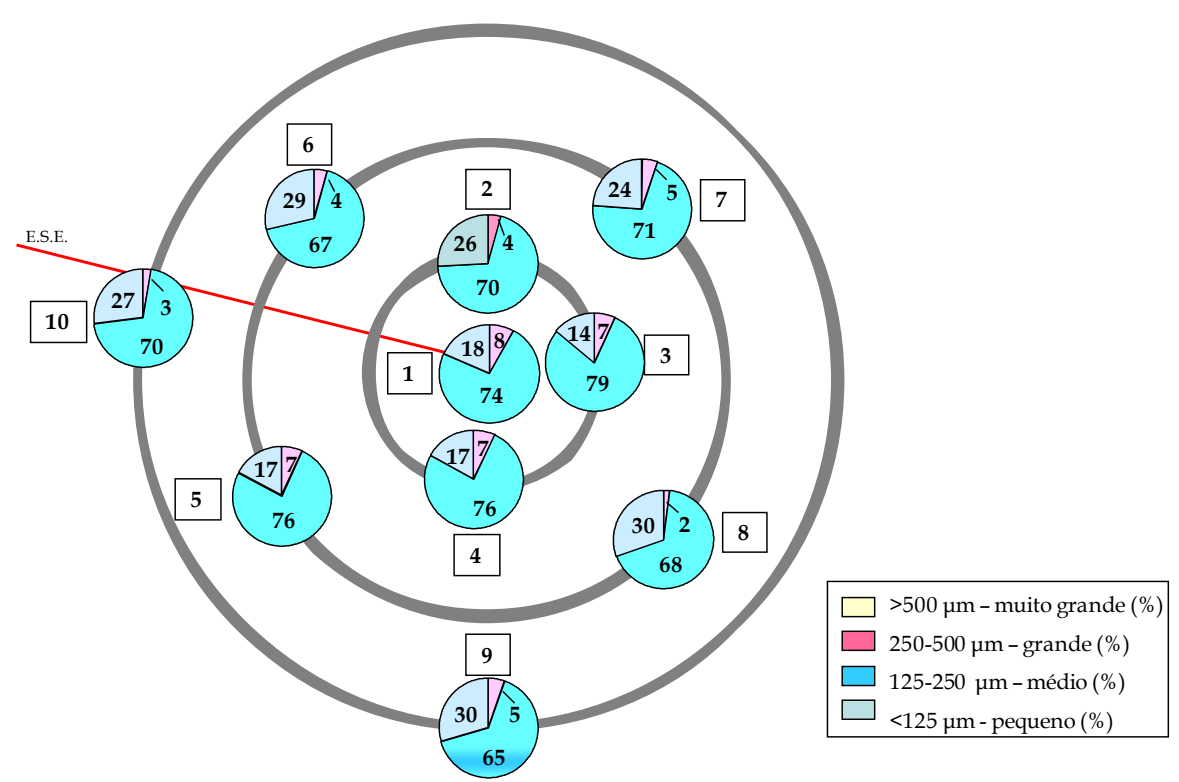

Figura 17: Morfometria das carapaças da tanatocenose de 2006. E.S.E.= emissário submarino de esgoto das Cigarras.

A partir da análise tafonômica observa-se que as testas parcialmente fragmentadas constituem a maioria, apresentando valores que oscilam entre 54\% (\#6) e 72\% (\#3) das carapaças totais (Fig. 18). As inteiras perfazem de 23\% (\#3) a 43\% (\#6), enquanto que os fragmentos variam entre 1\% (\#1, \#4 e \#10) e 5\% (\#3). 


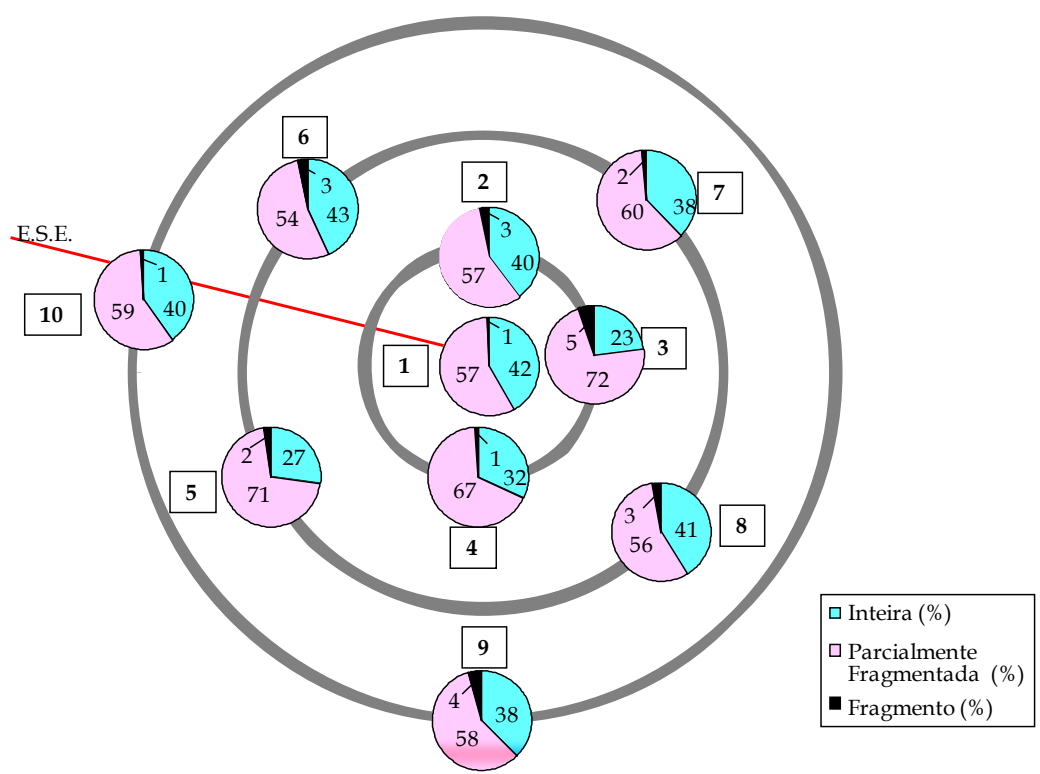

Figura 18: Análise tafonômica das carapaças da tanatocenose de 2006. E.S.E.= emissário submarino de esgoto das Cigarras.

As carapaças de coloração normal são majoritárias e perfazem acima de $90 \%$ dos foraminíferos (Fig. 19). Tecas limonitizadas ocorrem em todas as estações com contribuições de 1\% a 3\%. Testas com pirita estão ausentes nas estações 3, 4, 6 e 9, e nas demais apresentam porcentagens que oscilam entre 1 e $4 \%$ das amostras. Já carapaças preenchidas com monossulfeto de ferro ocorrem em todas as estações, com exceção do ponto 3 , com valores entre 1 e $4 \%$.

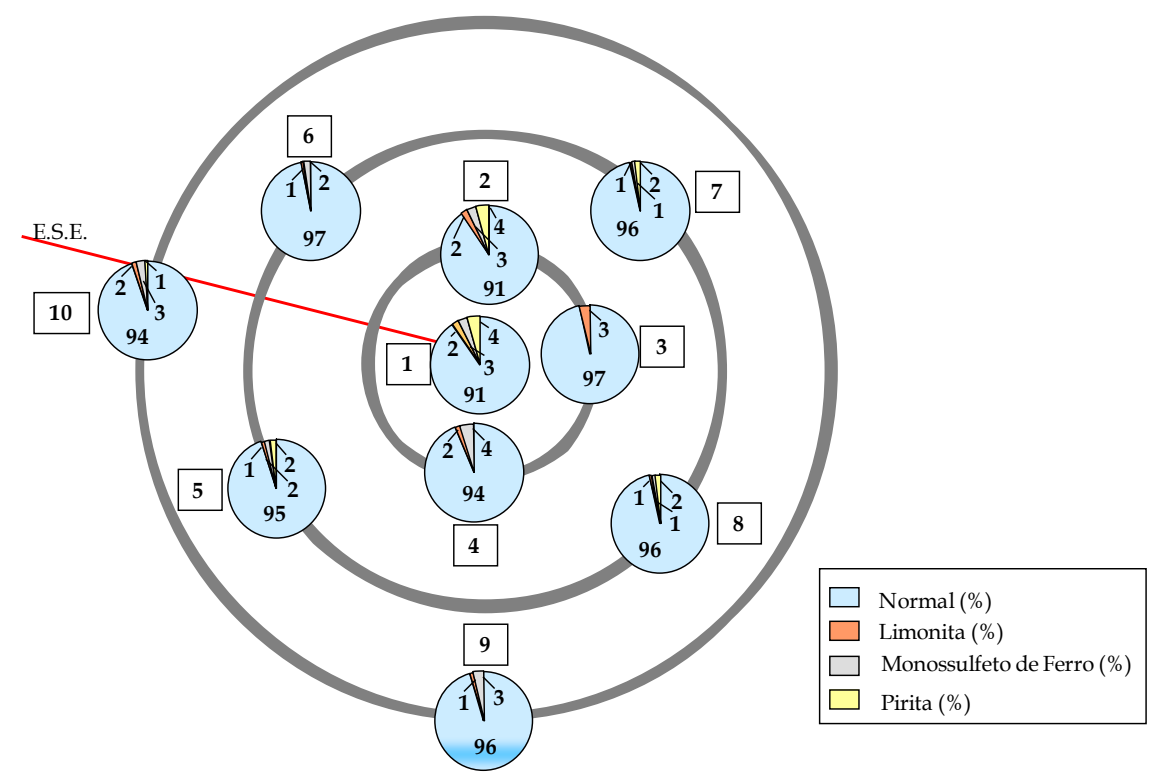

Figura 19: Coloração das carapaças da tanatocenose de 2006. E.S.E.= emissário submarino de esgoto das Cigarras. 
Indicadores de ambiente rico em matéria orgânica e em oxigênio estão listados na tabela 04, com suas devidas frequências relativas.

Tabela 04. Frequência relativa dos gêneros e das espécies mortas indicadoras de matéria orgânica e de ambiente rico em oxigênio de 2006.

\begin{tabular}{|c|c|c|c|c|c|c|c|c|c|c|c|}
\hline & $\begin{array}{c}\text { Estação } \\
\text { M= mortos }\end{array}$ & $\begin{array}{c}1 \\
\text { M \% } \\
\end{array}$ & $\begin{array}{c}2 \\
\mathrm{M} \% \\
\end{array}$ & $\begin{array}{c}3 \\
\mathrm{M} \% \\
\end{array}$ & $\begin{array}{c}4 \\
\mathrm{M} \% \\
\end{array}$ & $\begin{array}{c}5 \\
\mathrm{M} \% \\
\end{array}$ & $\begin{array}{c}6 \\
\text { M \% } \\
\end{array}$ & $\begin{array}{c}7 \\
\text { M \% } \\
\end{array}$ & $\begin{array}{c}8 \\
\text { M \% } \\
\end{array}$ & $\begin{array}{c}9 \\
\mathrm{M} \% \\
\end{array}$ & $\begin{array}{c}10 \\
\text { M \% } \\
\end{array}$ \\
\hline \multirow{23}{*}{ 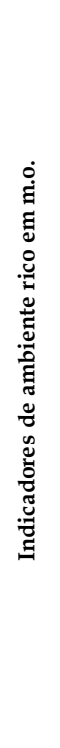 } & Ammoscalaria sp. & 0,0 & 0,0 & 0,0 & 0,0 & 0,0 & 0,0 & 0,3 & 0,7 & 0,0 & 0,4 \\
\hline & Bolivina compacta & 0,9 & 0,6 & 0,0 & 0,0 & 0,0 & 0,0 & 0,0 & 0,0 & 0,0 & 0,0 \\
\hline & Bolivina danvillensis & 0,0 & 0,0 & 0,0 & 0,0 & 0,0 & 0,0 & 0,0 & 1,0 & 0,0 & 0,4 \\
\hline & Bolivina doniezi & 1,2 & 0,0 & 0,7 & 0,0 & 1,0 & 0,0 & 0,3 & 0,7 & 0,0 & 0,4 \\
\hline & Bolivina ordinaria & 1,8 & 0,0 & 0,7 & 0,6 & 0,3 & 0,3 & 0,3 & 0,3 & 1,0 & 0,4 \\
\hline & Bolivina pulchella & 5,0 & 3,8 & 2,7 & 2,2 & 3,7 & 1,3 & 2,0 & 2,7 & 3,3 & 1,4 \\
\hline & Bolivina sp. & 1,5 & 0,6 & 0,0 & 0,6 & 0,0 & 1,0 & 0,6 & 0,3 & 1,0 & 0,4 \\
\hline & Buccella peruviana & 0,0 & 0,0 & 0,3 & 0,0 & 0,0 & 0,0 & 0,3 & 0,0 & 0,0 & 0,0 \\
\hline & Bulimina marginata & 1,8 & 2,0 & 3,1 & 1,9 & 1,7 & 1,0 & 1,5 & 2,3 & 2,3 & 1,4 \\
\hline & Bulimina pupoides & 0,3 & 0,0 & 1,0 & 0,0 & 0,7 & 0,0 & 0,0 & 0,0 & 0,0 & 0,0 \\
\hline & Bulimina sp. & 0,6 & 0,6 & 0,3 & 0,0 & 0,0 & 0,0 & 0,6 & 0,3 & 0,3 & 0,0 \\
\hline & Buliminella elegantissima & 0,9 & 0,0 & 1,0 & 0,6 & 0,0 & 2,3 & 1,2 & 3,0 & 1,0 & 1,4 \\
\hline & Brizalina striatula & 2,1 & 1,4 & 1,0 & 1,3 & 1,0 & 0,0 & 0,6 & 0,7 & 1,3 & 0,4 \\
\hline & Cassidulina crassa & 0,9 & 1,2 & 1,0 & 0,9 & 0,3 & 0,7 & 0,6 & 1,0 & 0,3 & 1,1 \\
\hline & Cassidulina laevigata & 0,0 & 0,3 & 0,0 & 0,0 & 0,0 & 0,0 & 0,0 & 0,0 & 0,3 & 0,0 \\
\hline & Cassidulina minuta & 0,0 & 0,0 & 0,0 & 0,0 & 0,0 & 0,3 & 0,0 & 0,0 & 0,0 & 0,0 \\
\hline & Cassidulina subglobosa & 0,0 & 0,0 & 0,0 & 0,0 & 0,0 & 0,0 & 0,3 & 0,0 & 0,0 & 0,4 \\
\hline & Cassidulina sp. & 0,0 & 0,3 & 0,0 & 0,0 & 0,0 & 0,3 & 0,0 & 0,0 & 0,3 & 0,0 \\
\hline & Hopkinsina pacifica & 0,0 & 0,0 & 0,0 & 0,0 & 0,0 & 0,3 & 0,0 & 0,0 & 0,0 & 0,0 \\
\hline & Pseudononion atlanticum & 5,3 & 2,6 & 1,7 & 2,2 & 1,0 & 2,0 & 2,9 & 3,0 & 3,3 & 1,1 \\
\hline & Pseudononion sp. & 0,0 & 0,0 & 2,4 & 0,0 & 0,7 & 0,0 & 0,0 & 1,3 & 0,7 & 1,1 \\
\hline & Uvigerina peregrina & 0,3 & 0,0 & 0,0 & 0,0 & 0,0 & 0,3 & 0,0 & 0,0 & 0,0 & 0,0 \\
\hline & Total & 22,3 & 13,3 & 15,9 & 10,4 & 10,3 & 10,0 & 11,4 & 17,3 & 15,1 & 9,9 \\
\hline \multicolumn{12}{|l|}{ : ปี } \\
\hline \multirow{4}{*}{ 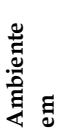 } & Discorbis williamsoni & 0,0 & 0,0 & 0,0 & 0,0 & 0,0 & 0,0 & 0,3 & 0,0 & 0,0 & 0,0 \\
\hline & Hanzawaia bouena & 0,9 & 0,0 & 0,3 & 0,0 & 0,0 & 0,7 & 0,0 & 0,7 & 1,0 & 0,0 \\
\hline & Neocornobina terquemi & 0,3 & 0,3 & 0,0 & 0,0 & 0,0 & 0,3 & 0,0 & 0,0 & 0,0 & 0,4 \\
\hline & Total & 1,2 & 0,3 & 0,3 & 0,0 & 0,0 & 1,0 & 0,3 & 0,7 & 1,0 & 0,4 \\
\hline
\end{tabular}

Indicadores totais de matéria orgânica estão presentes em todos os pontos amostrais de forma acessória, sendo representados por 10 gêneros e 17 espécies (Fig. 20). Há 4 grupos mais representativos, citados em ordem decrescente: Bolivina spp., Pseudononion spp., Bulimina spp. e B. elegantissima. O primeiro grupo predomina em todas as estações, exceto no ponto 3, onde há predomínio de buliminas. Espécimes de $B$. elegantissima estão ausentes nas estações 2 e 5. Em menor frequência ocorrem indivíduos de Cassidulina spp., B. striatula, Ammoscalaria sp., B. peruviana, U. peregrina e H. pacifica. 


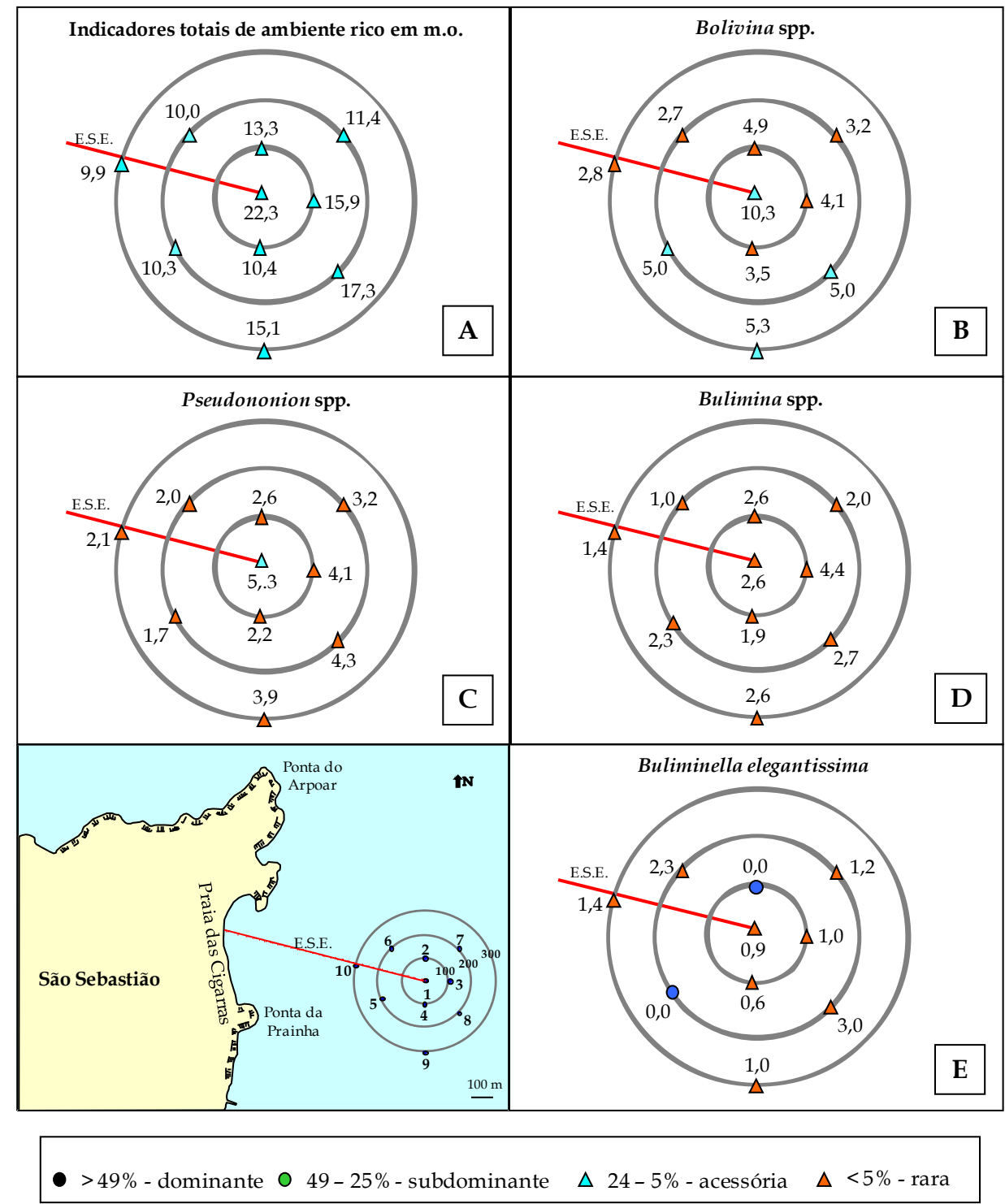

Figura 20: A: Frequência relativa total dos indicadores de matéria orgânica (m.o.). B, C, D e E: indicadores de m.o. mais representativos de 2006. E.S.E.= emissário submarino de esgoto das Cigarras.

Indicadores de oxigênio não estão presentes nas estações 4 e 5 e ocorrem de forma rara nos demais pontos amostrais, sendo compostos por apenas 3 espécies (Fig. 21). A estação 1 apresenta a maior quantidade desses indicadores. A espécie mais representativa é a H. boueana, seguida pela N. terquemi. Representantes de D. williamsoni ocorrem apenas no ponto 7. 


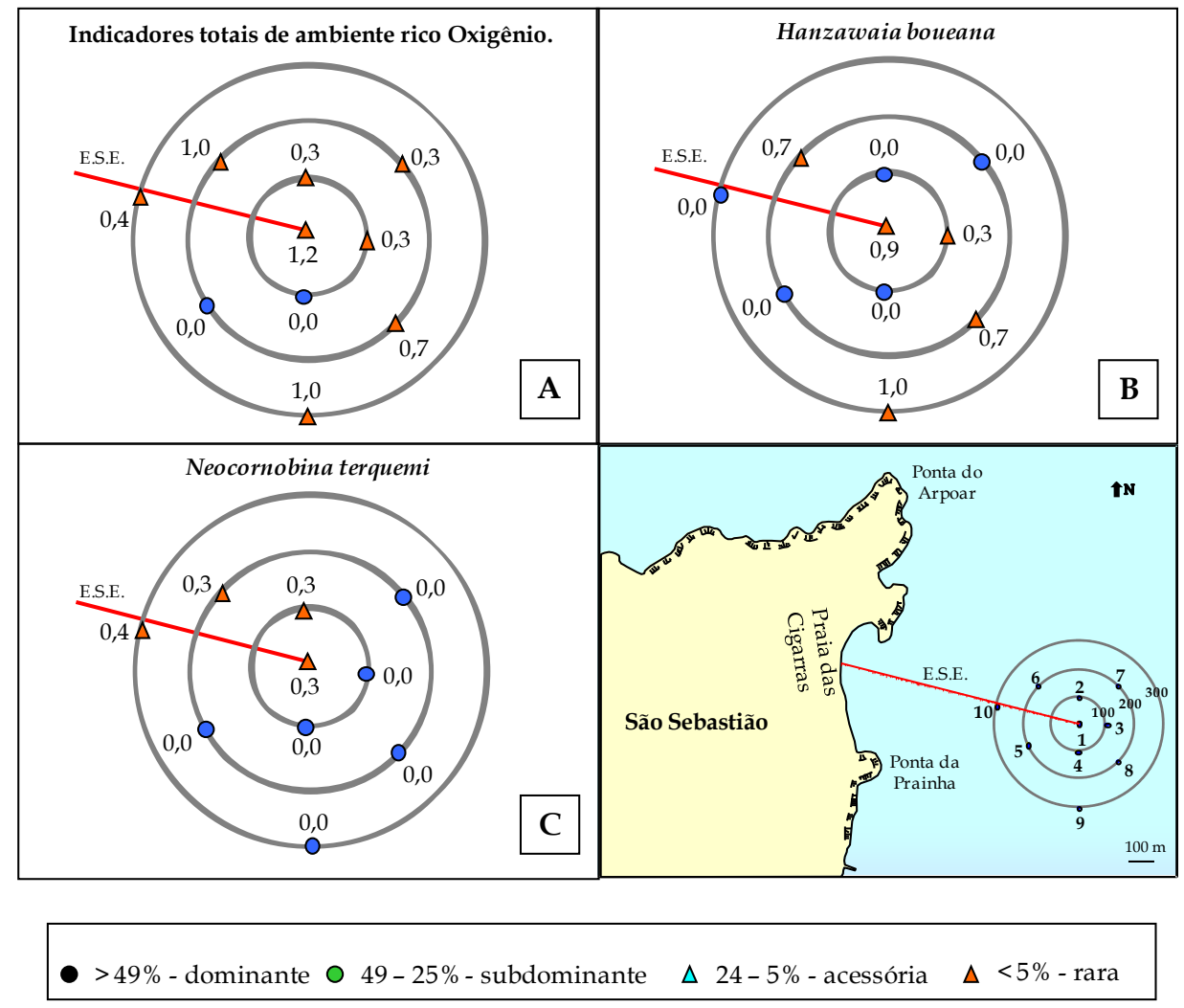

Figura 21: A: Frequência relativa total dos indicadores de oxigênio. B e C: indicadores de oxigênio mais representativos de 2006. E.S.E.= emissário submarino de esgoto das Cigarras.

A análise de agrupamento numérica (modo Q) revela a formação de 3 grupos (Fig. 22). O primeiro é constituído pelas estações 1, 7, 4 e 3, localizadas a 100 e $200 \mathrm{~m}$ de distância da saída dos difusores a sul e leste. O segundo consiste nos pontos 5, 6 e 2, localizados a $100 \mathrm{~m}$ sentido norte dos difusores e $200 \mathrm{~m}$ sentido oeste. Já o terceiro é formado pelas estações 8, 9 e 10 que distam $200 \mathrm{~m}$ a sudeste, $300 \mathrm{~m}$ ao sul e $300 \mathrm{~m}$ à oeste da saída do emissário. Os grupos 1 e 2 apresentam dissimilaridade inferior entre si do que em relação ao grupo 3 . 


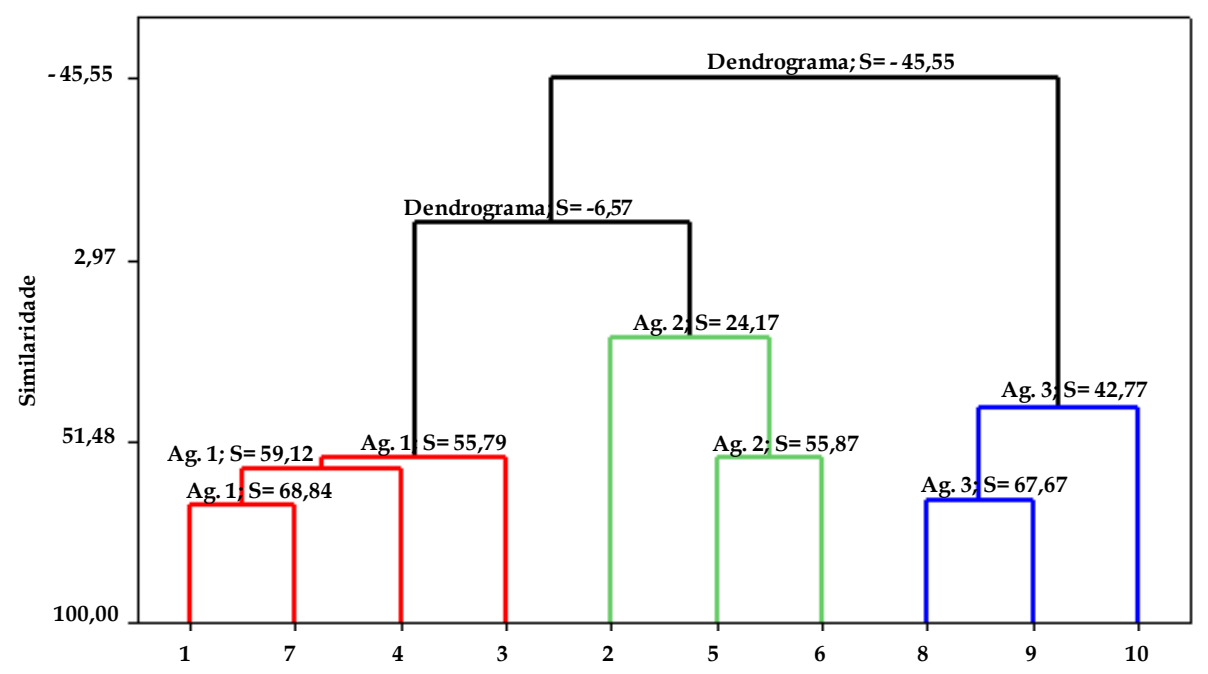

Figura 22: Análise de agrupamento numérica (modo Q) de 2006. Ag.= agrupamento.

A análise inversa (modo R) agrupou as espécies mais representativas em 2 associações (Fig. 23). A primeira associação apresenta similaridade de 58,58\% e é constituída por A. parkinsoniana, R. rolshauseni e A. tepida que são euribióticos, ou seja, que apresentam capacidade de sobreviver a amplas variações ambientais, sendo, portanto considerados como oportunistas em relação as demais espécies.

Já a segunda associação, com similaridade de 26,04\%, é constituída por 2 subgrupos. O subgrupo A é formado por indicadores de matéria orgânica (B. pulchella, B. marginata e $P$. atlanticum), de ambiente costeiro (C. poyeanum) e de influência marinha $(P$. cananeiaensis). Já o subgrupo B é constituído apenas por espécies costeiras (C. advenum e C. excavatum). Há dissimilaridade entre o agrupamento 1 e o 2 de $-29,86 \%$.

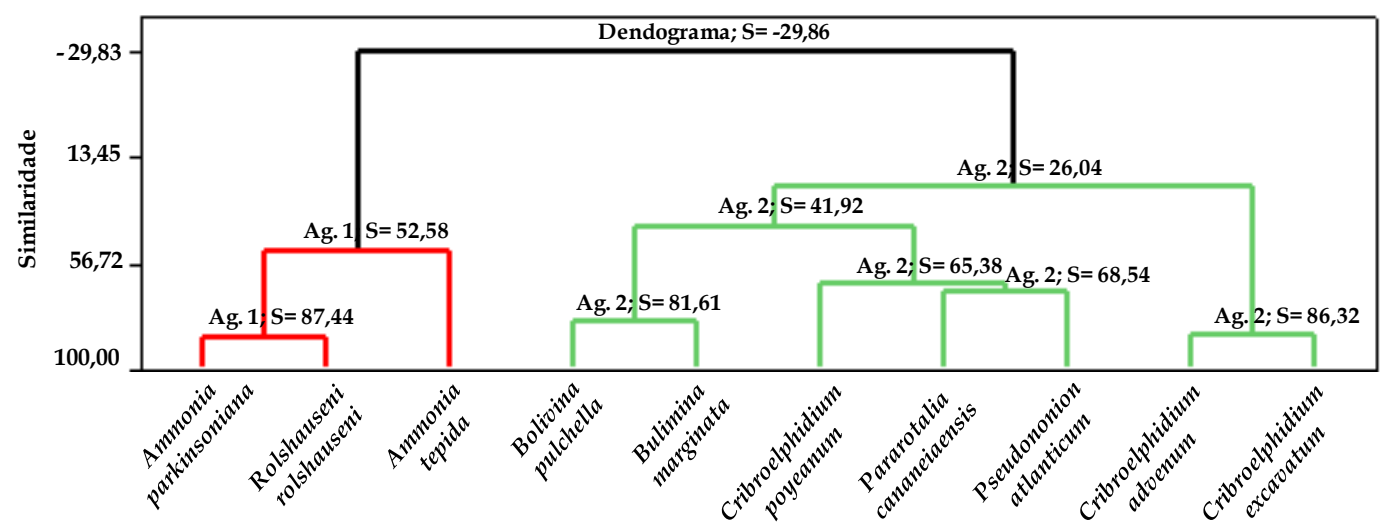

Figura 23: Análise de agrupamento inversa (modo R) de 2006. Ag.= agrupamento. 


\subsection{4.b Biocenose}

Os gêneros e espécies encontrados na região circunjacente ao emissário submarino de esgoto das Cigarras estão listados com suas devidas frequências relativas e com os índices de diversidade de Shannon $\left(\mathrm{H}^{\prime}\right)$ e equitatividades $\left(\mathrm{E}_{\mathrm{H}}\right)$ no Anexo 02.

Há ocorrência de 20 gêneros e 26 espécies de foraminíferos nas amostras, sendo todos bentônicos. As densidades variam de 65 (\#2) a 215 indivíduos. 10 cc-1 (\#4) (Fig. 24 A). As maiores riquezas ocorrem nos pontos 4 e 7, com 14 espécies, enquanto que a menor encontra-se no ponto 6, com apenas 4 espécies (Fig. 24 B).

As estações possuem representantes das três principais subordens de foraminíferos, sendo que a Rotaliina constitui mais de 94\% dos indivíduos (Fig. 24 C). As subordens Miliolina e Textulariina ocorrem em pequenas porcentagens, e apenas em algumas estações, com contribuições máximas de $2 \%$ e 0,8\%, respectivamente (Fig. 24 D e E).

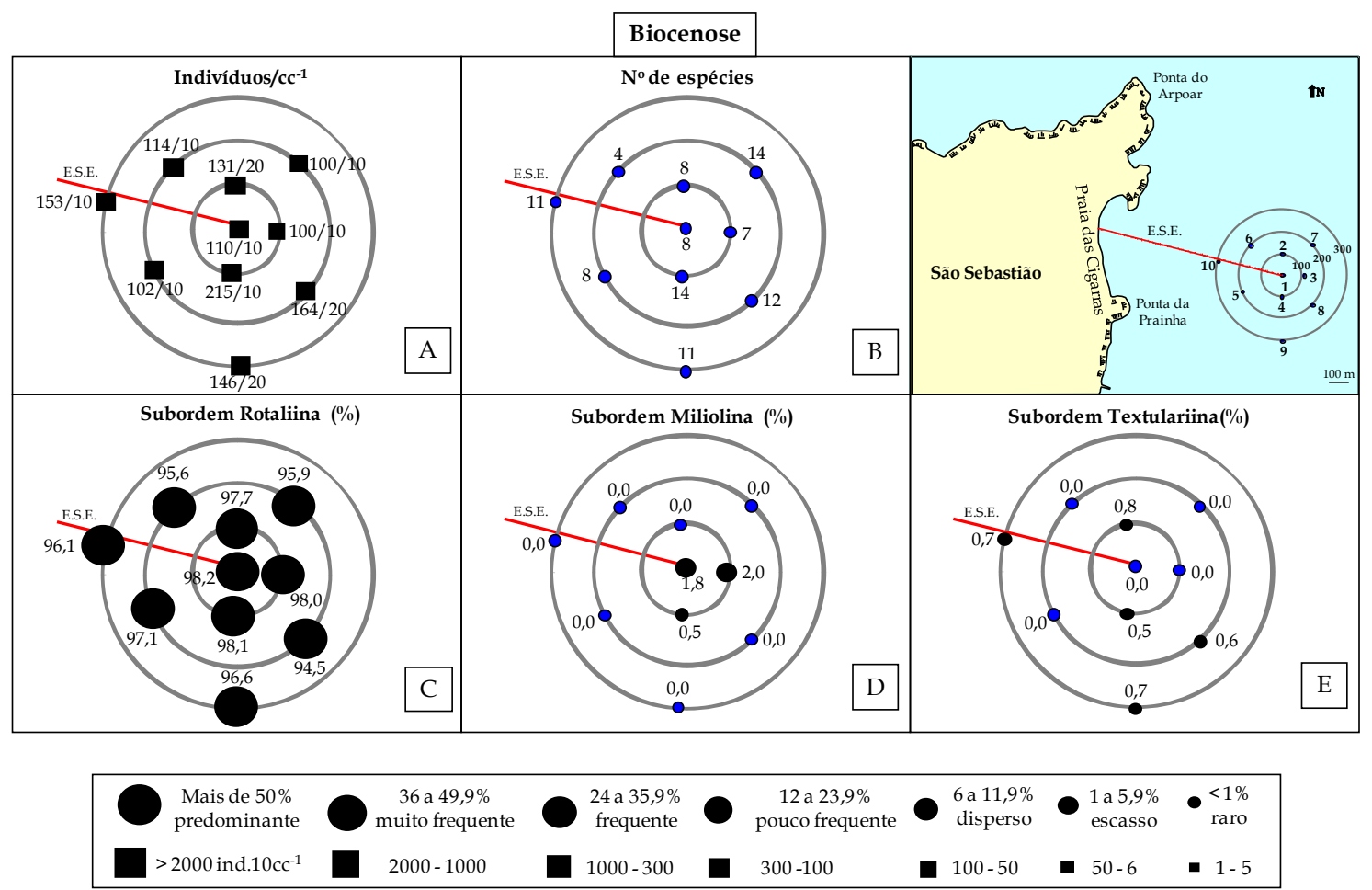

Figura 24: A: densidade, B: riqueza. Frequência relativa das subordens da biocenose $(C, D$ e $E)$ de 2006. E.S.E.= emissário submarino de esgoto das Cigarras. 
O gênero predominante nas amostras é Ammonia, sendo sua menor porcentagem $72,4 \%$ (\# 3) e a maior $89,5 \%$ (\# 6). A espécie mais representativa é a A. tepida, sendo menos frequente na estação 10 (47,1\%) e mais frequente na estação 1 (76,4\%). A A. parkinsoniana é a segunda espécie mais numerosa, apresentando porcentagens de até 33,3\% (\#10). Em seguida ocorre a B. striatula que corresponde a até $9,2 \%$ dos indivíduos no ponto 3. Já os grupos das bolivinas e cribroelfidiuns também estão presentes nas amostras, porém em menores quantidades.

A estação 7 é a mais diversificada $\left(H^{\prime}=1,73\right)$, enquanto que o ponto 1 é o menos $\left(H^{\prime}=1,04\right)$. A distribuição mais homogênea dos indivíduos entre as diferentes espécies ocorre na estação $6\left(E_{H}=0,79\right)$ e a menor na estação $1\left(E_{H}=0,50\right)$.

A análise morfométrica revela o predomínio de carapaças médias $(125-250 \mu \mathrm{m})$ na região, com valores que variam entre 60\% (\#6) e 83\% (\#1) (Fig. 25). Carapaças pequenas (< $125 \mu \mathrm{m})$ estão presentes em todos os pontos do estudo, tendo sua menor porcentagem na

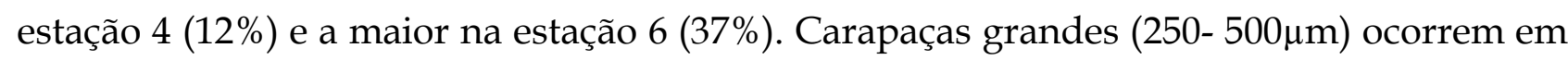
pequenas porcentagens ( 1 a $6 \%$ ) e estão ausentes nas estações 5 e 10. Testas muito grandes

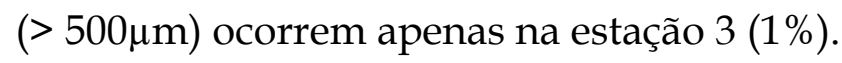

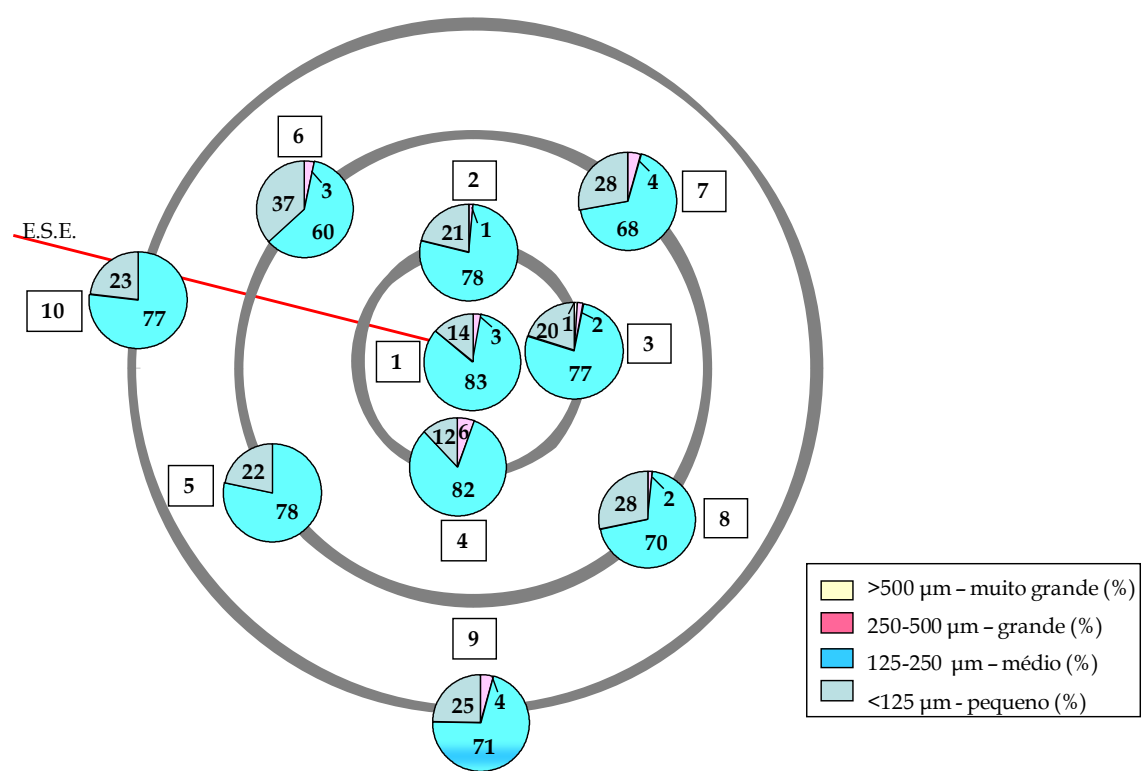

Figura 25: Morfometria das carapaças da biocenose de 2006. E.S.E.= emissário submarino de esgoto das Cigarras. 
A partir da análise morfológica, observa-se que as testas inteiras predominam em metade das amostras, com valores que oscilam entre $42 \%$ (\#5) a $57 \%$ (\#3) das carapaças totais (Fig. 26). As parcialmente fragmentadas dominam o restante das amostras, perfazendo de 40\% (\#3) a 55\% (\#4 e \#5). Fragmentos ocorrem em pequenos valores que variam de $2 \%$ (\#7, \#9 e \#10) a 4\% (\#6), e estão ausentes nos pontos 1 e 4.

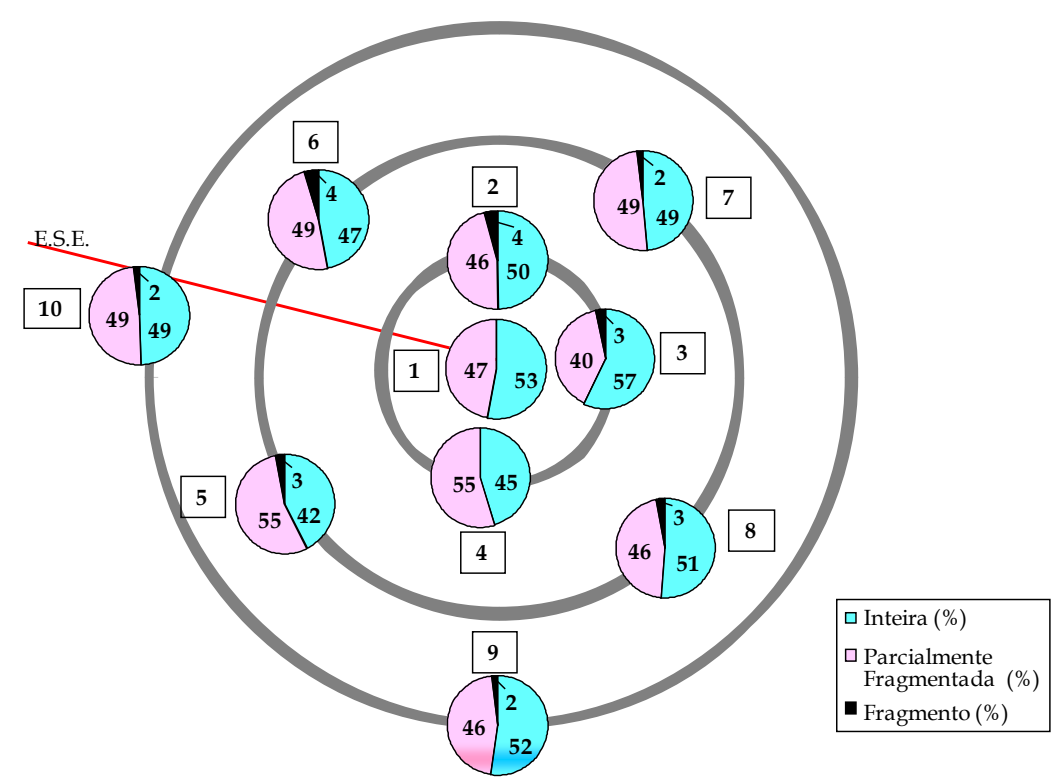

Figura 26: Análise morfológica das carapaças da biocenose de 2006. E.S.E.= emissário submarino de esgoto das Cigarras.

As espécies indicadoras de matéria orgânica (m.o.) e de ambiente rico em oxigênio estão representadas na tabela 05 . 
Tabela 05. Frequência relativas dos indicadores de matéria orgânica e oxigênio de 2006.

\begin{tabular}{|c|c|c|c|c|c|c|c|c|c|c|c|}
\hline & $\begin{array}{r}\text { Estação } \\
\text { V= vivo }\end{array}$ & $\begin{array}{c}\# 1 \\
\% \mathrm{~V} \\
\end{array}$ & $\begin{array}{l}\# 2 \\
\% \mathrm{~V}\end{array}$ & $\begin{array}{c}\# 3 \\
\% \mathrm{~V} \\
\end{array}$ & $\begin{array}{l}\# 4 \\
\% \mathrm{~V} \\
\end{array}$ & $\begin{array}{r}\# 5 \\
\% \mathrm{~V} \\
\end{array}$ & $\begin{array}{l}\# 6 \\
\% \mathrm{~V} \\
\end{array}$ & $\begin{array}{c}\# 7 \\
\% \mathrm{~V} \\
\end{array}$ & $\begin{array}{c}\# 8 \\
\% \mathrm{~V} \\
\end{array}$ & $\begin{array}{r}\# 9 \\
\% \mathrm{~V} \\
\end{array}$ & $\begin{array}{l}\# 10 \\
\% \mathrm{~V}\end{array}$ \\
\hline \multirow{14}{*}{ 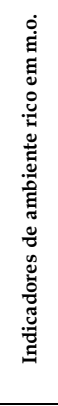 } & Ammotium salsum & 0,0 & 0,0 & 0,0 & 0,0 & 0,0 & 0,0 & 0,0 & 0,0 & 0,7 & 0,0 \\
\hline & Bolivina compacta & 0,9 & 1,5 & 0,0 & 0,0 & 0,0 & 0,0 & 1,0 & 1,2 & 0,7 & 0,0 \\
\hline & Bolivina danvillensis & 0,0 & 0,0 & 0,0 & 0,5 & 0,0 & 0,0 & 0,0 & 0,0 & 0,0 & 0,0 \\
\hline & Bolivina doniezi & 0,0 & 1,5 & 0,0 & 0,9 & 1,0 & 0,0 & 1,0 & 1,2 & 1,4 & 0,7 \\
\hline & Bolivina ordinaria & 1,8 & 2,3 & 0,0 & 2,3 & 0,0 & 0,0 & 1,0 & 0,0 & 2,1 & 0,0 \\
\hline & Bolivina sp. & 0,9 & 0,8 & 5,1 & 0,0 & 0,0 & 0,9 & 1,0 & 0,0 & 0,7 & 0,0 \\
\hline & Bulimina marginata & 0,0 & 0,0 & 0,0 & 0,0 & 0,0 & 0,0 & 2,0 & 0,0 & 0,0 & 0,7 \\
\hline & Buliminella elegantissima & 1,8 & 1,5 & 4,1 & 3,3 & 0,0 & 0,9 & 1,0 & 2,4 & 1,4 & 4,6 \\
\hline & Brizalina striatula & 2,7 & 0,8 & 9,2 & 5,1 & 1,0 & 1,8 & 5,1 & 4,9 & 2,7 & 0,7 \\
\hline & Cassidulina crassa & 0,0 & 0,0 & 0,0 & 0,9 & 0,0 & 0,0 & 1,0 & 0,0 & 0,7 & 0,0 \\
\hline & Hopkinsina pacifica & 0,0 & 0,0 & 0,0 & 0,0 & 0,0 & 0,0 & 0,0 & 0,6 & 0,0 & 0,0 \\
\hline & Pseudononion atlanticum & 0,0 & 0,0 & 1,0 & 0,9 & 1,0 & 0,0 & 1,0 & 0,6 & 0,7 & 0,7 \\
\hline & Pseudononion sp. & 0,0 & 0,0 & 1,0 & 0,0 & 0,0 & 0,0 & 0,0 & 0,0 & 0,7 & 0,0 \\
\hline & Total & 8,2 & 8,4 & 20,4 & 14,0 & 2,9 & 3,5 & 14,3 & 11,0 & 11,6 & 7,2 \\
\hline \multirow{3}{*}{ 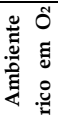 } & & & & & & & & & & & \\
\hline & Neocornobina terquemi & 0,0 & 0,0 & 0,0 & 0,0 & 0,0 & 0,0 & 0,0 & 0,0 & 1,4 & 0,0 \\
\hline & Total & 0,0 & 0,0 & 0,0 & 0,0 & 0,0 & 0,0 & 0,0 & 0,0 & 1,4 & 0,0 \\
\hline
\end{tabular}

Indicadores de matéria orgânica estão representados por 8 gêneros e 11 espécies, sendo sua ocorrência majoritariamente rara, seguida por acessória (Fig. 27). A B. striatula é a espécie de maior frequência, predominando nos pontos 3, 4, 6, 7 e 8. O grupo das bolivinas, constituído por B. compacta, B. danvillensis, B. doniezi, B. ordinaria e B. sp., está presente em todos os pontos amostrais, sendo dominante nas estações 1, 2 e 9. Já na estação 10, a principal espécie é a B. elegantissima. Em menor frequência ocorrem os Pseudononion spp., seguidos pela B. marginata, C. crassa, A. salsum e H. pacifica. A espécie $N$. terquemi é a única indicadora de ambiente rico em oxigênio, sendo sua ocorrência rara e restrita à estação 9 (Fig. 27 E). 


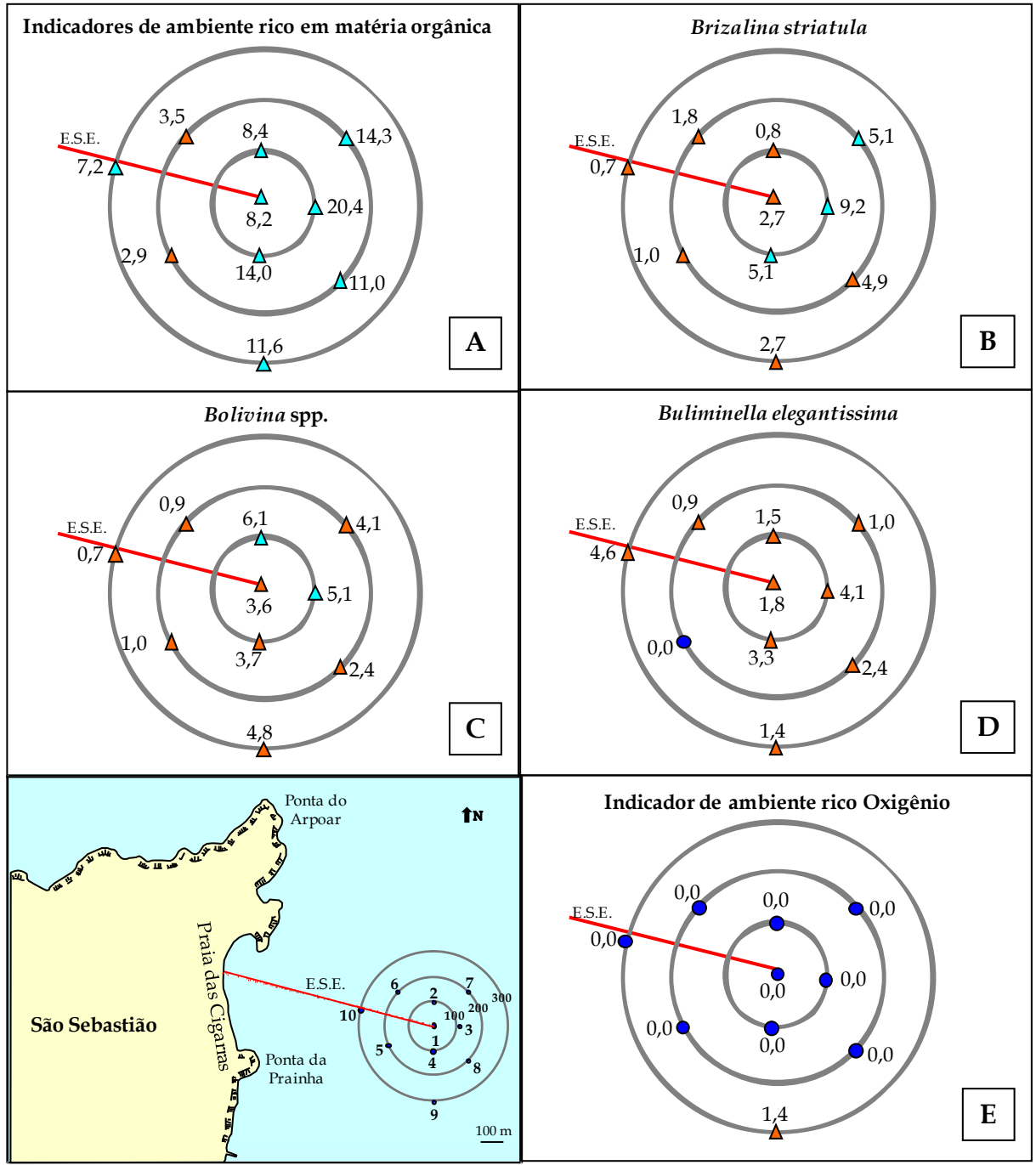

- > $49 \%$ - dominante $049-25 \%$-subdominante $\Delta 24-5 \%$ - acessória $\Delta<5 \%$-rara

Figura 27: A: Frequência relativa total dos indicadores de ambientes rico em matéria orgânica (m.o.). B, C e D: principais indicadores de m.o. E: indicador de ambiente rico em oxigênio de 2006. E.S.E.= emissário submarino de esgoto das Cigarras.

A análise de agrupamento numérica (modo Q) revela a formação de um único grupo caracterizado por 3 subgrupos (Fig. 28). O primeiro subgrupo é constituído pelas estações 1, 3, 6, 7 e 9. O segundo subgrupo é formado pelos pontos amostrais 4 e 8 , e o terceiro pelas estações 2, 5 e 10. Verifica-se similaridade entre os primeiros subgrupos e forte dissimilaridade deles em relação ao terceiro. 


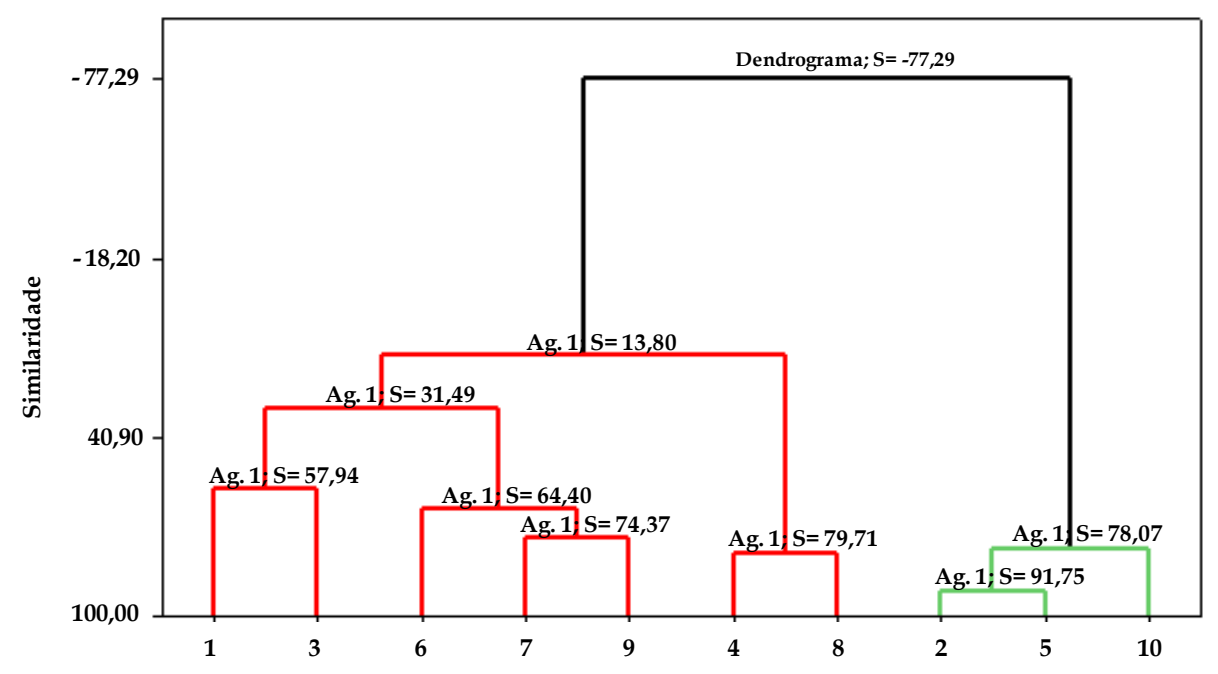

Figura 28: Análise de agrupamento numérica (modo Q) de 2006. Ag.= agrupamento.

A análise inversa (modo R) agrupou as principais espécies em uma mesma associação, apresentando similaridade de 48,65\% (Fig. 29). Há maior similaridade entre as espécies A. tepida e B. striatula $(67,69 \%)$ do que entre a A. parkinsoniana. Assim, os representantes da biocenose são compostos por espécie indicadora de ambiente rico em matéria orgânica e eurihalinos oportunistas.

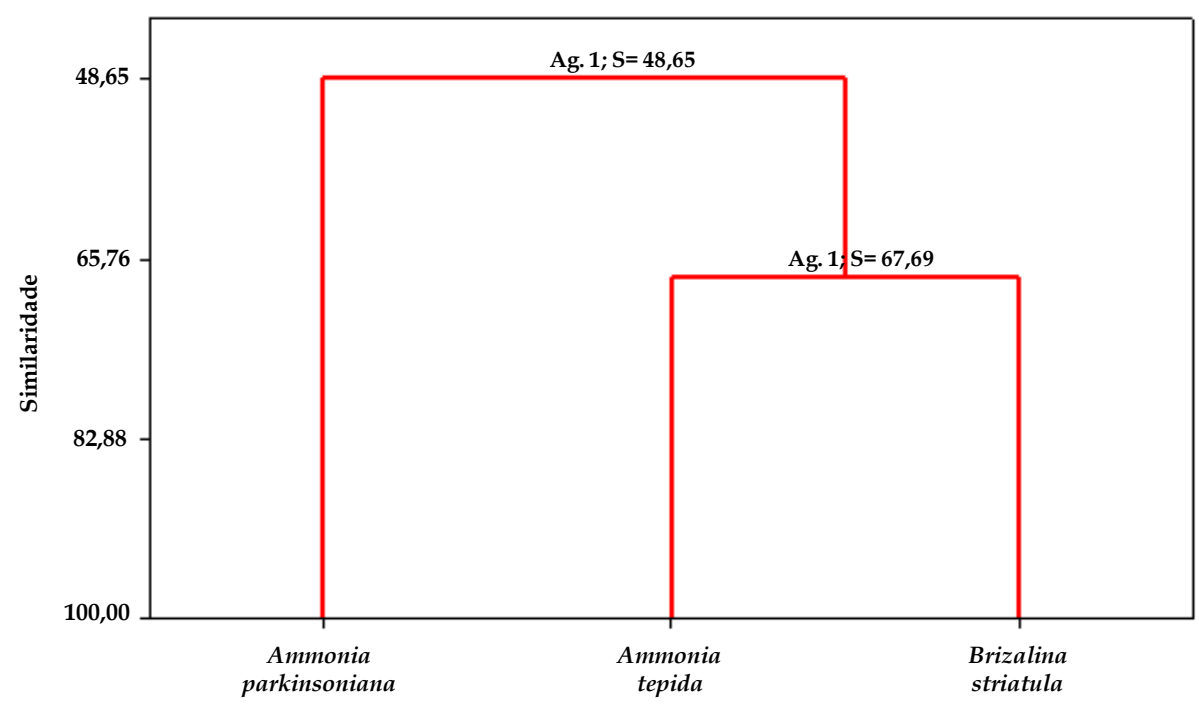

Figura 29: Análise de agrupamento inversa (modo R) de 2006. Ag.= agrupamento. 


\subsection{4.c Comparação da biocenose com a tanatocenose de 2006}

Constata-se que a tanatocenose é mais rica e mais densa que a biocenose. Em ambas há predomínio de rotalíneos de carapaças médias e do gênero Ammonia. Indivíduos de $P$. cananeiaensis são bastante abundantes na tanatocenose, porém são quase inexistentes na biocenose. De acordo com os resultados obtidos pelo Teste de Kruskal Wallis, constata-se a existência de uma diferença extremamente significativa entre as associações de mortos e vivos $(\mathrm{p}<0,01)($ Fig. 30).

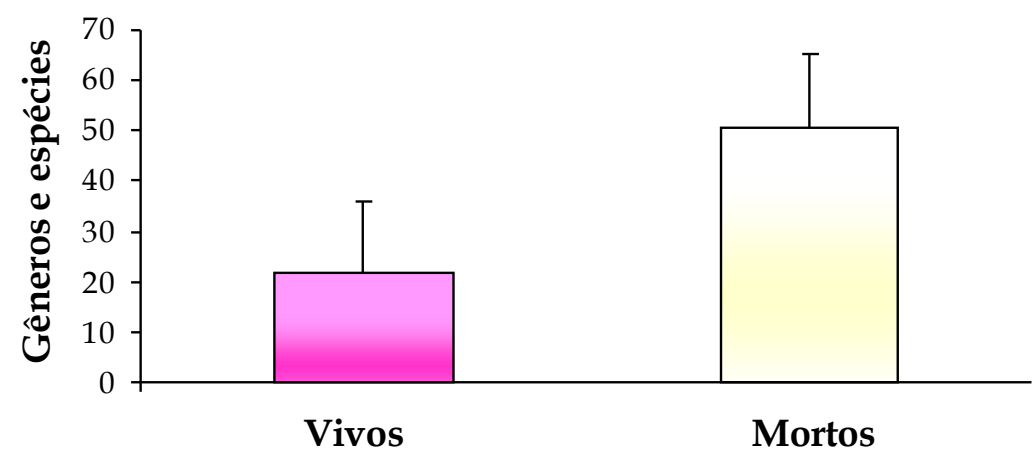

Figura 30: Relação entre a média do número de gêneros e espécies, e seu respectivo desviopadrão, da tanatocenose e da biocenose de 2006.

\subsection{Setembro de 2007}

\subsubsection{Parâmetros hidrográficos e hidroquímicos}

Os dados físico-químicos da coluna d'água encontram-se no Anexo 03.

A coluna d'água não apresenta estratificação vertical nem horizontal quanto à salinidade, temperatura e o $\mathrm{pH}$. A temperatura e o $\mathrm{pH}$ possuem tendência de decréscimo dos seus valores da superfície em direção ao fundo, enquanto que com a salinidade ocorre o inverso. Todos os valores obtidos encontram-se acima do limite mínimo determinado pelo CONAMA.

A turbidez é crescente da superfície em direção ao fundo em quase todas as estações, com exceção dos pontos 2 e 10, onde há diminuição da turbidez no meio da coluna d'água, com posterior elevação ao fundo. Os valores oscilam entre 1,2 e 7,6 UNT na 
superfície, 2,1 e 6,6 UNT no meio e 7,8 e 25 UNT no fundo. Todos os pontos possuem maiores valores de turbidez no fundo. O disco de secchi apresenta profundidade mínima de $0,8 \mathrm{~m}$, na estação 10, e profundidade máxima de $2,8 \mathrm{~m}$, na estação 7 .

As estações apresentam teores de OD dentro do estipulado pela legislação (>6 mg. $\mathrm{L}^{-1}$ ), sendo os valores encontrados superiores a 7,28 mg.L-1. Com exceção dos pontos 4 e 10, as estações apresentam menores teores no fundo.

\subsubsection{Parâmetros Granulométricos}

Os dados granulométricos da área de estudo de Setembro de 2007 estão representados na tabela 06.

Tabela 06. Análises granulométricas de Setembro de 2007. MPS= muito pobremente selecionado.

\begin{tabular}{|c|c|c|c|c|c|c|c|c|c|c|c|c|c|c|c|c|}
\hline \multirow{3}{*}{ Estação } & \multirow{3}{*}{$\begin{array}{l}\text { D. Médio } \\
\text { (Ф) }\end{array}$} & \multirow{3}{*}{$\begin{array}{c}\text { Grau } \\
\text { de seleção o }\end{array}$} & \multirow{3}{*}{$\begin{array}{c}\text { Classificação } \\
\text { Folk \& Ward (1957) }\end{array}$} & \multirow{3}{*}{$\begin{array}{r}\text { Classificação } \\
\text { Shepard (1954) }\end{array}$} & \multicolumn{12}{|c|}{ GRANULOMETR I A (\%) } \\
\hline & & & & & & Cascalho & & & & Are & & & & & Lama & \\
\hline & & & & & Seixos & Grânulos & Total & $\begin{array}{l}\text { Muito } \\
\text { grossa }\end{array}$ & Grossa & Média & Fina & $\begin{array}{c}\text { Muito } \\
\text { fina }\end{array}$ & Total & Silte & Argila & Total \\
\hline 1 & 3,73 & 2,87 & MPS & Areia síltica & 0,00 & 1,84 & 1,84 & 3,03 & 15,92 & 13,77 & 18,99 & 7,91 & 59,62 & 27,41 & 11,13 & 38,54 \\
\hline 2 & 4,20 & 2,53 & MPS & Areia síltica & 0,00 & 0,74 & 0,74 & 4,21 & 9,59 & 13,62 & 17,22 & 9,93 & 54,58 & 29,01 & 15,67 & 44,69 \\
\hline 3 & 4,07 & 2,79 & MPS & Areia síltica & 0,00 & 0,60 & 0,60 & 1,69 & 13,82 & 14,22 & 15,77 & 8,13 & 53,64 & 35,11 & 10,65 & 45,76 \\
\hline 4 & 3,61 & 2,86 & MPS & Areia síltica & 0,00 & 0,64 & 0,64 & 4,35 & 13,30 & 17,93 & 21,43 & 8,18 & 65,20 & 21,54 & $=12,62$ & 34,17 \\
\hline 5 & 4,08 & 2,33 & MPS & Silte arenoso & 0,00 & 1,20 & 1,20 & 3,36 & 7,96 & 11,83 & 16,17 & 6,05 & 45,37 & 45,92 & 7,52 & 53,43 \\
\hline 6 & 4,12 & 2,53 & MPS & Silte arenoso & 0,00 & 1,67 & 1,67 & 3,57 & 7,16 & 10,85 & 11,22 & 5,26 & 38,06 & 56,06 & 4,21 & 60,28 \\
\hline 7 & 3,57 & 2,60 & MPS & Areia síltica & 0,00 & 0,75 & 0,75 & 3,26 & 10,18 & 14,51 & 19,24 & 12,97 & 60,16 & 33,02 & 6,07 & 39,09 \\
\hline 8 & 4,18 & 2,44 & MPS & Silte arenoso & 0,00 & 0,52 & 0,52 & 0,88 & 6,36 & 10,84 & 16,61 & 10,95 & 45,65 & 46,72 & 7,11 & 53,83 \\
\hline 9 & 4,12 & 2,52 & MPS & Areia síltica & 0,00 & 0,43 & 0,43 & 0,93 & 11,62 & 17,10 & 20,30 & 8,15 & 58,10 & 25,87 & 15,61 & 41,47 \\
\hline 10 & 6,33 & 2,29 & MPS & Silte argiloso & 0,00 & 0,33 & 0,33 & 0,38 & 1,19 & 3,74 & 5,79 & 3,44 & 14,53 & 56,39 & 28,75 & 85,14 \\
\hline Máximo & 6,33 & 2,87 & & & 0,00 & 1,84 & 1,84 & 4,35 & 15,92 & 17,93 & 21,43 & 12,97 & 65,20 & 56,39 & 28,75 & 85,14 \\
\hline Mínimo & 3,57 & 2,29 & & & 0,00 & 0,33 & 0,33 & 0,38 & 1,19 & 3,74 & 5,79 & 3,44 & 14,53 & 21,54 & 4,21 & 34,17 \\
\hline Média & 4,33 & 2,58 & & & 0,00 & 0,87 & 0,87 & 2,57 & 9,71 & 12,84 & 16,28 & 8,10 & 49,49 & 37,70 & 11,94 & 49,64 \\
\hline Desvio-padrão & 0,78 & 0,20 & & & 0,00 & 0,49 & 0,49 & 1,39 & 4,07 & 3,77 & 4,42 & 2,63 & 14,02 & 12,03 & 6,71 & 14,09 \\
\hline
\end{tabular}

De acordo com Shepard (1954), os sedimentos da área de estudo são classificados, em ordem decrescente de abundância, como areia síltica, silte arenoso e silte argiloso, sendo muito pobremente selecionados (Folk e Ward, 1957) (Fig. 31 A). As estações 1, 2, 3, 4, 7 e 9 apresentam maiores porcentagens de areia síltica. Já os pontos 5, 6 e 8 possuem maior contribuição de silte arenoso, enquanto que o 10 é o único ponto classificado como silte argiloso. 
A estação 4 apresenta as maiores porcentagens de areia (65\%), enquanto que a 10 as menores (15\%) (Fig. 31 B). As quantidades mais representativas de areia estão localizadas na saída do emissário (\# 1), a 100 m (\# 2, 3 e 4), a 200 m à nordeste (\# 7) e a 300 m ao sul (\# 9). Sedimentos lamosos ocorrem em porcentagens que variam entre 34\% (\#4) e 85\% (\#10), predominando à oeste da malha amostral (\# 5, 6 e 10). Grânulos são encontrados em pequenas porcentagens (1-2\%), e estão ausentes apenas nas estações 8 e 10. As frações granulométricas predominantes são areia fina e silte.

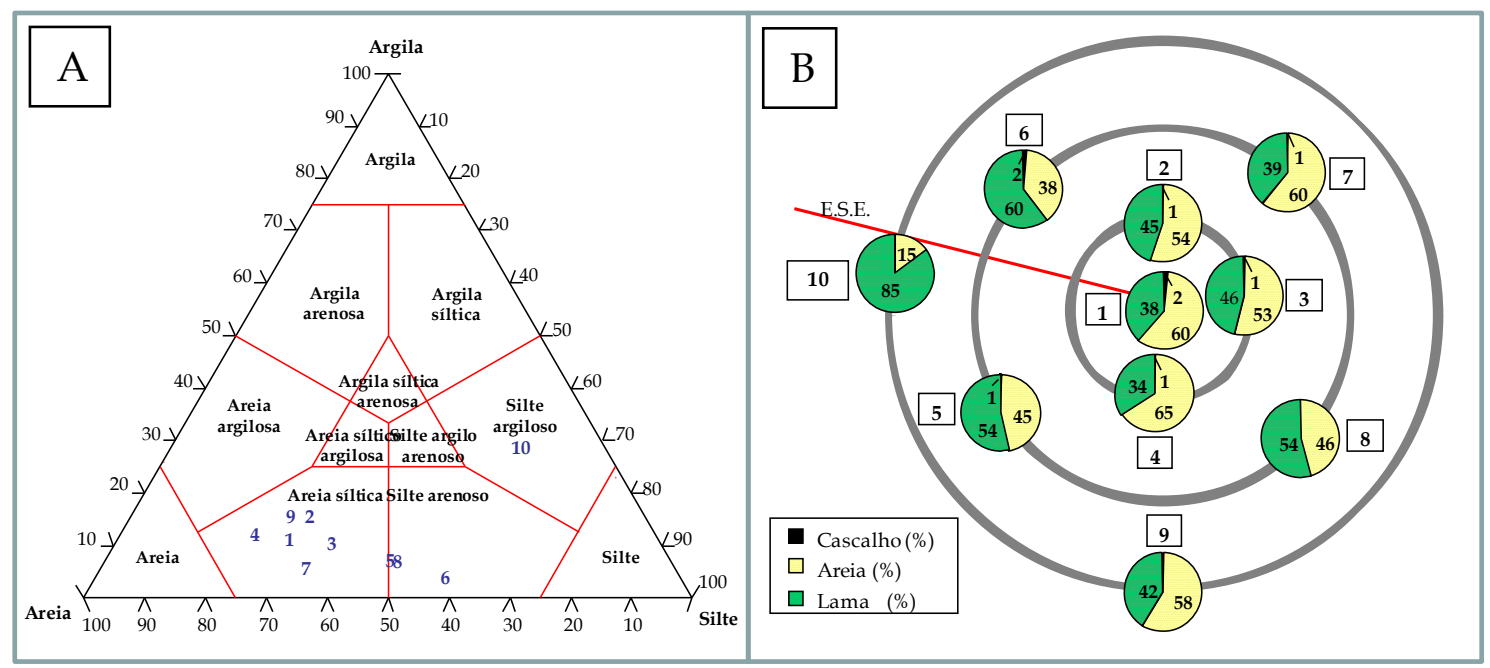

Figura 31: Classificação granulométrica por Shepard (1954). B: Granulometria dos sedimentos de 2007. E.S.E.= emissário submarino de esgoto.

\subsubsection{Parâmetros Geoquímicos}

Os dados geoquímicos dos nutrientes estão dispostos na tabela 07. 
Tabela 07. Dados geoquímicos dos nutrientes dos sedimentos de 2007.

\begin{tabular}{|cccccccc|}
\hline Estação & $\begin{array}{c}\text { CaCO3 } \\
(\mathbf{\%})\end{array}$ & $\begin{array}{c}\text { Classificação dos sedimentos } \\
\text { (Larsonneur, 1977) }\end{array}$ & $\begin{array}{c}\mathbf{S} \\
\mathbf{( \% )}\end{array}$ & $\begin{array}{c}\text { C org } \\
\mathbf{( \% )}\end{array}$ & $\mathbf{C / S}$ & $\begin{array}{c}\mathbf{N} \\
\mathbf{( \% )}\end{array}$ & $\mathbf{C / N}$ \\
\hline 1 & 12,29 & Litoclástico & 0,26 & 0,76 & 2,98 & 0,20 & 3,80 \\
2 & 13,32 & Litoclástico & 0,27 & 1,27 & 4,76 & 0,27 & 4,70 \\
3 & 12,61 & Litoclástico & 0,28 & 1,09 & 3,92 & 0,22 & 4,95 \\
4 & 11,46 & Litoclástico & 0,19 & 0,83 & 4,37 & 0,24 & 3,46 \\
5 & 14,98 & Litoclástico & 0,32 & 1,29 & 4,03 & 0,25 & 5,16 \\
6 & 16,49 & Litoclástico & 0,43 & 2,74 & 6,45 & 0,40 & 6,85 \\
7 & 11,76 & Litoclástico & 0,22 & 2,68 & 12,29 & 0,33 & 8,12 \\
8 & 14,6 & Litoclástico & 0,31 & 1,44 & 4,69 & 0,56 & 2,57 \\
9 & 12,37 & Litoclástico & 0,28 & 2,75 & 9,82 & 0,30 & 9,17 \\
10 & 24,03 & Litoclástico & 0,56 & 2,56 & 4,56 & 0,40 & 6,40 \\
\hline
\end{tabular}

Todas as estações apresentam sedimentos litoclásticos (Larssoneur, 1977), ou seja, seus teores de carbonato de cálcio são inferiores a 30\%, sendo o menor valor encontrado na estação $4(11,46 \%)$ e o maior na estação 10 (24,03 \%).

Os teores de carbono orgânico oscilam entre 0,76 \% (\# 1) e 2, 75\% (\#9). As maiores porcentagens encontram-se nos pontos amostrais mais afastados da saída dos difusores (Fig. 32).

Assim como em 2006, as menores concentrações de enxofre total ocorrem na desembocadura do emissário e nas estações que distam 100 m da mesma, enquanto que estações mais afastadas possuem os maiores valores. A menor porcentagem de enxofre ocorre no ponto amostral 4 (0,19\%) e a maior no ponto 10 (0,56 \%) (Fig. 32).

Em relação ao nitrogênio total, o menor valor obtido localiza-se na saída dos difusores (\# 1), com 0,20\%. Já o maior valor é encontrado à sudeste (\# 6) com 0,56\% (Fig. 32). Os menores teores ocorrem na saída do difusor, a $100 \mathrm{~m}$ do mesmo e a $200 \mathrm{~m}$ ao sudoeste.

A partir da razão C/S, verifica-se que a menor razão obtida ocorre no ponto $1(2,98)$ e a maior no ponto 7 (12,29) (Fig. 32). Na maioria das estações ocorrem deposições durante períodos de anoxia, porém nos pontos 6, 7 e 9, tanto a coluna d'água como os sedimentos encontram-se em condições óxicas.

Os valores da razão $\mathrm{C} / \mathrm{N}$ indicam predomínio de matéria orgânica marinha, seguida pela mista (Fig. 32). O menor valor ocorre no ponto $1(3,80)$ e o maior no ponto 9 
$(9,17)$. As estações localizadas no centro da malha amostral apresentam origem marinha, enquanto que os pontos com origem mista encontram-se a 200 e $300 \mathrm{~m}$ da saída dos difusores.

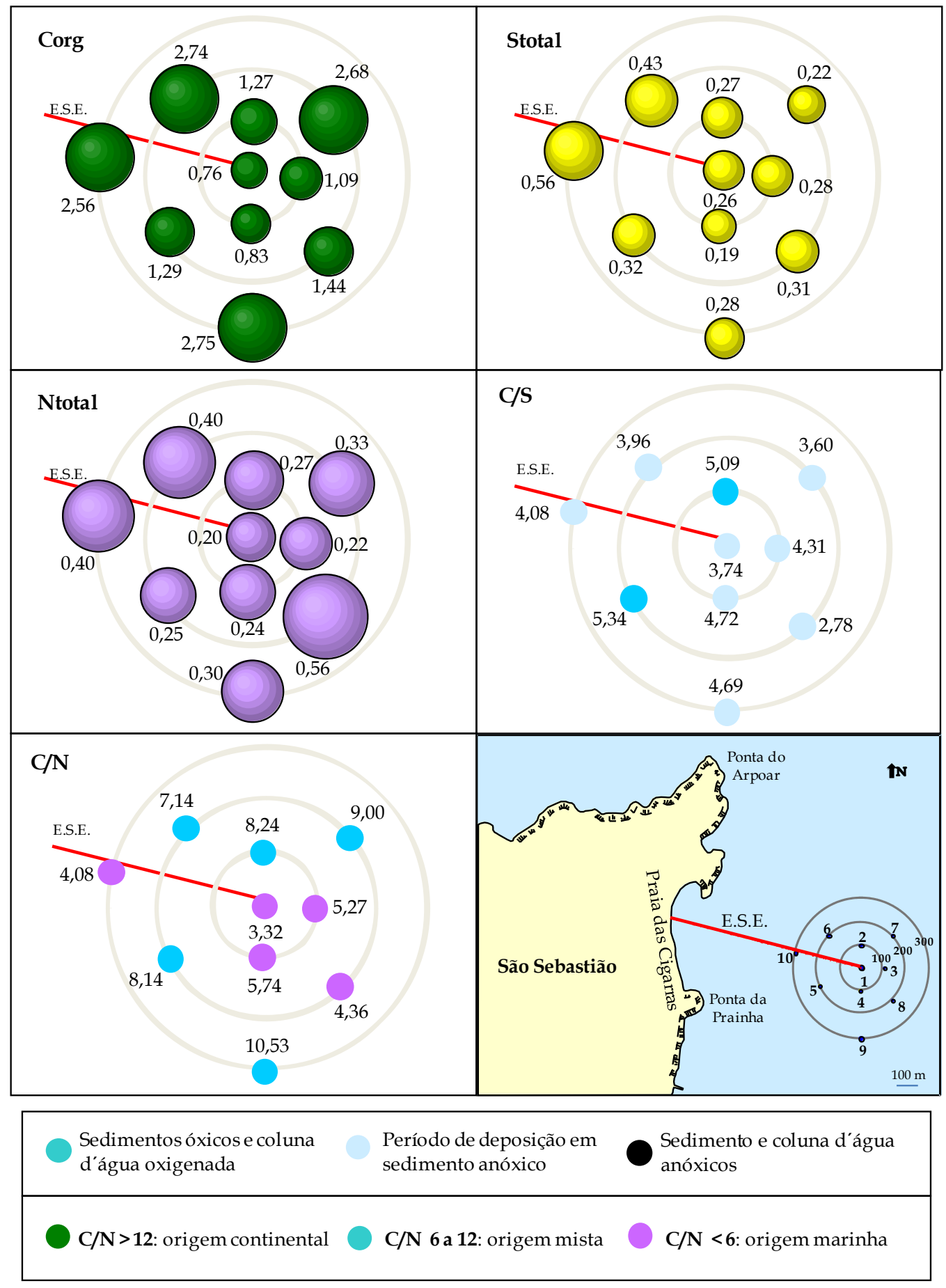

Figura 32: Porcentagens de carbono orgânico, enxofre total, nitrogênio total, razão C/S e C/N dos sedimentos de 2007. E.S.E.= emissário submarino de esgoto das Cigarras. 
Os resultados das análises do teor de HPAs dos sedimentos de 2007 estão dispostos na tabela 08 .

Tabela 08. Concentrações dos HPAs $(\mu \mathrm{g} / \mathrm{Kg})$ e taxas de recuperação dos surrogates utilizados nas análises de HPAs nos sedimentos de 2007. $\mathrm{LQ}=$ limite de quantificação em $\mu \mathrm{g} / \mathrm{Kg}$. Em negrito são os valores acima do limite de quantificação. A estação 9 não foi analisada, sendo representada por *.

\begin{tabular}{|c|c|c|c|c|c|c|c|c|c|c|c|}
\hline Compostos & $\# 1$ & $\# 2$ & \# 3 & $\# 4$ & \# 5 & $\# 6$ & $\# 7$ & $\# 8$ & \# 9 & \# 10 & LQ \\
\hline Acenafteno & $<5,0$ & $<5,0$ & $<5,0$ & $<5,0$ & $<5,0$ & $<5,0$ & $<5,0$ & $<5,0$ & * & $<5,0$ & 5,0 \\
\hline Acenaftileno & $<5,0$ & $<5,0$ & $<5,0$ & $<5,0$ & $<5,0$ & $<5,0$ & $<5,0$ & $<5,0$ & * & $<5,0$ & 5,0 \\
\hline Antraceno & $<5,0$ & $<5,0$ & $<5,0$ & $<5,0$ & $<5,0$ & $<5,0$ & $<5,0$ & $<5,0$ & * & $<5,0$ & 5,0 \\
\hline Benzo(a)antraceno & $<5,0$ & $<5,0$ & $<5,0$ & $<5,0$ & $<5,0$ & $<5,0$ & $<5,0$ & $<5,0$ & * & $<5,0$ & 5,0 \\
\hline Benzo(a)pireno & $<5,0$ & $<5,0$ & $<5,0$ & $<5,0$ & $<5,0$ & $<5,0$ & $<5,0$ & $<5,0$ & * & $<5,0$ & 5,0 \\
\hline Benzo(b)fluoranteno & $<5,0$ & $<5,0$ & $<5,0$ & $<5,0$ & $<5,0$ & $<5,0$ & $<5,0$ & $<5,0$ & * & $<5,0$ & 5,0 \\
\hline Benzo(k)fluoranteno & $<5,0$ & $<5,0$ & $<5,0$ & $<5,0$ & $<5,0$ & $<5,0$ & $<5,0$ & $<5,0$ & * & $<5,0$ & 5,0 \\
\hline Benzo[g, $\mathrm{h}$, i]perileno & $<5,0$ & $<5,0$ & $<5,0$ & $<5,0$ & $<5,0$ & $<5,0$ & $<5,0$ & $<5,0$ & * & $<5,0$ & 5,0 \\
\hline Criseno & $<5,0$ & $<5,0$ & $<5,0$ & $<5,0$ & $<5,0$ & $<5,0$ & $<5,0$ & $<5,0$ & * & $<5,0$ & 5,0 \\
\hline Dibenzo[a, h]antraceno & $<5,0$ & $<5,0$ & $<5,0$ & $<5,0$ & $<5,0$ & $<5,0$ & $<5,0$ & $<5,0$ & * & $<5,0$ & 5,0 \\
\hline Fenantreno & $<5,0$ & $<5,0$ & $<5,0$ & $<5,0$ & $<5,0$ & $<5,0$ & $<5,0$ & $<5,0$ & * & $<5,0$ & 5,0 \\
\hline Fluoranteno & $<5,0$ & $<5,0$ & $<5,0$ & $<5,0$ & $<5,0$ & $<5,0$ & $<5,0$ & $<5,0$ & * & $<5,0$ & 5,0 \\
\hline Fluoreno & $<5,0$ & $<5,0$ & $<5,0$ & $<5,0$ & $<5,0$ & $<5,0$ & $<5,0$ & $<5,0$ & * & $<5,0$ & 5,0 \\
\hline Indeno[1, 2,3-cd]pireno & $<5,0$ & $<5,0$ & $<5,0$ & $<5,0$ & $<5,0$ & $<5,0$ & $<5,0$ & $<5,0$ & * & $<5,0$ & 5,0 \\
\hline Naftaleno & $<5,0$ & $<5,0$ & $<5,0$ & 5,3 & $<5,0$ & 8,1 & $<5,0$ & $<5,0$ & * & $<5,0$ & 5,0 \\
\hline Pireno & $<5,0$ & $<5,0$ & $<5,0$ & $<5,0$ & $<5,0$ & $<5,0$ & $<5,0$ & $<5,0$ & * & $<5,0$ & 5,0 \\
\hline \multirow{2}{*}{ Surrogates } & \multicolumn{8}{|c|}{ Resultado de recuperação (\%) } & \multirow{2}{*}{\multicolumn{3}{|c|}{$\begin{array}{c}\text { Limite de controle } \\
\text { de qualidade }(\%)\end{array}$}} \\
\hline & \multicolumn{2}{|c|}{ Mínimo } & \multicolumn{2}{|c|}{ Máximo } & \multicolumn{2}{|c|}{ Média } & \multicolumn{2}{|c|}{ Desvio-padrão } & & & \\
\hline 2-Fluorobifenil & \multirow{2}{*}{\multicolumn{2}{|c|}{$\begin{array}{l}37 \\
45\end{array}$}} & \multicolumn{2}{|c|}{59} & \multicolumn{2}{|c|}{43,2} & \multicolumn{2}{|c|}{6,6} & \multicolumn{3}{|c|}{$24-111$} \\
\hline Terfenil-d14 & & & \multicolumn{2}{|c|}{77} & \multicolumn{2}{|c|}{55,9} & \multicolumn{2}{|c|}{9,5} & \multicolumn{3}{|c|}{$25-110$} \\
\hline
\end{tabular}

Os HPAs analisados encontram-se majoritariamente abaixo do limite de quantificação em todos os pontos amostrais. Apenas o Naftaleno é passível de quantificação nas estações $4(5,3 \mu \mathrm{g} / \mathrm{Kg})$ e $6(8,1 \mu \mathrm{g} / \mathrm{Kg})$.

As taxas de recuperação para ambos os surrogates encontram-se dentro dos limites de controle de qualidade.

\subsubsection{Análise dos Foraminíferos}

\subsection{4.a Tanatocenose}

As frequências relativas dos gêneros e espécies encontrados em setembro de 2007, assim como seus índices de diversidade de Shannon $\left(\mathrm{H}^{\prime}\right)$ e equitatividades $\left(\mathrm{E}_{\mathrm{H}^{\prime}}\right)$, estão apresentadas no Anexo 04. As fotomicrografias de alguns exemplares estão dispostas nas pranchas 1 e 2 no Anexo 08. 
Há ocorrência de 26 gêneros e 40 espécies de foraminíferos nas amostras, sendo todos bentônicos. As densidades variam entre 315 (\# 10) e 1472 indivíduos. 10 cc -1 (\# 2) (Fig. 33 A). O menor número de espécies encontradas ocorre nos pontos amostrais 4 e 10 (19 espécies), enquanto que a maior riqueza está presente no ponto 2 (27espécies) (Fig. 33 B).

As amostras possuem representantes das três principais subordens de foraminíferos, sendo que a Rotaliina constitui mais de 92\% dos indivíduos (Fig. 33 C). As subordens Miliolina e Textulariina ocorrem em pequenas porcentagens e somente em algumas estações (Fig. 33 D e E).

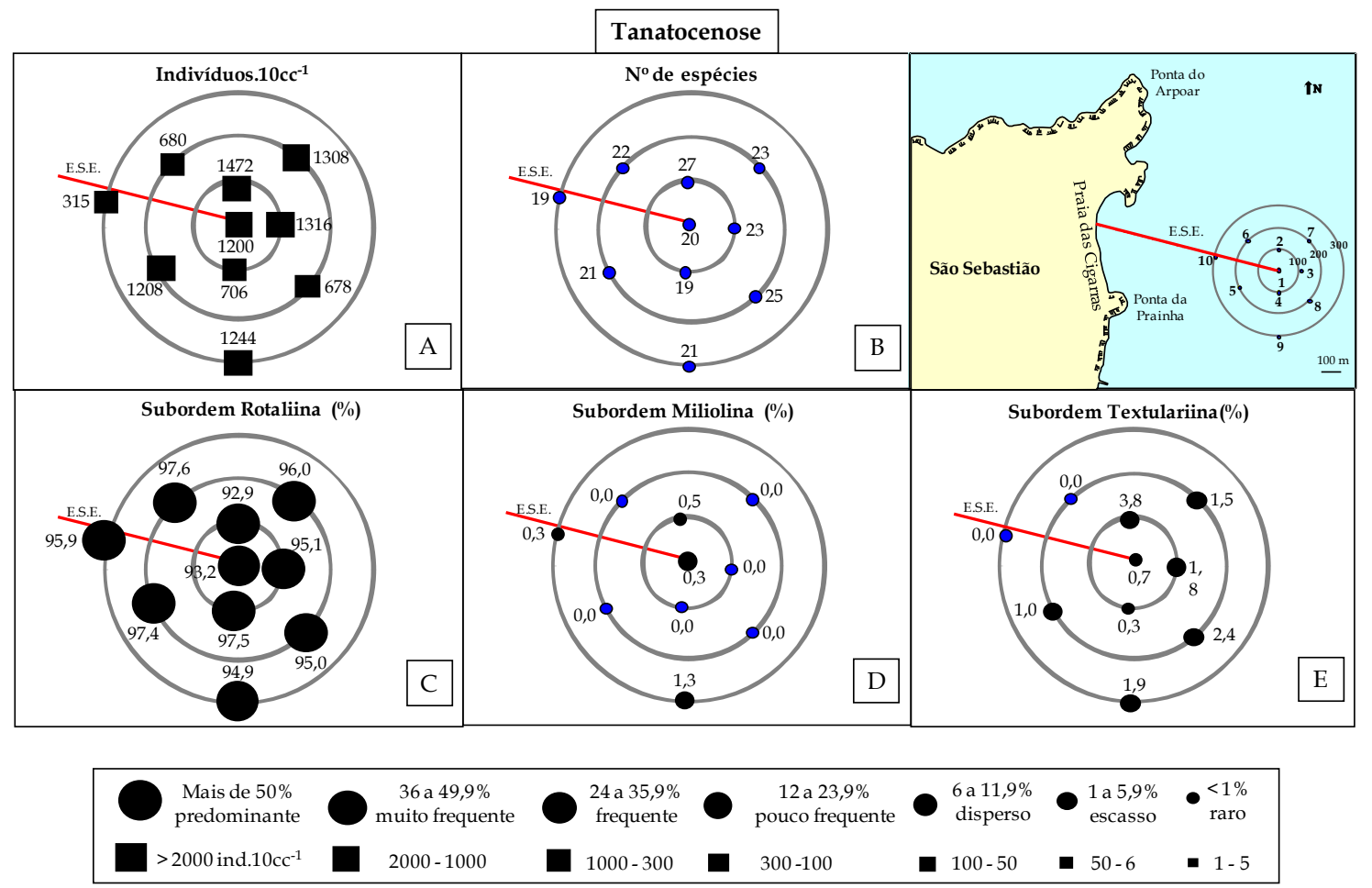

Figura 33: A: densidade, B: riqueza. Frequência relativa das principais subordens de foraminíferos (C, D e E) de 2007. E.S.E.= emissário submarino de esgoto das Cigarras.

O gênero predominante nas amostras é Ammonia, apresentando a menor porcentagem na estação 2 (35,3\%) e a maior na estação 10 (52,3\%). A A. tepida é a espécie mais representativa das amostras, correspondendo a até 34,8\% (\#4) dos foraminíferos. Em seguida, em ordem decrescente, está a $P$. cananeiaensis (até $24,1 \%$ - \# 10) e a $A$. 
parkinsoniana (20,5\% - \# 5). Os grupos dos cribroelfidiuns e das bolivinas ocorrem em todos os pontos amostrais, porém em menor quantidade.

Segundo o Índice de diversidade de Shannon, as estações 2 e 8 são as mais diversificadas $\left(H^{\prime}=2,60\right)$. O ponto 1 apresenta a maior homogeneidade na distribuição das espécies entre seus indivíduos $\left(E_{\mathrm{H}}=0,86\right)$. Já a estação 6 apresenta a maior heterogeneidade na distribuição das suas espécies $\left(\mathrm{E}_{\mathrm{H}}=0,68\right)$.

A análise morfométrica revela o predomínio de carapaças médias (125-250 $\mu \mathrm{m})$ na área de estudo, com porcentagens que variam entre 58\% (\#10) e 79\% (\#7) das amostras (Fig. 34). Carapaças pequenas (< $125 \mu \mathrm{m})$ e grandes $(250-500 \mu \mathrm{m})$ estão presentes em todos os pontos do estudo, com valores que oscilam entre $9 \%$ (\#7) e $41 \%$ (\#10), e entre $1 \%$ (\#10) e

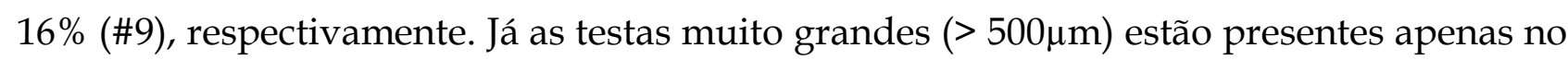
ponto amostral 2, correspondendo a apenas $1 \%$ da amostra.

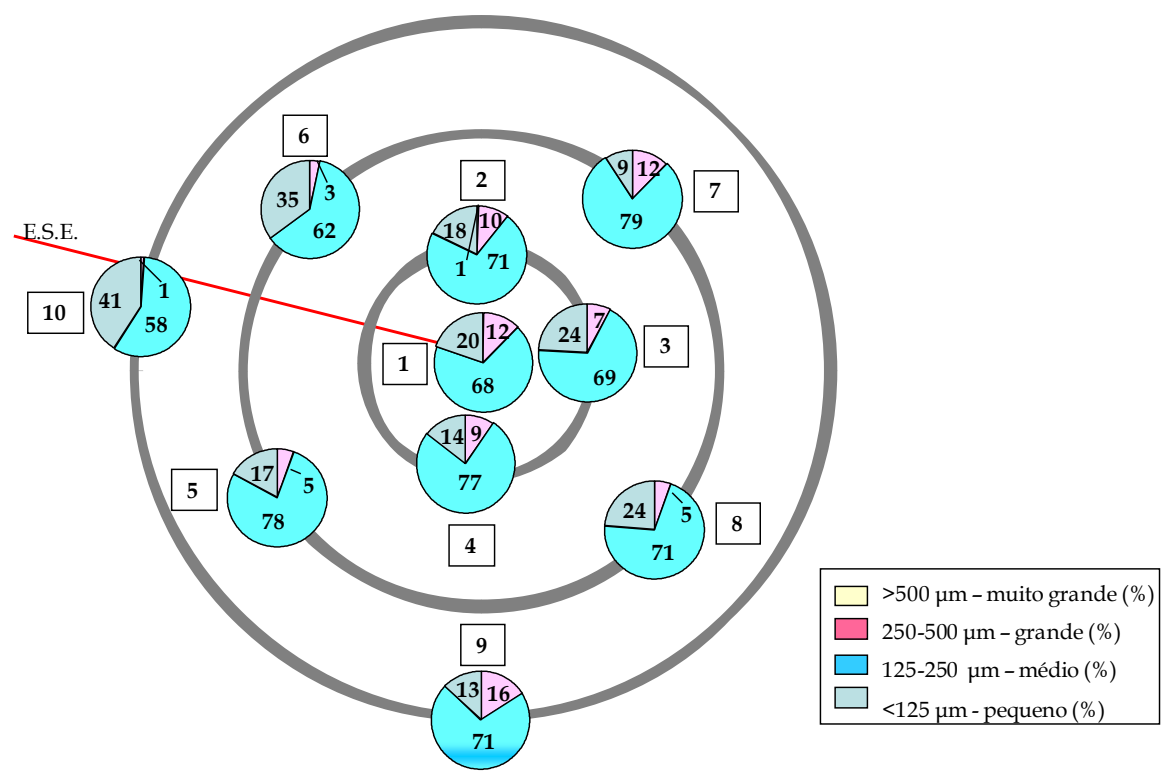

Figura 34: Morfometria das carapaças da tanatocenose de 2007. E.S.E.= emissário submarino de esgoto das Cigarras.

A análise tafonômica constata que as testas parcialmente fragmentadas são majoritárias, apresentando valores que oscilam entre 44\% (\# 5 e 7) e 55\% (\# 4) (Fig. 35). Com as testas inteiras ocorre exatamente o oposto. Fragmentos de foraminíferos estão presentes em todas as amostras, porém em pequenas porcentagens (1 a $2 \%$ ). 


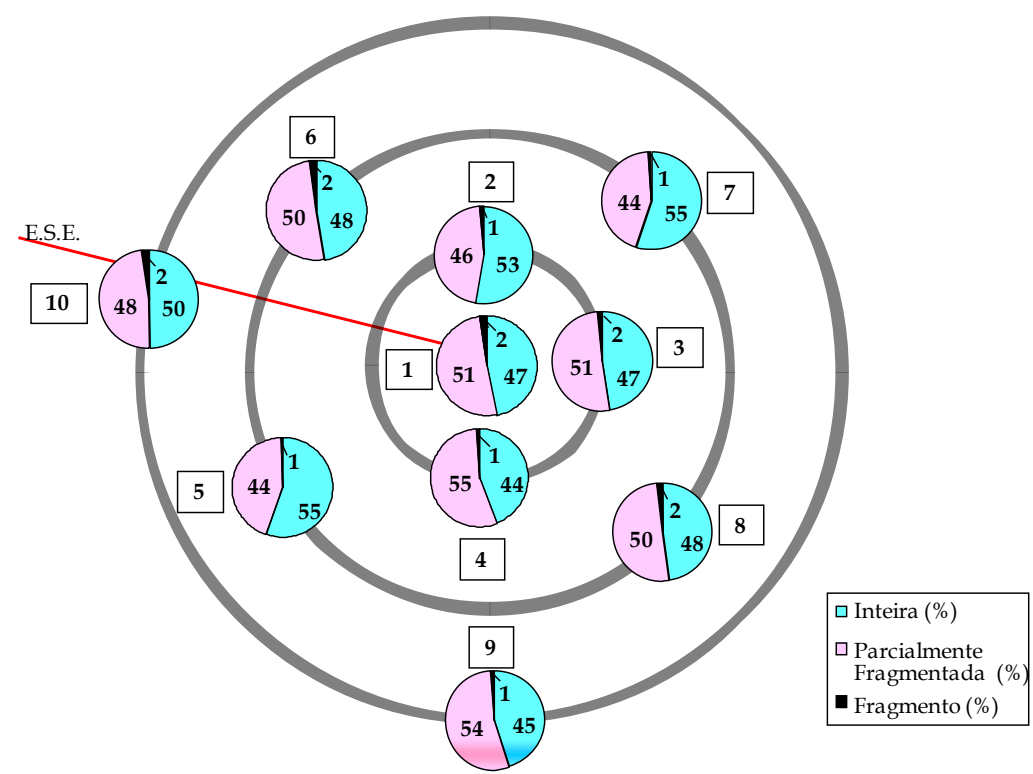

Figura 35: Análise tafonômica das carapaças da tanatocenose de 2007. E.S.E.= emissário submarino de esgoto das Cigarras.

As carapaças de coloração normal são majoritárias e ocorrem em todas as estações, perfazendo entre $93 \%$ (\#4 e 6) e 97\% (\#8 e 9) das amostras (Fig. 36). Carapaças limonitizadas, preenchidas de monossulfeto de ferro ou pirita estão presentes em todos os pontos amostrais, com porcentagens oscilando entre 1 e $3 \%$.

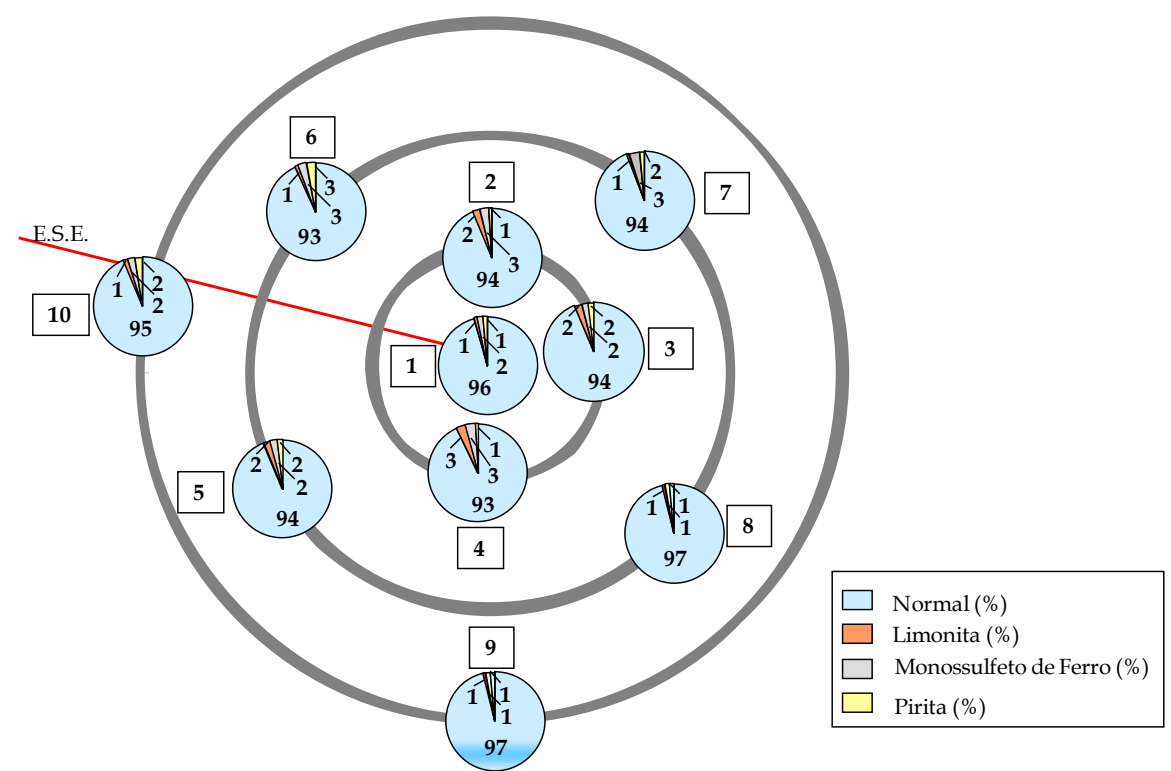

Figura 36: Coloração das carapaças da tanatocenose de 2007. E.S.E.= emissário submarino de esgoto das Cigarras. 
Os indicadores de ambiente rico em matéria orgânica e oxigênio estão listados na tabela 09 com suas respectivas frequências relativas.

Tabela 09. Frequência relativa dos gêneros e espécies indicadores de matéria orgânica e oxigênio de 2007.

\begin{tabular}{|c|c|c|c|c|c|c|c|c|c|c|c|}
\hline & $\begin{array}{c}\text { Estação } \\
M=\text { mortos }\end{array}$ & $\begin{array}{c}1 \\
\text { M \% }\end{array}$ & $\begin{array}{c}2 \\
M \%\end{array}$ & $\begin{array}{c}3 \\
M \%\end{array}$ & $\begin{array}{c}4 \\
M \%\end{array}$ & $\begin{array}{c}5 \\
M \%\end{array}$ & $\begin{array}{c}6 \\
M \%\end{array}$ & $\begin{array}{c}7 \\
\text { M } \%\end{array}$ & $\begin{array}{c}8 \\
\text { M \% }\end{array}$ & $\begin{array}{c}9 \\
\mathrm{M} \%\end{array}$ & $\begin{array}{c}10 \\
\text { M \% }\end{array}$ \\
\hline 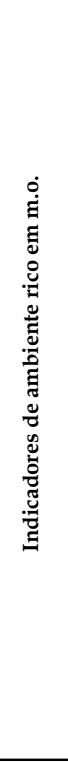 & $\begin{array}{l}\text { Ammoscalaria sp. } \\
\text { Ammotium salsum } \\
\text { Bolivina compacta } \\
\text { Bolivina danvillensis } \\
\text { Bolivina doniezi } \\
\text { Bolivina ordinaria } \\
\text { Bolivina pulchella } \\
\text { Bolivina sp. } \\
\text { Buccella peruviana } \\
\text { Bulimina marginata } \\
\text { Bulimina pupoides } \\
\text { Bulimina sp. } \\
\text { Buliminella elegantissima } \\
\text { Brizalina striatula } \\
\text { Cassidulina crassa } \\
\text { Cassidulina laevigata } \\
\text { Cassidulina minuta } \\
\text { Cassidulina subglobosa } \\
\text { Cassidulina sp. } \\
\text { Hopkinsina pacifica } \\
\text { Miliammina fusca } \\
\text { Pseudononion atlanticum } \\
\text { Pseudononion sp. } \\
\text { Uvigerina peregrina } \\
\text { Total } \\
\end{array}$ & $\begin{array}{c}0,0 \\
0,0 \\
0,0 \\
0,0 \\
3,4 \\
0,7 \\
2,7 \\
1,4 \\
0,7 \\
2,4 \\
0,0 \\
0,0 \\
3,4 \\
1,0 \\
1,7 \\
0,0 \\
0,0 \\
0,0 \\
0,0 \\
0,0 \\
0,0 \\
1,7 \\
0,0 \\
0,0 \\
19,0 \\
\end{array}$ & $\begin{array}{l}0,0 \\
0,8 \\
1,1 \\
0,0 \\
1,6 \\
0,0 \\
1,9 \\
1,1 \\
0,5 \\
1,4 \\
0,0 \\
0,3 \\
1,9 \\
1,1 \\
2,2 \\
0,0 \\
0,3 \\
0,3 \\
0,0 \\
0,0 \\
0,3 \\
2,4 \\
0,3 \\
0,0 \\
\mathbf{1 7 , 4} \\
\end{array}$ & $\begin{array}{l}0,0 \\
0,0 \\
0,6 \\
0,0 \\
0,9 \\
0,0 \\
3,6 \\
0,3 \\
0,3 \\
3,3 \\
0,6 \\
0,0 \\
1,2 \\
1,2 \\
0,6 \\
0,0 \\
0,3 \\
0,0 \\
0,0 \\
0,0 \\
0,0 \\
3,0 \\
0,9 \\
0,0 \\
\mathbf{1 7 , 0} \\
\end{array}$ & $\begin{array}{r}0,3 \\
0,0 \\
0,6 \\
0,6 \\
0,0 \\
0,0 \\
1,4 \\
0,3 \\
0,0 \\
2,8 \\
0,3 \\
0,0 \\
0,6 \\
1,4 \\
0,6 \\
0,0 \\
0,0 \\
0,0 \\
0,0 \\
0,0 \\
0,0 \\
3,4 \\
0,0 \\
0,0 \\
\mathbf{1 2 , 2} \\
\end{array}$ & $\begin{array}{c}0,0 \\
0,0 \\
0,3 \\
0,3 \\
1,0 \\
0,0 \\
3,0 \\
1,3 \\
0,0 \\
1,7 \\
0,3 \\
0,0 \\
2,0 \\
1,0 \\
0,7 \\
0,3 \\
0,0 \\
0,0 \\
0,0 \\
0,0 \\
0,0 \\
3,6 \\
0,0 \\
0,0 \\
15,6 \\
\end{array}$ & $\begin{array}{c}0,0 \\
0,0 \\
0,6 \\
0,0 \\
0,3 \\
0,9 \\
3,5 \\
0,3 \\
0,0 \\
2,6 \\
0,0 \\
0,0 \\
0,6 \\
1,2 \\
0,3 \\
0,0 \\
0,0 \\
0,0 \\
0,0 \\
0,0 \\
0,0 \\
0,3 \\
0,0 \\
0,0 \\
10,6 \\
\end{array}$ & $\begin{array}{c}0,3 \\
0,0 \\
0,0 \\
0,3 \\
0,6 \\
0,6 \\
4,9 \\
0,3 \\
0,0 \\
3,4 \\
0,3 \\
0,0 \\
1,5 \\
2,1 \\
0,9 \\
0,0 \\
0,0 \\
0,0 \\
0,6 \\
0,0 \\
0,3 \\
3,4 \\
0,0 \\
0,3 \\
19,9 \\
\end{array}$ & $\begin{array}{c}0,3 \\
0,0 \\
0,3 \\
0,6 \\
1,2 \\
1,5 \\
2,4 \\
1,2 \\
0,9 \\
2,7 \\
0,9 \\
0,3 \\
4,1 \\
2,4 \\
1,8 \\
0,6 \\
0,0 \\
0,0 \\
0,0 \\
0,3 \\
0,3 \\
1,8 \\
0,6 \\
0,0 \\
23,9 \\
\end{array}$ & $\begin{array}{c}0,0 \\
0,0 \\
0,6 \\
0,0 \\
0,3 \\
1,0 \\
1,6 \\
0,3 \\
0,0 \\
3,2 \\
0,6 \\
0,0 \\
0,0 \\
0,6 \\
0,0 \\
0,0 \\
0,6 \\
0,0 \\
0,3 \\
0,0 \\
0,3 \\
1,0 \\
0,0 \\
0,0 \\
10,6 \\
\end{array}$ & $\begin{array}{c}0,0 \\
0,0 \\
0,0 \\
0,3 \\
0,6 \\
1,9 \\
3,5 \\
1,0 \\
0,0 \\
0,3 \\
0,3 \\
0,0 \\
1,6 \\
1,6 \\
1,0 \\
0,0 \\
0,3 \\
0,0 \\
1,0 \\
0,0 \\
0,0 \\
2,5 \\
0,3 \\
0,0 \\
16,2 \\
\end{array}$ \\
\hline 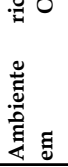 & $\begin{array}{l}\text { Discorbis bertheloli } \\
\text { Discorbis williamsoni } \\
\text { Hanzawaia bouena } \\
\text { Neocornobina terquemi } \\
\text { Total }\end{array}$ & $\begin{array}{l}0,0 \\
0,0 \\
0,3 \\
0,0 \\
\mathbf{0 , 3} \\
\end{array}$ & $\begin{array}{l}0,0 \\
0,0 \\
1,1 \\
0,0 \\
\mathbf{1 , 1}\end{array}$ & $\begin{array}{l}0,0 \\
0,0 \\
1,2 \\
0,3 \\
\mathbf{1 , 5}\end{array}$ & $\begin{array}{l}0,0 \\
0,0 \\
1,1 \\
0,0 \\
\mathbf{1 , 1} \\
\end{array}$ & $\begin{array}{l}0,0 \\
0,0 \\
0,3 \\
0,0 \\
\mathbf{0 , 3} \\
\end{array}$ & $\begin{array}{l}0,9 \\
0,0 \\
0,3 \\
0,3 \\
\mathbf{1 , 5}\end{array}$ & $\begin{array}{l}0,0 \\
0,0 \\
0,9 \\
0,0 \\
\mathbf{0 , 9}\end{array}$ & $\begin{array}{l}0,0 \\
0,0 \\
0,0 \\
0,0 \\
\mathbf{0 , 0}\end{array}$ & $\begin{array}{l}0,0 \\
0,0 \\
0,6 \\
0,0 \\
0,6\end{array}$ & $\begin{array}{l}0,0 \\
0,3 \\
0,0 \\
0,0 \\
\mathbf{0 , 3}\end{array}$ \\
\hline
\end{tabular}

Todas as estações da área de estudo apresentam indicadores de matéria orgânica de maneira acessória, sendo representados por 12 gêneros e 19 espécies de foraminíferos. Há 4 grupos mais abundantes: Bolivina spp., Bulimina spp., Pseudononion spp. e B. elegantissima (Fig. 37).

O grupo das bolivinas predomina em todas as estações, com exceção da 4, perfazendo até 52,8\% dos indicadores no ponto 6 . Na estação 9 há predomínio das buliminas, enquanto que no ponto 4 o grupo de Pseudononion spp. é dominante. Indivíduos de B. elegantissima perfazem no máximo 17,9\% dos indicadores. Em menores quantidades e em ordem decrescente há ocorrência de Cassidulina spp., B. striatula, B. peruviana, M. fusca, Ammoscalaria sp., A. salsum, H. pacifica e U. peregrina. 


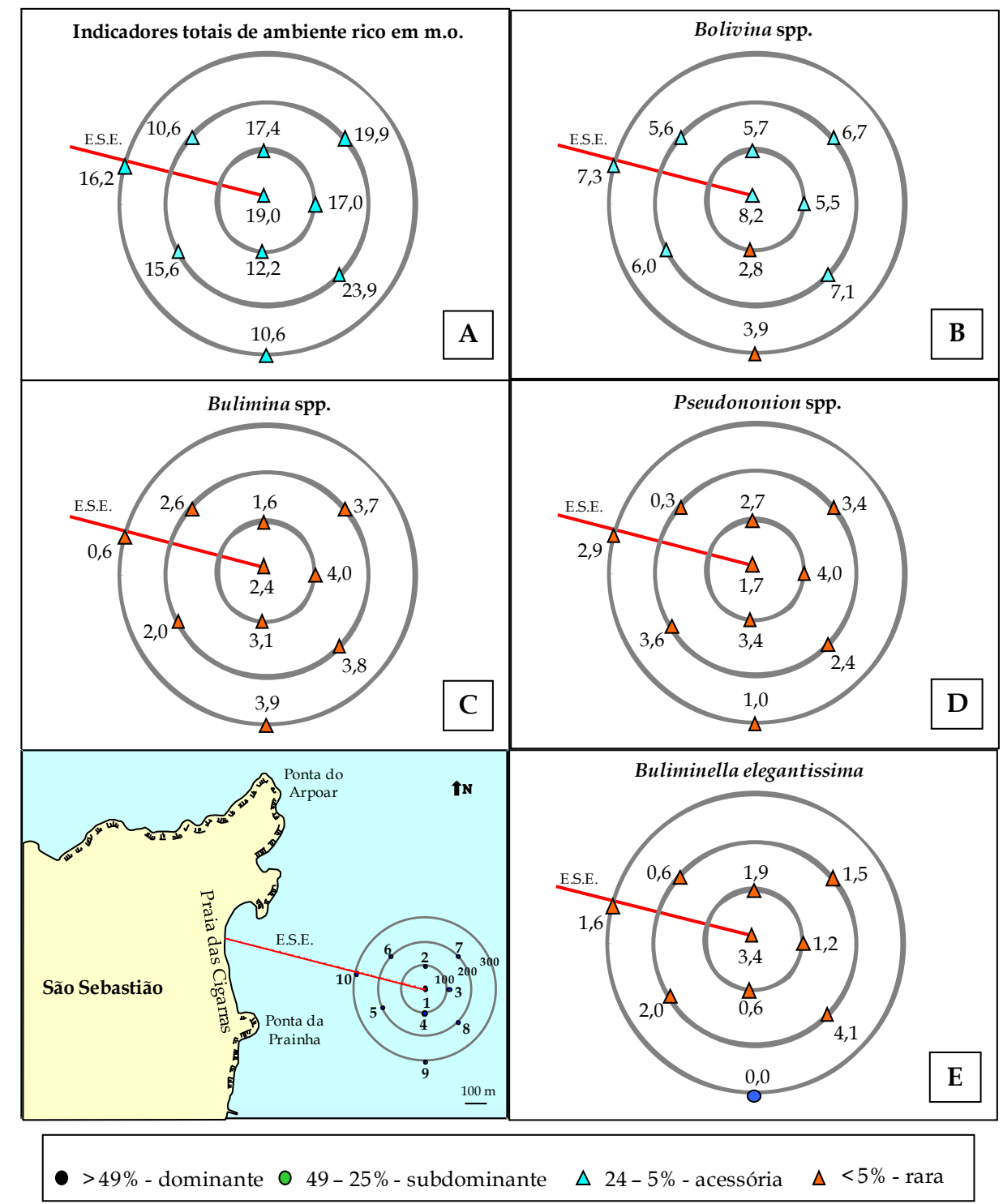

Figura 37: A: Frequência relativa total dos indicadores de matéria orgânica (m.o.). B, C, D e E: Principais representantes de m.o. de 2007. E.S.E.= emissário submarino de esgoto das Cigarras.

Indicadores de oxigênio estão ausentes na estação 8, sendo que nas demais encontram-se em pequenas quantidades e de forma rara (Fig. 38). Os representantes estão distribuídos em 3 gêneros e 4 espécies. A H. boueana é predominante nas estações, sendo seguida por D. bertheloti (\# 6), N. terquemi (\# 3 e 6) e D. williamsoni (\#10 ). 


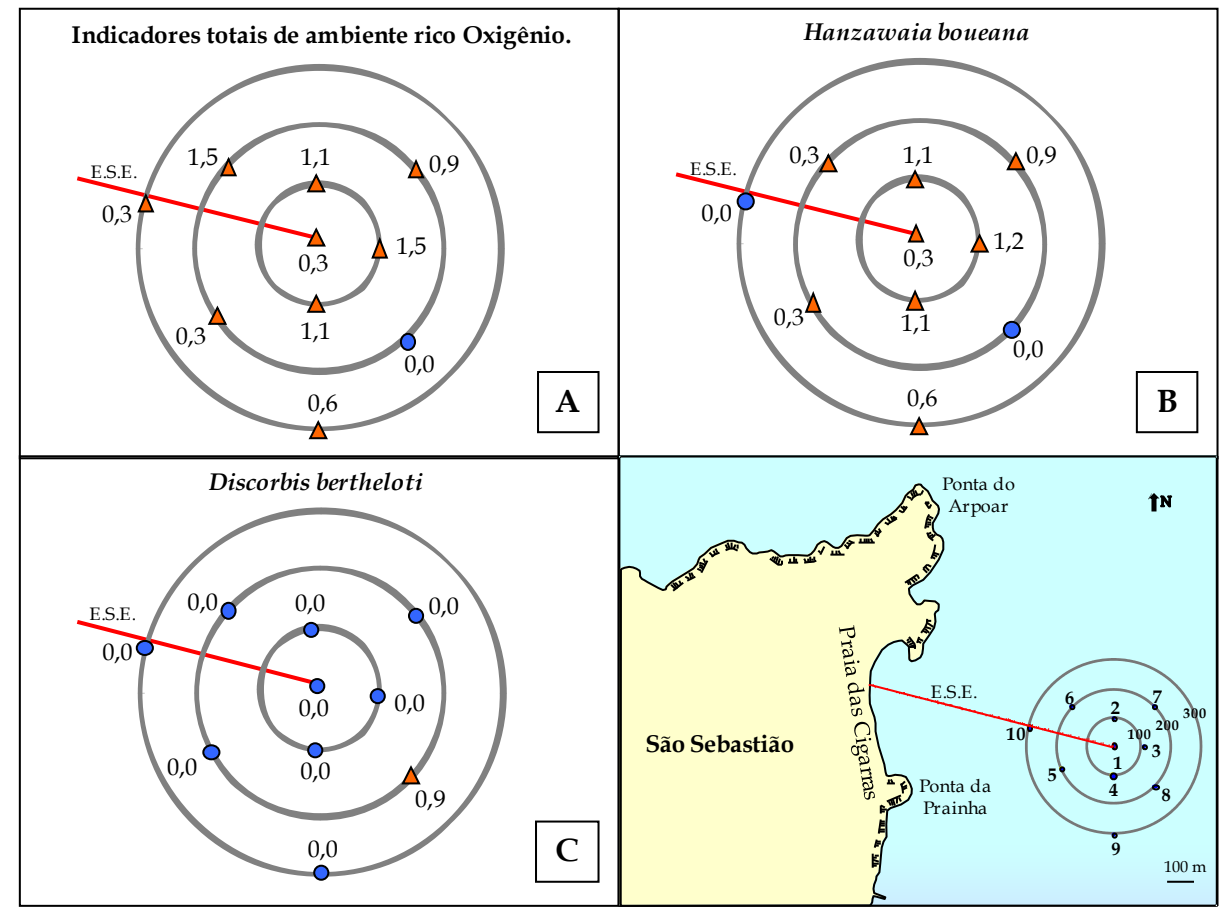

$>49 \%$ - dominante $\bigcirc 49-25 \%$ - subdominante $\Delta 24-5 \%$ - acessória $\Delta<5 \%$-rara

Figura 38: A: Frequência relativa total dos indicadores de ambientes rico em oxigênio. B e C: principais representantes desses indicadores de 2007. E.S.E.= emissário submarino de esgoto das Cigarras.

A análise de agrupamento numérica (modo Q) resulta em 2 grupos distintos (Fig. 39). O primeiro grupo é constituído pela maioria das estações e encontra-se subdividido em 2 subgrupos. Já o segundo grupo é constituído apenas pela amostra 10. Verifica-se dissimilaridade de $-4,65$ entre os grupos.

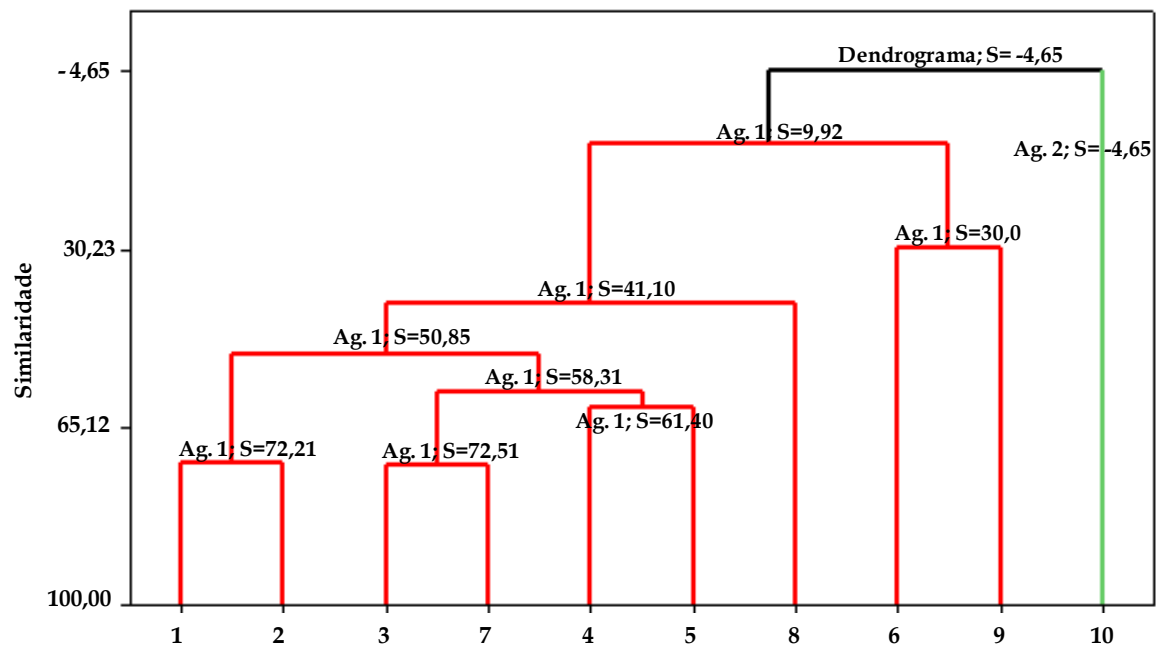

Figura 39: Análise de agrupamento numérica (modo Q) de 2007. Ag.= agrupamento. 
A análise de agrupamento inverso produz 3 associações distintas entre si (Fig. 40). A primeira apresenta alta similaridade $(73,36 \%)$ entre as espécies $A$. parkinsoniana e $A$. tepida, que são caracterizadas por serem eurihalinas. A segunda é caracterizada por indicadores de matéria orgânica (B. pulchella, B. striatula e B. elegantissima) e de influência marinha (P. cananeiaensis), apresentando $66,44 \%$ de similaridade. Já a terceira é constituída por indicadores de matéria orgânica (B. marginata e P. atlanticum), de ambiente costeiro (C. excavatum, C. discoidale, C. poyeanum e C. sp.) e eurihalino (R. rolshauseni), apresentando similaridade inferior aos demais $(6,21 \%)$.Verifica-se fraca dissimilaridade entre 1 e 3 ( $S=-$ 1,43), e forte entre eles e a associação $2(S=-68,25)$.

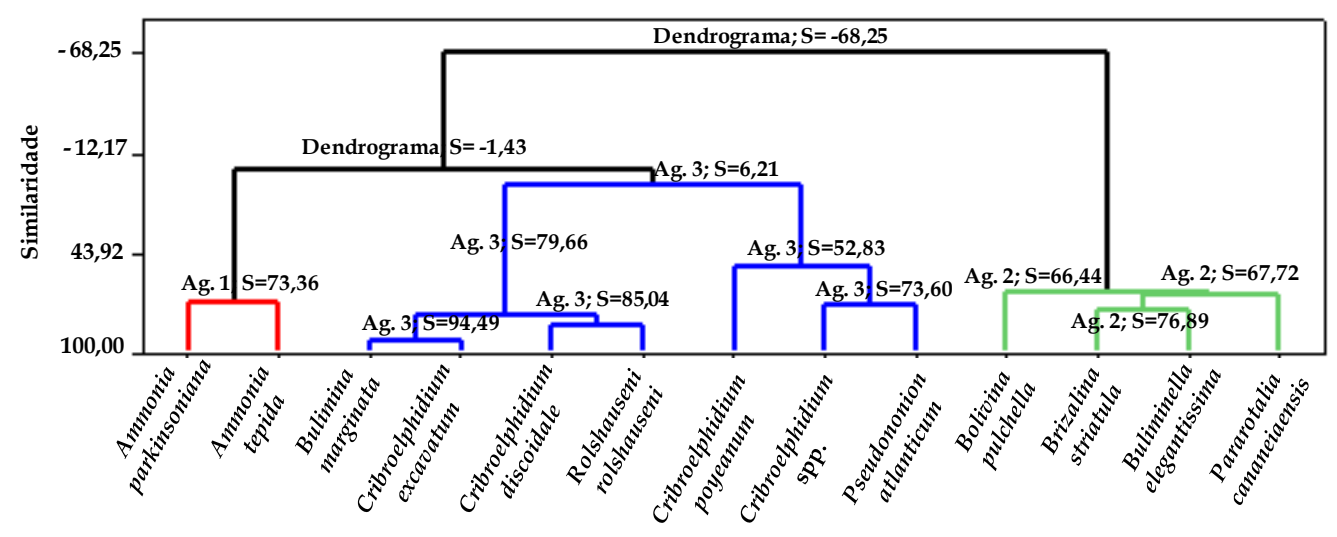

Figura 40: Análise de agrupamento inversa (modo R) de 2007. Ag.= agrupamento.

\subsection{4.b Biocenose}

Os gêneros e espécies, com suas devidas frequências relativas e com seus índices de diversidade de Shannon $\left(\mathrm{H}^{\prime}\right)$ e equitatividades $\left(\mathrm{E}_{\mathrm{H}^{\prime}}\right)$, encontrados na região estão listados no Anexo 04.

Há ocorrência de 20 gêneros e 25 espécies de foraminíferos nas amostras, sendo todos bentônicos. As densidades variam entre 85 (\#10) e 250 indivíduos. $10 \mathrm{cc}^{-1}$ (\#2) (Fig. 41 A). As menores riquezas são encontradas nos pontos amostrais 4 e 9 (8 espécies) e a maior no ponto 2 (16 espécies) (Fig. 41 B).

Os foraminíferos encontrados pertencem às três principais subordens, sendo que a Rotaliina constitui acima de 93\% dos indivíduos (Fig. 41 C). A subordem Miliolina está 
presente na maioria dos pontos enquanto a Textulariina em apenas 5 estações. A ocorrência de ambas as subordens oscila entre rara e escassa (Fig. 41 D e E).

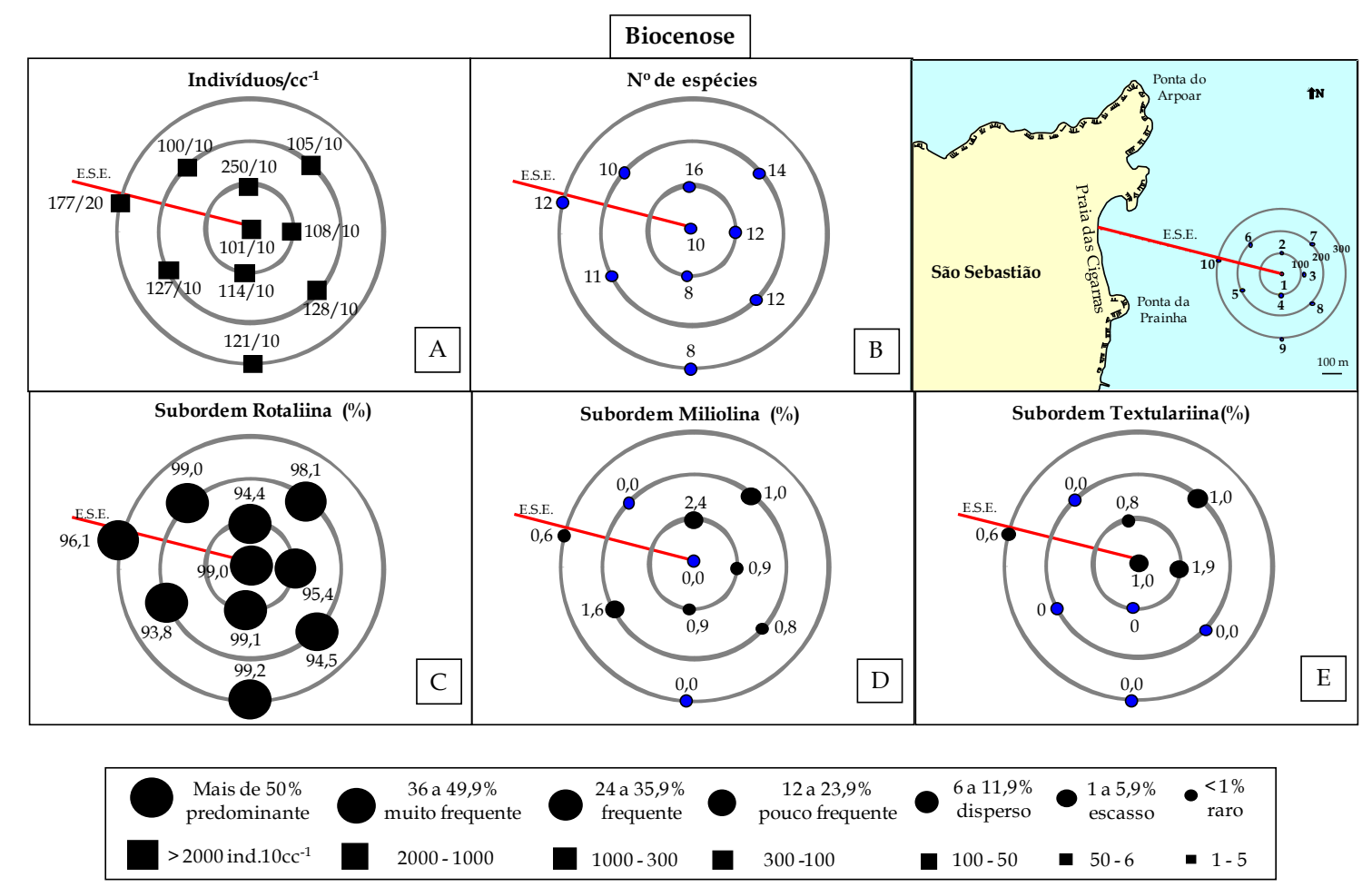

Figura 41: A: densidade, B: riqueza. Frequência relativa das principais subordens de foraminíferos (C, D e E) de 2007. E.S.E.= emissário submarino de esgoto das Cigarras.

A Ammonia é o gênero predominante e apresenta porcentagens que oscilam entre 64,8\% (\#8) e 81,2\% (\#1) dos foraminíferos da amostra. A A. tepida é a espécie mais representativa, sendo sua menor frequência 41,2\% (\#10) e a maior 57\% (\#9). A segunda espécie mais frequente é a A. parkinsoniana, apresentando porcentagens entre 21,1\% (\#8) e 35,6\% (\#1). Em seguida ocorre a B. striatula que perfaz até 10,5\% dos foraminíferos (\#4). Bolivinas e cribroelphidiuns estão presentes em todos os pontos, tendo maior ocorrência de representantes do primeiro grupo (até 10,2\% da amostra no ponto 3).

A partir da análise do índice de diversidade, constata-se que a estação 8 é a mais diversificada $\left(H^{\prime}=1,87\right)$, além de possuir a melhor distribuição de espécies entre seus indivíduos $\left(E_{H}=0,75\right)$. Já a estação 9 possui a menor diversidade $\left(H^{\prime}=1,23\right)$. A estação 7 é que apresenta distribuição menos homogênea das espécies entre seus indivíduos $\left(\mathrm{E}_{\mathrm{H}}=\right.$ $0,56)$. 
A análise morfométrica revela predomínio de carapaças médias (125-250 $\mu \mathrm{m})$, com valores que oscilam entre 48\% (\#10) e 79\% (\#8) (Fig. 42). Carapaças pequenas $(<125 \mu \mathrm{m})$ estão presentes em todos os pontos amostrais, tendo sua menor porcentagem no ponto 8 (15\%) e a maior no ponto $10(50 \%)$. Carapaças grandes $(250-500 \mu \mathrm{m})$ ocorrem em todas as estações, mas em pequenas quantidades que oscilam de 1\% (\#9) a 6\% (\#7 e \#8). Testas muito grandes (> 500 $\mu \mathrm{m})$ estão ausentes.

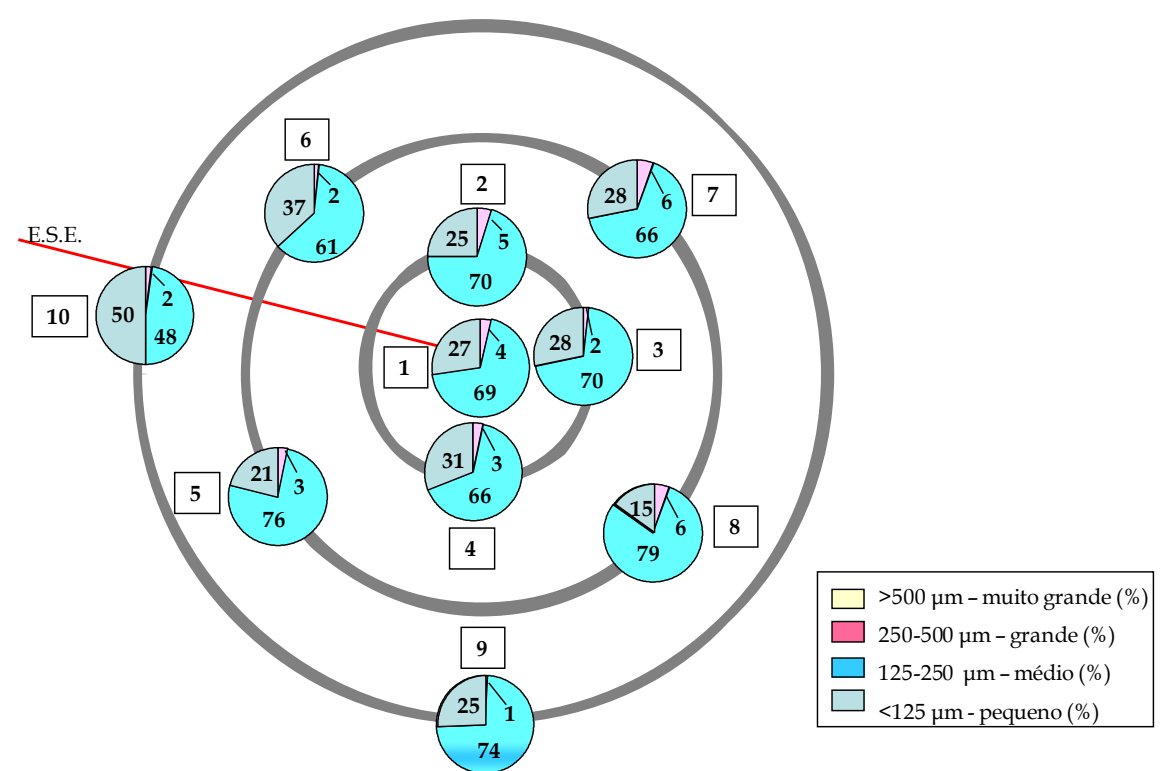

Figura 42: Morfometria das carapaças da biocenose de 2007. E.S.E.= emissário submarino de esgoto das Cigarras.

A partir da análise morfológica observa-se que as testas inteiras predominam em todas as amostras, com valores que oscilam de 57\% (\#3) a 69\% (\#5) das carapaças totais (Fig. 43). As parcialmente fragmentadas estão presentes em todos os pontos amostrais e apresentam porcentagens que variam entre 30\% (\#5) e 41\% (\#3 e 9). Fragmentos estão ausentes nas estações 4, 7 e 8, ocorrendo nas demais estações em pequenas porcentagens, correspondendo no máximo a 3\% da amostra nos pontos 6 e 10. 


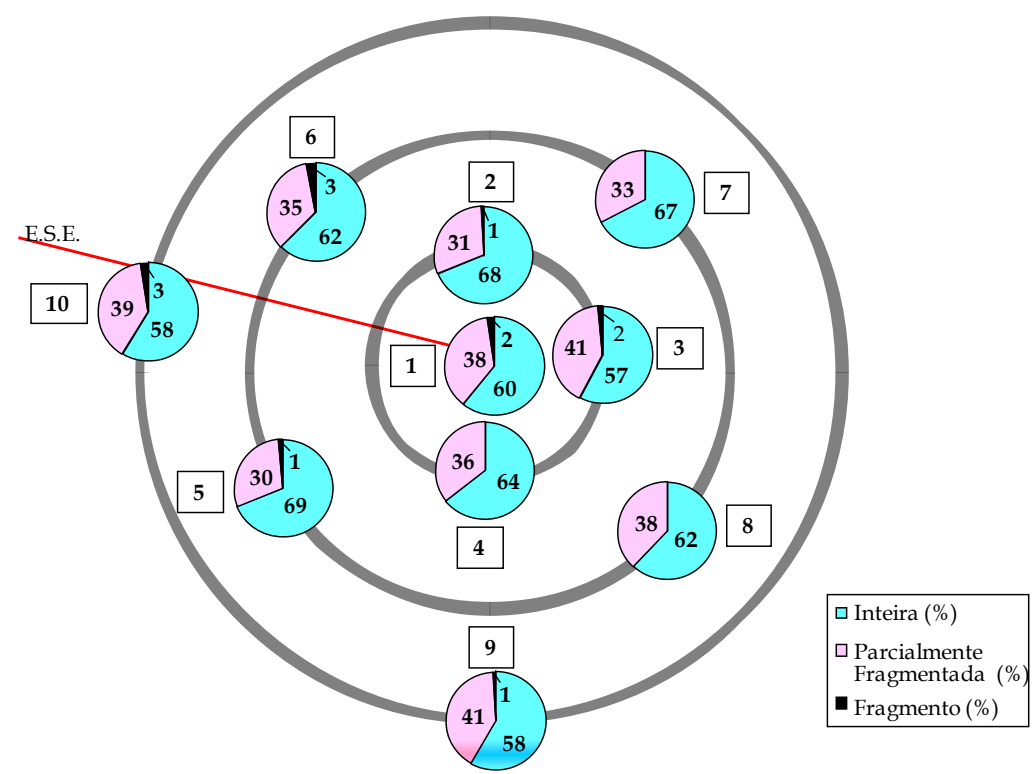

Figura 43: Análise morfológica das carapaças da biocenose de 2007. E.S.E.= emissário submarino de esgoto das Cigarras.

As espécies indicadoras de matéria orgânica (m.o.) e de ambiente rico em oxigênio da biocenose estão representadas na tabela 10.

Tabela 10. Indicadores de ambiente rico em matéria orgânica e em oxigênio da biocenose de 2007.

\begin{tabular}{|c|c|c|c|c|c|c|c|c|c|c|c|}
\hline & $\begin{array}{r}\text { Estação } \\
V=\text { vivo }\end{array}$ & $\begin{array}{c}\# 1 \\
\% \mathrm{~V}\end{array}$ & $\begin{array}{l}22 \\
\% \mathrm{~V}\end{array}$ & $\begin{array}{l}\# 3 \\
\% \mathrm{~V}\end{array}$ & $\begin{array}{l}\# 4 \\
\% \mathrm{~V}\end{array}$ & $\begin{array}{l}\# 5 \\
\% \mathrm{~V}\end{array}$ & $\begin{array}{l}\text { \# } 6 \\
\% \mathrm{~V}\end{array}$ & $\begin{array}{c}\# 7 \\
\% \mathrm{~V}\end{array}$ & $\begin{array}{c}\text { \# } 8 \\
\% \mathrm{~V}\end{array}$ & $\begin{array}{l}\# 9 \\
\% \mathrm{~V}\end{array}$ & $\begin{array}{l}\# 10 \\
\% \mathrm{~V}\end{array}$ \\
\hline \multirow{17}{*}{ 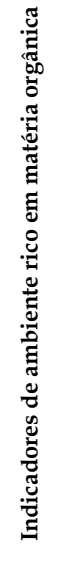 } & Ammotium salsum & 0,0 & 0,0 & 0,0 & 0,0 & 0,0 & 0,0 & 1,0 & 0,0 & 0,0 & 0,0 \\
\hline & Bolivina compacta & 1,0 & 1,2 & 1,9 & 0,9 & 0,8 & 0,0 & 1,0 & 0,0 & 0,0 & 0,0 \\
\hline & Bolivina danvillensis & 0,0 & 1,2 & 0,0 & 0,9 & 0,0 & 0,0 & 0,0 & 0,8 & 0,0 & 0,0 \\
\hline & Bolivina doniezi & 1,0 & 3,2 & 2,8 & 0,9 & 2,4 & 1,0 & 0,0 & 1,6 & 0,8 & 0,0 \\
\hline & Bolivina ordinaria & 1,0 & 2,4 & 4,6 & 0,0 & 3,1 & 2,0 & 2,9 & 1,6 & 1,7 & 0,0 \\
\hline & Bolivina pulchella & 0,0 & 0,4 & 0,0 & 0,0 & 0,0 & 0,0 & 0,0 & 0,0 & 0,0 & 0,0 \\
\hline & Bolivina sp. & 0,0 & 0,4 & 0,9 & 2,6 & 0,0 & 0,0 & 0,0 & 2,3 & 0,0 & 0,6 \\
\hline & Bulimina marginata & 0,0 & 0,4 & 0,0 & 0,0 & 0,0 & 0,0 & 0,0 & 0,0 & 1,7 & 0,6 \\
\hline & Buliminella elegantissima & 0,0 & 2,4 & 0,9 & 0,0 & 2,4 & 3,0 & 0,0 & 2,3 & 1,7 & 4,0 \\
\hline & Brizalina striatula & 7,9 & 9,6 & 4,6 & 10,5 & 4,7 & 5,0 & 4,8 & 10,2 & 2,5 & 3,4 \\
\hline & Cassidulina crassa & 0,0 & 0,0 & 0,9 & 0,0 & 0,0 & 0,0 & 0,0 & 0,0 & 0,0 & 0,0 \\
\hline & Cassidulina sp. & 0,0 & 0,0 & 0,0 & 0,0 & 0,0 & 0,0 & 0,0 & 0,0 & 0,0 & 0,6 \\
\hline & Hopkinsina pacifica & 2,0 & 0,4 & 1,9 & 0,0 & 0,0 & 0,0 & 0,0 & 1,6 & 0,0 & 0,6 \\
\hline & Miliammina fusca & 1,0 & 0,4 & 0,0 & 0,0 & 0,0 & 0,0 & 0,0 & 0,0 & 0,0 & 0,0 \\
\hline & Pseudononion atlanticum & 1,0 & 0,8 & 0,9 & 0,9 & 0,0 & 1,0 & 2,9 & 3,1 & 0,0 & 5,1 \\
\hline & Pseudononion sp. & 0,0 & 0,0 & 0,0 & 0,0 & 0,0 & 0,0 & 0,0 & 0,0 & 0,0 & 0,6 \\
\hline & Total & 14,9 & 22,8 & 19,4 & 16,7 & 13,4 & 12,0 & 12,4 & 23,4 & 8,3 & 15,3 \\
\hline 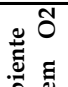 & Discorbis bertheloli & 0,0 & 0,4 & 0,0 & 0,0 & 0,0 & 0,0 & 0,0 & 0,0 & 0,0 & 0,0 \\
\hline ह & Neocornobina terquemi & 2,0 & 0,8 & 0,9 & 0,0 & 0,8 & 0,0 & 0,0 & 0,0 & 0,0 & 0,0 \\
\hline$\varangle .8$ & Total & 2,0 & 1,2 & 0,9 & 0,0 & 0,8 & 0,0 & 0,0 & 0,0 & 0,0 & 0,0 \\
\hline
\end{tabular}


A área de estudo apresenta 9 gêneros e 13 espécies indicadores de matéria orgânica, tendo ocorrência majoritariamente rara, seguida de acessória (Fig. 44). A espécie $B$. striatula é o principal indicador, sendo dominante na maioria das estações (\# 1, \#2, \#4, \#6, \#7 e \#8). O grupo das bolivinas, constituído por B. compacta, B. danvillensis, B. doniezi, B. ordinaria, B. pulchella e B. sp., ocorre em todos os pontos amostrais, sendo majoritários nos pontos 3 e 5. Já o ponto 10 é dominado por pseudononions. A B. elegantissima ocorre em quase todas as estações. Indivíduos de H. pacifica, B. marginata, Cassidulina spp., M. fusca e A. salsum constituem menores contribuições.

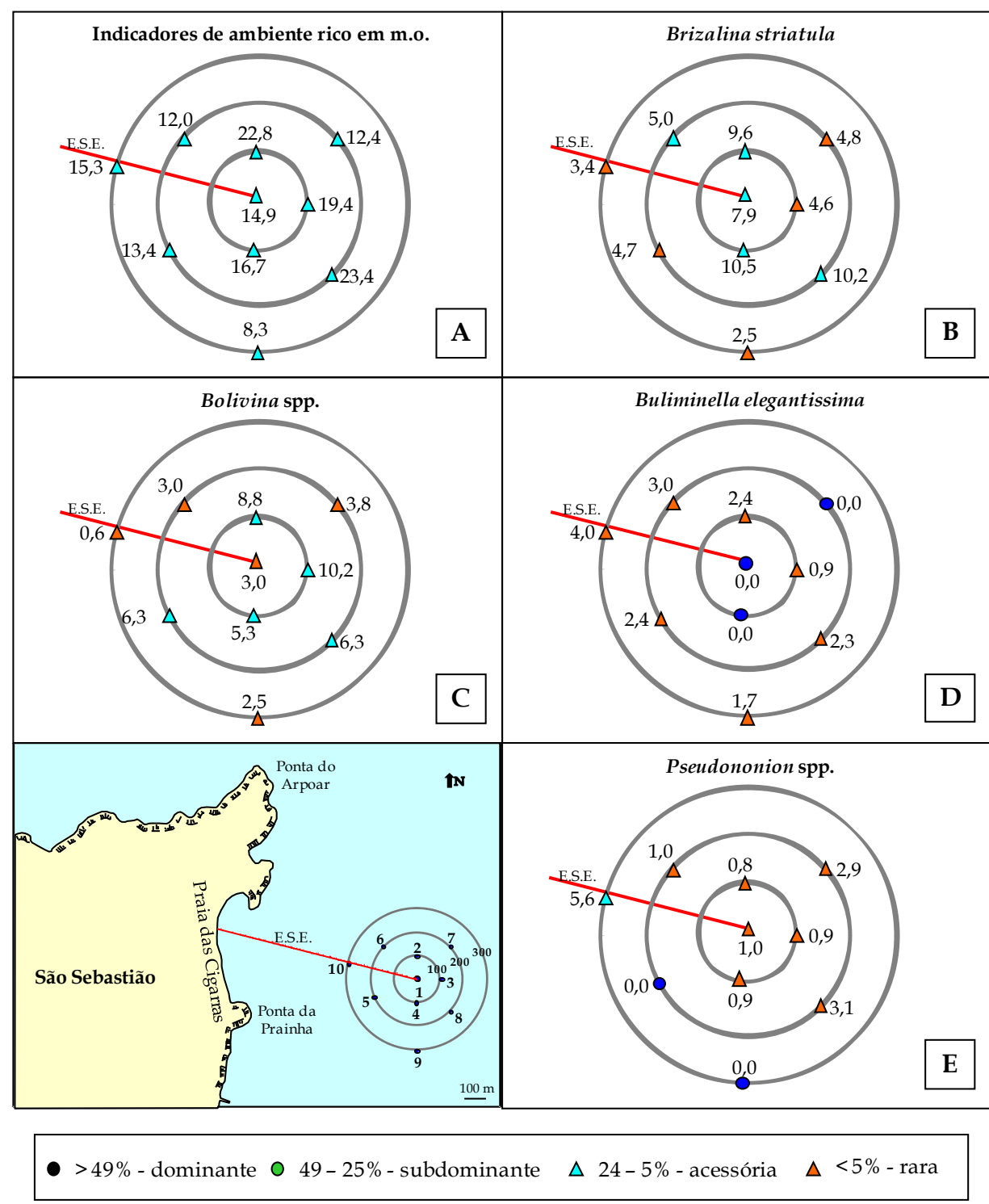

Figura 44: A: Frequência relativa total dos indicadores de ambientes rico em matéria orgânica (m.o.). B, C, D e E: principais indicadores de m.o. de 2007. E.S.E.= emissário submarino de esgoto das Cigarras. 
Representantes de ambiente rico em oxigênio ocorrem de forma rara, ocorrendo apenas nas estações 1, 2, 3 e 5 (Fig. 45 A). Espécimes de $N$. terquemi estão presentes nesses quatro pontos amostrais com frequências relativas que variam entre 0,8\% e 2,0\% (Fig. 45 B). Já a espécie $D$. bertheloti ocorre apenas no ponto 2 (0,4\%) (Fig. 45 C).

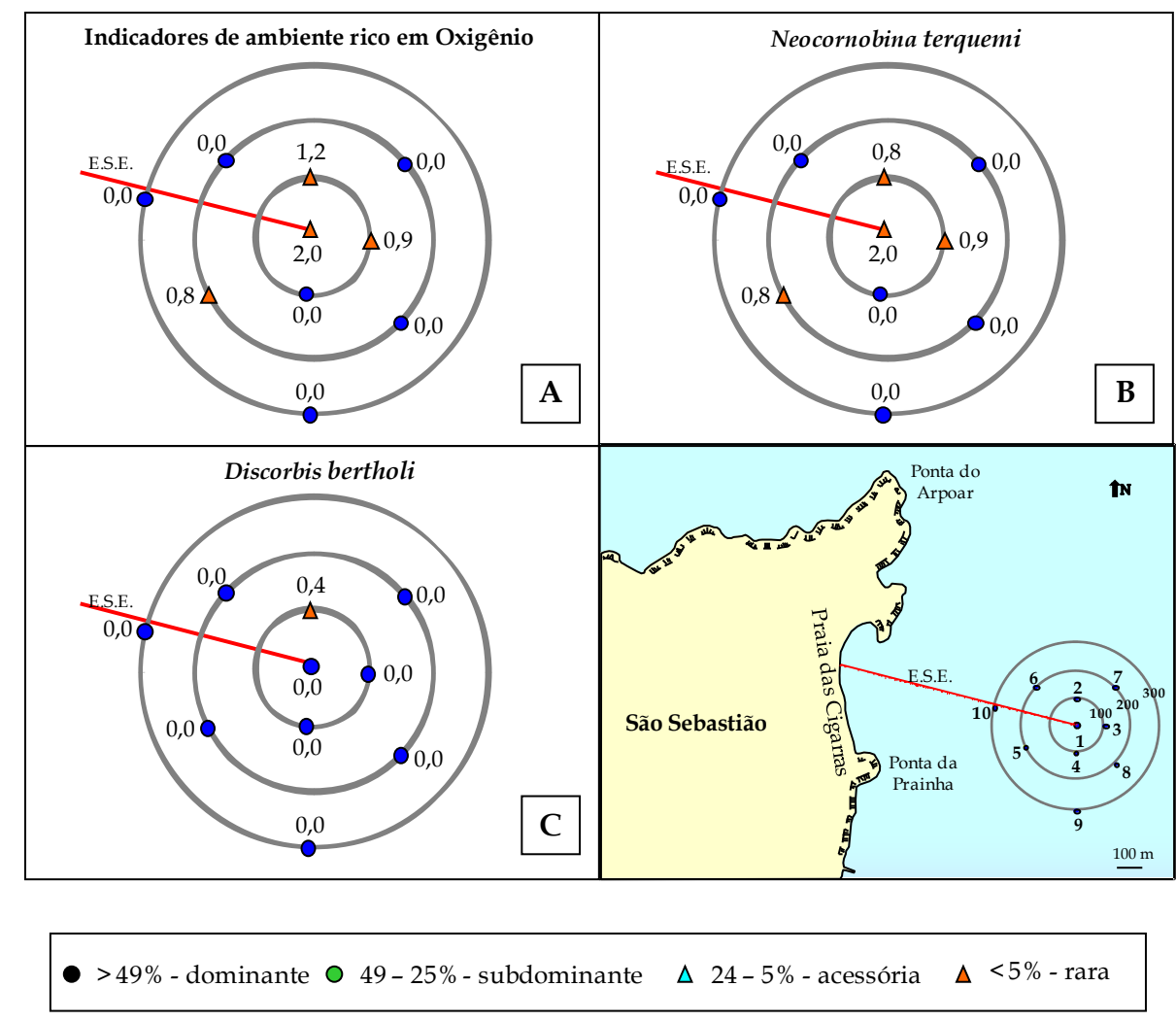

Figura 45: A. Frequência relativa total dos indicadores de oxigênio. B e C: principais representantes desses indicadores de 2007. E.S.E.= emissário submarino de esgoto das Cigarras.

A análise de agrupamento numérica (modo Q) é constituída por 2 grupos que apresentam dissimilaridade entre si $(\mathrm{S}=-33,06)$ (Fig. 46). O grupo 1 é constituído por 2 subgrupos: o primeiro é formado pelas estações 1, 5 e 10, o segundo pelas estações 3, 6, 7 e 9. Já o grupo 2 é constituído pelos pontos 2, 4 e 8. 


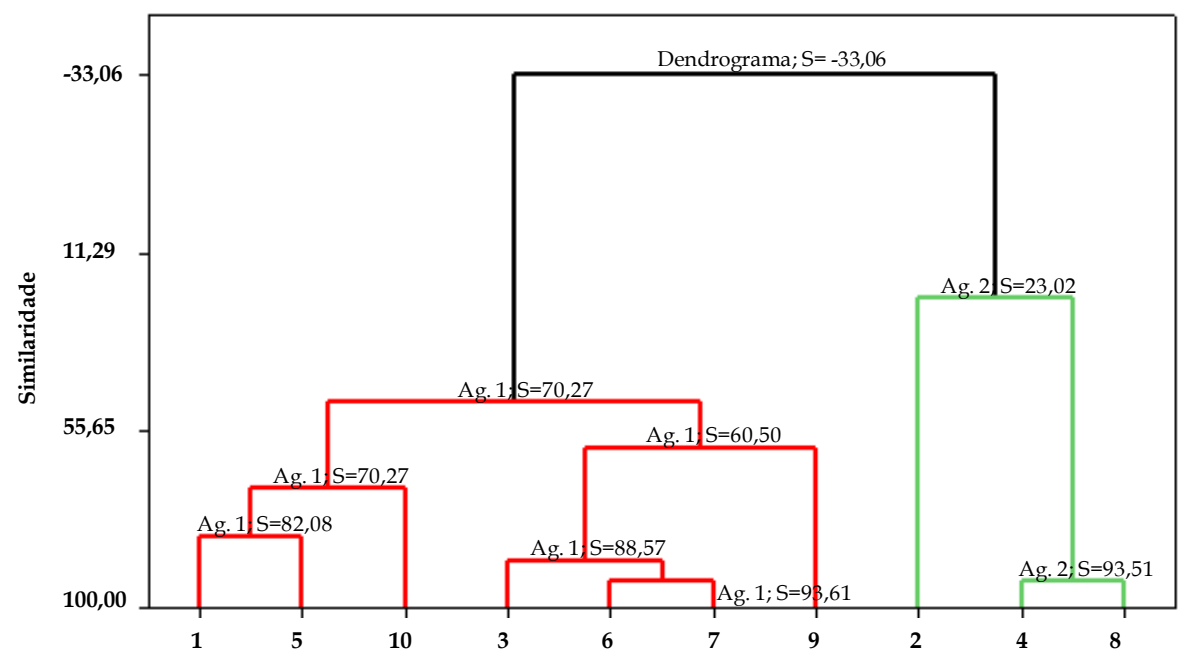

Figura 46: Análise de agrupamento numérica (modo Q) de 2007. Ag.= agrupamento.

A análise de agrupamento inversa (modo $\mathrm{R}$ ) revela uma única associação constituída pelas principais espécies, sendo caracterizada por foraminíferos euribióticos (A. parkinsoniana e A. tepida) e indicador de matéria orgânica (B. striatula) (Fig. 47). A similaridade entre as espécies do gênero Ammonia é de 89,1\%. Já em relação às espécies desse gênero e a B. striatula, a similaridade é de 63,13\%.

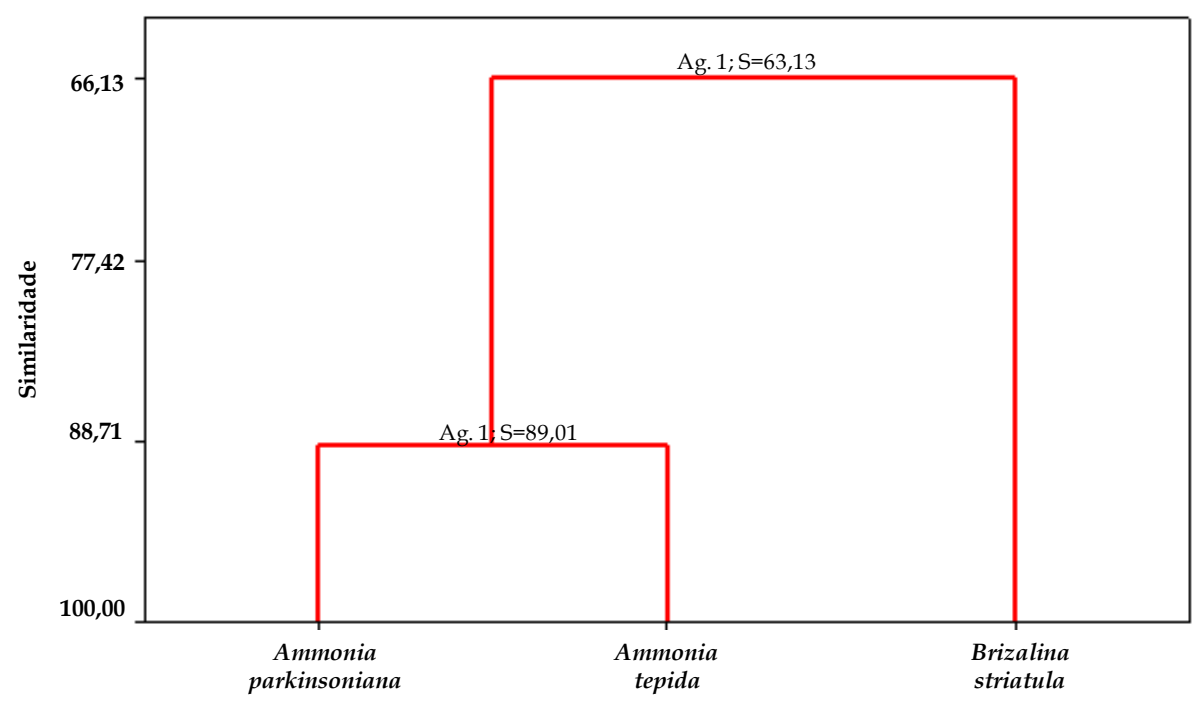

Figura 47: Análise de agrupamento inversa (modo R) de 2007. Ag.= agrupamento. 


\subsection{4.c Comparação com os dados da tanatocenose de 2007}

De acordo com o número de espécie, observa-se maior riqueza na tanatocenose, apresentando 14 espécies a mais que a biocenose. Em ambas, a estação de maior riqueza é a 2 e o ponto 8 apresenta a maior diversidade.

Tanto nos vivos quanto nos mortos há predomínio de rotalíneos de carapaças médias e do gênero Ammonia. Indivíduos de P. cananeiaensis são abundantes somente nos mortos, chegando a ter 72 vezes mais indivíduos dessa espécie que a biocenose. Os resultados encontrados a partir do cálculo do Teste de Kruskal Wallis confirmam a existência de diferença extremamente significativa entre as assembléias de mortos e vivos $(\mathrm{p}<0,01)($ Fig. 48).

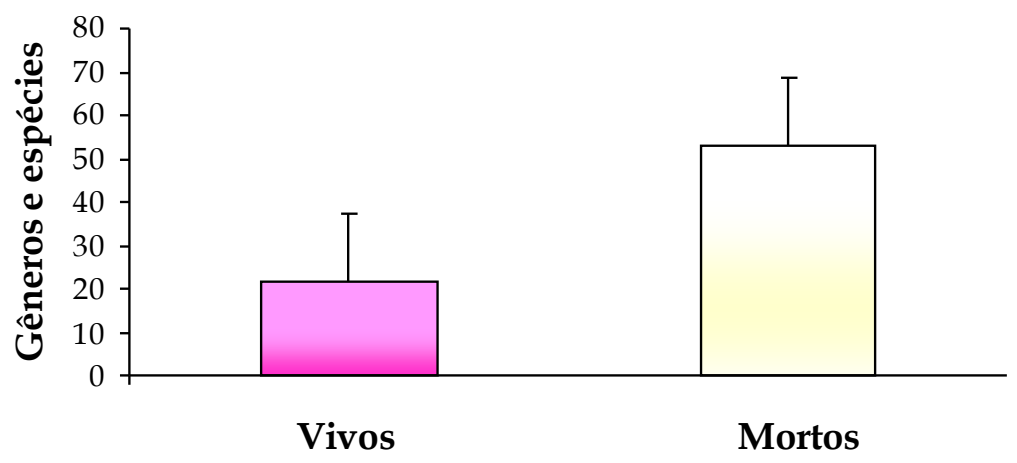

Figura 48: Relação entre a média do número de táxons (gêneros e espécies), e seu respectivo desvio-padrão, da tanatocenose e da biocenose de 2007. MNT= número de táxons.

\subsection{Análise Canônica}

\subsubsection{Análise Canônica das Tanatocenoses de 2006, 2007 e controles}

Ambos os vetores possuem o mesmo tamanho, indicando que não há ordem de importância entre essas duas variáveis ambientais (Fig. 49). O diâmetro médio (D. médio) está associado ao eixo 1, enquanto que o carbono orgânico (Corg) está associado ao eixo 2. Juntos, os eixos explicam 100\% das relações entre as principais espécies e as variáveis ambientais, sendo $67,1 \%$ explicados pelo primeiro eixo (Tabela 11). 
Tabela 11. Dados da análise canônica das tanatocenoses de 2006, 2007 e controles.

\begin{tabular}{|lccccc|}
\hline \multicolumn{1}{|c}{ Eixos } & 1 & 2 & 3 & 4 & Inércia total \\
\hline Auto-valores & 0,011 & 0,005 & 0,018 & 0,013 & 0,085 \\
Correlações espécies-ambientes & 0,766 & 0,659 & 0,0 & 0,0 & \\
& & & & & \\
Variância da porcentagem cumulativa & & & & & \\
dos dados das espécies & 12,7 & 18,9 & 39,8 & 55,1 & \\
da relação espécie-ambiente & 67,1 & 100 & 0,0 & 0,0 & \\
\hline
\end{tabular}

As espécies B. striatula, B. marginata, C. excavatum, $C$, discoidale e $R$. rolshauseni estão associados negativamente ao eixo 1, estando relacionados, portanto, a maiores quantidades de areia. Inversamente há ocorrência de $P$. cananeianeis, C. crassa, $P$. atlanticum, B. doniezi, C. advenum e B. elegantissima. Já as espécies C. poyeanum, B. pulchella, A. parkinsoniana, A. tepida e B. ordinaria associam-se positivamente a maiores teores de carbono orgânico, enquanto que $P$. atlanticum relaciona-se a menores teores desse elemento.

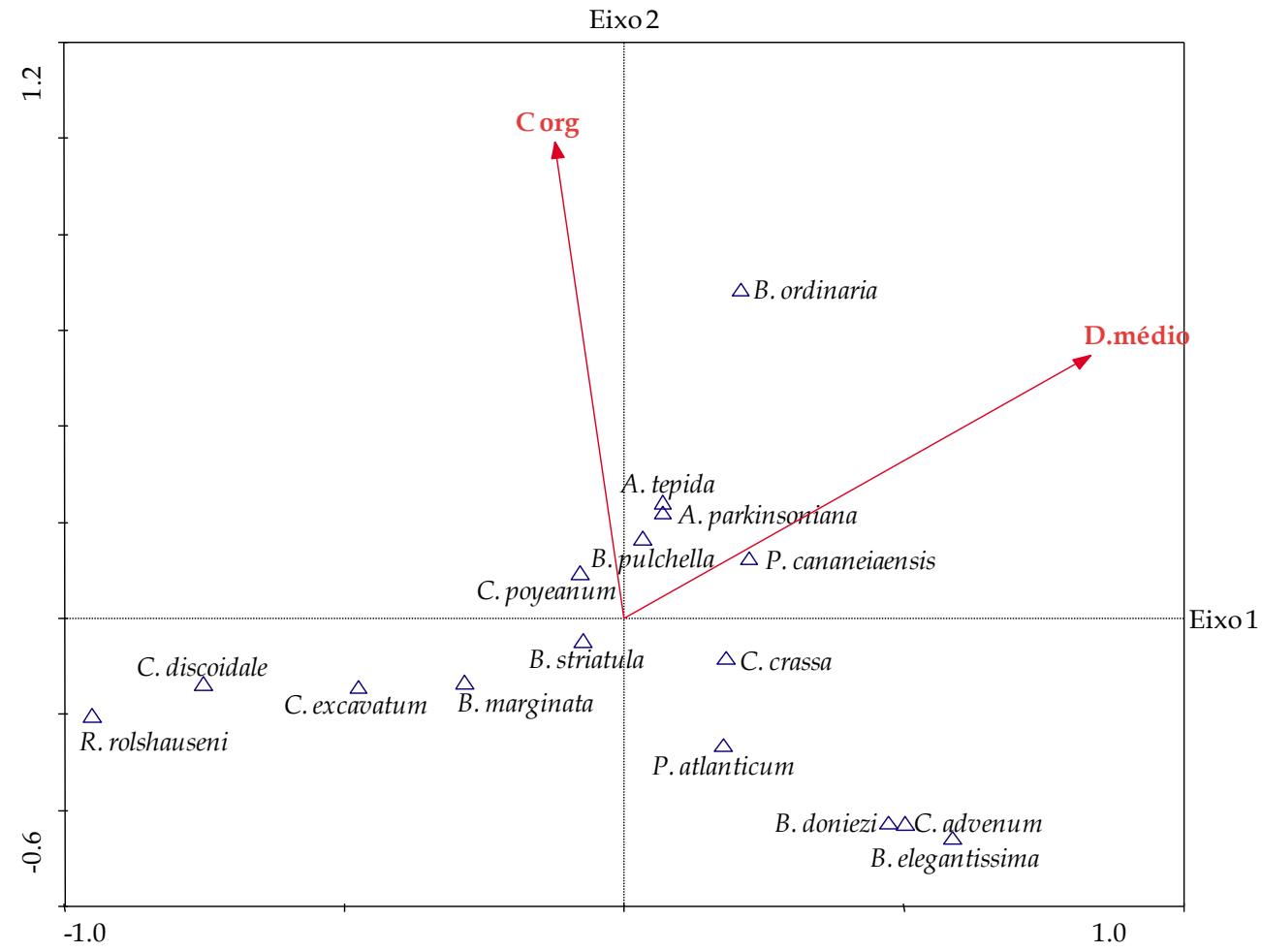

Figura 49: Análise canônica das tanatocenoses e parâmetros abióticos de 2006, 2007 e controles. 
Os pontos 6 (2006), 10 (2007) e controle 1 estão associados positivamente ao eixo 1, ou seja, aos maiores teores de lama (Fig. 50). Já as estações 4 de 2006 e estações 3 e 7 de 2007 associam-se negativamente ao diâmetro médio. A maioria dos pontos amostrais de ambos os anos, assim como o controle 2, associa-se aos menores teores de carbono orgânico.

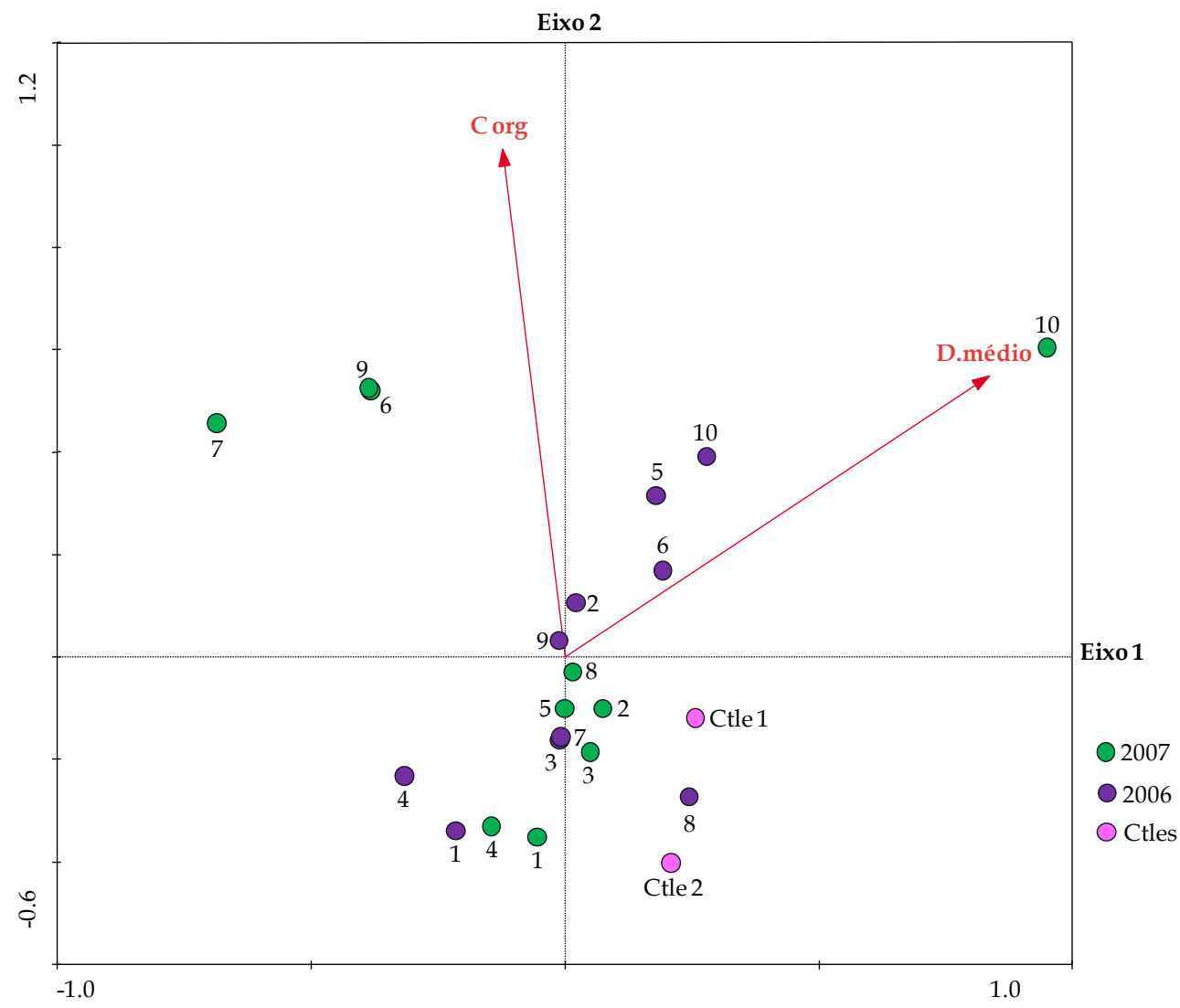

Figura 50: Análise canônica das estações e parâmetros abióticos de 2006, 2007 e controles.

\subsubsection{Análise Canônica das Biocenoses de 2006, 2007 e controles}

Ambos os vetores possuem o mesmo tamanho, indicando que não há ordem de importância entre essas duas variáveis ambientais (Fig. 51). O diâmetro médio (D. médio) está associado ao eixo 1, enquanto que o enxofre (S) está associado ao eixo 2. Juntos, os eixos explicam 100\% das relações entre as principais espécies e as variáveis ambientais, sendo 55,5\% explicados pelo primeiro eixo (Tabela 12). 
Tabela 12. Dados da análise canônica das biocenoses de 2006, 2007 e controles.

\begin{tabular}{|lccccc|}
\hline \multicolumn{1}{|c}{ Eixos } & 1 & 2 & 3 & 4 & Inércia total \\
\hline Auto-valores & 0,026 & 0,021 & 0,046 & 0,035 & 0,198 \\
Correlações espécies-ambientes & 0,836 & 0,638 & 0,0 & 0,0 & \\
& & & & & \\
Variância da porcentagem cumulativa & & & & & \\
dos dados das espécies & 13,0 & 23,4 & 46,9 & 64,4 & \\
da relação espécie-ambiente & 55,5 & 100 & 0,0 & 0,0 & \\
\hline
\end{tabular}

A espécie $P$. atlanticum associa-se positivamente ao eixo 1, indicando maior afinidade com sedimentos lamosos. Já C. poyeanum e B. ordinaria estão associados a maiores quantidades de areia. A B. elegantissima sofre influência tanto dos teores de enxofre quanto do diâmetro médio. A A. tepida e A. parkinsoniana estão associadas a maiores teores de enxofre, enquanto que B. doniezi, $B$. striatula associam-se negativamente a esse elemento.

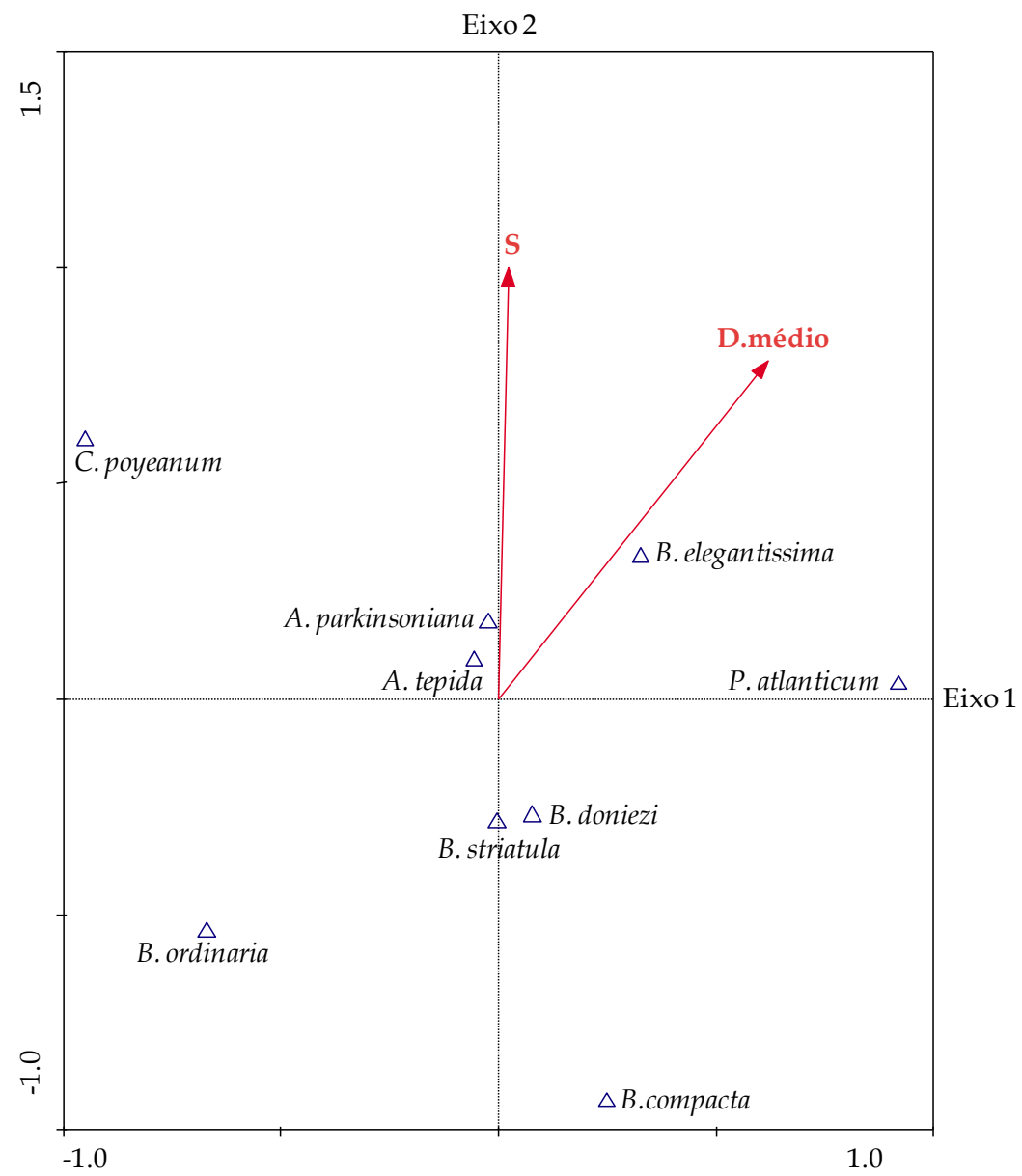

Figura 51: Análise canônica das biocenoses e parâmetros abióticos de 2006, 2007 e controles. 
Os controles estão associados a maiores teores de lama, assim como as estações 2 (2007), 8 (2006) e 10 (2007) (Fig. 52). Já os pontos 4, 7 e 9 de 2006, e 1, 5 e 8 de 2007 estão associados a maiores teores de areia. As estações 2, 5, 6 e 10 de 2006 estão associadas a maiores teores de enxofre, e o restante dos pontos amostrais relaciona-se com menores teores desse elemento.

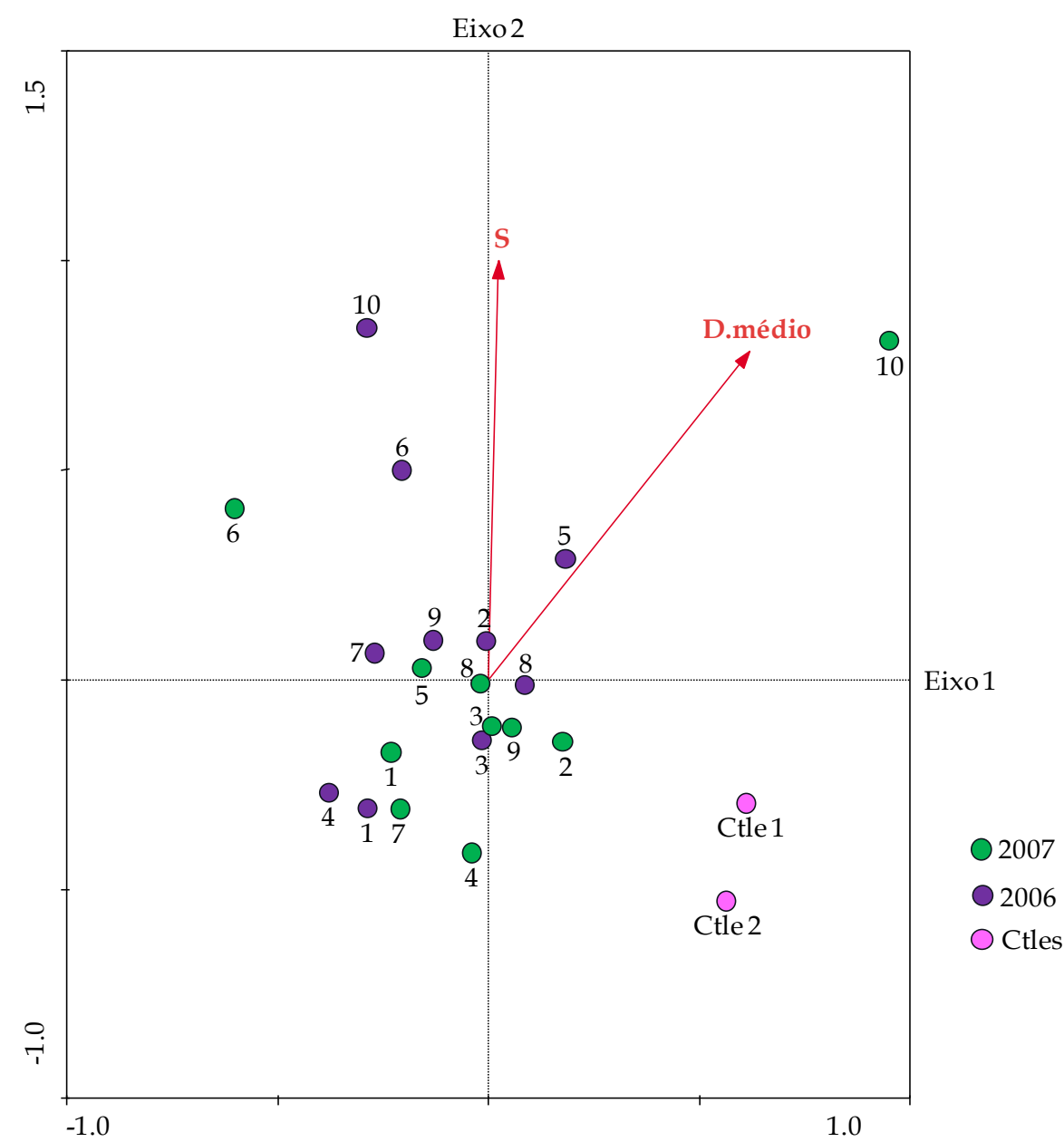

Figura 52: Análise canônica das estações e parâmetros abióticos de 2006, 2007 e controles. 


\subsection{Pontos Controles}

\subsubsection{Parâmetros Granulométricos}

Os dados granulométricos estão apresentados na tabela 13.

Tabela 13. Dados granulométricos dos pontos controles. $P S=$ pobremente selecionado.

\begin{tabular}{|c|c|c|c|c|c|c|c|c|c|c|c|c|c|c|c|c|}
\hline \multirow[b]{2}{*}{ Amostra } & \multirow{2}{*}{$\begin{array}{l}\text { D. Médio } \\
\text { (Ф) }\end{array}$} & \multirow{2}{*}{$\begin{array}{c}\text { Grau } \\
\text { de seleção o }\end{array}$} & \multirow{2}{*}{$\begin{array}{c}\text { Classificação } \\
\text { Folk \& Ward (1957) }\end{array}$} & \multirow{2}{*}{$\begin{array}{l}\text { Classificação } \\
\text { Shepard (1954) }\end{array}$} & \multicolumn{12}{|c|}{ G R A N U L O ME T R I A (\%) } \\
\hline & & & & & Seixos & & s Total & $\begin{array}{l}\text { Muito } \\
\text { grossa }\end{array}$ & Grossa & Média & Fina & $\begin{array}{l}\text { Muito } \\
\text { fina }\end{array}$ & Total & Silte & Argila & a Total \\
\hline \# 01 & 4,47 & 1,70 & PS & Areia síltica & 0,00 & 0,00 & 0,00 & 0,02 & 0,52 & 0,81 & 6,56 & 49,23 & 57,14 & 35,71 & 7,15 & 42,86 \\
\hline \# 02 & 4,10 & 1,56 & PS & Areia & 0,00 & 0,06 & 0,06 & 0,09 & 0,45 & 0,84 & 3,75 & 72,00 & 77,13 & 16,77 & 6,04 & 22,81 \\
\hline Máximo & 4,47 & 1,70 & & & 0,00 & 0,06 & 0,06 & 0,09 & 0,52 & 0,84 & 6,56 & 72,00 & 77,13 & 35,71 & 7,15 & 42,86 \\
\hline Mínimo & 4,10 & 1,56 & & & 0,00 & 0,00 & 0,00 & 0,02 & 0,45 & 0,81 & 3,75 & 49,23 & 57,14 & 16,77 & 6,04 & 22,81 \\
\hline Média & 4,29 & 1,63 & & & 0,00 & 0,03 & 0,03 & 0,06 & 0,49 & 0,83 & 5,16 & 60,62 & 67,14 & 26,24 & 6,60 & 32,84 \\
\hline
\end{tabular}

A estação 1 é constituída por areia síltica e a estação 2 por areia (Shepard, 1954) (Fig. 53 A). Em ambos os pontos os sedimentos são pobremente selecionados (Folk e Ward, 1957). Os pontos controles são majoritariamente constituídos por sedimentos arenosos, sendo que a fração de areia fina perfaz 57,14\% da estação 1 e 77,13\% da estação 2 (Fig. 53 B). Já os sedimentos lamosos são representados principalmente pela fração silte. Cascalhos ocorrem apenas no ponto 2 e em porcentagens extremamente pequenas $(0,06 \%)$.

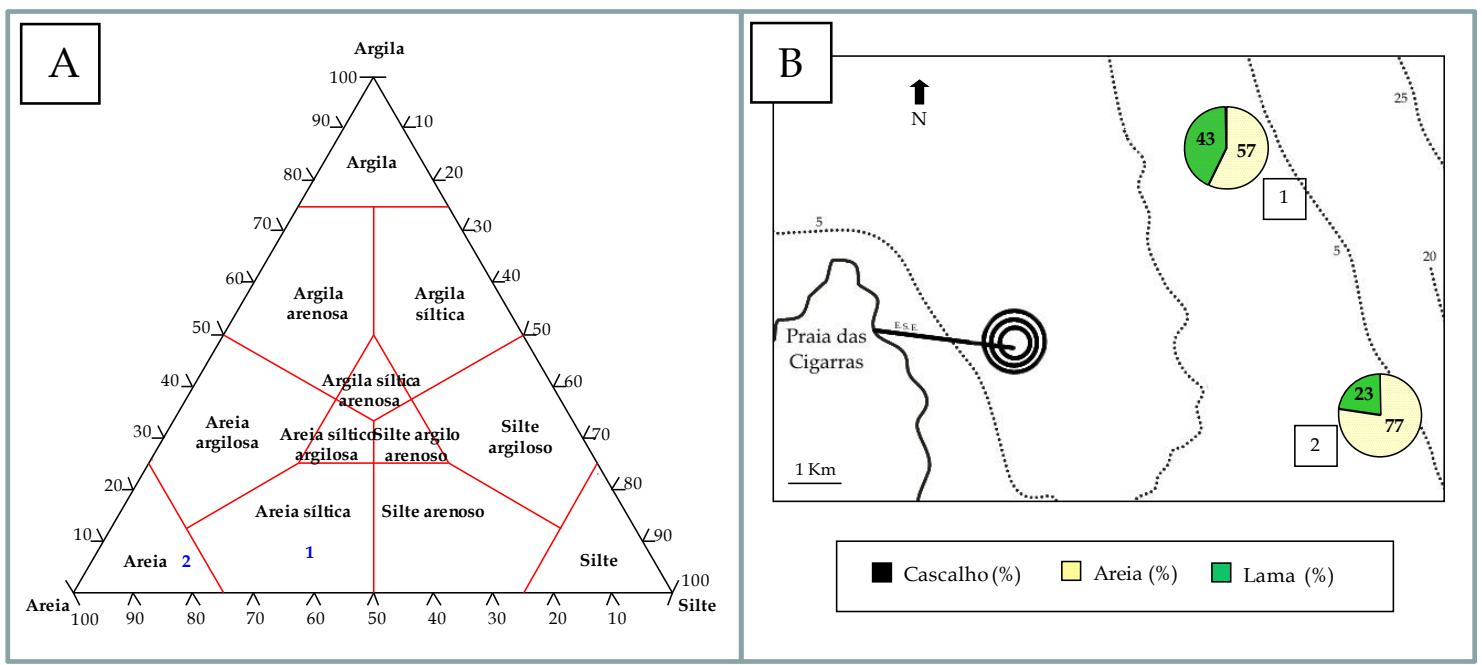

Figura 53: A: Classificação granulométrica por Shepard (1954). B: Granulometria dos sedimentos dos pontos controles. 


\subsubsection{Parâmetros Geoquímicos}

Os dados geoquímicos dos nutrientes encontram-se dispostos na tabela 14 .

Tabela 14. Dados Geoquímicos dos nutrientes dos pontos controles.

\begin{tabular}{|cccccccc|}
\hline Estação & $\mathbf{C a C O 3 ~ ( \% )}$ & $\begin{array}{c}\text { Classificação dos sedimentos } \\
\text { (Larsonneur , 1977) }\end{array}$ & $\mathbf{S ~ ( \% )}$ & $\mathbf{C}$ org (\%) & $\mathbf{C / S}$ & $\mathbf{N}(\mathbf{\%})$ & $\mathbf{C} / \mathbf{N}$ \\
\hline $\mathbf{1}$ & 11,97 & Litoclástico & 0,23 & 1,18 & 5,11 & 0,13 & 9,04 \\
$\mathbf{2}$ & 8,02 & Litoclástico & 0,16 & 0,58 & 3,59 & 0,17 & 3,48 \\
\hline
\end{tabular}

Os pontos controles apresentam teores de carbonato inferiores a 30\%, sendo, portanto classificados como litoclásticos (Larsonneur, 1977).

O ponto controle 1 apresenta teores de carbono orgânico e de enxofre superiores ao controle 2, enquanto que em relação ao nitrogênio ocorre o inverso (Fig. 54).

De acordo com o cálculo da razão C/S, enquanto o ponto 2 apresenta características de deposição em período de anoxia, o ponto 1, tanto os sedimentos quanto a coluna d'água são considerados óxicos (Fig. 54).

De acordo com a razão $\mathrm{C} / \mathrm{N}$, constata-se que o ponto 1 apresenta matéria orgânica de origem mista, enquanto que o ponto 2 apresenta origem marinha (Fig. 54). 


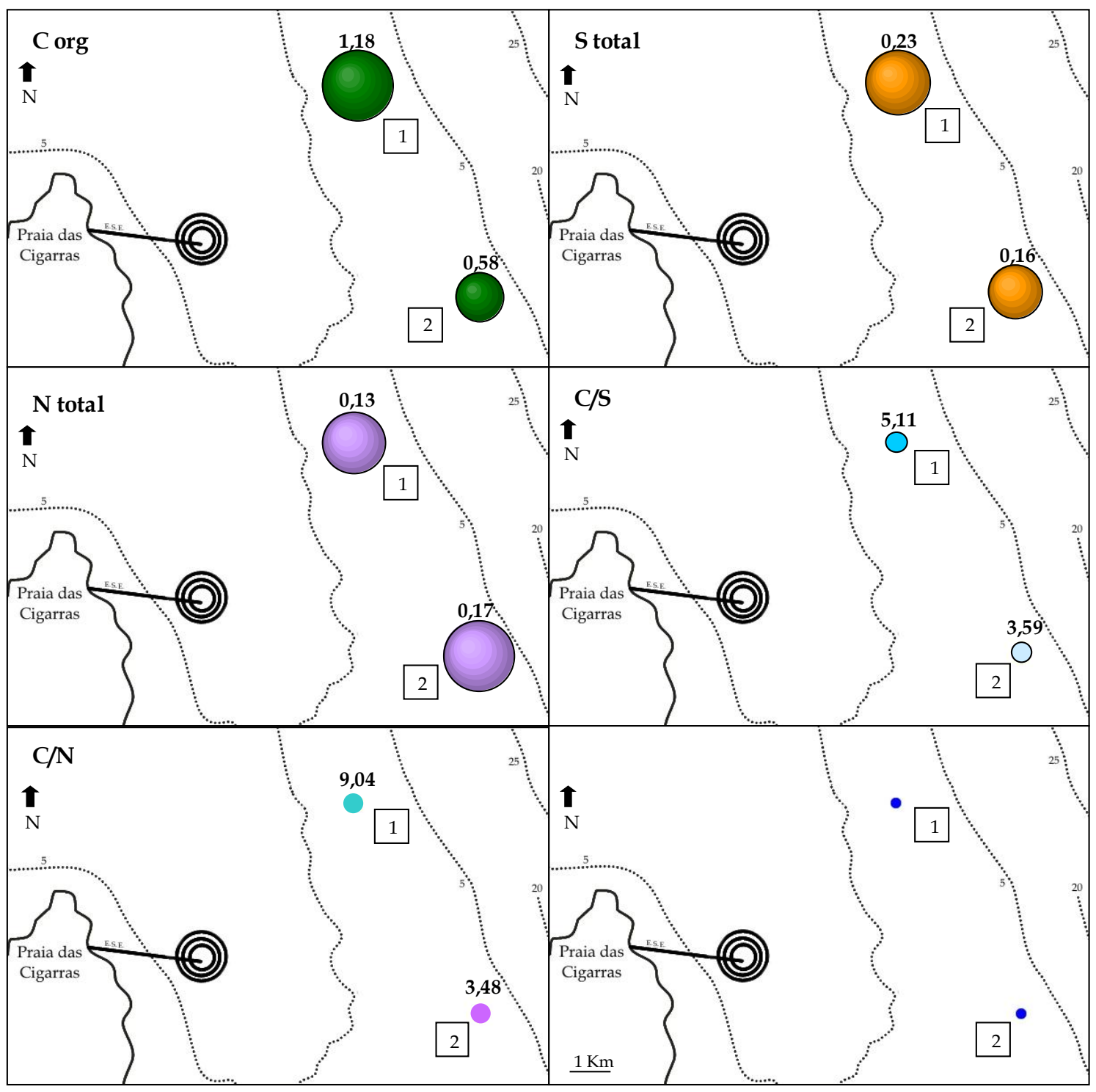

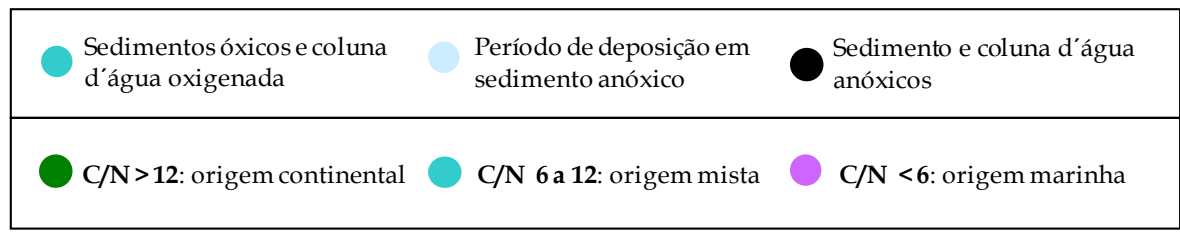

Figura 54: Porcentagens de carbono orgânico, enxofre total, nitrogênio total e razões $C / S$ e $C / N$ dos sedimentos dos pontos controles. E.S.E.= emissário submarino de esgoto das Cigarras.

As concentrações de HPAs encontradas nos pontos controles estão listadas na tabela 15. 
Tabela 15. Concentrações de HPAs $(\mu \mathrm{g} / \mathrm{Kg})$ e taxas de recuperação dos surrogates utilizados nas análises dos sedimentos dos pontos controles. $L Q=$ limite de quantificação em $\mu \mathrm{g} / \mathrm{Kg}$. Em negrito são os valores acima do limite de quantificação.

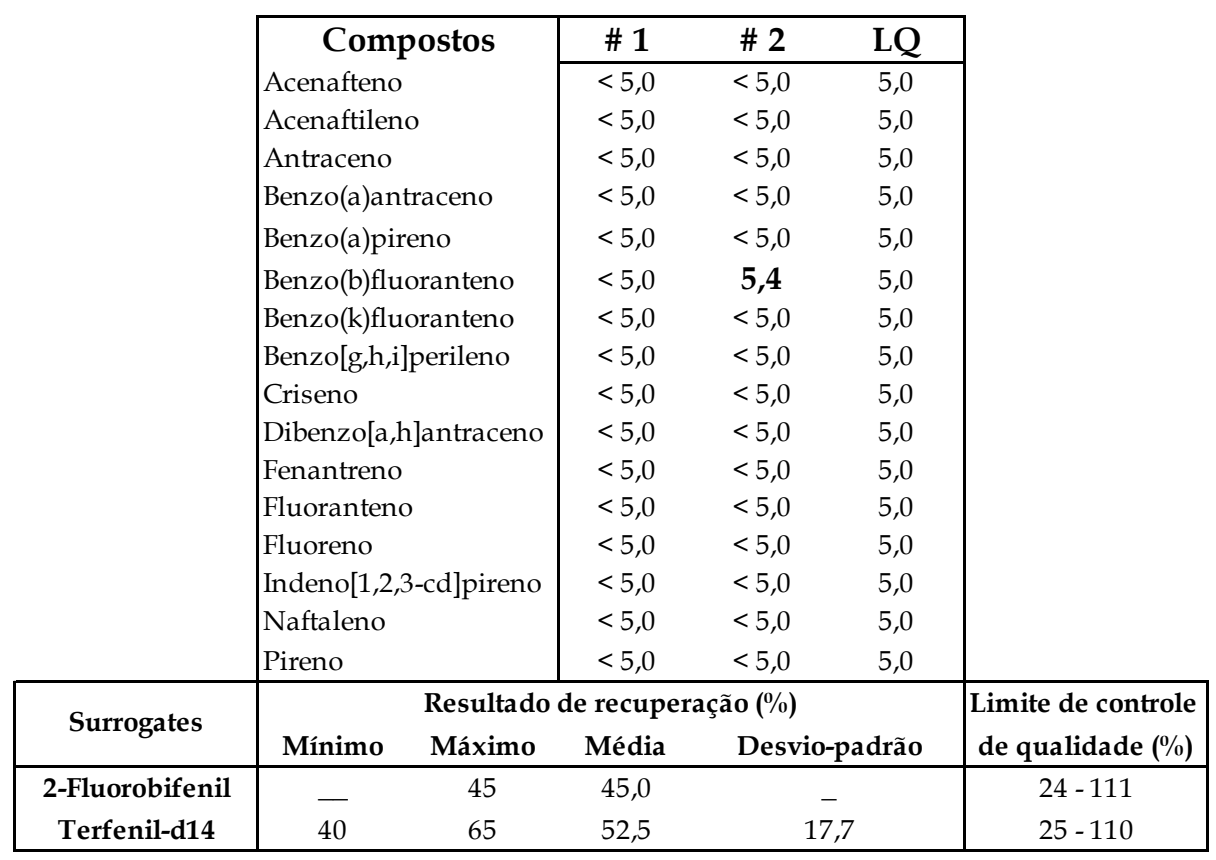

A partir dos resultados obtidos, constata-se que apenas o controle 2 apresenta valor acima do limite de quantificação, sendo representado pelo Benzo(b)fluoranteno (5,4 $\mu \mathrm{g} / \mathrm{Kg})$.

As taxas de recuperação dos surrogates utilizados encontram-se dentro do limite de qualidade. Não foi possível calcular a taxa de recuperação do ponto controle 1 para o 2Fluorobifenil devido à interferências na matriz.

Os valores obtidos para os LCS e brancos do método encontrados durante a análise das amostras de sedimentos do estudo estão dispostas no Anexo 06. Todos os valores encontram-se dentro do limite de controle de qualidade.

\subsubsection{Análise dos foraminíferos}

\subsection{3.a Tanatocenose}

Os gêneros e espécies encontrados na área de amostragem dos pontos controles estão listados no Anexo 07, com suas frequências relativas e com seus índices de diversidade de Shannon $\left(\mathrm{H}^{\prime}\right)$ e equitatividades $\left(\mathrm{E}_{\mathrm{H}^{\prime}}\right)$. 
O ponto controle 1 possui densidade de 2456 indivíduos. 10cc-1 (Fig. 55 A). Há ocorrência de 14 gêneros e 23 espécies, sendo todos os indivíduos representantes da subordem Rotaliina (Fig. 55 B e C). Já o ponto controle 2 apresenta densidade superior, sendo constituído por 3008 indivíduos $10 \mathrm{cc}^{-1}$ (Fig. 55 A). Essa estação é representada por 20 gêneros e 27 espécies, sendo a maioria (97,3\%) pertencente à subordem Rotaliina, e o restante à subordem Textulariina (Fig. 55 B, C e E). Não há ocorrência de miliolídeos (Fig. $55 \mathrm{D})$.

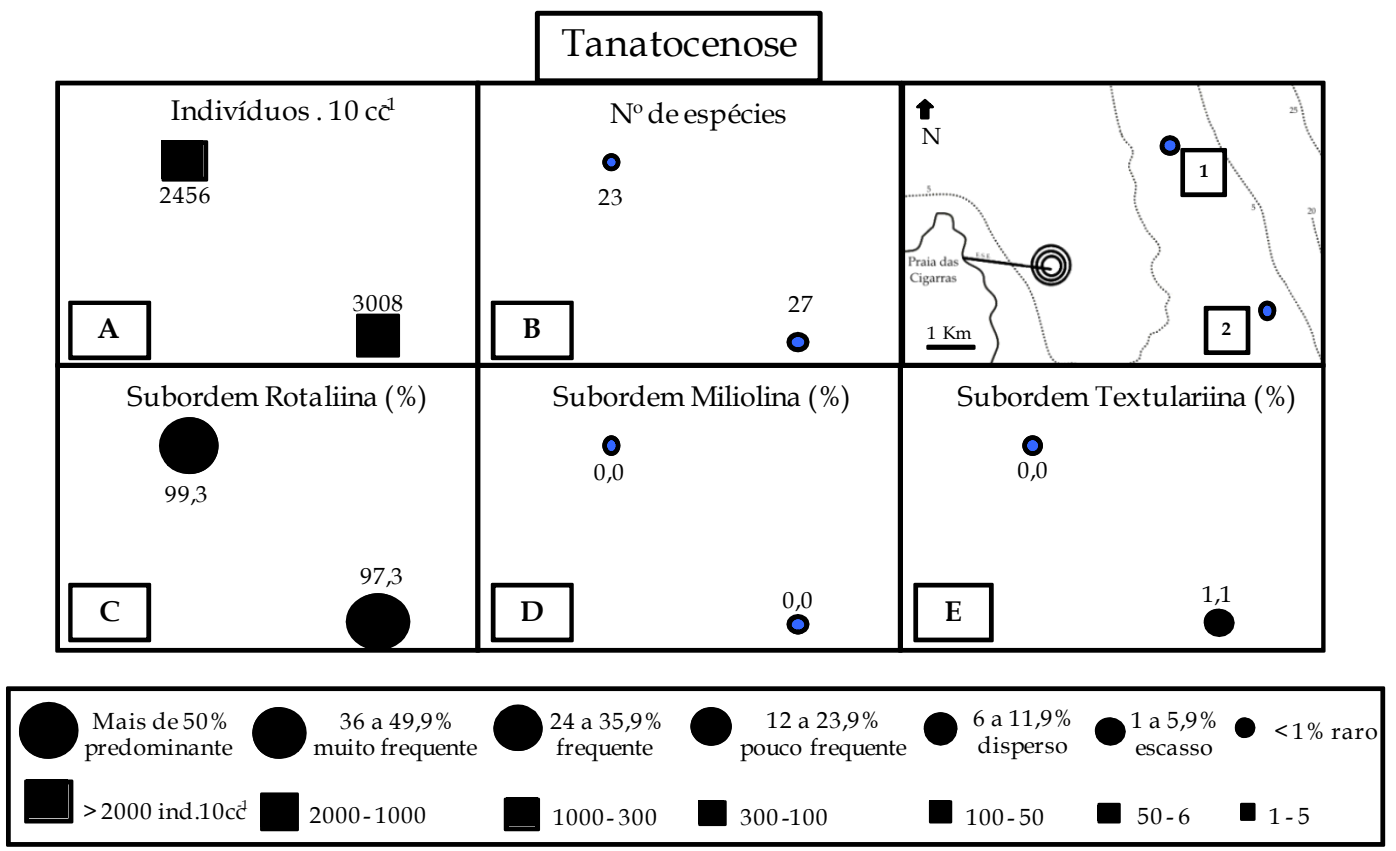

Figura 55: A: densidade, B: riqueza. Frequência relativa das principais subordens de foraminíferos $(\mathrm{C}, \mathrm{D}$ e $\mathrm{E})$ dos pontos controles. E.S.E.= emissário submarino de esgoto das Cigarras.

A espécie Pararotalia cananeiaensis (32,9\%) e os gêneros Ammonia (23,1\%), Cribroelphidium (14,7\%), Bulimina (6,8\%) e Bolivina (5,2\%) perfazem mais de $82 \%$ da amostra 1. Entre esses gêneros, as espécies que ocorrem com maior frequência são: $P$. cananeiaensis $(32,9 \%)$, A. tepida $(12,4 \%)$, A. parkinsoniana $(6,5 \%)$, C. poyeanum (3,6\%), B. marginata (5,5\%) e B. pulchella (2,0\%). Já no ponto 2, a espécie P. cananeiaensis $(35,1 \%)$ e os gêneros Ammonia (26,3\%), Cribroelphidium (10,4\%), Bolivina (6,6\%) e Bulimina (6,4\%) perfazem mais de $84 \%$ da amostra. As espécies que ocorrem com maior frequência são: $P$. cananeiaensis $(35,1 \%)$, A. tepida $(16,5 \%)$, A. parkinsoniana $(6,4 \%)$, C. poyeanum $(2,7 \%), B$. marginata $(4,8 \%)$ e B. pulchella $(3,2 \%)$. 
De acordo com o índice de diversidade, o controle 1 é mais diversificado $\left(\mathrm{H}^{\prime}=2,63\right)$, que o controle $2\left(\mathrm{H}^{\prime}=2,58\right)$ e apresenta espécies mais bem distribuídas entre seus indivíduos $\left(\mathrm{E}_{\mathrm{H}^{\prime}}=0,84\right)$.

A análise morfométrica revela predomínio de carapaças pequenas, que perfazem perfazendo $73 \%$ das tecas do controle 1 e 59\% das testas do controle 2 (Fig. 56). Carapaças médias também estão presentes e perfazem 26\% (ctle 1) a 41\% (ctle 2) dos indivíduos. Testas grandes ocorrem apenas no controle 1 e em pequena quantidade (1\%).

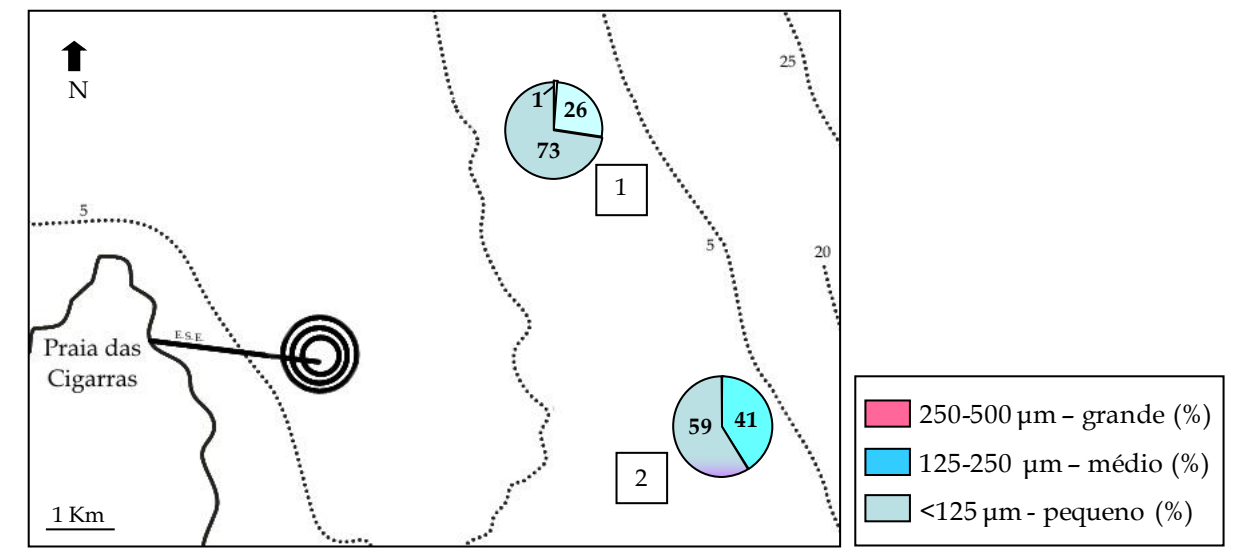

Figura 56: Morfometria das carapaças da tanatocenose dos pontos controles. E.S.E.= emissário submarino de esgoto das Cigarras.

A análise tafonômica revela predomínio de carapaças inteiras, sendo mais significativas no controle 2, onde perfazem 64\% das tecas (Fig. 57). Já o controle 1 possui $50 \%$ de testas inteiras e $49 \%$ de parcialmente fragmentadas. Fragmentos estão presentes em ambos os pontos, porém com pequenas contribuições (1\%).

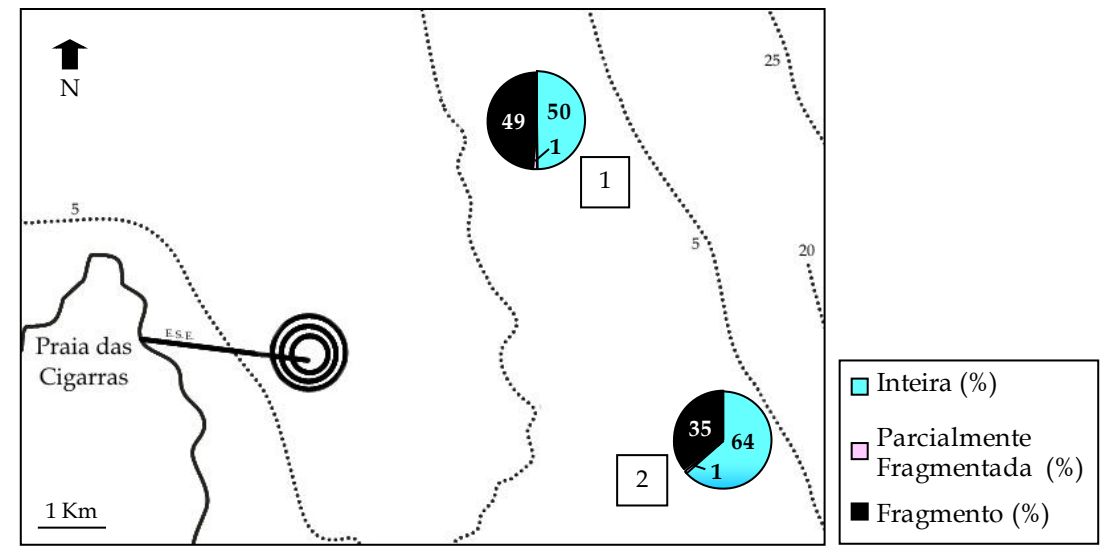

Figura 57: Análise tafonômica das carapaças da tanatocenose dos pontos controles. E.S.E.= emissário submarino de esgoto das Cigarras. 
As carapaças de coloração normal são majoritárias, representando 90\% das tecas no controle 1 e 97\% no controle 2 (Fig. 58). O controle 1 também apresenta representantes limonitizados (1\%), com monossulfeto de ferro (2\%) e piritizados $(7 \%)$. Testas limonitizadas estão ausentes no controle 2, mas piritizadas (1\%) e com monossulfeto de ferro $(2 \%)$ ocorrem em pequenas quantidades.

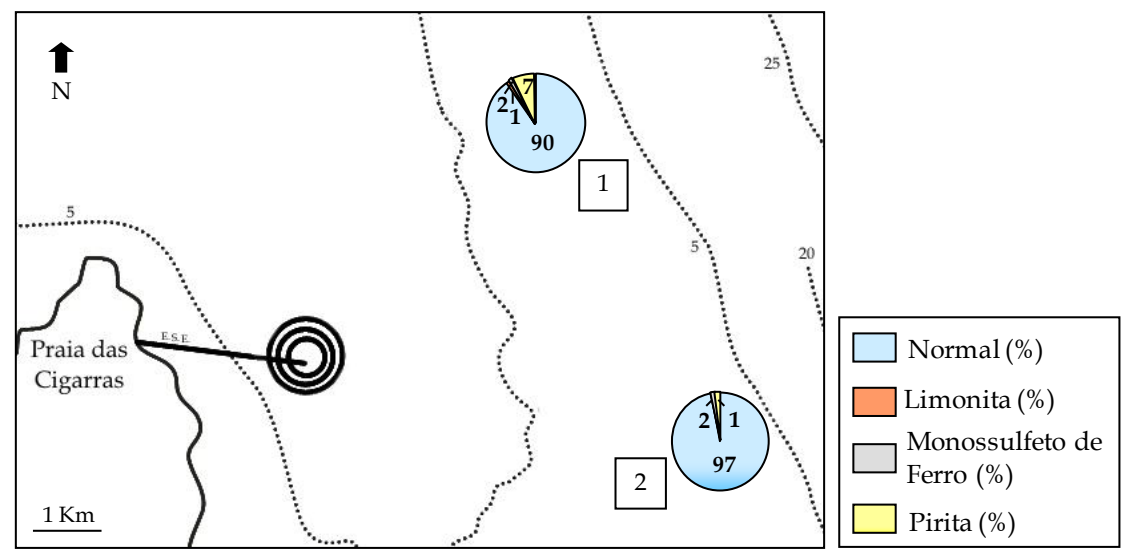

Figura 58: Coloração das carapaças da tanatocenose dos pontos controles. E.S.E.= emissário submarino de esgoto das Cigarras.

Indicadores de ambiente rico em matéria orgânica e oxigênio estão presentes em ambos os pontos, ocorrendo de forma acessória e rara, respectivamente. Seus representantes encontram-se listados na tabela 16. 
Tabela 16. Frequência relativa dos gêneros e espécies indicadoras de matéria orgânica e oxigênio dos pontos controles.

\begin{tabular}{|c|c|c|c|}
\hline & $\begin{array}{c}\text { Estação } \\
M=\text { morto }\end{array}$ & $\begin{array}{c}1 \\
\% \mathrm{M} \\
\end{array}$ & $\begin{array}{c}2 \\
\% M \\
\end{array}$ \\
\hline \multirow{18}{*}{ 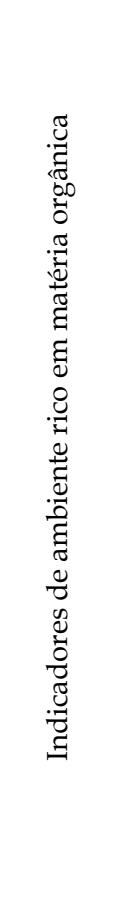 } & Bolivina compacta & 0,0 & 0,3 \\
\hline & Bolivina danvillensis & 1,0 & 0,8 \\
\hline & Bolivina doniezi & 1,3 & 1,1 \\
\hline & Bolivina ordinaria & 0,7 & 0,8 \\
\hline & Bolivina pulchella & 2,0 & 3,2 \\
\hline & Bolivina sp. & 0,3 & 0,5 \\
\hline & Buccella peruviana & 0,0 & 1,1 \\
\hline & Bulimina marginata & 5,5 & 4,8 \\
\hline & Bulimina pupoides & 1,0 & 0,8 \\
\hline & Bulimina sp. & 0,3 & 0,8 \\
\hline & Buliminella elegantissima & 3,9 & 1,6 \\
\hline & Brizalina striatula & 2,0 & 1,6 \\
\hline & Cassidulina minuta & 1,6 & 1,6 \\
\hline & Cassidulina sp. & 0,3 & 0,8 \\
\hline & Hopkinsina pacifica & 0,7 & 0,3 \\
\hline & Pseudononion atlanticum & 4,2 & 1,3 \\
\hline & Pseudononion sp. & 0,3 & 0,3 \\
\hline & Total & 25,1 & 21,5 \\
\hline \multirow{3}{*}{ 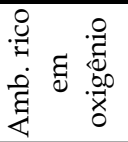 } & Discorbis williamsoni & 1,3 & 1,1 \\
\hline & Hanzawaia bouena & 0,7 & 0,8 \\
\hline & Total & 2,0 & 1,9 \\
\hline
\end{tabular}

Os indicadores totais de matéria orgânica do controle 1 estão representados por 7 gêneros e 11 espécies (Fig. 59 A). Há 4 principais grupos, sendo eles: Bulimina spp. (6,8\%), Bolivina spp. (5,2\%), Pseudononion spp. (4,6\%) e B. elegantissima (3,9\%) (Fig. 59 B, C, D, E e $\mathrm{F})$.

Apesar do controle 2 possuir 1 gênero e 2 espécies a mais que o controle 1, sua contribuição desses indicadores é menor (Fig. 59 A). Há 3 grupos mais representativos: Bolivina spp. (6,6\%), Bulimina spp. (6,4\%) e Cassidulina spp. (2,4\%) (Fig. 59 B, C, D, E e F). Da mesma maneira que o controle 1, a espécie mais representativa é a Bulimina marginata. 


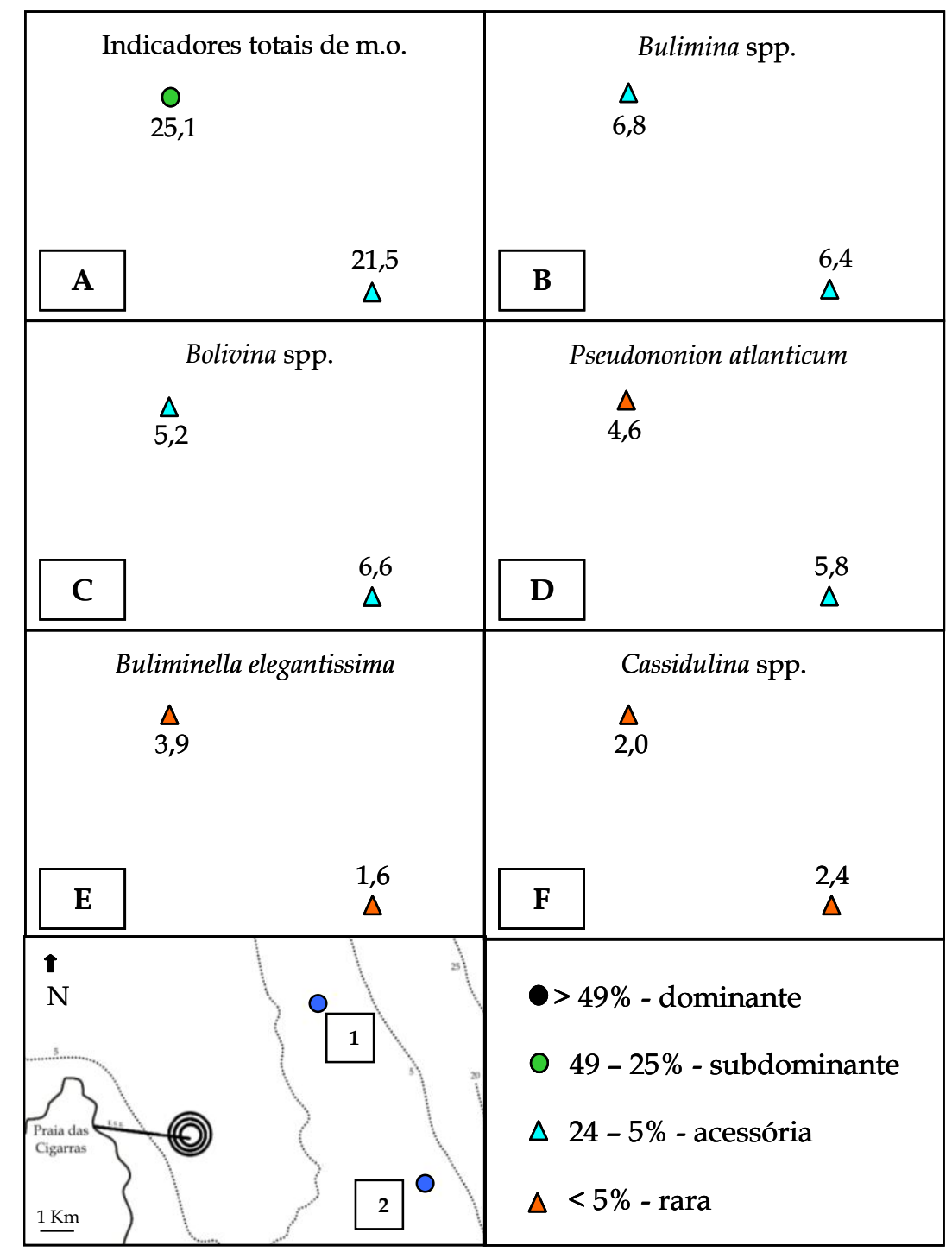

Figura 59: A: Frequência relativa total dos indicadores de matéria orgânico (m.o.). B, C, D, E e F: principais representantes de m.o. dos pontos controles. E.S.E.= emissário submarino de esgoto das Cigarras.

Indicadores de oxigênio ocorrem em pequenas porcentagens em ambas as estações, sendo representados apenas pelas espécies Discorbis williamsoni e Hanzawaia boueana (Fig. $60 \mathrm{~A}, \mathrm{~B}, \mathrm{C})$. 


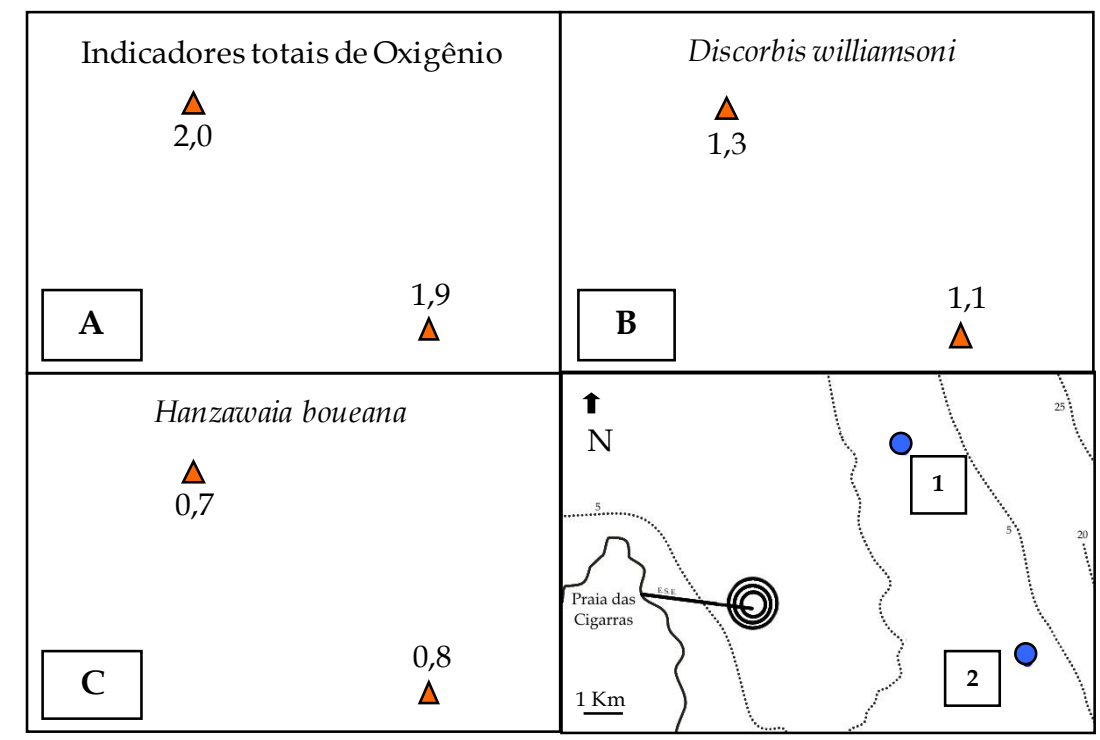

- $>49 \%$ - dominante $\bigcirc 49-25 \%$ - subdominante $\Delta 24-5 \%$ - acessória $\Delta<5 \%$ - rara

Figura 60: Frequência relativa total dos indicadores de ambiente rico em oxigênio. $B$ e C: principais representantes de oxigênio dos pontos controles. E.S.E.= emissário submarino de esgoto das Cigarras.

\subsection{3.b Comparação com as tanatocenoses de 2006 e 2007}

Os pontos controles apresentam as maiores densidades da área de estudo, sendo que o controle 2 o mais denso (3008 indivíduos $10 \mathrm{cc}^{-1}$ ) entre todas as amostras analisadas. Esse ponto possui praticamente o dobro da maior densidade encontrada em 2006. Da mesma maneira, os controles apresentam densidades superiores significativas ao período de 2007.

O ponto controle 2, que está mais afastado da área do emissário submarino de esgoto, além de possuir maior densidade, também apresenta maior número de gêneros e espécies (riqueza) que o controle 1 e que todas as estações dos anos anteriores, com exceção da estação 2 no ano de 2007. Já o controle 1 é mais rico que todos os pontos de 2006 e que 6 estações de 2007.

Essas diferenças entre a abundância e riqueza dos pontos controles com os demais também são constatadas pelo cálculo estatístico ANOVA (Fig. 61). De acordo com os resultados, os anos de 2006 e 2007 são semelhantes entre si, porém divergem dos pontos 
controles, sendo que a diferença é significativa entre 2006 e os controles $(p<0,05)$, e extremamente significativa entre 2007 e os controles $(p<0,01)$.

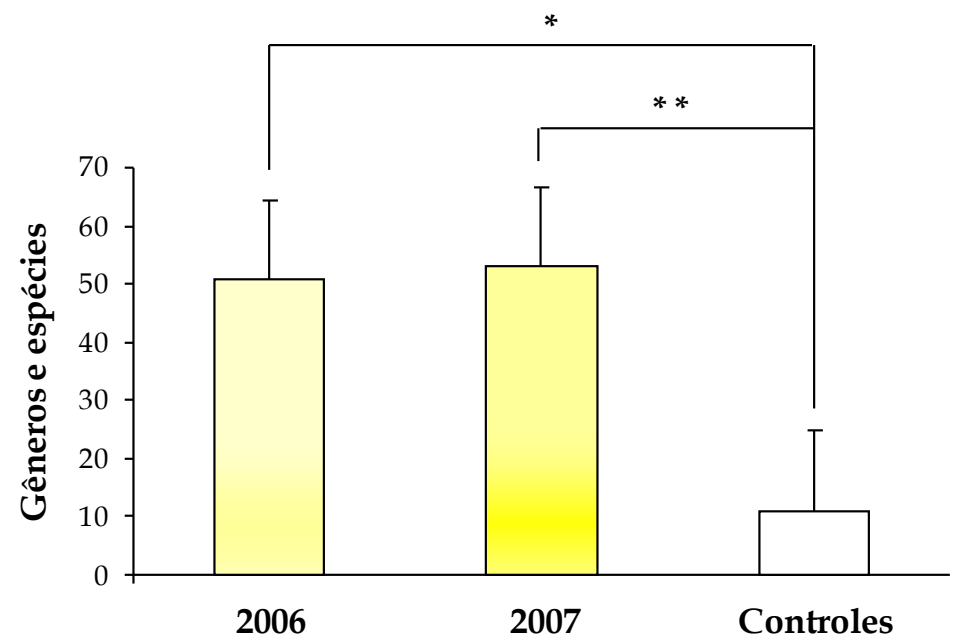

Figura 61: Relação entre a média do número gêneros e espécies, e seu respectivo desvio-padrão, das tanatocenoses de 2006, 2007 e pontos controles. Um asterisco $\left(^{*}\right)$ indica que $p<0,05$ e dois asteriscos $(* *)$ indica que $\mathrm{p}<0,01$.

Nos controles, a espécie predominante é a $P$. cananeiaensis, seguida pela A. tepida e A. parkinsoniana. Já nas demais estações, a espécie predominante é a A. tepida, seguida de Pararotalia cananeiaensis e A. parkinsoniana. Nos 2 anos e nos controles, os principais gêneros são Pararotalia, Ammonia e Cribroelphidium (Fig. 62). Todos os pontos apresentam contribuições inferiores de bolivinas e buliminas.

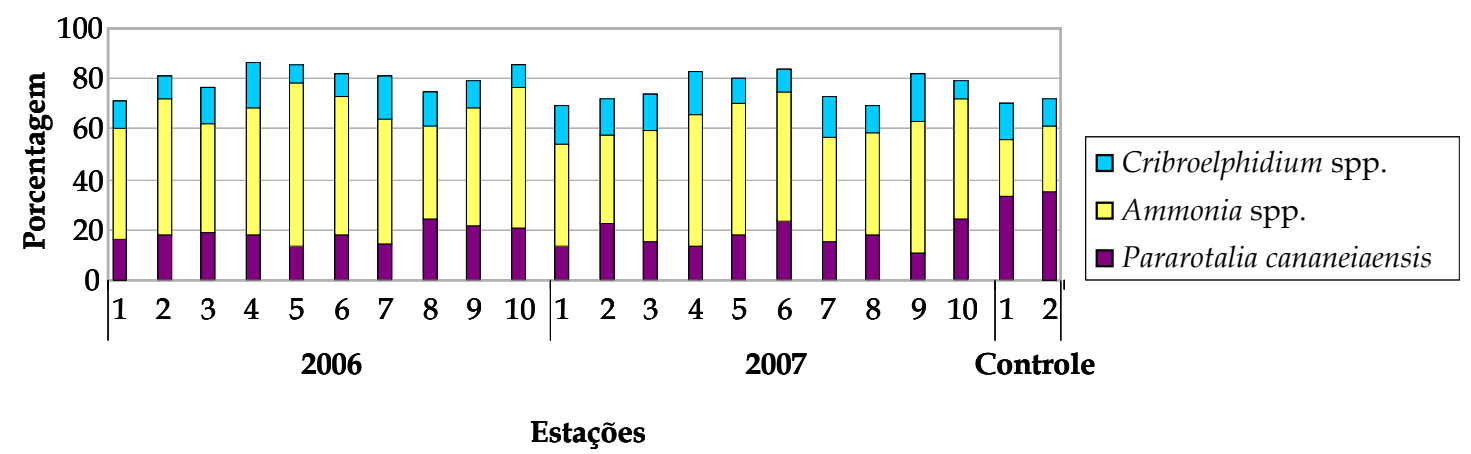

Figura 62: Principais foraminíferos constituintes das tanatocenoses do estudo. 


\subsection{3.c Biocenose}

As frequências relativas dos gêneros e espécies encontrados nos pontos controles, assim como seus índices de diversidade de Shannon $\left(\mathrm{H}^{\prime}\right)$ e equitatividades $\left(\mathrm{E}_{\mathrm{H}^{\prime}}\right)$ estão listadas no Anexo 07.

O controle 1 apresenta densidade de 74 indivíduos $10 \mathrm{cc}^{-1}$ distribuídos em 10 gêneros e 12 espécies (Fig. 63 A, B). A subordem Rotaliina é predominante, perfazendo mais de 97 \% dos indivíduos, sendo o restante pertencente à subordem Textulariina (Fig. 63 C, D, E). O controle 2 é mais abundante que o controle 1, já que possui densidade de 104 indivíduos 10 cc $^{-1}$ (Fig. 63 A). Há ocorrência de 12 gêneros e 13 espécies (Fig. 63 B). Seus representantes são majoritariamente rotalíneos $(98,1 \%)$ seguidos de textularíneos $(1,9 \%)$ (Fig. 63 C, E). Da mesma maneira que o controle 1, representantes da subordem Miliolina estão ausentes (Fig 63 D).

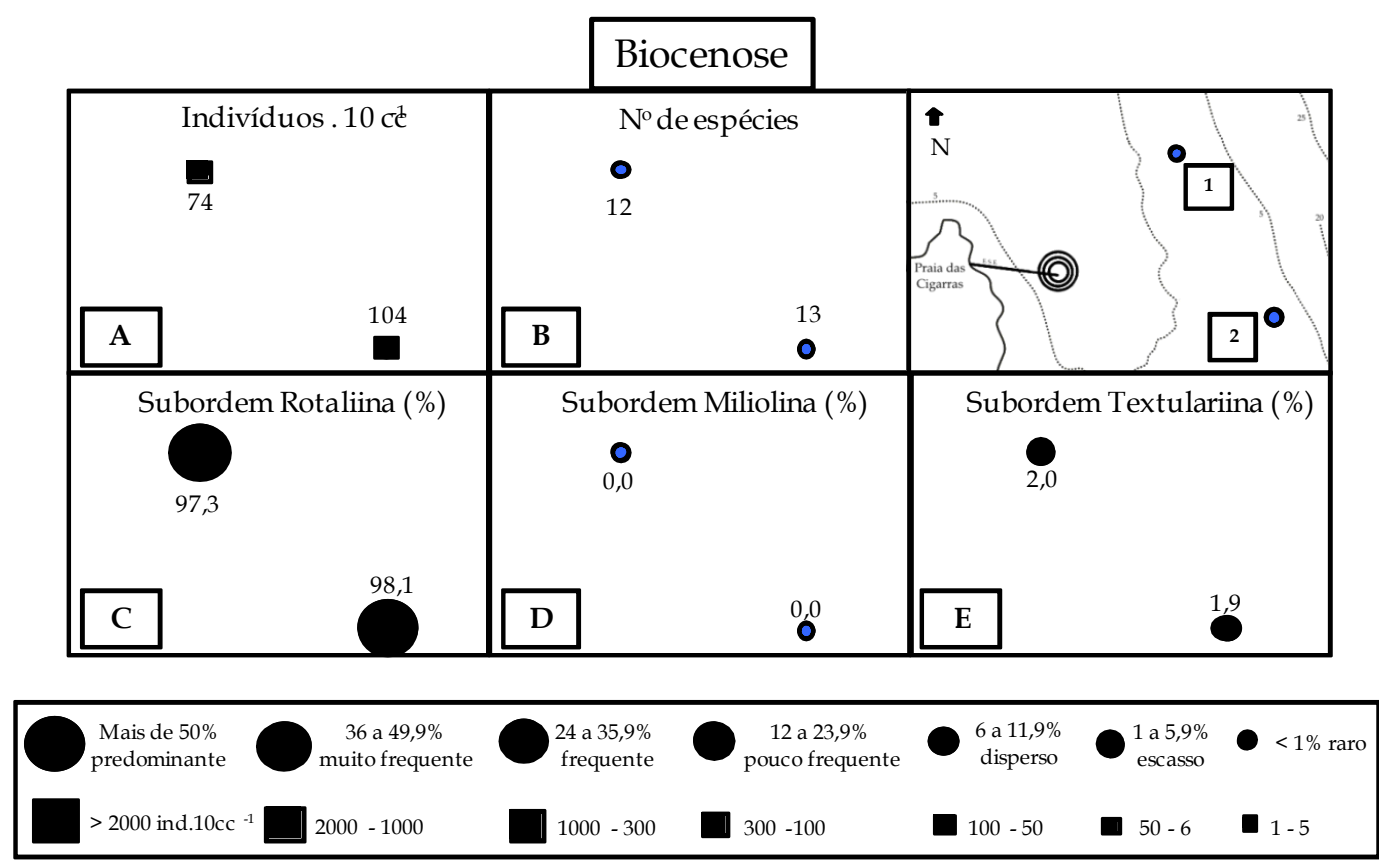

Figura 63: A: densidade, B: riqueza. Frequência relativa das principais subordens de foraminíferos (C, D e E) dos pontos controles. E.S.E.= emissário submarino de esgoto das Cigarras.

O gênero Ammonia perfaz 81,8\% do controle 1, sendo a espécie de maior ocorrência a A. tepida (56,1\%), seguida da A. parkinsoniana (19,6\%), Bolivina doniezi (2,7\%) e Buliminella 
elegantissima (2,7\%). Da mesma maneira, o controle 2 é representado principalmente pelo gênero Ammonia (61,5 \% dos foraminíferos), sendo a principal espécie a A. tepida (39,4\%), seguida da A. parkinsoniana (17,3\%) e Brizalina striatula $(7,7 \%)$. Representantes dos grupos Bolivina spp., Pseudononion spp. e Cribroelphidium spp. também estão presentes.

De acordo com o índice de diversidade de Shannon, o controle 2 é mais diversificado $\left(\mathrm{H}^{\prime}=2,14\right)$ que o controle $1\left(\mathrm{H}^{\prime}=1,62\right)$, e também é representado por espécies mais bem distribuídas entre seus indivíduos $\left(\mathrm{E}_{\mathrm{H}^{\prime}}=0,86\right)$.

De acordo com a análise morfométrica, as carapaças pequenas constituem a maioria, apresentando contribuições entre 58\% (\#2) e 65\% (\#1) (Fig. 64). As testas médias perfazem de $34(\# 1)$ a $42 \%$ (\#2) dos indivíduos enquanto que tecas grandes são encontradas apenas no controle 1 e em pequenas quantidades (1\%).

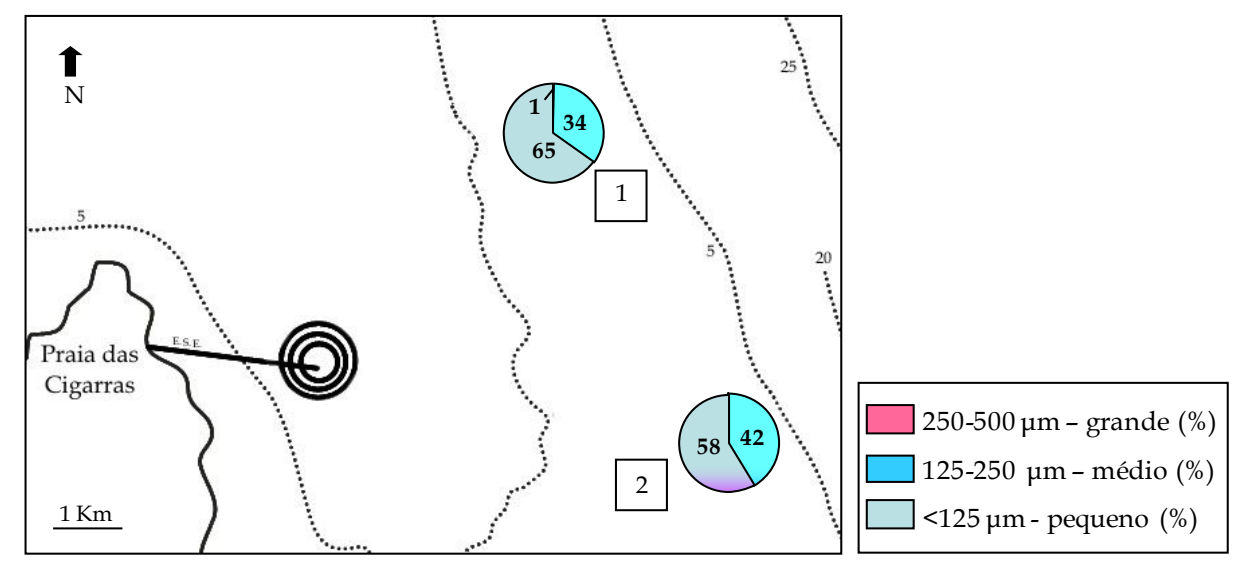

Figura 64: Morfometria das carapaças da biocenose dos pontos controles. E.S.E.= emissário submarino de esgoto das Cigarras.

Carapaças inteiras são predominantes e constituem 58\% das carapaças do controle 1 e 66\% do controle 2 (Fig. 65). Carapaças parcialmente fragmentadas têm maior ocorrência no 1 (42\%) do que no 2 (33\%), e fragmentos estão presentes apenas no 2, porém em quantidades pequenas $(1 \%)$. 


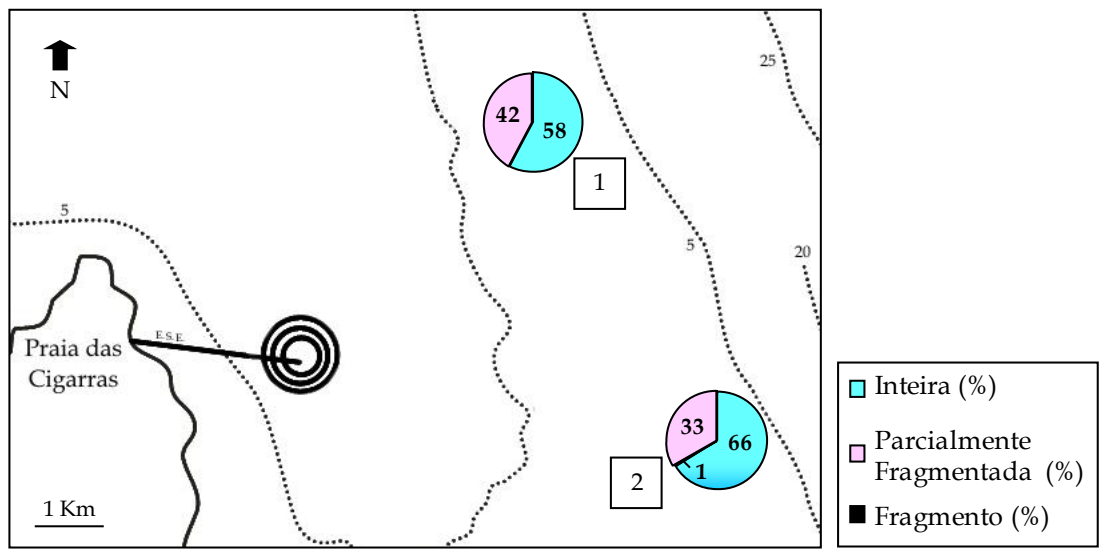

Figura 65: Análise morfológica das carapaças da biocenose dos pontos controles. E.S.E.= emissário submarino de esgoto das Cigarras.

Em ambos os pontos controles há apenas representantes de ambiente rico em matéria orgânica que ocorrem de forma acessória. Esses indicadores encontram-se listados na tabela 17.

Tabela 17. Indicadores de ambiente rico em matéria orgânica (m.o.) dos pontos controles.

\begin{tabular}{|c|c|c|c|}
\hline & $\begin{array}{l}\text { Estação } \\
V=\text { vivo }\end{array}$ & $\begin{array}{c}1 \\
\% \mathrm{~V}\end{array}$ & $\begin{array}{c}2 \\
\% V\end{array}$ \\
\hline \multirow{2}{*}{ 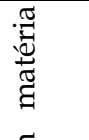 } & Ammoscalaria sp. & 0,7 & 1,9 \\
\hline & Bolivina compacta & 0,7 & 1,9 \\
\hline \multirow{5}{*}{ 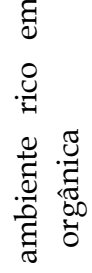 } & Bolivina danvillensis & 0,7 & 0,0 \\
\hline & Bolivina doniezi & 2,7 & 1,0 \\
\hline & Bolivina ordinaria & 0,0 & 1,0 \\
\hline & Bolivina sp. & 1,4 & 1,9 \\
\hline & Buliminella elegantissima & 2,7 & 6,7 \\
\hline \multirow{2}{*}{ ฮั } & Brizalina striatula & 2,0 & 7,7 \\
\hline & Cassidulina sp. & 0,7 & 0,0 \\
\hline \multirow{3}{*}{ 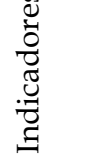 } & Pseudononion atlanticum & 2,0 & 5,8 \\
\hline & Uvigerina peregrina & 0,0 & 1,0 \\
\hline & Total & 13,5 & 28,8 \\
\hline
\end{tabular}

Os indicadores totais de matéria orgânica ocorrem de forma acessória em ambos os pontos, porém no 2 eles são mais representativos (Fig. $66 \mathrm{~A}$ ). O controle 1 é representado por 6 gêneros e 7 espécies. Há quatro principais grupos que perfazem 89,6\% desses indicadores, sendo eles: Bolivina spp. (40\%), B. elegantissima (20\%), B. striatula (14,8\%) e 
Pseudononion spp. (14,8\%) (Fig. 66 B, C, D e E). As espécies de maior frequência são a $B$. doniezi e B. elegantissima.

Da mesma maneira, o controle 2 é constituído pelo mesmo número de gêneros e espécies, porém apresenta maior quantidade de indicadores. Há quatro principais grupos que perfazem 90,2 \% dos indicadores, sendo eles: B. striatula (26,7\%), B. elegantissima (23,3\%), Bolivina spp. (20,1\%) e P. atlanticum (20,1\%) (Fig. 66 B, C, D e E). A B. striatula é a espécie de maior representatividade. Verifica-se que os 4 principais grupos são os mesmos em ambos pontos controles com diferenças nas porcentagens de contribuição entre eles.

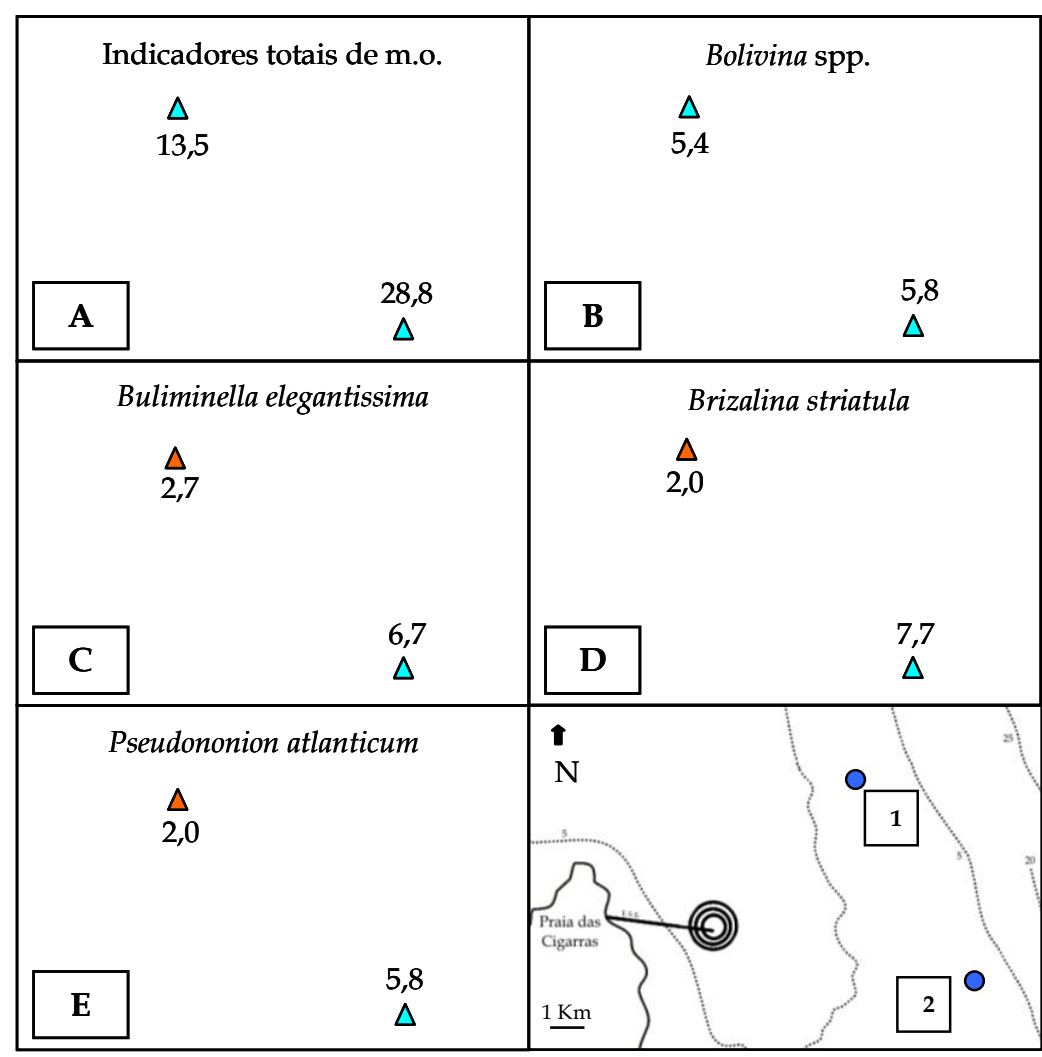

$>49 \%$ - dominante $\bigcirc 49-25 \%$ - subdominante $\Delta 24-5 \%$ - acessória $\Delta<5 \%$ - rara

Figura 66: Frequência relativa total dos indicadores de matéria orgânico (m.o.). B, C, D e E: principais representantes de m.o. dos pontos controles. E.S.E.= emissário submarino de esgoto das Cigarras. 


\subsection{3.d Comparação da biocenose controle com a tanatocenose controle}

O controle 2 apresenta maior densidade e riqueza que o 1 tanto nos foraminíferos vivos quanto nos mortos. As tanatocenoses apresentam densidades superiores a 27 vezes as obtidas nas biocenoses, além de também serem mais ricas (13 espécies a mais). Há o predomínio de $P$. cananeiaensis na tanatocenose e de $A$. tepida na biocenose.

Esses dados corroboram com os resultados obtidos no Teste Kruskal Wallis, já que há diferenças extremamente significativas $(\mathrm{p}<0,01)$ entre os mortos e os vivos (Fig. 67).

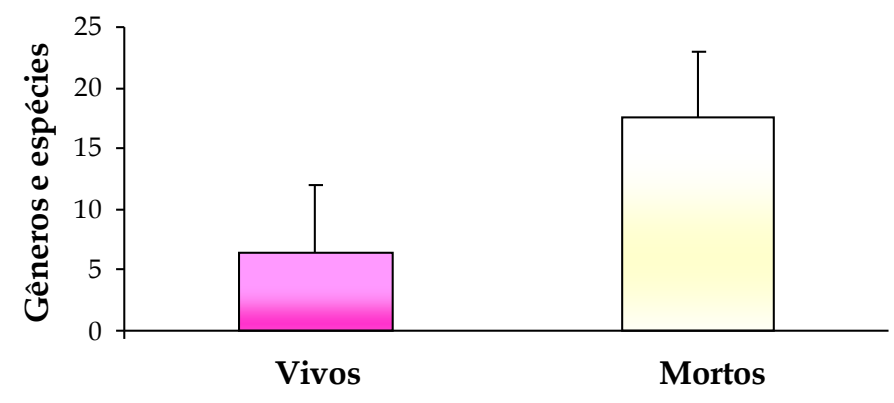

Figura 67: Relação entre a média do número de gêneros e espécies, e seu respectivo desviopadrão, da tanatocenose e biocenoses dos pontos controles.

\subsection{3.e Comparação da biocenose controle com as biocenoses de 2006 e de 2007}

Em 2006, a densidade mínima é de 65 e a máxima é de 215 indivíduos 10 cc $^{-1}$. O controle 1 possui densidade de 74 indivíduos $10 \mathrm{cc}^{-1}$, sendo portanto mais abundantes apenas que os pontos 2 e 9 de 2006. Já o controle 2, que é mais denso que o 1, apresenta densidade de 104 indivíduos $10 \mathrm{cc}^{-1}$, sendo menos abundante apenas que os pontos 1, 4, 6 e 10 de 2006.

Já o ano de 2007 possui densidade mínima de 85 e máxima de 250 indivíduos 10 cc1. O controle 1 é menos denso do que todos os pontos amostrais de 2007. Já o controle 2 é mais abundante apenas que os pontos 1, 6, e 10 de 2007.

Apenas as estações 4 e 7 de 2006 e 2 e 7 de 2007 são mais ricas que os controles, porém o 1 apresenta uma espécie a mais que o 2. 
Essas diferenças entre a abundância e riqueza dos pontos controles com os demais também são constatadas pelo cálculo estatístico ANOVA (Fig. 68). De acordo com os resultados, os anos de 2006 e 2007 são semelhantes entre si, porém ambos divergem dos controles de maneira significativa $(p<0,05)$.

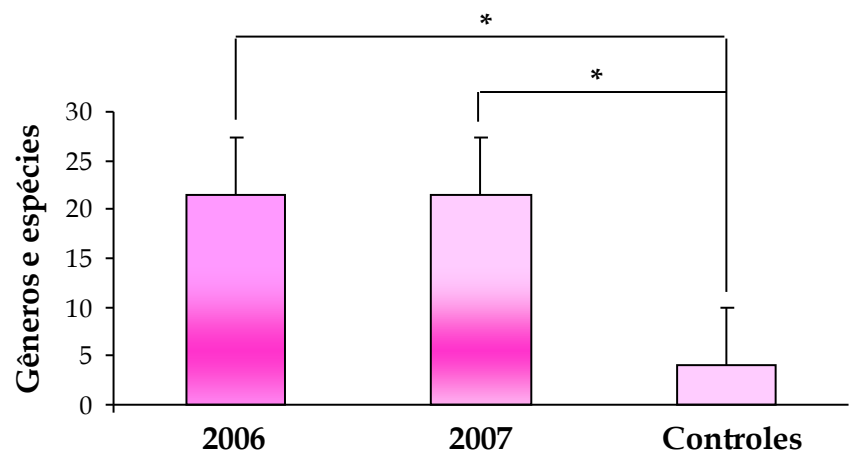

Figura 68: Relação entre a média do número de gêneros e espécies, e seu respectivo desviopadrão, das biocenoses de 2006, 2007 e pontos controles. Um asterisco $\left(^{*}\right)$ indica que $p<0,05$.

Em todos os pontos amostrais, o gênero dominante é o Ammonia. Em 2006, ele apresenta frequência relativa que varia entre 72,4 e $89,5 \%$. Em 2007, sua frequência oscila de 64,8 a 81,2\%. Já no controles os valores são 61,5 (2) e 81,8\% (1). Assim, observa-se que o ano de 2006 possui maior contribuição desse gênero. A A. tepida é principal espécie de todas as estações, sendo seguida pela A. parkinsoniana. No ano de 2006, 2007 e controle 2, a terceira espécie mais significativa é a $B$. striatula, enquanto que no controle 1 são as $B$. doniezi e B. elegantissima. Dessa maneira, verifica-se que nos três anos do estudo, os principais gêneros presentes são Ammonia, Bolivina e a espécie B. striatula (Fig. 69).

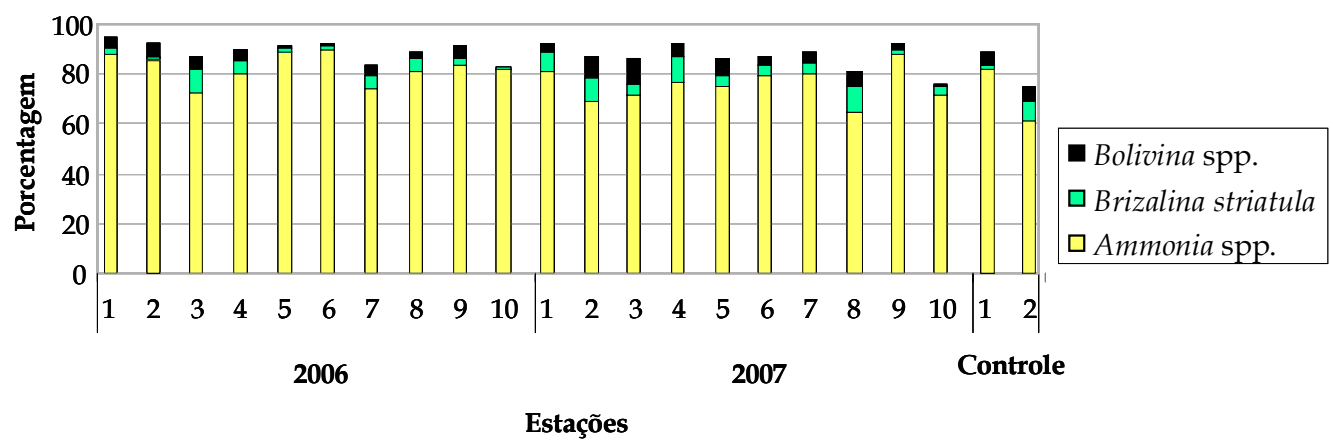

Figura 69: Principais gêneros e espécie presentes nos pontos amostrais em 2006, 2007 e pontos controles. 


\section{DISCUSSÃO}

\subsection{Parâmetros hidrográficos e hidroquímicos}

De acordo com os dados hidrográficos, verifica-se homogeneidade salina e térmica na área de estudo ao longo da coluna da d'água. Em todas as estações (com exceção da 1 em 2007), o pH decai suavemente da superfície em direção ao fundo, sem apresentar grandes oscilações.

O ano de 2006 apresenta elevados valores de turbidez quando comparado com 2007. Isso pode estar relacionado a um maior fluxo de aporte do efluente em 2006, que acarretou em maior quantidade de material em suspensão, proveniente da pluma de esgoto na região. Nos dois anos de amostragem, os maiores valores de turbidez localizamse preferencialmente no fundo da coluna d’água. Em 2006, há estações que apresentam maiores valores na superfície, indicando a elevação da pluma de esgoto.

Há grande variação nos teores de OD entre 2006 e 2007. Em 2006, as estações apresentam teores de OD abaixo do exigido pelo CONAMA, com exceção dos pontos 5 e 9. Isso talvez seja explicado pelo aumento no aporte de matéria orgânica na área, que além de causar altos valores de turbidez, acarretou em grande consumo de oxigênio para seu processo de decomposição. Como a maior parte dessas reações ocorre próxima e no sedimento, verifica-se que em todas as estações, com exceção do ponto 4, há decréscimo da concentração de oxigênio da superfície em direção ao fundo. A alta turbidez da coluna d'água também pode ter influenciado negativamente o processo de fotossíntese, diminuindo a disponibilidade de oxigênio dissolvido no meio. Já em 2007, todos os valores de OD apresentam-se dentro do estabelecido pela legislação. Isso pode ser explicado devido a uma maior circulação local que proporcionou melhor oxigenação das águas da região, quanto na redução do volume de efluente disposto no mar, ocasionando baixos valores de turbidez, e consequentemente decréscimos no consumo de oxigênio.

Amostras de água coletadas pela CETESB em julho de 2005 (CETESB, 2007), nos mesmos pontos amostrais do presente estudo, apresentam valores de $\mathrm{pH}$ e OD semelhantes dos obtidos em 2007. Tais resultados permitem inferir que a quantidade de efluente presente no momento da coleta foi maior em 2006 que em 2005 e 2007. 


\subsection{Parâmetros Granulométricos}

De acordo com as análises granulométricas, os pontos estudados são constituídos por sedimentos arenolamosos, principalmente por areia síltica (Shepard, 1954). Na malha amostral ao redor do emissário há predomínio da fração silte, enquanto que nos pontos controles a fração areia muito fina é majoritária. Segundo Pereira e Gomes-Soares (2002), o tamanho médio das partículas de uma região está diretamente relacionado com seu grau de exposição hidrodinâmica. Assim, pode-se dizer que a energia de fundo da região do estudo varia de fraca a moderada.

As maiores porcentagens de areia ocorrem nos pontos localizados na saída dos difusores e a $100 \mathrm{~m}$ ao sul dos mesmos. Isso ocorre provavelmente pela maior hidrodinâmica local gerada pela descarga do efluente. Já os maiores teores de lama encontram-se a oeste dos difusores.

Segundo a classificação de Folk e Ward (1957), os sedimentos oscilam entre muito pobremente a pobremente selecionados, indicando que a corrente de fundo da região estudada não age de modo constante e nem com mesma intensidade.

Estudos realizados em 2005, na mesma malha amostral das Cigarras, revelam pequenas alterações na classificação granulométrica das estações de um ano para outro (Teodoro et al., 2009). Da mesma maneira que os períodos do presente estudo, em 2005 há predomínio de areia síltica, e de sedimentos muito pobremente selecionados (Teodoro et al., 2009). O padrão de distribuição das diferentes frações granulométricas é semelhante entre os três anos consecutivos (2005, 2006 e 2007), sendo que as maiores quantidades da fração areia localizam-se próximas à desembocadura do emissário.

\subsection{Parâmetros Geoquímicos}

A partir dos dados de carbonato de cálcio, constata-se que a região é constituída por sedimentos essencialmente litoclásticos, tendo maior contribuição em 2007. Os valores encontrados estão de acordo com os dados obtidos por Teodoro et al. (2009) na mesma área, bem como na área ao redor do emissário do Saco da Capela (Teodoro et al., 2010) e em outras regiões adjacentes à área de estudo (Furtado et al., 1998). 
Em 2006 e em 2007, os maiores teores de enxofre, nitrogênio e carbono localizam-se preferencialmente nas estações com maiores contribuições de sedimentos lamosos.

Os dados de carbono orgânico revelam que o ano de 2007 apresenta maiores quantidades desse elemento que de 2006 para 2007 há decréscimo em algumas estações (\# 1 a 5) e acréscimo nas demais (\# 6 a 10). Em 2006 as maiores porcentagens de carbono orgânico ocorrem na porção oeste da malha amostral, onde foram encontrados as maiores porcentagens de lama. Já em 2007, os maiores teores são encontrados na região noroeste, nordeste e sul. Segundo Furtado (1995), a corrente de fundo da praia das Cigarras é caracterizada por sua constante alternância de sentido e fluxo. Assim, a diferença na distribuição desse elemento químico pode estar relacionada com a circulação mais heterogênea da região.

Em ambos os anos, a estação 1, localizada na saída dos difusores, apresenta os menores teores de carbono orgânico, enquanto que os pontos amostrais que distam $300 \mathrm{~m}$ dos mesmos possuem as maiores porcentagens. Essa distribuição pode ser explicada pelo fato de que na saída dos difusores há maior hidrodinâmica, enquanto que nas áreas mais afastadas ela é menor, possibilitando então o acúmulo de matéria orgânica proveniente do efluente.

As menores porcentagens de carbono orgânico do estudo ocorrem nos pontos controles, sendo que o controle 2 possui o menor. De acordo com Barcellos e Furtado (1998), a maior parte dos detritos orgânicos terrígenos, carreados para os oceanos, é constituída de plantas superiores ricas em compostos de carbono - celulose e lignina. Assim, grandes quantidades de carbono orgânico indicam contribuição de matéria orgânica proveniente do continente. Dessa maneira, as menores porcentagens encontradas nos controles podem ser decorrentes da maior distância à saída dos difusores, já que a maior parte da matéria orgânica deposita-se na região mais próxima da disposição do efluente. Os teores de carbono orgânico nas Cigarras variam de 0,76 a 2,75\%.

Barcellos e Furtado (1998) analisaram conteúdo geoquímico dos sedimentos do Canal de São Sebastião. As análises de carbono orgânico revelam teores mínimos na porção sul continental $(0,1 \%)$, onde há ação direta das ondas, e máximos ao norte continental que apresenta baixa hidrodinâmica (2,5\%). Os teores obtidos ao longo do canal são considerados de intermediários a baixo quando comparados com outras áreas 
similares do globo, podendo estar relacionado com a ausência de drenagens fluviais significativas na região (Barcellos e Furtado, 1998) e a circulação local que não possibilita a preservação da matéria orgânica (Furtado et al., 1998). Estudo realizado na área circunjacente ao emissário do Araçá, São Sebastião, revela concentrações de Corg que variam de 0,10 a 3,37\% (Gubitoso et al., 2008). Já na área circunjacente ao emissário do Saco da Capela, os teores oscilam entre 0,15 a 2,27\% (Teodoro et al., 2010).

A Enseada do Guarujá apresenta baixos teores de carbono orgânico que variam de 0,10 a 1,31 durante o inverno de 1997, sendo o maior valor encontrado próximo ao emissário submarino de esgoto. Já a área circunjacente ao emissário de Santos (Abril de 2004) apresenta teores que oscilam de 0,13 a 2,00 (Teodoro, 2006).

Estudos na baía de Santos demonstram teores de carbono orgânico inferiores a 1\%, com exceção da estação localizada próxima à desembocadura do emissário submarino de esgoto $(1,38 \%)$ (Bonetti, 2000). Desta maneira, pode-se inferir que os teores de carbono orgânico nas Cigarras são valores intermediários.

As porcentagens de enxofre não apresentam variações espaciais significativas entre os anos, sendo as maiores porcentagens localizadas à oeste da desembocadura do emissário, e nas mesmas estações onde foram observados maiores teores de lama e de Corg. O controle 1 apresenta menores teores do que a maioria das estações de ambos os anos, com exceção dos pontos 1 (2006) e 4 e 7 (2007). Já o controle 2 possui as menores porcentagens do estudo. O padrão de distribuição do enxofre assemelha-se ao do carbono orgânico. Os menores teores de enxofre encontrados nos pontos controles podem ser explicados por sua maior distância dos difusores. Assim, há menor aporte e deposição de matéria orgânica e, consequentemente, menor degradação bacteriana da mesma.

Os teores de $S$ total obtidos nas Cigarras variam entre 0,19 e 0,56\%. Já a enseada do Guarujá apresenta teores de enxofre total que variam de 0,01 a 1,43 no inverno de 1997. Na região próxima ao emissário de Santos os valores encontrados oscilam entre 0,05 a 0,69 (Teodoro, 2006), enquanto que ao redor do emissário do Araçá, em São Sebastião, os teores oscilam entre 0,09 a 0,46\% (Gubitoso et al., 2008). Na região próxima ao emissário do Saco da Capela, as porcentagens de enxofre variam entre 0,003 a 0,163\% (Teodoro et al., 2010).

A razão C/S é utilizada para indicar a disponibilidade de oxigênio dos sedimentos, bem como a importância da redução biológica do sulfato na decomposição do carbono no 
sedimento e na coluna d’água (Cetecioğlu et al., 2009). Assim, ambientes redutores apresentam maiores teores de enxofre, proporcionando menor valor de C/S. Razões C/S superiores a 5 indicam que tanto a coluna d’água como os sedimentos possuem condições aeróbias, tendo o sedimento características oxidantes (Cetecioğlu et al., 2009). Sedimentos marinhos anaeróbios que são submetidos à redução do sulfato sob condições oxigenadas da coluna d’água apresentam razão C/S entre 1,5 e 5,0 (Hedge \& Keil, 1995). Já valores de C/S inferiores a 1,5 são característicos de ambiente com coluna d'água e sedimentos anóxicos (Berner, 1983; Hedge \& Keil, 1995). De acordo com Berner (1982) e Berner e Raiswell (1983), a média dessa razão nos sedimentos marinhos atuais é de 2,8 0 0,8.

Verifica-se que na região do estudo há predomínio de deposição em períodos de anoxia, apresentando, portanto características redutoras, já que a maioria dos pontos estudados possui razão C/S entre 1,5 e 5,0. Algumas estações, de cada ano, apresentam sedimentos e coluna d'água óxicos, estando posicionadas à uma maior distância da saída dos difusores. Os valores da razão C/S seguem o mesmo padrão dos teores de carbono. Dessa maneira, as razões diminuem de 2006 para 2007 nas estações 1 a 5 e aumentam nos pontos 6 a 9, permanecendo igual no ponto 10. De 2006 para 2007, as estações com caráter oxidante não são as mesmas talvez pela diferença na circulação da região entre os anos. Não há ocorrência de subambientes com sedimentos e coluna d'água anóxicos. O controle 1 é considerado óxico enquanto que o 2 possui características tendendo a redutoras.

No Guarujá, os valores dessa razão variam de 0,93 a 16,50, sendo a maioria dos pontos classificados como oxidantes. Em Santos, todas as estações apresentam características redutoras (C/S oscila entre 1,93 a 4,77) (Teodoro, 2006), assim como a maioria dos pontos do Araçá (C/S varia entre 1,1 a 19,9) (Gubitoso et al., 2008). Ambos os locais sofreram momentos anóxicos de deposição, corroborando com a maioria das estações das Cigarras.

Na maioria das estações ocorreu acréscimo nos teores de nitrogênio total de 2006 para 2007. Em 2006, esse elemento não apresenta um padrão de distribuição. Já em 2007, os menores valores são encontrados nos pontos centrais da malha amostral. As estações 7 e 9 que apresentam os menores valores de 2006 estão entre os pontos de maiores porcentagens no ano seguinte. Os valores encontrados nos controles estão entre os menores do estudo. Os teores de nitrogênio total nas Cigarras variam entre 0,13 a 0,56\%, 
sendo superiores aos valores obtidos em torno do emissário do Araçá (0,01 a 0,10\%) (Gubitoso et al., 2008) e do emissário do Saco da Capela (0,01 a 0,10\%) (Teodoro et al., 2010).

De acordo com a razão $\mathrm{C} / \mathrm{N}$, a origem da matéria orgânica da região é predominantemente marinha $(\mathrm{C} / \mathrm{N}<6)$, seguida pela origem mista $(\mathrm{C} / \mathrm{N}=6$ a 12$)$. As estações que apresentam origem marinha localizam-se ao redor da saída do emissário. É provável que sua distribuição esteja condicionada tanto a maior energia de fundo da região quanto pela constante alternância no sentido e fluxo das correntes de fundo das Cigarras (Furtado, 1995). Na região do emissário do Araçá há predomínio de origem continental (Gubitoso et al., 2008).

Em relação aos HPAs, dos 16 congêneres analisados, apenas o Benzo(b)fluoranteno, Fluoranteno, Naftaleno e Pireno apresentam valores acima do limite de quantificação do método, sendo restritos a algumas estações. O ano de 2006 apresenta mais HPAs quantificáveis que 2007, tendo em comum o Naftaleno. Ambos os anos revelam baixas concentrações de todos os congêneres e em todos os pontos amostrais. As concentrações encontradas estão abaixo dos ISQGs (limites de qualidade dos sedimentos), assim como do PEL (probable effect level) determinados pelo CCME (Canadian Council of Ministers of the Environment, 2002). De acordo com a concentração de HPAs encontrada em um estudo, os resultados podem ser classificados em três grupos distintos. Valores abaixo dos ISQGs estão raramente associados a efeitos adversos à biota. Valores entre os ISQGS e PEL podem estar ocasionalmente associados a efeitos adversos, enquanto que valores superiores ao PEL são frequentemente associados a efeitos adversos para a biota (Environment Canada,1998 apud CCME, 1999). Nos dois anos, as taxas de recuperação dos surrogates, utilizados durante as análises, estão dentro dos limites de controle de qualidade e apresentam valores próximos entre si.

Os HPAs podem ser classificados, de acordo com sua origem, em duas categorias: os pirogênicos, que são derivados da queima incompleta de combustíveis fósseis e biomassas; e os petrogênicos, que são provenientes do petróleo. Assim, HPAs constituídos por mais de 3 anéis benzênicos são pirogênicos, como o benzo(a)antraceno, benzo[a]pireno, benzo[e]pireno, benzo(b)fluoranteno, benzo(k)fluoranteno, benzo[ghi]perileno, criseno, dibenzo[ah]antraceno, fluoranteno, indeno[1,2,3cd)pirene e 
pireno (Barrick \& Prahl, 1987). Já os HPAs que possuem 3 ou menos anéis, são considerados petrogênicos, como o acenafteno, acenaftileno, fluoreno, naftaleno e fenantreno (Burgess et al., 2009). Assim, verifica-se a ocorrência de HPAs tanto de origem pirogênica quanto petrogênica na área de estudo.

Análises realizadas pela CESTESB em 2008, nos mesmos pontos utilizados como controle neste estudo, revelam que no ponto 1 há 17,2 $\mu \mathrm{g} / \mathrm{Kg}$ de benzo(a)pireno, 27,2 $\mu \mathrm{g} / \mathrm{Kg}$ de fluoranteno e $25 \mu \mathrm{g} / \mathrm{Kg}$ de pireno (CETESB, 2009). Já pela análise realizada neste trabalho, esses compostos possuem concentrações inferiores ao limite de detecção (< $0,5 \mu \mathrm{g} / \mathrm{Kg}$ ). Essa diferença se deve provavelmente a diferença no tempo para a realização das análises.

Devido a problemas técnicos no cromatógrafo, as amostras, que tinham sido secas visando suas análises imediatas, acabaram sendo guardadas por mais de seis meses. Já as amostras da CETESB foram prontamente analisadas. Isso pode ter interferido na quantidade de HPAs encontrados, já que são substâncias semi-voláteis. Assim, as baixas concentrações desses hidrocarbonetos na área de estudo podem ser decorrentes do processo de conservação das amostras e/ou da pequena possibilidade de acúmulo dessas substâncias na região, já que o sentido preferencial da corrente no canal de São Sebastião é próximo à Ilha Bela. Dessa maneira não é possível concluir se os HPAs da região de estudo estão impactando ou não a biota marinha local.

Estudos realizados por Medeiros e Bícego (2004) revelam a presença de HPAs ao longo do canal de São Sebastião. As maiores concentrações dessas substâncias são encontradas próximo ao TEBAR (DTCS - Dutos e Terminais do Centro-Sul), porto e emissário de esgoto do Araçá e ao sul do canal. No ponto amostral localizado próximo ao emissário das Cigarras, há contribuição dos 16 congêneres de HPAs, porém em pequenas quantidades que oscilam entre 3,7 a 37,9 ng. $\mathrm{g}^{-1}$.

Análises realizadas em 1994/1995 de amostras de sedimentos ao longo do Canal de São Sebastião mostram que a região central (porto, DTCS e emissário do Araçá) e a norte do canal apresentam indícios de contaminação de hidrocarbonetos de petróleo (Bícego et al., 2008). Durante esse período ocorreu um vazamento de petróleo próximo a Praia de Baraqueçaba. Estudos de amostras de água demonstraram que após 3 meses do derrame, os valores de hidrocarbonetos obtidos nas amostras eram normais. Já os sedimentos, 
mesmo após 7 meses do derrame, continuavam a apresentar altos teores desses compostos. Isso comprova a importância de se estudar os sedimentos marinhos, uma vez que se tornam depósitos para muitas substâncias que se encontravam suspensas na coluna d'água.

De uma maneira geral, os sedimentos do canal de São Sebastião apresentam baixas concentrações de hidrocarbonetos, sendo comparáveis a regiões onde a influência antrópica não é significativa (Bícego et al., 2008).

\subsection{Foraminíferos}

\subsubsection{Tanatocenose}

Comparando-se as associações dos foraminíferos mortos de 2006 e de 2007 com os pontos controles, verifica-se que os controles possuem as maiores densidades e riquezas, sendo o controle 2 o mais denso e rico dentre todas as estações. Esse ponto possui praticamente o dobro da maior densidade encontrada em 2006. Da mesma maneira, os controles apresentam densidades superiores significativas ao período de 2007.

Essas diferenças são confirmadas pelo teste estatístico ANOVA, onde observa-se ocorrência de diferença significativa entre 2006 e pontos controles $(p<0,05)$ e extremamente significativas entre 2007 e pontos controles $(p<0,01)$. Já entre 2006 e 2007 não há diferenças, mostrando que as tanatocenoses dos dois anos são semelhantes entre si.

O ano de 2007 possui 2 gêneros e 4 espécies a mais que 2006, além de ter maior riqueza e densidade em suas estações. O ponto amostral 1, logo na saída dos difusores, é o único em que ocorre redução de riqueza de 2006 para 2007. A menor riqueza nos dois anos ocorre no ponto 4.

De acordo com o índice de diversidade de Shannon $\left(\mathrm{H}^{\prime}\right)$, há aumento da diversidade de 2006 para 2007 nos pontos amostrais. Em 2006, a diversidade e a equitatividade oscilam entre 1,93 a 2,60 e 0,68 a 0,85, respectivamente. Já em 2007, a diversidade e a equitatividade oscilam entre 2,11 a 2,60 e 0,68 a 0,86, respectivamente. $\mathrm{O}$ ponto 8 possui a maior diversidade em 2006 e em $2007\left(\mathrm{H}^{\prime}=2,60\right)$. Em ambos os anos, os 
pontos menos diversificados localizam-se a oeste da malha amostral, onde há maior concentração de carbono orgânico, enxofre e lama.

O controle 1 é mais diverso que todas as estações de 2006 e de $2007\left(\mathrm{H}^{\prime}=2,63 ; \mathrm{E}_{\mathrm{H}^{\prime}}=\right.$ 0,84). Já o controle 2 é mais diversificado que 9 estações de 2006 e 6 estações de 2007 $\left(\mathrm{H}^{\prime}=2,58 ; \mathrm{E}_{\mathrm{H}^{\prime}}=0,78\right)$. Essa maior diversidade encontrada nos pontos controles pode ser decorrente da maior diversidade dos foraminíferos vivos desses pontos.

No período de 2005 nas Cigarras, na mesma malha amostral, o índice de Shannon e a equitatividade oscilam entre 0, 31 a 2,85 e 0,09 a 0,85, respectivamente. De acordo com Teodoro et al. (2009), que analisou a mesma malha amostral ao redor do emissário das Cigarras, o ano de 2005 apresenta maior riqueza e densidade que os anos seguintes. Constata-se redução no número de espécies de 2005 para 2006 com posterior aumento em 2007. Da mesma maneira, ocorre o mesmo com os índices de diversidade de Shannon, que variam entre 0,31 a 2,85. O menor valor foi encontrado logo na saída dos difusores. Os pontos 1 e 9 apresentam baixa diversidade, enquanto que os demais possuem diversidade superior a 2, 40 (Teodoro et al., 2009). Assim, em 2005, de uma maneira geral, há maior diversidade do que nos anos posteriores, porém as equitatividades são semelhantes. Essa oscilação entre os anos pode indicar a existência de uma instabilidade da comunidade de foraminíferos, devido ao estresse ambiental causado pela disposição de esgoto na região.

De acordo com estudos realizados por Du Châtelet et al. (2009), sedimentos constituídos por partículas grossas (moda > $195 \mu \mathrm{m}$ ) apresentam baixa riqueza e densidade de foraminíferos, enquanto que sedimentos finos possuem alta riqueza e diversidade. $\mathrm{Na}$ área de estudo não se verifica relação direta entre a granulometria e a riqueza e diversidade.

A principal subordem é a Rotaliina, representando mais de $92 \%$ dos foraminíferos das amostras. Estes resultados corroboram com Murray (1973), que diz que essa subordem predomina sobre as demais em ambientes marinhos da plataforma continental. De acordo com Teodoro (2006), foraminíferos rotalíneos também são majoritários em Santos e no Guarujá.

O gênero dominante, na região da malha amostral círculo crescente, é Ammonia spp., enquanto que nos controles é Pararotalia cananeiaensis. 
Indivíduos do gênero Ammonia são caracterizados por serem oportunistas já que se adaptam facilmente às condições adversas para outras espécies, como a ampla variação da salinidade. Esses organismos persistentes tornam-se dominantes após modificações ambientais da área, ocupando nichos vagos por espécies sensíveis (Bonetti, 2000). Assim, a dominância desse gênero ao redor do emissário submarino pode estar relacionada com condições ambientais desfavoráveis para outras espécies mais sensíveis. Como os pontos controles são mais distantes do efluente, e sofrem maior influência de águas marinhas trazidas pelas correntes ao longo do canal, há o predomínio da $P$. cananeiaensis.

Nas estações de 2006 e de 2007, as principais espécies, em ordem decrescente de abundância, são: A. tepida, P. cananeiaensis e A. parkinsoniana, enquanto que nos controles são: P. cananeiaensis, A. tepida e A. parkinsoniana. De acordo com os estudos de Teodoro et al. (2009), em 2005 as principais espécies são A. tepida seguida pela P. cananeiaensis. Observa-se que as contribuições de A. parkinsoniana são pequenas, diferindo neste aspecto dos anos de 2006 e de 2007. Os gêneros com maior ocorrência nos três anos são: Pararotalia, Ammonia e Cribroelphidium.

Já na região do emissário submarino de esgoto de Santos e do Guarujá há predomínio de P. cananeiaensis, sendo que exemplares do gênero Ammonia ocorrem com baixa frequência (Teodoro, 2006).

Nos anos de 2006 e de 2007 há predomínio de carapaças médias, enquanto que nos controles as pequenas são dominantes. Quando as partículas sedimentares entram em suspensão, elas podem ser carregadas por longas distâncias, tendo seu comportamento físico determinado pela velocidade de deposição. As carapaças dos foraminíferos são suscetíveis à movimentação da água, sendo um importante fator para a sua dispersão, principalmente entre os mortos (Alve, 1999). Dessa maneira, carapaças muito grandes e grandes depositam-se em ambientes de maior hidrodinâmica, enquanto que tecas médias e pequenas sedimentam-se em locais de menor energia.

Assim, a diferença morfométrica entre os controles e os demais pontos pode ser explicada pela diferença da hidrodinâmica. Os pontos localizados próximos ao emissário ficam sujeitos a uma maior energia de fundo, permitindo que haja a deposição preferencialmente de espécies médias. Já nos pontos controles, a energia de fundo é menor, permitindo então a deposição de espécimes menores. Assim, verifica-se que 
enquanto a região circunjacente ao emissário apresenta hidrodinâmica que oscila entre fraca e moderada, a região dos pontos controles é caracterizada por uma fraca hidrodinâmica.

De acordo com a análise tafonômica, testas parcialmente fragmentadas constituem a maioria em 2006 e 2007. Já nos pontos controles as carapaças inteiras são majoritárias. Esses resultados indicam que as carapaças da região próxima ao emissário ficam mais susceptíveis ao retrabalhamento antes de serem depositadas do que as dos controles. Isso ocorre provavelmente pela variação da hidrodinâmica das duas regiões, sendo que nas Cigarras a circulação de fundo é maior do que próxima aos pontos controle.

Carapaças de coloração normal constituem mais de $90 \%$ dos foraminíferos, porém também são encontradas carapaças limonitizadas, preenchidas com monossulfeto de ferro e piritizadas. A contribuição de testas piritizadas ou preenchidas com monossulfeto de ferro aumentou de 2006 para 2007, já que passaram a ocorrer em todas as estações. Elas também estão presentes nos controles em pequenas porcentagens no controle 2 e maiores no controle 1 (até 7\%).

A formação da pirita ocorre em sedimentos anóxicos, onde a matéria orgânica é consumida por bactérias anaeróbias obrigatórias redutoras de sulfato (dissolvidos na água do mar) através da seguinte reação: $2 \mathrm{CH}_{2} \mathrm{O}+\mathrm{SO}_{4^{--}} \rightarrow \mathrm{H}_{2} \mathrm{~S}+2 \mathrm{HCO}_{3}^{-}$(Berner e Raiswell, 1983). O gás sulfídrico $\left(\mathrm{H}_{2} \mathrm{~S}\right)$ gerado pela reação reage com detritos de minerais de ferro para formar sulfetos, principalmente a pirita $\left(\mathrm{FeS}_{2}\right)$ (Berner, 1982). A formação de pirita não ocorre imediatamente após o enterramento da matéria orgânica, mas sim de maneira gradual.

Geralmente, aumentos nos teores de matéria orgânica são acompanhados pelo acréscimo de minerais de ferro, já que ambos são adsorvidos, de forma coloidal, nos minerais argilosos. Isso ocorre devido à lenta deposição desses compostos, que acabam concentrando-se em locais de sedimentos finos, que possuem maior área de adsorção para o ferro e para a matéria orgânica (Berner, 1982).

A matéria orgânica, depositada no fundo oceânico, é constituída por uma variedade de compostos que reagem em diferentes graus com o sulfato. Em locais de rápida deposição, ou alta produtividade, os compostos orgânicos mais reativos em vez de serem metabolizados por processos aeróbios, na interface entre sedimento e água e sobre ela, são 
enterrados na zona de subsuperfície da redução de sulfato. Assim, esses sedimentos apresentam maiores taxas de redução de sulfato e consequentemente mais abundância de $\mathrm{H}_{2} \mathrm{~S}$ para reagir com ferro (Berner e Raiswell, 1983).

Já em locais de lenta deposição, ou baixa produtividade, a matéria orgânnica é submetida preferencialmente ao consumo aeróbio ao invés de ser enterrada. Isso faz com que apenas os compostos menos reativos e menores quantidades de matéria orgânica fiquem disponíveis para a redução do sulfato. Assim, a redução do sulfato torna-se menor, tendo menos $\mathrm{H}_{2} \mathrm{~S}$ disponível para reagir com ferro, resultando em menor conversão de ferro em pirita (Berner e Raiswell, 1983). Provavelmente é isso que ocorre nas Cigarras, já que há tecas piritizadas nas estações, porém em pequenas porcentagens. Assim, a área de estudo é constituída de subambientes com características moderadamente redutoras, corroborando com os valores obtidos na razão C/S.

Indicadores de matéria orgânica estão presentes em todos os pontos amostrais, de forma acessória, sendo mais abundantes em 2007. Os grupos mais representativos de 2006, 2007 e controle 1 são Bolivina spp., Pseudononion spp., Bulimina spp. e Buliminella elegantissima. Já no controle 2, os mais representativos são Bolivina spp., Bulimina spp. e Cassidulina spp. O controle 1 apresenta maior quantidade de indicadores de matéria orgânica quando comparado aos demais pontos amostrais. Já o controle 2 apresenta quantidades inferiores desses indicadores apenas do que a estação 1 de 2006 e a 8 de 2007.

Já em 2005 os grupos mais representativos são Bolivina spp., Pseudononion spp., Bulimina spp. (Teodoro et al., 2009). Enquanto em 2006 e em 2007 a espécie Bolivina pulchella é o principal indicador de matéria orgânica, em 2008 é a Bulimina marginata.

Assim como na área de estudo, Teodoro (2006) encontrou indicadores de matéria orgânica em todas as estações de Santos e Guarujá com ocorrência de forma acessória.

Indicadores de oxigênio não estão presentes em todas as estações e ocorrem de forma rara. Indicadores de ambiente rico em oxigênio ocorrem em maiores freqüências nos pontos controles. O ano de 2007 apresenta mais representantes desses indicadores do que 2006, permitindo inferir melhora na circulação local, mas ainda sem proporcionar ambientes bem oxigenados para aumentar em grandes quantidades esses indicadores. A principal espécie de 2006 e de 2007 é a Hanzawaia boueana, enquanto que nos pontos controles é a Discorbis williamsoni. 
Já em Santos e no Guarujá, indicadores de oxigênio estão presentes em todos os pontos amostrais, ocorrendo de forma acessória na primeira região, e rara na maioria dos pontos da segunda área (Teodoro, 2006).

De acordo com o índice de diversidade de Shannon $\left(\mathrm{H}^{\prime}\right)$, há aumento da diversidade de 2006 para 2007 nos pontos amostrais. Em 2006, a diversidade e a equitatividade oscilam entre 1,93 a 2,60 e 0,68 a 0,85, respectivamente. Já em 2007, a diversidade e a equitatividade oscilam entre 2,11 a 2,60 e 0,68 a 0,86, respectivamente. O ponto 8 possui a maior diversidade em 2006 e em $2007\left(\mathrm{H}^{\prime}=2,60\right)$. Em ambos os anos, os pontos menos diversificados localizam-se a oeste da malha amostral.

O controle 1 é mais diverso que todas as estações de 2006 e de $2007\left(\mathrm{H}^{\prime}=2,63\right.$; $\mathrm{E}_{\mathrm{H}^{\prime}}=$ 0,84). Já o controle 2 é mais diversificado que 9 estações de 2006 e 6 estações de 2007 $\left(H^{\prime}=2,58 ; E_{H^{\prime}}=0,78\right)$. Essa maior diversidade encontrada nos pontos controles pode ser decorrente da maior diversidade dos foraminíferos vivos desses pontos.

No período de 2005 nas Cigarras, na mesma malha amostral, o índice de Shannon e a equitatividade oscilam entre 0,31 a 2,85 e 0,09 a 0,85, respectivamente. O menor valor foi encontrado logo na saída dos difusores. Os pontos 1 e 9 apresentam baixa diversidade, enquanto que os demais possuem diversidade superior a 2, 40 (Teodoro et al., 2009). Assim, em 2005, de uma maneira geral, há maior diversidade do que nos anos posteriores, porém as equitatividades são semelhantes.

O modo Q, o ano de 2006 apresenta um agrupamento a mais que 2007. Algumas estações constituintes do agrupamento 1 de 2006 também ocorrem no agrupamento 2 de 2007 (\# 1, 3 e 7).

Já pelo modo R, apesar de 2007 apresentar um agrupamento a mais, os foraminíferos mais representativos são os mesmos. Ambos os anos são representados por espécimes oportunistas, indicadoras de matéria orgânica, de ambiente costeiro e de ambiente marinho. Os indivíduos oportunistas, indicadores de matéria orgânica e de ambiente costeiro refletem a biocenose da região. Já os indicadores de ambiente marinho provavelmente sofreram transporte para o local. 


\subsubsection{Biocenose}

Segundo Murray (1991), normalmente a tanatocenose apresenta maior diversidade que a biocenose, já que a primeira é constituída pelas sucessivas contribuições das associações vivas que mudam constantemente com o tempo. Isso é observado na região do estudo, já que as tanatocenoses são mais ricas e abundantes, chegando a ter até 5 vezes mais espécies, em algumas estações, do que a biocenose. Essa diferença entre a tanatocenose e a biocenose de cada ano é constatada também pelo Teste Kruskal Wallis, já que a diferença entre mortos e vivos de cada período é considerada extremamente significativa $(\mathrm{p}<0,01)$.

Da mesma maneira que nas Cigarras, no estuário de Bilbao (Leorri et al., 2008), a tanatocenose é mais abundante e apresenta maior diversidade do que a biocenose. Isso é explicado pelo transporte de carapaças mortas para a região do estudo.

Há aumento de riqueza e de densidade na maioria das estações de 2006 para 2007. O mesmo acontece entre os foraminíferos mortos. Isso pode ocorrer provavelmente pelo fato do meio apresentar características ambientais ligeiramente mais favoráveis, possibilitando aumento na abundância e na riqueza da maioria dos pontos amostrais. A estação 2 de 2006 apresenta a maior densidade e riqueza do estudo.

De acordo com estudos realizados ao redor do emissário de esgoto na Virgínia, Estados Unidos, a densidade dos foraminíferos vivos aumenta conforme se distancia do emissário submarino. A estação localizada na desembocadura do emissário possui densidade e riqueza inferior a todas as demais (Bates \& Spencer, 1979). O mesmo não ocorre nas Cigarras, já que o ponto 1, localizado na saída dos difusores, é mais rico e denso do que outras estações mais afastadas do mesmo.

Em relação aos controles, o 2 é mais abundante que o 1 e que alguns pontos de 2006 e de 2007. Já os valores de riqueza dos controles são superiores à maioria dos demais pontos amostrais. Essa maior quantidade de espécies presentes nos controles pode estar relacionada as melhores condições ambientais e mais homogêneas, permitindo então o desenvolvimento de uma maior variedade de espécies, sem excluir as mais sensíveis, e consequentemente impede o desenvolvimento de apenas espécies oportunistas. 
Os resultados obtidos pelo teste estatístico ANOVA confirmam a semelhança existente entre os anos de 2006 e de 2007, corroborando com as densidades e as espécies encontradas nesses anos, assim como em suas distribuições. Já em relação aos controles observa-se diferença significativa. Isso ocorre devido às diferenças entre densidade e as espécies encontradas. Essa diferença da biocenose próxima ao emissário com as estações do canal (controles) demonstra que o efluente está afetando e modificando as associações dos foraminíferos.

Em 2005, nas Cigarras, foram utilizados de 30 a $60 \mathrm{~cm}^{3}$ de sedimento para se obter pelo menos 100 indivíduos vivos (Teodoro et al., 2009). Já em 2006 e em 2007 foi necessário analisar apenas $10-20 \mathrm{~cm}^{3}$ de sedimento.

Estudos realizados em outros emissários submarinos de São Sebastião revelam a necessidade de um volume maior de sedimento para contabilizar no mínimo 100 testas vivas. Para os sedimentos do DTCS são necessários de 40 a $60 \mathrm{~cm}^{3}$, para o Araçá, 10 a 40 $\mathrm{cm}^{3}$ enquanto que no Saco da Capela, 60 a $110 \mathrm{~cm}^{3}$ de sedimento (Duleba, 2007). Amostras de Santos, assim como os outros emissários de São Sebastião utilizam-se até $110 \mathrm{~cm}^{3}$ de sedimento para obter 100 indivíduos corados (Teodoro, 2006; Duleba, 2007).

Estudos realizados no estuário de Bilbao (Espanha), contaminado por metais pesados, utilizaram $80 \mathrm{~cm}^{3}$ de sedimento em cada ponto amostral para analisar o conteúdo de foraminíferos vivos. Mesmo utilizando-se esse alto volume de sedimento, o número de indivíduos vivos encontrados foi extremamente baixo, e apenas em algumas estações foi possível obter-se 100 indivíduos corados. Isso provavelmente é decorrente das condições ambientais desfavoráveis para o crescimento e reprodução desses organismos (Leorri et al., 2008).

A partir desses resultados, pode-se inferir que a região das Cigarras permite o desenvolvimento e reprodução dos foraminíferos, já que na maioria das estações dos anos do estudo foi necessário apenas de $10 \mathrm{~cm}^{3}$ de sedimento para se obter pelo menos 100 indivíduos vivos.

Yanko et al., (1994) estudando região adjacente ao emissário submarino de esgoto doméstico em Israel, notaram que as estações localizadas próximas aos difusores apresentam as menores densidades populacionais. O mesmo não ocorre nas Cigarras, já que a estação localizada próxima a disposição do efluente, tanto na tanatocenose quanto 
na biocenose, está entre os pontos amostrais de maior densidade de indivíduos. Corroborando com os dados obtidos nas Cigarras, apesar do número de espécies da região circunjacente ao emissário não ser baixa, a maioria das espécies é representada por apenas alguns indivíduos.

De acordo com o índice de Shannon $\left(\mathrm{H}^{\prime}\right)$, a tanatocenose é mais diversa que a biocenose, sendo o controle 1 a estação mais diversificada de todas. O controle 2 é mais diversificado que a maioria dos pontos amostrais.

Na biocenose de 2006, os valores de diversidade e equitatividade variam entre 1,04 a 1,52 e 0,50 a 0,79, respectivamente. Em 2007, os valores de diversidade e equitatividade oscilam entre 1,23 a 1,87 e 0,56 a 0,75, respectivamente. Assim, da mesma maneira que o obtido na tanatocenose, de 2006 para 2007 há acréscimo na diversidade de Shannon proporcionada possivelmente pela melhora na qualidade ambiental da região.

Nos mortos de 2006, a estação 8 é tida como a de maior diversidade, sendo que ela apresenta os maiores teores de enxofre e razão C/S. Já nos vivos, esta estação está entre uma das menos diversas. Isso mostra que o uso da tanatocenose para o monitoramento ambiental pode acarretar em interpretações erradas, não condizentes com a realidade local.

O controle 2 é o mais diversificado dentre todos os pontos amostrais $\left(\mathrm{H}^{\prime}=2,14 ; \mathrm{E}_{\mathrm{H}^{\prime}}=\right.$ 0,86). Já o controle 1 apresenta maior diversidade que todas as estações de 2006 e metade das de $2007\left(\mathrm{H}^{\prime}=1,62 ; \mathrm{E}_{\mathrm{H}^{\prime}}=0,65\right)$. Assim, conclui-se que o controle 2, que está mais distante do emissário submarino, sofre menor influência do efluente, possibilitando condições ambientais propícias para uma maior diversidade de espécies. Da mesma maneira que nas Cigarras, na costa de Israel, a região próxima a um emissário submarino também apresenta densidade e diversidade de foraminíferos inferiores ao ponto controle (Yanko et al., 1994).

Nas Cigarras em 2005, o índice de Shannon e a equitatividade da biocenose oscilou entre 0, 22 a 1, 25 e 0,16 a 0,46, respectivamente (Teodoro et al., 2009). Assim, diferentemente do que ocorre na tanatocenose nos mesmos períodos, verifica-se aumento da diversidade e equitatividade com o passar dos anos.

Na região circunjacente ao emissário do Araçá, a diversidade de Shannon varia entre 1,77 a 2,86, e a equitatividade oscila entre 0,72 a 0,92. Já no Saco da Capela, os valores 
do índice de diversidade de Shannon e sua equitatividade oscilam entre 2, 49 a 2,94 e 0,78 a 0,96, respectivamente (Teodoro et al., 2010). Isso demonstra que as Cigarras possuem a menor diversidade e equitatividade de foraminíferos nas regiões circunjacentes aos emissários do Canal de São Sebastião, provavelmente devido às diferenças nos parâmetros abióticos de cada região.

Tanto na tanatocenose quanto na biocenose, verifica-se dominância de rotalíneos frente à milionídeos e textularíneos, corroborando os resultados obtidos por Bandy et al (1964), Teodoro (2006) e Teodoro et al. (2010).

Os gêneros e espécies presentes nos anos de 2006 e 2007 são muito semelhantes entre si, porém diferem dos controles. Assim como o encontrado por Bandy et al. (1964) e Yanko et al. (1994), a riqueza é reduzida e há dominância de algumas espécies.

Da mesma maneira que nos mortos, as biocenoses apresentam predomínio do gênero Ammonia, com maior representatividade em 2006, assim como no emissário submarino do Araçá, do Saco da Capela (Teodoro et al. 2010) e de Montevideo (Burone et al., 2006). Segundo Walton e Sloan (1990), indivíduos desse gênero conseguem viver em sedimentos finos (silte e argila), assim como em sedimentos mais grossos (areia). Eles são capazes de sobreviver em baixas temperaturas $\left(0-5^{\circ} \mathrm{C}\right)$, assim como em uma ampla variação de salinidade $(<1 \%$ e $>90 \%$ o), porém sua reprodução fica restrita a temperaturas de 17-32 oC e salinidades entre 15-40 \%o (Walton e Sloan, 1990).

Ensaios laboratoriais demonstram que indivíduos de Ammonia sobrevivem pelo menos um dia em condições anóxicas. Em culturas pobres em oxigênio, os espécimes aumentam o número de poros de suas paredes, visando ter um melhor acesso ao oxigênio (Moodley e Hess, 1992). Assim, a dominância desse gênero pode ser decorrente de características ambientais menos favoráveis para espécies mais sensíveis, priorizando espécies oportunistas.

Em todas as estações, a espécie dominante é a A.tepida, seguida pela $A$. parkinsoniana. De acordo com Poag (1976 apud Martins e Gomes, 2004), essa espécie é mais abundante em ambientes não poluídos, enquanto a $A$. tepida é muito mais tolerante à poluição. Isso pode explicar o fato da área de estudo apresentar maiores quantidades de espécimes de A. tepida do que de A. parkinsoniana. 
Da mesma maneira que na área de estudo, a A. tepida é uma das espécies mais comuns da região do estuário de Bilbao (Leorri et al., 2008). Em Israel, um estudo também demonstra que essa espécie domina tanto o ponto controle, caracterizado por maior diversidade e abundância, quanto o ponto localizado próximo a deposição de lodo ativado (Hyams-Haphzan et al., 2009). Isso também é constatado nas Cigarras, onde os pontos controles apresentam maior abundância que os demais, porém também são dominados por exemplares de $A$. tepida.

No ano de 2006, 2007 e controle 2, a terceira espécie mais significativa é a $B$. striatula, enquanto que no controle 1 são as B. doniezi e B. elegantissima. Essa diferença entre os controles é confirmada pelo Teste Kruskal Wallist entre esses dois pontos, já que o p< 0,01 .

De acordo com dados obtidos nas Cigarras em 2005, a principal espécie é a A. tepida, seguida da B.striatula (Teodoro et al., 2009).

Da mesma maneira que as Cigarras, o grupo dominante na região do emissário de Santos é Ammonia spp., seguido por indivíduos de $P$. cananeiaensis. Representantes de $B$. striatula ocorrem em baixas frequências em todas as estações (Teodoro, 2006).

Indivíduos de $P$. cananeiaensis que são abundantes na tanatocenose ocorrem somente em algumas amostras de vivos e com frequências relativas muito pequenas (até 2,0\%), indicando possível transporte dessa espécie para a área de estudo. De acordo com Debenay et al. (2001), no canal de São Sebastião a abundância e distribuição da $P$. cananeiaensis pode estar relacionada a dois motivos. O primeiro é que ela pode ser uma espécie costeira abundante ao longo da costa brasileira. O segundo é que testas vazias dessa espécie são transportadas por correntes e pela ação das ondas, fazendo com que a distribuição das associações mortas não reflita a ecologia da espécie. Isso explica porque há grande contribuição dessa espécie entre os mortos, e sua baixa frequência nas biocenoses.

Da mesma maneira que as tanatocenoses de 2006 e 2007, as biocenoses apresentam majoritariamente carapaças médias, seguidas pelas pequenas e grandes. Já nos pontos controles, testas pequenas são predominantes, seguidas pelas médias. Segundo Bernhard (1986), o tamanho das carapaças é diretamente proporcional à quantidade de oxigênio disponível no ambiente. Carapaças grandes necessitam de muito oxigênio, ficando 
restritas a regiões aeróbias e de forte hidrodinamismo. Já ambientes disaeróbios $\left(1\right.$ a 0,1 $\mathrm{O}_{2}$ $\mathrm{mg} / \mathrm{L}$ ) possuem baixos teores de oxigênio, sendo suficiente apenas para manter o metabolismo de foraminíferos de carapaças reduzidas (Bernhard e Alve, 1996). Isso demonstra que embora a região apresente, em alguns pontos amostrais, teores de OD inferiores ao estipulado pelo CONAMA na coluna d'água, no sedimento e próximo à ele há oxigênio suficiente para permitir a ocorrência de foraminíferos maiores, já que também estão presentes indivíduos grandes em 2006 e 2007. Nos pontos controles os teores de OD dos sedimentos devem ser inferiores, já que há o predomínio de carapaças pequenas.

Diferentemente das tanatocenoses de 2006 e de 2007, a análise morfológica revela predomínio de testas inteiras em metade das amostras de 2006, e domínio de parcialmente fragmentadas no restante. Já em 2007, tecas inteiras dominam todas as estações. Dessa maneira, infere-se que em 2006 os foraminíferos sofrem retrabalhamento local maior, que pode ser provocado por bioperturbadores ou pela maior energia de fundo em alguns locais. Nos pontos controles, tanto nos mortos quanto nos vivos, as testas inteiras são majoritárias. O predomínio de tecas inteiras em contraste com as parcialmente fragmentadas das tanatocenoses (2006 e 2007) ocorre provavelmente pelo fato dos foraminíferos vivos terem maior controle sobre sua movimentação, podendo enterrar-se ou fixar-se em algum substrato. Já após sua morte, as carapaças passam a se comportar como um grão de sedimento, ficando susceptíveis às movimentações das correntes de água, e consequentemente a um retrabalhamento antes de sua deposição.

Da mesma maneira que a tanatocenose, indicadores vivos de matéria orgânica ocorrem em todos os pontos amostrais, com ocorrência majoritariamente acessória. $\mathrm{Na}$ biocenose, os indicadores de matéria orgânica são semelhantes em 2006, 2007 e controles, sendo mais abundante no penúltimo. Os grupos mais representativos são B. striatula, Bolivina spp. e B. elegantissima, apresentando variações na ordem de importância dos grupos entre os controles. Isso indica que na região há matéria orgânica disponível para os foraminíferos, favorecendo a ocorrência desses indicadores.

No ano de 2005, os grupos indicadores de matéria orgânica são os mesmo que dos anos seguintes (Teodoro et al., 2009). Da mesma maneira, Santos apresenta esses indicadores em todas as estações, porém de maneira acessória e subdominante. Já no 
Guarujá eles ocorrem em apenas metade das estações, mas são subdominantes e dominantes (Teodoro, 2006).

Estudos realizados em emissário submarino da Califórnia revelaram que a espécie B. elegantissima é uma das principais espécies vivas, perfazendo até $50 \%$ da biocenose em estações próximas ao emissário (Bandy et al., 1964). Isso não ocorre na região de estudo, onde exemplares dessa espécie apresentam frequências relativas máximas de 4,6\%.

Em relação aos indicadores de oxigênio, a tanatocenose apresenta duas espécies a mais que a biocenose. Há indicadores mortos em quase todas as estações, enquanto que indivíduos vivos ocorrem em apenas poucas estações e com baixas frequências.

Na biocenose, em 2006 eles estão presentes apenas na estação 8, enquanto que em 2007 eles ocorrem nos pontos 1, 2, 3 e 5. Esse aumento de indicadores de oxigênio de um ano para o outro deve estar relacionado às melhores condições de oxigenação da coluna d'água. Há representantes apenas da espécie $N$. terquemi e D. bertheloti. Já nos pontos controles, esses indicadores são inexistentes. Talvez isso ocorra pela baixa hidrodinâmica local, que possibilita apenas a ocorrência de espécimes pequenos, já que o oxigênio é suficiente apenas para manter seu metabolismo. Dessa maneira, não há foraminíferos indicadores de ambiente rico em oxigênio.

Segundo Teodoro et al. (2009), as Cigarras apresenta espécies indicadoras de oxigênio de forma rara e apenas em 3 estações. Assim, pode-se concluir que a malha amostral circujancente ao emissário submarino é uma região com baixos teores de oxigenação próxima ao fundo e entre os sedimentos.

Em amostras de Santos (Teodoro, 2006), indicadores de oxigênio ocorrem na maioria dos pontos amostrais, porém também sempre de forma rara. No Guarujá, assim como nas coletas de 2006 das Cigarras, esses indicadores estão presentes em apenas uma estação.

O fato das tanatocenoses de 2006 e de 2007 apresentarem maiores quantidades desses indicadores do que nas respectivas biocenoses, pode ser explicado pelo transporte desses representantes para as áreas de amostragem. $\mathrm{O}$ mesmo ocorre entre os indicadores mortos do controle, que provavelmente viviam em outras áreas mais oxigenadas, e que depois de sua morte sofreram transporte para a área de amostragem dos controles. 
O ano de 2007 apresenta maior quantidade de indicadores de matéria orgânica e de oxigênio provavelmente por causa de um maior aporte de material do emissário submarino, assim como pelo aumento na circulação de fundo na região.

Em relação ao agrupamento no modo $Q$, verificam-se diferenças entre a tanatocenose e a biocenose. Em 2006, alguns pontos amostrais que se encontram em um mesmo grupo na tanatocenose também estão juntos na biocenose, como é o caso das estações 1, 3 e 7; 2 e 5 . O mesmo ocorre em 2007 com as estações 1 e 2; 3 e 7.

Nos vivos de 2006 e de 2007 observa-se semelhança nos agrupamentos, já que as estações 5 e 10; 3, 6, 7 e 9; 4 e 8 encontram-se agrupadas nos dois anos.

Já a partir da análise no modo $\mathrm{R}$, pode-se inferir que tanto a biocenose como a tanatocenose apresentam representantes oportunistas e indicadores de matéria orgânica, porém os mortos também são constituídos por espécies indicativas de ambiente costeiro e de influência marinha.

Entre os vivos há contribuição das mesmas espécies, porém em 2007 há similaridade entre as espécies A. tepida e A. parkinsoniana, enquanto que em 2006 há maior similaridade entre A. tepida e B. striatula. A presença dessas espécies demonstra que a área de estudo é constituída principalmente por foraminíferos indicadores de matéria orgânicas, devido ao enriquecimento da região, e oportunistas que resistem a condições ambientais desfavoráveis para espécies mais sensíveis.

De acordo com a análise canônica, verifica-se que o uso da tanatocenose para o monitoramento ambiental não é válido e gera resultados errados. Na biocenose, as duas variáveis ambientais que controlam os foraminíferos são o diâmetro médio e o enxofre, enquanto que na tanatocenose é o diâmetro médio e o carbono orgânico. Além disso, o número de espécies que faz parte da análise é muito maior nos mortos, já que eles são resultantes da deposição de carapaças de muitos períodos.

Indivíduos do gênero Bolivina, Brizalina e Pseudononion são indicadores de ambiente rico em matéria orgânica. Assim, essas espécies devem estar relacionadas a maiores concentrações de carbono orgânico, fato este que não ocorre nas tanatocenoses.

Os gráficos resultantes das estações com os parâmetros abióticos estão de acordo com os dados granulométricos e geoquímicos dos dois períodos analisados no estudo. Assim, as estações, na análise da tanatocenose, que apresentam maiores contribuições de 
lama também possuem os maiores teores de carbono orgânico. Da mesma maneira, na biocenose, as estações que apresentam as maiores porcentagens de lama são as que apresentam maiores teores de enxofre, corroborando com os dados geoquímicos e granulométricos do período.

Os pontos controles apresentam-se mais afastados das demais estações, com exceção do ponto 8 de 2006. Isso demonstra diferenças entre os controles e as demais estações, que pode ser explicado provavelmente pela maior distância dos mesmo em relação à disposição do efluente. 


\section{CONCLUSÕES}

Os parâmetros abióticos apresentam certa homogeneidade horizontal e vertical ao longo da coluna d'água. Contudo, os menores teores de oxigênio dissolvido encontrados em 2006 provavelmente estão relacionados ao maior aporte de matéria orgânica, proveniente do efluente, que também gerou altos valores de turbidez. Assim, foram requisitados altos valores de oxigênio no processo de degradação da matéria orgânica introduzida. Já no ano seguinte, os teores de oxigênio dissolvido tiveram acréscimo causado provavelmente pela redução do volume de efluente disposto e por maior circulação local. Isso reflete nos menores valores de turbidez encontrados nesse ano. O controle 1 apresenta teor de oxigênio dissolvido abaixo do CONAMA provavelmente devido a redução da circulação local, assim como sua maior proximidade do continente e do emissário submarino.

A região ao redor do emissário apresenta predomínio de sedimentos arenolamosos, indicando circulação de fundo fraca a moderada, fato este que coaduna com a dominância de tecas médias, seguidas pelas pequenas. Já nos controles, a predominância da fração de areia fina, assim como de testas pequenas indicam menor hidrodinâmica desta região.

A divergência entre as tanatocenoses $\mathrm{e}$ as biocenoses comprova que muitos foraminíferos mortos sofreram retrabalhamento e transporte para as áreas estudadas, não representando, portanto a verdadeira assembléia desses organismos vivos. Isso comprova a importância da utilização de exemplares vivos em estudos de impacto ambiental.

$\mathrm{O}$ fato das biocenoses da área circunjacente ao emissário serem extremamente diferentes dos pontos controles demonstra que o efluente proveniente do emissário de esgoto está afetando e alterando as associações desses organismos bentônicos. Como os pontos controles encontram-se mais distantes do emissário, verifica-se maior abundância e diversidade dos mesmos.

Carapaças parcialmente fragmentadas constituem a maioria entre as tanatocenoses, demonstrando o retrabalhamento das mesmas antes de sua deposição, já que se comportam como um grão de sedimento após a morte do organismo. Já entre os vivos há predomínio de tecas inteiras, uma vez que os foraminíferos vivos conseguem manter-se fixos a substratos e apresentam maior controle de movimentação. Carapaças de coloração 
normal predominam, porém a presença de tecas limonitizadas, piritizadas ou preenchidas como monossulfeto de ferro inferem subambientes com características redutoras, fato este que corrobora com a escassez de foraminíferos indicadores de ambiente oxigenado, assim como com os teores de enxofre encontrados.

O domínio do gênero Ammonia em todas as frações analisadas revela que o ambiente está favorecendo espécies oportunistas, que conseguem se adaptar à variações ambientais. Já o predomínio de indivíduos da espécie Pararotalia cananeiaensis entre os mortos do controle indica maior influência marinha na região.

A presença de gêneros e espécies indicadoras de matéria orgânica em toda a malha amostral demonstra enriquecimento dos sedimentos da área de estudo, proveniente da disposição de esgoto do emissário submarino.

Não foi possível determinar se as concentrações de HPAs dos sedimentos estão prejudicando os foraminíferos, sendo necessários estudos posteriores.

Desta maneira, pode-se concluir que o efluente proveniente do emissário de esgoto está afetando negativamente os foraminíferos, favorecendo espécies oportunistas e propiciando instabilidade em suas associações. Além disso, o esgoto está causando o enriquecimento dos sedimentos da região de estudo, assim como subregiões com características redutoras. Os resultados também demonstram a importância de se estudar os sedimentos juntamente com a coluna d'água para interpretações corretas do meio ambiente, já que os sedimentos são reservatórios de muitas substâncias que estavam presentes na água e em organismos. 


\section{REFERÊNCIAS BIBLIOGRÁFICAS}

ACHER, A.; FISCHER, E.; TURNHEIN, R.; MANOR, Y. Ecologically friendly wastewater desinfection thechniques. Water Research, v.31, n.6, p. 1398-1404, 1997.

AGUDO, E.G.; AMARAL, R.; BERZIN, G. Avaliação da estação pré-condicionadora do sistema de disposição oceânica dos esgotos de Santos/São Vicente. Revista DAE, v. 46, n. 146, 1986.

ALMEIDA, F. F. M. The system of continental rifts boardering the Santos Basin, Brazil. Anais da Academia Brasileira de Ciências, v. 48, p. 15-26, 1976.

ALMEIDA, F.V.; JARDIM, W.F. Determinação de compostos orgânicos (hidrocarbonetos e compostos organoclorados) em águas e sedimentos límnicos visando o estudo da partição, biodisponibilidade e toxicidade. In: MOZETO, A.A.; UMBUZEIRO, G.A.; JARDIM, W.F. Métodos de coleta, análises fisico-químicas e ensaios biológicos e ecotoxicológicos de sedimentos de água doce. São Carlos: Cubo Multimídia, 2006. p. 91-106.

ALVE, E. Colonization of new habitats by benthic foraminifera: a review. Earth Science Reviews, v.46, p.167-185, 1999.

ANDRADE, S.; ULBRICH, H. H.; JANASI, V. A.; NAVARRO, M. S. The determination of total hydrogen, carbon, nitrogen and sulfur in silicates, silicate rocks, soils and sediments. Geostandart and geoanalytical research, v.33, n.3, p.337-345, 2009.

BANDY, O. L.; INGLE, J. C.; RESIG, J. M. Foraminiferal trends, Laguna Beach Outfall area, California. Limnology and Oceanography, v. 9, n. 1, p. 112-123, 1964.

BANDY, O. L.; INGLE, J. C.; RESIG, J. M. Foraminiferal, Los Angeles County Outfall area, California. Limnology and Oceanography, v. 9, n. 1, p.124-137, 1964 a.

BARBOUR, E. K.; SABRA, A. H.; SHAIB, H. A.; BERCKLEY, A. M.; FARAJALLA, N. S.; ZURAYK, R. A.; KASSAIFY, Z. G. Baseline data of polycyclic aromatic hydrocarbons correlation to size of marine organism harvested from a war-induced oil spill zone of the Eastern Mediterranean Sea. Marine Pollution Bulletin, v. 56, n. 4, p. 770-797, 2008.

BARCELLOS, R.L.; FURTADO, V.V. Distribuição e características da matéria orgânica (C, N e S) no Canal de São Sebastião (SP), no verão de 1997. In: XI SEMANA NACIONAL DE OCEANOGRAFIA, 1998, Rio Grande. Resumos Expandidos. Rio Grande: AOCEANO, 1998. v. único. p. 454-456. 
BARCELLOS, R. L.; FURTADO, V. V. Processo sedimentar atual e a distribuição de carbono e nitrogênio orgânicos no Canal de São Sebastião (SP) e Plataforma Continental adjacente. Revista Brasileira de Oceanografia, v. 47, p. 207-221, 1999.

BARCELLOS, R. L.; FURTADO, V. V. Caracterização dos componentes da fração arenosa (0,500 mm/ 0,250 mm) no Canal de São Sebastião. Pesquisas em Geociências, v. 28, p. 35$51,2001$.

BARRICK, R. C.; PRAHL, F. G. Hydrocarbon geochemistry of the Puget Sound region III. Polycyclic aromatic hydrocarbons in sediments. Estuarine, Coastal and Shelf Science, v. 25, p.175-191, 1987.

BASHEER, C.; OBBARD, J.P.; LEE, H.K. Persistent organic pollutants in Singapore's coastal marine environment: Part II, Sediments. Water, Air and Soil Pollution, v. 149, p. 315-325, 2003.

BATES, J. M.; SPENCER, R. S. Modification of foraminiferal trends by the ChesapeakeElizabeth sewage outfall, Virginia Beach, Viriginia. Journal of Foraminiferal Research. v. 9, no 2, p.125-140, 1979.

BERNER, R. A. Burial of organic carbon and pyrite sulfur in the modern ocean: its geochimical and environmental significance. American Journal of Science, v. 282, p. 451$473,1982$.

BERNER, R. A. Sedimentary pyrite formation, an update. Geochemica et Cosmochimica Acta, v. 48, p. $605-615,1983$.

BERNER, R. A.; RAISWELL, R. Burial of organic carbon and pyrite sulfur in sediments over Phanerozoic time: a new theory. Geochimica et Cosmochimica Acta, v. 47, p. 855-862, 1983.

BERNHARD, J. M. Characteristic assemblages and morphologies of benthic foraminifera from anoxic, organic-rich deposits: Jurassic through Holocene. Journal of Foraminifera Research, v. 16, n. 3, p. 207-215, 1986.

BERNHARD, J. M.; ALVE, E. Survival, ATP pool, and ultrastructural characterization of benthic foraminifera from Drammensfjord (Norway): responde to anoxia. Marine Micropaleontology, v. 28, p. 5-17, 1996. 
BÍCEGO, M. C.; ZANARDI, E. L.; WEBER, R. R. Distribuição de hidrocarbonetos. In: PIRES-VANIN, A. M. S. (org). Oceanografia de um ecossistema subtropical: plataforma de São Sebastião, SP. São Paulo: Edusp, 2008. p. 123-139.

BOERSMA A. Foraminifera In: BOERSMA, A.; HAQ, B. Introdution to marine micropaleontology. Nova Iorque: Elsevier, 1978. p. 19-77.

BOLTOVSKOY, E.; GIUSSANI, G.; WATANABE, S.; WRIGHT, R. Atlas of benthic shelf foraminifera of southwest Atlantic. Netherlands: Dr. W. Junk, 1980. 147p.

BONETTI, C.V.D.H.C. Foraminíferos como bioindicadores do gradiente de estresse ecológico em ambientes costeiros poluídos. Estudo aplicado ao sistema estuarino de Santos - São Vicente (SP, Brasil). 2000. 229 f. Tese (Doutorado)- Instituto Oceanográfico. Universidade de São Paulo, São Paulo.

BURGESS, R. M.; TERLETSKAYA, A. V.; MILYUKIN, M. V.; POVOLOTSKII, M.; DEMCHENKO, V. Y.; BOGOSLAVSKAYA, T. A.; TOPKIN, Y. V.; VOROBYOVA, T. V.; PETROV, A. N.; LYASHENKO, A.; HO, K. T. Concentration and distribution of hydrophobic organic contaminants and metals in the estuaries of Ukraine. Marine Pollution Bulletin, v. 58, no 8, p.1103-1115, 2009.

BURONE, L.; VENTURINI, N.; SPRECHMANN, P.; VALENTE, P.; MUNIZ, P. Foraminiferal responses to polluted sediments in the Montevideo coastal zone, Uruguay. Marine Pollution Bulletin, v. 52, p. 61-73, 2006.

CANADIAN COUNCIL OF MINISTERS OF THE ENVIRONMENT (CCME). Canadian Sediment Quality Guidelines for the Protection of Aquatic Life: Polycyclic aromatic hydrocarbons (PAHs). Canadá, 1999. 16p.

CANADIAN COUNCIL OF MINISTERS OF THE ENVIRONMENT (CCME). Canadian Sediment Quality Guidelines for the Protection of Aquatic Life. Summary tables. Canadá, 2002.

CASTRO, L. A. S. Processamento de amostras para microscopia eletrônica de varredura. Pelotas: EMBRAPA Clima temperado. Documentos 93, p.13-14. 2002.

CASTRO-FILHO, B. M. Wind driven currents in the channel of São Sebastião: winter, 1979. Boletim do Instituto Oceanográfico de São Paulo, v. 38, p. 111-132, 1990.

CETECIOĞLU, Z.; INCE, B. K.; KOLUKIRIK, M.; INCE, O. 2009. Biogeographical distribution and diversity of bacterial and archaeal communities within highly polluted 
anoxic marine sediments from the Marmara Sea. Marine Pollution Bulletin, v. 58, n. 3, p. 384-395, 2009.

CETESB. Relatório de qualidade de águas litorâneas do estado de São Paulo Balneabilidade das praias 2003. São Paulo: CETESB, 2004. 59p.

CETESB. Relatório de qualidade das águas litorâneas do estado de São Paulo Balneabilidade das praias 2004. São Paulo: CETESB, 2005. 183p.

CETESB. Relatório de monitoramento de emissários submarinos. São Paulo: CETESB, 2007. 106p.

CETESB. Relatório da qualidade das águas litorâneas do estado de São Paulo 2007. São Paulo: CETESB, 2008. 294p.

CETESB. Relatório de qualidade das águas litorâneas no estado de São Paulo. São Paulo: CETESB, 2009. 332p.

CHAO, J.L.; MOTTA PACHECO, L.A. Disposição de esgotos por emissários submarinos, gerenciamento do controle da poluição e proteção da qualidade das águas costeiras. Revista DAE, n. 122, p.98-124, 1979.

CONAMA. Resolução no 357, de 17 de Março de 2005.

CUSHMAN, J. A. The Foraminifera of the Atlantic Ocean. Part IV. Lagenidae. Bulletin of United State National Museum, v. 104, p.1-178, 1923.

CUSHMAN, J. A. The Foraminifera of the Atlantic Ocean. Part VI. Miliolidae, Ophtalmidiidae and Fischerinidae. Bulletin of United State National Museum, v. 104, p.1$101,1929$.

CUSHMAN, J. A. The Foraminifera of the Atlantic Ocean. Part VII. Nonionidae, Camerinidae, Peneroplidae and Alveolinellidae. Bulletin of United State National Museum, v. 104, p.1-55, 1930.

CUSHMAN, J. A. The Foraminifera of the Atlantic Ocean. Part VIII. Rotaliidae, Amphisteginidae, Calcarinidae, Cymbaloporetiidae, Globorotaliidae, Anomalinidae, Planorbulinidae, Rupertiidae and Homotremidae. Bulletin of United State National Museum, v. 104, p.1-144, 1931.

CUSHMAN, J. A. Foraminifera, their classification and economic use. 4 ed. Massachusetts: Harvard University Press, 1950. 605 p. 
DEBENAY, J.P; PAWLOWSKI, J.; DECROUEZ, D. Les foramineferes actuaels. 3 ed. Paris: Masson, 1996.329 p.

DEBENAY, J-P.; DULEBA, W.; BONETTI, C.; MELO E SOUZA, S. H.; EICHLER, B. B. Pararotalia cananeiaensis n. SP.: indicator of marine influence and water circulation in brazilian coastal and paralic environments. Journal of Foraminiferal Research, v. 31, n. 2, p. 151-163, 2001.

DU CHÂTELET, E. A; BOUT-ROUZMAZEILLES, V.; RIBOULLEAU, A.; TRENTESAUX, A. Sediment (grain size and clay mineralogy) and organic matter quality control on living benthic foraminifera. Revue de micropaléontologie, v. 52, p. 75-84, 2009.

DULEBA, W.; COIMBRA, J.C.; PETRI, S.; BARBOSA, C.F. Foraminíferos, tecamebas e ostracodas recentes utilizados como bioindicadores em estudos ambientais brasileiros. In: SOUSA, C.R.G.; SUGUIO, K.; SANTOS, M.; OLIVEIRA, P.E. Quaternário do Brasil. 1 ed. Ribeirão Preto: Holos, 2005. p. 176-210.

DULEBA, W. Emissários submarinos: monitoramento ambiental. In: CETESB. Relatório da qualidade das águas litorâneas no estado de São Paulo- balneabilidade das praias 2006. São Paulo: CETESB, 2007. 365 p.

ERNST, S.R.; MORVAN, J.; GESLIN, E.; LE BIHAN, A.; JORISSEN, F.J. Benthic foraminiferal response to experimentally induced Erika oil pollution. Marine Micropaleontology, v. 61, p. 76-93, 2006.

FOLKS, R.L.; WARD, W.C. Brazos River bar: a study in the significance of grain size parameters. Journal of Sedimentary Petrology, v. 27, p. 3-27, 1957.

FONTES, R. F. C. As correntes no canal de São Sebastião. 1995. 159 f. Dissertação (Mestrado) Instituto Oceanográfico, Universidade de São Paulo, São Paulo.

FRONTALINI, F.; BUOSI, C.; DA PELO, S.; COCCIONI, R.; CHERCHI, A. \& BUCCI, C. Benthic foraminífera as bio-indicators of trace element pollution in the heavily contaminated Santa Gilla lagoon (Cagliari, Italy). Marine Pollution Bulletin, v. 58, p. 858$877,2009$.

FUNDESPA. Levantamento oceanográfico da área diretamente afetada por efluentes dos emissários submarinos de esgoto da SABESP, entre os municípios de São Sebastião e Mongaguá, Estado de São Paulo. Relatório final. São Paulo: Fundação de Estudos e Pesquisas Aquáticas, 1999. 2 v. 364p. 
FURTADO, V. V. Sedimentação quaternária no Canal de São Sebastião. Publicação Especial Instituto Oceanográfico da USP, São Paulo, v. 11, p. 27 - 35, 1995.

FURTADO, V. V.; FILHO, J. B.; RODRIGUES, M.; BARCELlOS, R. L. Aspectos da sedimentação no canal de São Sebastião. Relatório técnico Instituto Oceanográfico. São Paulo: USP, 1998. v. 43. p.15-31.

GOODSELL. P. J.; UNDERWOOD, A. J.; CHAPMAN, M. G. Evidence necessary for taxa to be reliable indicators of environmental conditions or impacts. Marine Pollution Bulletin, v. 58, p. 323-331, 2009.

GROSS, M. G. Carbon determinations. In: CARVER, R. G. Procedures in sedimentary petrology. p.573-596. 1971.

GUBITOSO, S.; DULEBA, W.; TEODORO, A. C.; PRADA, S. M.; ROCHA, M. M.; LAMPARELLI, C. C.; BEVILACQUA, J. E.; MOURA, D. O. Estudo geoambiental da região circunjacente ao emissário submarino de esgoto do Araçá, São Sebastião (SP). Revista Brasileira de Geociências, v. 38, n. 3, p. 467-475, 2008.

GUBITOSO, S. Influência de efluentes domésticos e petroquímicos em sedimentos e carapaças de foraminíferos do Canal de São Sebastião, SP. 2010. 122 f. Dissertação (Mestrado)- Instituto de Geociências, Universidade de São Paulo, São Paulo.

HARRAD, S. Persistent Organic Pollutants: environmental behavior and pathways for human exposure . Londres: Kluwer Academic Publishers, 2000. 272p.

HEDGES, J. L.; KEIL, R. G. Sedimentary organic matter preservation, an assessment and speculative hypothesis. Marine Chemistry, v. 49, n. 2-3, p. 81-115, 1995.

HYAMS-KAPHZAN, O.; ALMOGI-LABIN, A.; BENJAMINI, C.; HERUT, B. Natural oligotrophy vs. pollution-induced eutrophy on the SE Mediterranean shallow shelf (Israel): environmental parameters and benthic foraminifera. Marine Pollution Bulletin, v. 58, n. 12, p.1888-1902, 2009.

IBGE. Banco de dados. Disponível em: <http://www.ibge.gov.br/cidadesat/historicos_cidades/historico_conteudo.php?cod

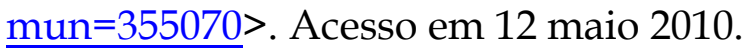

KENNISH. M. J. Ecology of estuaries: anthropogenic effects. Marine Science Series. Estados Unidos: CRC Press, 1992. 494p. 
LAMPARELLI, C. C. 2006. Desafios para o licenciamento e monitoramento ambiental de emissários: a experiência de São Paulo. In: LAMPARELLI, C. C.; ORTIZ, J. P. (org.). Emissários submarinos: projeto, avaliação de impacto ambiental e monitoramento. São Paulo: SMA, p.11-23.

LARSONNEUR, C. La cartographie de's dépots meubles sur le plateau continental français: méthode mise du points et utilisée em Manche. Journal Redi Oceanog, v.2, p.3439, 1977.

LAW, R. J. \& BISCAYA, J. L. Polycyclic aromatic htdrocarbons (PAH) - problems and progress in sampling, analysis and interpretation. Marine Pollution Bulletin, v. 29, n. 4-5, p. 235-241, 1994.

LEE, J. J.; CAPRIULO, G. M. The Ecology of marine Protozoa: an overview. In: CAPRIULO, G. M. Ecology of marine protozoa. New York: University Press, 1991. p. 186259.

LEORRI, E.; CEARRETA, A.; IRABIEN, M. J.; YUSTA, I. Geochimical and microfaunal proxies to assess environmental quality conditions during the recovery processo $\mathrm{f}$ a heavily polluted estuary: The Bilbao estuary case (N. Spain). Science of the total environment, v. 396, n. 1, p.12-27. 2008.

LIPPS, J. H. Fossil Prokaryotes and Protists. Boston: Blackwell Scientific Publications, 1993. $342 \mathrm{p}$.

LIPPS, J.H.; VALENTINE, J.W. The role of foraminifera in the trophic structure of marine communities. Lethaia, v. 3, p. 279-286, 1970.

LOEBLICH, A. R.; TAPPAN, H. 1964. Protista. In: MOORE, R.C.Treatise on invertebrate paleontology, Part C. New York: The University Kansas Press, 1964 .vol. 1, 510 p., vol. 2, $390 \mathrm{p}$.

LOEBLICH, A. R.; TAPPAN, H. Foraminiferal genera and their classification. New York: Van Nostrand, 1988. v.1, 970 p., v.2, 847 plates.

LUDWING, R.G. Planejamento e projeto de sistemas de disposição oceânica. Simpósio de tecnologia de tratamento e disposição de esgotos da organização Pan-americana de saúde-Buenos Aires, Argentina. Revista DAE, n. 113, 1977. 
MACKNIGHT, S.D. Selection of bottom sediment sampling stations. In: MUDROCH, A.; MACKNIGHT, S.D. (eds.). Handbook of techniques for aquatic sediments sampling, 2 ed., Boca Raton: CRC, 1994. p.17-27.

MAGNUSSON, W.E.; MOURÃO, G.M. Estatística sem matemática: a ligação entre as questões e as análises. Londrina: Planta, 2005. 138p.

MAGURRAN, A. E. Ecological diversity and its measurement. New York: Croom Helm, 1983. 179 p.

MALISKA, A. M. Apostila de Microscopia eletrônica de varredura. Universidade Federal de Santa Catarina, 97p. S/ ano.

MANLY, B. F.J. Multivariate statistical methods: a primer. 2 ed. Londres: Chapman \& Hall, 1994. 215p.

MARCELLINO, E. B. J. Sistematização dos projetos de emissários submarinos da SABESP $e$ avaliação de desempenho através do modelo computacional CORMIX. 2000. 272 f. Dissertação (Mestrado)- Escola Politécnica, Universidade de São Paulo, São Paulo.

MARCELLINO, E.B.; MACEDO, L. S. 2006. Emissários submarinos: critérios de localização e minimização de impactos no meio marinho. In: LAMPARELLI, C. C.; ORTIZ, J. P. (org.). Emissários submarinos: projeto, avaliação de impacto ambiental e monitoramento. São Paulo: SMA, 2006 p.43-57.

MARTINS, M. V. A. \& GOMES, V. C. R. D. Foraminíferos da margem continental nw Ibérica: sistemática, ecologia e distribuição. Portugal, 2004. 377p.

MCMANUS, J. Grain size determination and interpretation. In: TUCKER, M. Techniques in sedimentology. Londres: Blackwell Scientific Publications, 1988. p. 63-85.

MEDEIROS, P. M. Avaliação da origem de hidrocarbonetos em sedimentos marinhos de Santos e São Sebastião, utilizando-se hidrocarbonetos marcadores geoquímicos. 2000. 102 f. Dissertação (Mestrado)- Instituto Oceanográfico, Universidade de São Paulo, São Paulo.

MEDEIROS, P. M.; BÍCEGO, M. C. Investigation of natural and anthropogenic hydrocarbon inputs in sediments using geochemical markers. II. São Sebastião, SPBrazil. Marine Pollution Bulletin, v. 49, p. 892-899, 2004.

MELLO, M. S.; SINFRÔNIO, E. A. S.; GIANNINI, P. C. F; FACHINI, M.; VICTORINO, M. C. Manual de procedimentos analíticos (LABSED-Laboratório de Sedimentologia). São Paulo: USP, 2004. p.6-19. 
MILLER, A. L.; SCOTT, D. B.; MEDIOLI, F. S. Elphidium excavatum (Terquem): ecophenotypic versus subspecific variation. Journal of Foraminiferal Research, v. 12, n. 2, p.116-114, 1982.

MIRANDA, L. B.; CASTRO-ALVES. B. M. Variabilidade da circulação e do transporte de volume do Canal de São Sebastião (SP). Publicação especial Instituto Oceanográfico, v. 11, p. 1-9, 1995.

MONTONE, R. C. \& BÍCEGO, M. C. 2008. Indicadores químicos de esgoto. In: NETO, J. A. B.; WALLNER-KERSANACH, M.; PATCHINEELAM, S. (org.). Poluição marinha. 1 ed. Rio de Janeiro: Interciência, p.397-412.

MOODLEY, L.; HESS, C. Tolerance of infaunal benthic foraminífera for low and high oxygens concentrations. Biological Bulletin, v. 183, n. 1, p. 94-98, 1992.

MOJTAHID, M.; JORISSEN, F.; PEARSON, T. H. Comparison of benthic foraminifera and macrofaunal responses to organic pollution in the Firth of Clyde (Scotland). Marine Pollution Bulletin, v. 56, n. 1, p. 42-76, 2008.

MORVAN, J.; LE CADRE, V.; JORISSEN, F.; DEBENAY, J-P. Foraminifera as potencial bioindicators of the "Erika" oil spill in the Bay of Bourgneuf: field and experimental studies. Aquatic living Resources, v.17, p.317-322, 2004.

MUDROCH, A. \& MACKNIGHT, S. Handbook of techniques for aquatic sediments sampling. Boca Raton: CRC, 1994. 210p.

MURRAY, J. W. Distribution and ecology of living benthic foraminiferids. 1 ed. Londres: Heinemann education books, 1973. 274p.

MURRAY, J. W. Ecology and paleoecology of benthic foraminifera. London: Longman Scientific \& Technical, 1991. 397 p.

NUVOLARI, A. O lançamento in natura e seus impactos. In: NUVOLARI, A. Esgoto sanitário: coleta, transporte, tratamento e reuso agrícola. São Paulo: Blücher, 2003. p.171207.

PEREIRA, R. C.; GOMES-SOARES, A. 2002. Biologia Marinha. Rio de Janeiro: Interciência, 2002. 382p.

READMAN, J. W.; FILLMANN, G.; TOLOSA, I.; BARTOCCI, J.; VILLENEUVE, J.-P.; CATINNI, C.; MEE, L. D. Petroleum and PAH contamination of the Black Sea. Marine Pollution Bulletin, v.44, p.48-62, 2002. 
SABEAN, J. A. R.; SCOTT, D. B.; LEE, K.; VENOSA, A. D. Monitoring oil spill bioremediation using marsh foraminifera as indicators. Marine Pollution Bulletin, v. 59, n. 8-12, p. 352-361, 2009.

SABESP. Relatório de caracterização do sistema de tratamento e disposição final de esgotos da Praia das Cigarras. Município de São Sebastião, SP. São Paulo: SABESP, 2006.

SCHAFER, C. T. Distribution of foraminifera near pollution sources in Chaleur Bay. Water, air and soil pollution, v. 2, p. 219-233, 1973.

SCHRÖDER, C. J.; SCOTT, D. B.; MEDIOLI, F. S. Can smaller benthic foraminifera be ignored in paleoenvironmental analyses? Journal of Foraminiferal Research, v. 4, p. 101110, 1987.

SCOTT, D. B., MEDIOLI, F.S. \& SCHAFFER, C. T. Monitoring in Coastal Environments using Foraminifera and Thecamoebian Indicators. Cambridge: Cambridge University Press, 2001. 177 p.

SHEPARD, F.P. Nomenclature based on sand-silt-clay ratios. Journal Sedimentary Petrology, v. 24, p. 151-158, 1954.

SILVA, D. A. M.; BUZITIS, J.; KRAHN, M.; BÍCEGO, M. C.; PIRES-VANIN, A. M. S. Metabolites in bile of fish from São Sebastião Channel, São Paulo, Brazil as biomarkers of exposure to petrogenic polycyclic aromatic compounds. Marine Pollution Bulletin, v. 52, p. 175-183, 2006.

STEIN, R. Accumulation of organic carbon in marine sediments. Lecture Notes in Earth Sciences. Berlin: Springer-Verlag, 1991. 217 p.

SUGUIO, K. Introdução à sedimentologia. São Paulo: Edusp, 1973. 317p.

TEODORO, A. C. Estudo hidrogeoquímico, sedimentológico e de foraminíferos em áreas da Baixada Santista, SP, submetida a disposição oceânica de esgotos. 2006. 166 f. Dissertação (Mestrado)- Instituto de Geociências, Universidade de São Paulo, São Paulo.

TEODORO, A. C.; DULEBA, W.; LAMPARELLI, C. C. Associações de foraminíferos e composição textural da região próxima ao emissário submarino de esgotos domésticos de Cigarras, Canal de São Sebastião, SP. Pesquisas em Geociências, v. 36, n. 1, p. 79-94, 2009.

TEDORO, A. C.; DULEBA, W.; GUBITOSO, S.; PRADA, S,M.; LAMPARELLI, C. C.; BEVILACQUA, J. E. Analysis of foraminífera assemblages and sediment geochemical 
properties to characterise the environment near Araçá and Saco da Capela domestic sewage submarine outfalls of São Sebastião Channel, São Paulo state, Brazil. Marine Pollution Bulletin, v. 60, n. 4, p. 536-553, 2010.

TINOCO, I. M. Introdução ao estudo dos componentes bióticos dos sedimentos marinhos recentes. Recife: Universitária da UFPE, 1988. 220p.

VALERIO, F.; PICCARDO, M. T. \& GRASSO, E. Precision of Benzo (a) pyrene (BaP) analysis in mussel tissue. Marine Pollution Bulletin, v. 40,n. 6, p. 551- 554, 2000.

WALTON, W. R. Techniques for recognition of living foraminifera. Contribution of Cushman foundation for Foraminiferal Research, v. 3, p. 56-60, 1952.

WALTON, W. R. \& SLOAN, B. J. The genus Ammonia Brünnich, 1722: its geographic distribution and morphologic variability. Journal of Foraminifera Research, v. 20, n. 2, p. 128-136, 1990.

WEBER, R. R. Sistemas costeiros e oceânicos. Química Nova, v. 15, n. 2, p. 137-143, 1992.

WENTHWORTH, C. K. A scale of grade and class terms for clastics sediments. Journal of Geology, v. 30, p.377-392, 1922.

WERME, C.; HUNT, C. D. Outfall monitoring overview. Boston: Massachusetts Water Resources Authority. 2004. Report 13. 97 p.

YANG, LEI; CHANG, W-S.; LO HUANG, M-N. Natural desinfection of wastewater in marine outfall fields. Water Research, v. 34, n. 3, p. 743-750, 2000.

YANKO, V.; KRONFELD, J.; FLEXER, A. Response of benthic foraminifera to various pollution sources: implications for pollution monitoring. Journal of Foraminiferal Research, v. 24, n. 1, p. 1-17, 1994.

ZALESNY, E. M. Foraminiferal ecology of Santa Monica Bay, California. Micropaleontolgy, v. 5, n. 1, p. 101-126, 1959.

ZANARDI, E.; BÍCEGO, M. C.; MIRANDA, L. B.; WEBER, R. R. Distribution and origino $f$ hydrocarbons in the water and sediment in São Sebastião, SP, Brazil. Marine Pollution Bulletin, v. 38, n. 4, p. 261-267, 1999a.

ZANARDI, E.; BÍCEGO, M. C.; WEBER, R. R. Dissolved/dispersed petroleum aromatic hydrocarbons in the São Sebastião Channel, São Paulo, Brazil. Marine Pollution Bulletin, v. 38, n. 5, p. 410-413, 1999. 
10. ANEXO

Anexo 01- Parâmetros físico-químicos da coluna d'água dos pontos amostrais de 2006. Os dados em rosa estão abaixo do estipulado pelo CONAMA.

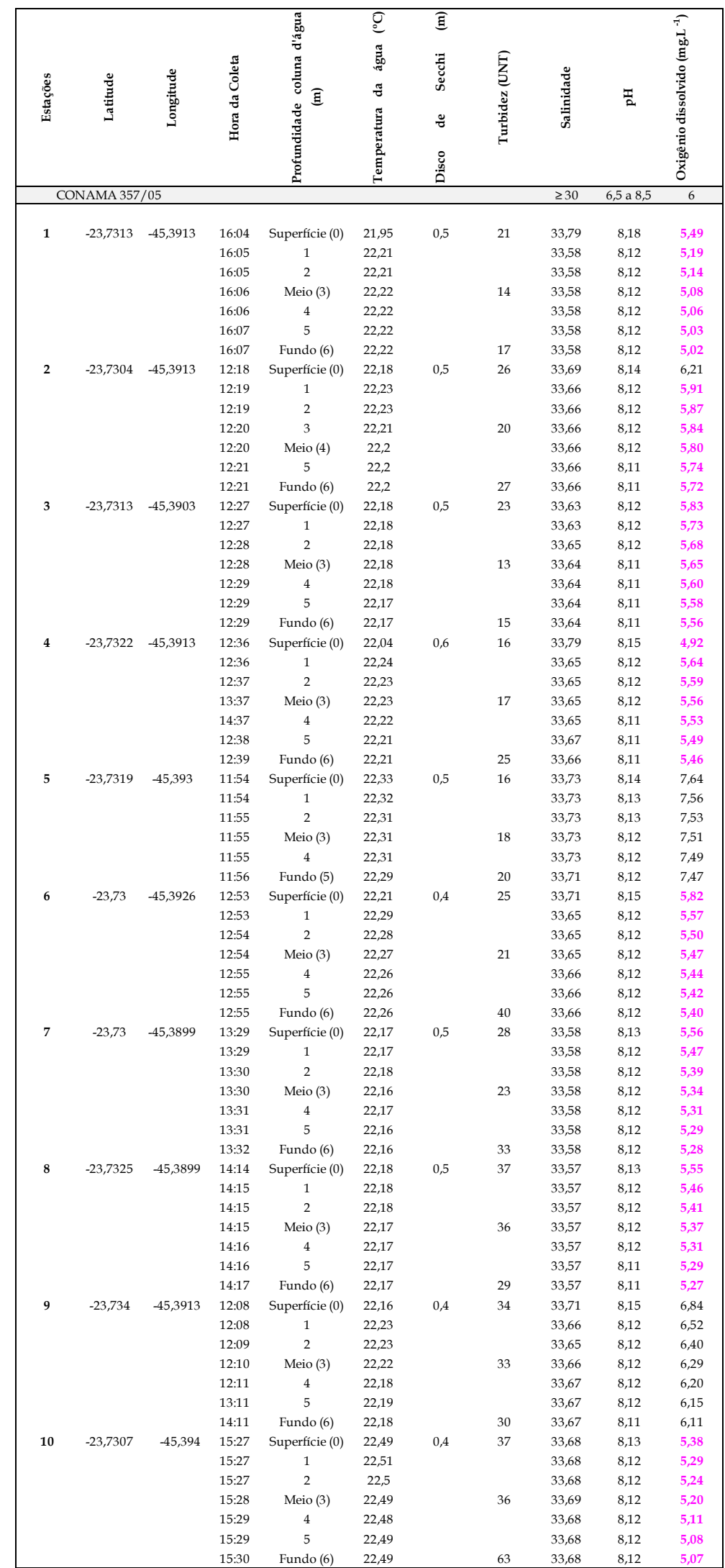


Anexo 02- Frequência relativa dos foraminíferos mortos e vivos encontrados nos sedimentos de 2006.

\begin{tabular}{|c|c|c|c|c|c|c|c|c|c|c|c|c|c|c|c|c|c|c|c|c|}
\hline Estação & 1 & 1 & & 2 & 3 & 3 & 3 & 4 & & 5 & t & 6 & 2 & 7 & 8 & & s & 9 & 1 & 10 \\
\hline $\mathrm{M}=$ mortos; $\mathrm{V}=$ vivos & $\% \mathbf{M}$ & $\% \mathrm{~V}$ & $\% \mathbf{M}$ & $\% \mathrm{~V}$ & $\% \mathbf{M}$ & $\% \mathrm{~V}$ & $\% \mathbf{M}$ & $\% \mathrm{~V}$ & $\% \mathbf{M}$ & $\% \mathrm{~V}$ & $\% \mathbf{M}$ & $\% \mathrm{~V}$ & $\% \mathbf{M}$ & $\% \mathrm{~V}$ & $\% \mathbf{M}$ & $\% \mathrm{~V}$ & $\% \mathbf{M}$ & $\% \mathrm{~V}$ & $\% \mathbf{M}$ & $\% \mathrm{~V}$ \\
\hline fração $0.062 \mathrm{~mm}$ (quarteamento) & $1 / 4$ & 1 & $1 / 2$ & 1 & $1 / 4$ & 1 & $1 / 4$ & 1 & $1 / 2$ & 1 & $1 / 4$ & 1 & $1 / 4$ & 1 & $1 / 4$ & 1 & $1 / 2$ & 1 & $1 / 4$ & 1 \\
\hline Total analisado & 341 & 110 & 346 & 131 & 300 & 100 & 316 & 215 & 300 & 102 & 300 & 114 & 342 & 100 & 300 & 164 & 304 & 146 & 302 & 153 \\
\hline indivíduos. $\mathrm{cc}^{-1}$ & $1364 / 10$ & $110 / 10$ & $692 / 10$ & $131 / 20$ & $1200 / 10$ & $100 / 10$ & $1264 / 10$ & $215 / 10$ & $600 / 10$ & $102 / 10$ & $1200 / 10$ & $114 / 10$ & $1368 / 10$ & $100 / 10$ & $1200 / 10$ & $164 / 20$ & $608 / 10$ & $146 / 20$ & $1208 / 10$ & $153 / 10$ \\
\hline indivíduos. $10 \mathrm{cc}^{-1}$ & 1364 & 110 & 692 & 65 & 1200 & 100 & 1264 & 215 & 600 & 102 & 1200 & 114 & 1368 & 100 & 1200 & 82 & 608 & 73 & 1208 & 153 \\
\hline $\mathbf{n}^{\circ}$ de espécies & 21 & 8 & 17 & 8 & 21 & 7 & 15 & 14 & 17 & 8 & 21 & 4 & 21 & 14 & 21 & 12 & 19 & 11 & 18 & 11 \\
\hline Diversidade de Shannon (H') & 2,49 & 1,04 & 2,16 & 1,50 & 2,45 & 1,50 & 2,10 & 1,52 & 1,93 & 1,28 & 2,12 & 1,09 & 2,43 & 1,73 & 2,60 & 1,34 & 2,30 & 1,49 & 2,16 & 1,50 \\
\hline Equitatividade de Shannon $\left(\mathrm{E}_{\mathrm{H}}\right)$ & 0,82 & 0,50 & 0,76 & 0,72 & 0,80 & 0,77 & 0,78 & 0,58 & 0,68 & 0,62 & 0,70 & 0,79 & 0,80 & 0,66 & 0,85 & 0,54 & 0,78 & 0,62 & 0,75 & 0,63 \\
\hline Ammonia parkinsoniana & 11,1 & 9,1 & 18,2 & 25,2 & 19,3 & 10,2 & 14,2 & 24,2 & 20,0 & 29,4 & 18,1 & 22,8 & 16,4 & 25,5 & 12,7 & 20,7 & 13,5 & 26,0 & 9,5 & 33,3 \\
\hline Ammonia tepida & 32,3 & 76,4 & 34,7 & 53,4 & 23,1 & 60,2 & 35,8 & 54,4 & 43,3 & 55,9 & 36,8 & 64,9 & 32,2 & 48,0 & 21,7 & 60,4 & 31,6 & 54,1 & 38,5 & 47,1 \\
\hline Ammonia sp. & 0,6 & 0,9 & 1,2 & 6,9 & 1,0 & 2,0 & 0,0 & 1,9 & 1,7 & 3,9 & 0,3 & 1,8 & 0,9 & 1,0 & 2,7 & 0,0 & 1,0 & 3,4 & 3,5 & 1,3 \\
\hline Ammonia sp. juvenil & 0,6 & 1,8 & 0,0 & 0,0 & 0,0 & 0,0 & 0,0 & 0,0 & 0,0 & 0,0 & 0,0 & 0,0 & 0,0 & 0,0 & 0,3 & 0,0 & 0,3 & 0,0 & 4,2 & 0,0 \\
\hline Ammoscalaria sp. & 0,0 & 0,0 & 0,0 & 0,0 & 0,0 & 0,0 & 0,0 & 0,0 & 0,0 & 0,0 & 0,0 & 0,0 & 0,3 & 0,0 & 0,7 & 0,0 & 0,0 & 0,0 & 0,4 & 0,0 \\
\hline Ammotium salsum & 0,0 & 0,0 & 0,0 & 0,0 & 0,0 & 0,0 & 0,0 & 0,0 & 0,0 & 0,0 & 0,0 & 0,0 & 0,0 & 0,0 & 0,0 & 0,0 & 0,0 & 0,7 & 0,0 & 0,0 \\
\hline Bolivina compacta & 0,9 & 0,9 & 0,6 & 1,5 & 0,0 & 0,0 & 0,0 & 0,0 & 0,0 & 0,0 & 0,0 & 0,0 & 0,0 & 1,0 & 0,0 & 1,2 & 0,0 & 0,7 & 0,0 & 0,0 \\
\hline Bolivina danvillensis & 0,0 & 0,0 & 0,0 & 0,0 & 0,0 & 0,0 & 0,0 & 0,5 & 0,0 & 0,0 & 0,0 & 0,0 & 0,0 & 0,0 & 1,0 & 0,0 & 0,0 & 0,0 & 0,4 & 0,0 \\
\hline Bolivina doniezi & 1,2 & 0,0 & 0,0 & 1,5 & 0,7 & 0,0 & 0,0 & 0,9 & 1,0 & 1,0 & 0,0 & 0,0 & 0,3 & 1,0 & 0,7 & 1,2 & 0,0 & 1,4 & 0,4 & 0,7 \\
\hline Bolivina ordinaria & 1,8 & 1,8 & 0,0 & 2,3 & 0,7 & 0,0 & 0,6 & 2,3 & 0,3 & 0,0 & 0,3 & 0,0 & 0,3 & 1,0 & 0,3 & 0,0 & 1,0 & 2,1 & 0,4 & 0,0 \\
\hline Bolivina pulchella & 5,0 & 0,0 & 3,8 & 0,0 & 2,7 & 0,0 & 2,2 & 0,0 & 3,7 & 0,0 & 1,3 & 0,0 & 2,0 & 0,0 & 2,7 & 0,0 & 3,3 & 0,0 & 1,4 & 0,0 \\
\hline Bolivina sp. & 1,5 & 0,9 & 0,6 & 0,8 & 0,0 & 5,1 & 0,6 & 0,0 & 0,0 & 0,0 & 1,0 & 0,9 & 0,6 & 1,0 & 0,3 & 0,0 & 1,0 & 0,7 & 0,4 & 0,0 \\
\hline Brizalina striatula & 2,1 & 2,7 & 1,4 & 0,8 & 1,0 & 9,2 & 1,3 & 5,1 & 1,0 & 1,0 & 0,0 & 1,8 & 0,6 & 5,1 & 0,7 & 4,9 & 1,3 & 2,7 & 0,4 & 0,7 \\
\hline Buccela peruviana f. campsi & 0,0 & 0,0 & 0,0 & 0,0 & 0,3 & 0,0 & 0,0 & 0,0 & 0,0 & 0,0 & 0,0 & 0,0 & 0,3 & 0,0 & 0,0 & 0,0 & 0,0 & 0,0 & 0,0 & 0,0 \\
\hline Bulimina marginata & 1,8 & 0,0 & 2,0 & 0,0 & 3,1 & 0,0 & 1,9 & 0,0 & 1,7 & 0,0 & 1,0 & 0,0 & 1,5 & 2,0 & 2,3 & 0,0 & 2,3 & 0,0 & 1,4 & 0,7 \\
\hline Bulimina pupoides & 0,3 & 0,0 & 0,0 & 0,0 & 1,0 & 0,0 & 0,0 & 0,0 & 0,7 & 0,0 & 0,0 & 0,0 & 0,0 & 0,0 & 0,0 & 0,0 & 0,0 & 0,0 & 0,0 & 0,0 \\
\hline Bulimina sp. & 0,6 & 0,0 & 0,6 & 0,0 & 0,3 & 0,0 & 0,0 & 0,0 & 0,0 & 0,0 & 0,0 & 0,0 & 0,6 & 0,0 & 0,3 & 0,0 & 0,3 & 0,0 & 0,0 & 0,0 \\
\hline Buliminella elegantissima & 0,9 & 1,8 & 0,0 & 1,5 & 1,0 & 4,1 & 0,6 & 3,3 & 0,0 & 0,0 & 2,3 & 0,9 & 1,2 & 1,0 & 3,0 & 2,4 & 1,0 & 1,4 & 1,4 & 4,6 \\
\hline Cassidulina crassa forma media & 0,9 & 0,0 & 1,2 & 0,0 & 1,0 & 0,0 & 0,9 & 0,9 & 0,3 & 0,0 & 0,7 & 0,0 & 0,6 & 1,0 & 1,0 & 0,0 & 0,3 & 0,7 & 1,1 & 0,0 \\
\hline Cassidulina laevigata & 0,0 & 0,0 & 0,3 & 0,0 & 0,0 & 0,0 & 0,0 & 0,0 & 0,0 & 0,0 & 0,0 & 0,0 & 0,0 & 0,0 & 0,0 & 0,0 & 0,3 & 0,0 & 0,0 & 0,0 \\
\hline Cassidulina minuta & 0,0 & 0,0 & 0,0 & 0,0 & 0,0 & 0,0 & 0,0 & 0,0 & 0,0 & 0,0 & 0,3 & 0,0 & 0,0 & 0,0 & 0,0 & 0,0 & 0,0 & 0,0 & 0,0 & 0,0 \\
\hline Cassidulina subglobosa & 0,0 & 0,0 & 0,0 & 0,0 & 0,0 & 0,0 & 0,0 & 0,0 & 0,0 & 0,0 & 0,0 & 0,0 & 0,3 & 0,0 & 0,0 & 0,0 & 0,0 & 0,0 & 0,4 & 0,0 \\
\hline Cassidulina sp. & 0,0 & 0,0 & 0,3 & 0,0 & 0,0 & 0,0 & 0,0 & 0,0 & 0,0 & 0,0 & 0,3 & 0,0 & 0,0 & 0,0 & 0,0 & 0,0 & 0,3 & 0,0 & 0,0 & 0,0 \\
\hline Cribroelphidium advenum & 1,8 & 0,0 & 0,0 & 0,0 & 2,4 & 0,0 & 1,3 & 0,0 & 1,0 & 0,0 & 1,0 & 0,0 & 1,5 & 1,0 & 2,3 & 0,6 & 1,3 & 0,0 & 0,7 & 0,7 \\
\hline Cribroelphidium discoidale & 1,5 & 0,0 & 2,0 & 0,8 & 2,4 & 0,0 & 1,3 & 0,0 & 0,3 & 0,0 & 0,3 & 0,0 & 1,5 & 0,0 & 0,7 & 0,0 & 0,7 & 0,0 & 0,0 & 0,0 \\
\hline Cribroelphidium excavatum & 2,9 & 0,0 & 0,6 & 0,0 & 2,4 & 0,0 & 6,0 & 0,0 & 1,3 & 0,0 & 1,0 & 0,0 & 4,1 & 0,0 & 3,0 & 0,0 & 2,0 & 0,0 & 1,8 & 1,3 \\
\hline Cribroelphidium gunteri & 0,0 & 0,0 & 0,3 & 0,0 & 0,0 & 0,0 & 0,0 & 0,0 & 2,0 & 0,0 & 1,0 & 0,0 & 2,3 & 1,0 & 0,7 & 0,0 & 0,7 & 0,0 & 0,0 & 0,0 \\
\hline Cribroelphidium poyeanum & 3,5 & 0,0 & 3,2 & 0,0 & 5,4 & 1,0 & 7,3 & 1,9 & 1,3 & 1,0 & 3,7 & 0,0 & 2,9 & 3,1 & 2,7 & 0,6 & 3,3 & 0,0 & 3,2 & 2,6 \\
\hline Cribroelphidium sp. & 0,6 & 0,0 & 1,7 & 0,0 & 1,4 & 0,0 & 1,9 & 0,0 & 0,7 & 1,0 & 1,3 & 1,8 & 2,3 & 1,0 & 3,0 & 0,0 & 2,0 & 0,0 & 2,5 & 0,7 \\
\hline Cribroelphidium sp. juvenil & 0,9 & 0,9 & 1,2 & 0,8 & 0,3 & 0,0 & 0,6 & 0,0 & 0,3 & 1,0 & 0,0 & 0,9 & 2,6 & 0,0 & 1,0 & 0,0 & 1,3 & 0,0 & 0,7 & 0,7 \\
\hline Cribrostomoides sp. & 0,3 & 0,0 & 0,0 & 1,5 & 0,0 & 2,0 & 0,0 & 0,5 & 0,0 & 0,0 & 0,0 & 0,0 & 0,6 & 0,0 & 1,0 & 0,0 & 0,0 & 0,0 & 0,0 & 0,0 \\
\hline Cyclogyra planorbis & 0,0 & 0,9 & 0,0 & 0,0 & 0,0 & 0,0 & 0,0 & 0,0 & 0,0 & 0,0 & 0,0 & 0,0 & 0,0 & 0,0 & 0,0 & 0,0 & 0,0 & 0,0 & 0,0 & 0,0 \\
\hline Discorbis williamsoni & 0,0 & 0,0 & 0,0 & 0,0 & 0,0 & 0,0 & 0,0 & 0,0 & 0,0 & 0,0 & 0,0 & 0,0 & 0,3 & 0,0 & 0,0 & 0,0 & 0,0 & 0,0 & 0,0 & 0,0 \\
\hline Fissurina laevigata & 0,0 & 0,0 & 0,0 & 0,0 & 0,3 & 0,0 & 0,0 & 0,0 & 0,0 & 0,0 & 0,3 & 0,0 & 0,3 & 0,0 & 1,0 & 0,6 & 0,0 & 0,0 & 0,0 & 0,0 \\
\hline Fissurina sp. & 0,3 & 0,0 & 0,0 & 0,0 & 0,0 & 0,0 & 0,0 & 0,0 & 0,0 & 0,0 & 0,3 & 0,0 & 0,0 & 0,0 & 0,0 & 0,0 & 0,0 & 0,0 & 0,0 & 0,0 \\
\hline Funserkoina pontoni & 0,0 & 0,0 & 0,6 & 0,0 & 0,0 & 0,0 & 0,0 & 0,0 & 0,0 & 0,0 & 0,0 & 0,0 & 0,0 & 0,0 & 0,0 & 0,0 & 0,0 & 0,0 & 0,0 & 0,0 \\
\hline Hanzawaia boueana & 0, & 0,0 & 0,0 & 0,0 & 0,3 & & 0,0 & 0,0 & 0,0 & 0,0 & 0,7 & 0,0 & 0,0 & 0,0 & 0,7 & 0,0 & 1,0 & 0,0 & 0,0 & 0,0 \\
\hline Hopkinsina pacifica & 0,0 & 0,0 & 0,0 & 0,0 & 0,0 & 0,0 & 0,0 & 0,0 & 0,0 & 0 & 0,3 & 0,0 & 0,0 & 0,0 & 0,0 & 0,6 & 0,0 & 0,0 & 0,0 & 0,0 \\
\hline Lagena caudata & 0,0 & 0,0 & 0,0 & 0,0 & 0,0 & 2,0 & 0,0 & 0,5 & 0,0 & 0,0 & 0,0 & 0,0 & 0,0 & 1,0 & 0,3 & 0,0 & 0,0 & 0,0 & 0,0 & 0,0 \\
\hline Lagena laevis & 0,0 & 0,0 & 0,0 & 0,0 & 0,3 & 0 & 0,0 & 0,0 & 0,0 & 0,0 & 0,0 & 0,0 & 0,0 & 0,0 & 0,0 & 0,0 & 0,0 & 0,0 & 0,0 & 0,0 \\
\hline Lagena striata & 0,0 & 0,9 & 0,0 & 0,0 & 0,0 & 0,0 & 0,0 & 0,0 & 0,0 & 0,0 & 0,0 & 0,0 & 0,0 & 0,0 & 0,0 & 0,0 & 0,0 & 0,0 & 0,4 & 0,0 \\
\hline Lagena sp. & 0,0 & 0,0 & 0,3 & 0,0 & 0,0 & 0,0 & 0,0 & 0,0 & 0,0 & 0,0 & 0,0 & 0,0 & 0,0 & 0,0 & 0,0 & 0,0 & 0,0 & 0,7 & 0,0 & 0,0 \\
\hline Lenticulina sp. & 0,0 & 0,0 & 0,0 & 0 & 0,0 & 0,0 & 0,0 & 0,0 & 0,0 & & 0,0 & 0,0 & 0,0 & 0,0 & 0,0 & 0,0 & 0,0 & 0,0 & 0,0 & 0,0 \\
\hline Neocornobina terquemi & 0,3 & 0,0 & 0,3 & 0,0 & 0,0 & 0,0 & 0,0 & 0,0 & 0,0 & 0,0 & 0,3 & 0,0 & 0,0 & 0,0 & 0,0 & 0,0 & 0,0 & 1,4 & 0,4 & 0,0 \\
\hline Pararotalia cananeiaensis & 15,8 & 0,0 & 18,2 & 0,0 & 19,0 & 0,0 & 18,0 & 0,5 & 13,3 & 1,0 & 18,1 & 0,0 & 14,3 & 0,0 & 24,0 & 0,6 & 21,7 & 0,0 & 20,8 & 1,3 \\
\hline Pseudononion atlanticum & 5,3 & 0,0 & 2,6 & 0,0 & 1,7 & 1,0 & 2,2 & 0,9 & 1,0 & 1,0 & 2,0 & 0,0 & 2,9 & 1,0 & 3,0 & 0,6 & 3,3 & 0,7 & 1,1 & 0,7 \\
\hline Pseudononion sp. & 0,0 & 0,0 & 0 & 0 & 2,4 & & 0 & & 0,7 & 0,0 & 0,0 & 0,0 & 0,0 & 0,0 & 1,3 & 0,0 & 0,7 & 0,7 & 1,1 & 0,0 \\
\hline Quinqueloculina patagonica & 0,0 & 0,0 & 0,0 & 0 & 0,0 & 0,0 & 0,0 & 0,0 & 0,0 & 0,0 & 0,0 & 0,0 & 0,0 & 0,0 & 0,0 & 0,0 & 0,3 & 0,0 & 0,0 & 0,0 \\
\hline Quinqueloculina sp. & 0,0 & 0,9 & 0,3 & 0,0 & 0,0 & 2,0 & 0,0 & 0,5 & 0,0 & 0,0 & 0,7 & 0,0 & 0,3 & 0,0 & 0,0 & 0,0 & 0,0 & 0,0 & 0,0 & 0,0 \\
\hline Rolshauseni rolshauseni & 1,8 & 0,0 & 0,9 & 0,0 & 3,1 & 0,0 & 0,9 & 0,5 & 2,0 & 1,0 & 1,3 & 0,0 & 2,0 & 0,0 & 0,0 & 0,0 & 0,3 & 0,0 & 0,0 & 0,0 \\
\hline Textularia earlandi & 0,0 & 0,0 & 0,0 & 0,0 & 0,0 & 0,0 & 0,0 & 0,5 & 0,0 & 0,0 & 0,0 & 0,0 & 0,6 & 0,0 & 1,0 & 0,0 & 0,0 & 0,0 & 0,0 & 0,0 \\
\hline Textularia sp. & 0,0 & 0,0 & 0,0 & 0,0 & 0,0 & 0,0 & 0,0 & 0,0 & 0,0 & 0,0 & 0,0 & 0,0 & 0,0 & 0,0 & 0,0 & 0,0 & 0,0 & 0,0 & 0,0 & 0,7 \\
\hline Triloculina sp. & 0,0 & 0,0 & 0,0 & 0,0 & 0,0 & 0,0 & 0,0 & 0,0 & 0,0 & 0,0 & 0,3 & 0,0 & 0,0 & 0,0 & 0,0 & 0,0 & 0,0 & 0,0 & 0,0 & 0,0 \\
\hline Uvigerina peregrina & 0,3 & 0,0 & 0,0 & 0,0 & 0,0 & 0,0 & 0,0 & 0,0 & 0,0 & 0,0 & 0,3 & 0,0 & 0,0 & 0,0 & 0,0 & 0,0 & 0,0 & 0,0 & 0,0 & 0,0 \\
\hline Indeterminado & 2,3 & 0,0 & 3,2 & 1,5 & 3,4 & 0,0 & 2,2 & 0,9 & 2,3 & 2,9 & 4,3 & 4,4 & 3,2 & 4,1 & 3,0 & 4,9 & 3,9 & 2,7 & 3,5 & 3,3 \\
\hline Aglutinante indeterminado & 0,3 & 0,0 & 0,0 & 0,8 & 0,0 & 0,0 & 0,0 & 0,0 & 0,0 & 0,0 & 0,0 & 0,0 & 0,3 & 0,0 & 1,0 & 0,6 & 0,0 & 0,0 & 0,4 & 0,0 \\
\hline
\end{tabular}


Anexo 03- Parâmetros físico-químicos da coluna d'água dos pontos amostrais de 2007.

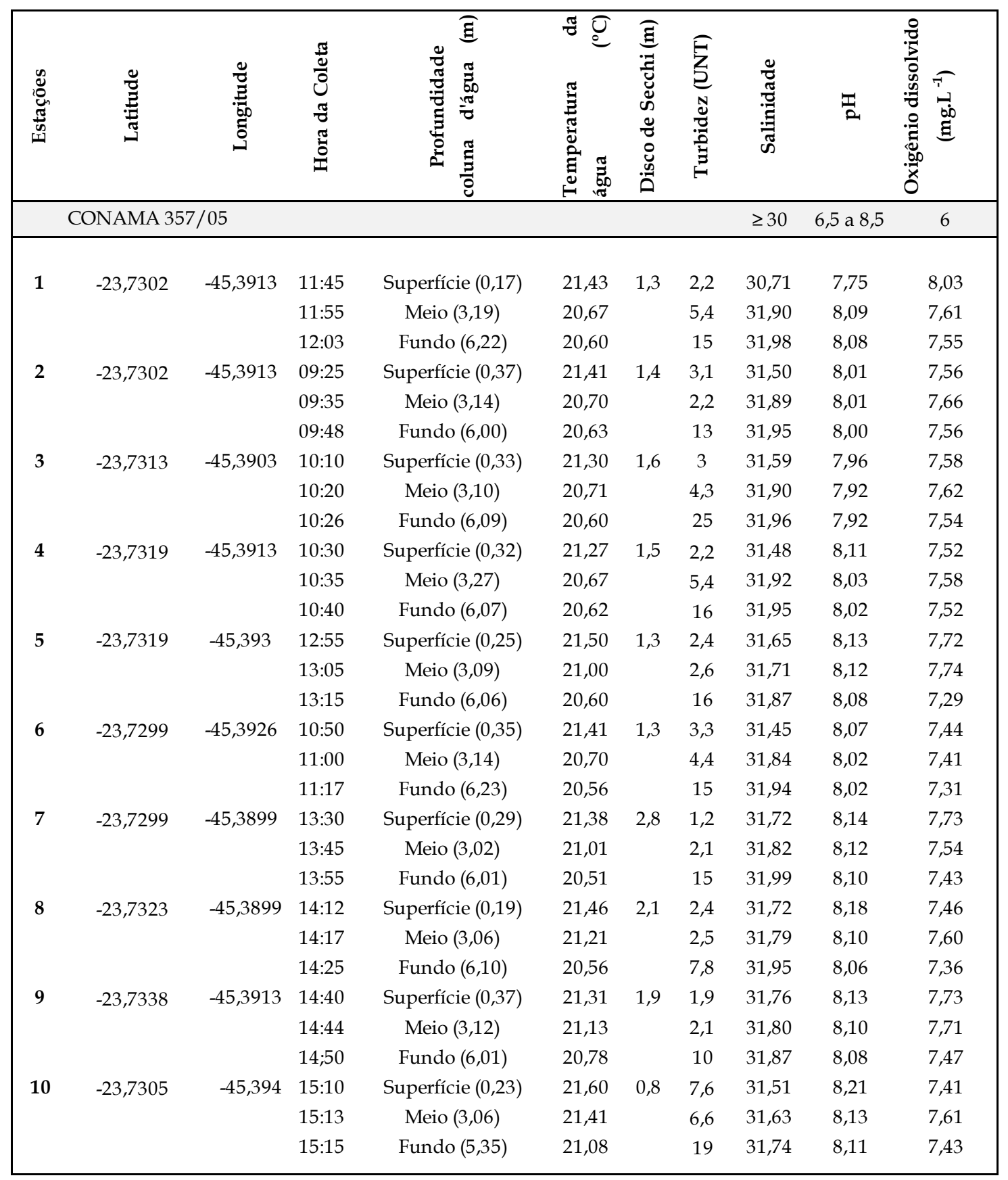


Anexo 04- Frequência relativa dos foraminíferos mortos e vivos encontrados nos sedimentos de 2007.

\begin{tabular}{|c|c|c|c|c|c|c|c|c|c|c|c|c|c|c|c|c|c|c|c|c|}
\hline Estação & 1 & 1 & 2 & & $3^{3}$ & 3 & 4 & 4 & 5 & & & & 72 & & 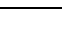 & 8 & te & & 1 & \\
\hline $\mathrm{M}=$ mortos; $\mathrm{V}=$ vivos & $\% \mathbf{M}$ & $\% \mathrm{~V}$ & $\% \mathrm{M}$ & $\% \mathrm{~V}$ & $\% \mathbf{M}$ & $\% \mathrm{~V}$ & $\% \mathrm{M}$ & $\% \mathrm{~V}$ & $\% \mathbf{M}$ & $\% \mathrm{~V}$ & $\% \mathbf{M}$ & $\% \mathrm{~V}$ & $\% \mathbf{M}$ & $\% \mathrm{~V}$ & $\% \mathbf{M}$ & $\% \mathrm{~V}$ & $\% \mathrm{M}$ & $\% \mathrm{~V}$ & $\% \mathbf{M}$ & $\% \mathrm{~V}$ \\
\hline fração $0.062 \mathrm{~mm}$ (quarteamento) & $1 / 4$ & 1 & $1 / 4$ & 1 & $1 / 4$ & 1 & $1 / 2$ & 1 & $1 / 4$ & 1 & $1 / 2$ & 1 & $1 / 4$ & 1 & $1 / 2$ & 1 & $1 / 4$ & 1 & 1 & 1 \\
\hline Total analisado & 300 & 101 & 368 & 250 & 329 & 108 & 353 & 114 & 302 & 127 & 340 & 100 & 327 & 105 & 339 & 128 & 311 & 121 & 315 & 177 \\
\hline indivíduos. $\mathrm{cc}^{-1}$ & $1200 / 10$ & $101 / 10$ & $1472 / 10$ & $250 / 10$ & $1316 / 10$ & $108 / 10$ & $706 / 10$ & $114 / 10$ & $1208 / 10$ & $127 / 10$ & $680 / 10$ & $100 / 10$ & $1308 / 10$ & $105 / 10$ & $678 / 10$ & $128 / 10$ & $1244 / 10$ & $121 / 10$ & $315 / 10$ & $177 / 20$ \\
\hline indivíduos. $10 \mathrm{cc}^{-1}$ & 1200 & 101 & 1472 & 250 & 1316 & 108 & 706 & 114 & 1208 & 127 & 680 & 100 & 1308 & 105 & 678 & 128 & 1244 & 121 & 315 & 85 \\
\hline$n^{\circ}$ de espécies & 20 & 10 & 27 & 16 & 23 & 12 & 19 & 8 & 21 & 11 & 22 & 10 & 23 & 14 & 25 & 12 & 21 & 8 & 19 & 12 \\
\hline Diversidade de Shannon (H') & 2,59 & 1,4 & 2,60 & 1,84 & 2,54 & 1,8 & 2,18 & 1,48 & 2,23 & 1,66 & 2,11 & 1,53 & 2,49 & 1,47 & 2,60 & 1,87 & 2,33 & 1,23 & 2,26 & 1,81 \\
\hline Equitatividade de Shannon $\left(\mathrm{E}_{\mathrm{H}^{\prime}}\right)$ & 0,86 & 0,61 & 0,79 & 0,66 & 0,81 & 0,72 & 0,74 & 0,71 & 0,73 & 0,69 & 0,68 & 0,66 & 0,79 & 0,56 & 0,81 & 0,75 & 0,77 & 0,59 & 0,77 & 0,73 \\
\hline Ammonia parkinsoniana & 13,6 & 35,6 & 10,3 & 23,2 & 16,7 & 26,9 & 16,7 & 26,3 & 20,5 & 28,3 & 18,5 & 24,0 & 10,4 & 25,7 & 13,0 & 21,1 & 18,0 & 29,8 & 14,3 & 29,4 \\
\hline Ammonia tepida & 25,2 & 45,5 & 24,7 & 45,6 & $\begin{array}{l}26,4 \\
26,4\end{array}$ & 44,4 & 34,8 & 50,0 & 30,5 & 46,5 & 31,5 & 54,0 & $\begin{array}{l}30,3 \\
30,3\end{array}$ & 54,3 & 26,8 & $\begin{array}{l}21,1 \\
43,8\end{array}$ & $\begin{array}{l}30,8 \\
33,8\end{array}$ & 57,0 & 29,5 & 41,2 \\
\hline Ammonia sp. & 0,7 & 0,0 & 0,3 & 0,0 & 0,3 & 0,0 & 0,0 & 0,0 & 0,3 & 0,0 & 0,3 & 0,0 & 0,0 & 0,0 & 0,3 & 0,0 & 0,0 & 0,8 & 1,0 & 1,1 \\
\hline Ammonia sp. juvenil & 0,3 & 0,0 & 0,0 & 0,0 & 0,6 & 0,0 & 0,0 & 0,0 & 1,0 & 0,0 & 0,6 & 1,0 & 0,9 & 0,0 & 0,0 & 0,0 & 0,0 & 0,0 & 2,9 & 0,0 \\
\hline Ammoscalaria sp. & 0,0 & 0,0 & 0,0 & 0,0 & 0,0 & 0,0 & 0,3 & 0,0 & 0,0 & 0,0 & 0,0 & 0,0 & 0,3 & 0,0 & 0,3 & 0,0 & 0,0 & 0,0 & 0,0 & 0,0 \\
\hline Ammotium salsum & 0,0 & 0,0 & 0,8 & 0,0 & 0,0 & 0,0 & 0,0 & 0,0 & 0,0 & 0,0 & 0,0 & 0,0 & 0,0 & 1,0 & 0,0 & 0,0 & 0,0 & 0,0 & 0,0 & 0,0 \\
\hline Bolivina compacta & 0,0 & 1,0 & 1,1 & 1,2 & 0,6 & 1,9 & 0,6 & 0,9 & 0,3 & 0,8 & 0,6 & 0,0 & 0,0 & 1,0 & 0,3 & 0,0 & 0,6 & 0,0 & 0,0 & 0,0 \\
\hline Bolivina danvillensis & 0,0 & 0,0 & 0,0 & 1,2 & 0,0 & 0,0 & 0,6 & 0,9 & 0,3 & 0,0 & 0,0 & 0,0 & 0,3 & 0,0 & 0,6 & 0,8 & 0,0 & 0,0 & 0,3 & 0,0 \\
\hline Bolivina doniezi & 3,4 & 1,0 & 1,6 & 3,2 & 0,9 & 2,8 & 0,0 & 0,9 & 1,0 & 2,4 & 0,3 & 1,0 & 0,6 & 0,0 & 1,2 & 1,6 & 0,3 & 0,8 & 0,6 & 0,0 \\
\hline Bolivina ordinaria & 0,7 & 1,0 & 0,0 & 2,4 & 0,0 & 4,6 & 0,0 & 0,0 & 0,0 & 3,1 & 0,9 & 2,0 & 0,6 & 2,9 & 1,5 & 1,6 & 1,0 & 1,7 & 1,9 & 0,0 \\
\hline Bolivina pulchella & 2,7 & 0,0 & 1,9 & 0,4 & 3,6 & 0,0 & 1,4 & 0,0 & 3,0 & 0,0 & 3,5 & 0,0 & 4,9 & 0,0 & 2,4 & 0,0 & 1,6 & 0,0 & 3,5 & 0,0 \\
\hline Bolivina sp. & 1,4 & 0,0 & 1,1 & 0,4 & 0,3 & 0,9 & 0,3 & 2,6 & 1,3 & 0,0 & 0,3 & 0,0 & 0,3 & 0,0 & 1,2 & 2,3 & 0,3 & 0,0 & 1,0 & 0,6 \\
\hline Brizalina striatula & 1,0 & 7,9 & 1,1 & 9,6 & 1,2 & 4,6 & 1,4 & 10,5 & 1,0 & 4,7 & 1,2 & 5,0 & 2,1 & 4,8 & 2,4 & 10,2 & 0,6 & 2,5 & 1,6 & 3,4 \\
\hline Buccela peruviana f. campsi & 0,7 & 0,0 & 0,5 & 0,0 & 0,3 & 0,0 & 0,0 & 0,0 & 0,0 & 0,0 & 0,0 & 0,0 & 0,0 & 0,0 & 0,9 & 0,0 & 0,0 & 0,0 & 0,0 & 0,0 \\
\hline $\begin{array}{l}\text { Bulimina marginata } \\
\text { Bumps }\end{array}$ & 2,4 & 0,0 & 1,4 & 0,4 & 3,3 & 0,0 & 2,8 & 0,0 & 1,7 & 0,0 & 2,6 & 0,0 & 3,4 & 0,0 & 2,7 & 0,0 & 3,0 & 1,7 & 0,3 & 0,6 \\
\hline Bulimina pupoides & 0,0 & 0,0 & 0,0 & 0,0 & 0,6 & 0,0 & 0,3 & 0,0 & 0,3 & 0,0 & 0,0 & 0,0 & 0,3 & 0,0 & 0,9 & 0,0 & 0,6 & 0,0 & 0,3 & 0,0 \\
\hline Bulimina sp. & 0,0 & 0,0 & 0,3 & 0,0 & 0,0 & 0,0 & 0,0 & 0,0 & 0,0 & 0,0 & 0,0 & 0,0 & 0,0 & 0,0 & 0,3 & 0,0 & 0,0 & 0,0 & 0,0 & 0,0 \\
\hline Buliminella elegantissima & 3,4 & 0,0 & 1,9 & 2,4 & 1,2 & 0,9 & 0,6 & 0,0 & 2,0 & 2,4 & 0,6 & 3,0 & 1,5 & 0,0 & 4,1 & 2,3 & 0,0 & 1,7 & 1,6 & 4,0 \\
\hline Cassidulina crassa forma media & 1,7 & 0,0 & 2,2 & 0,0 & 0,6 & 0,9 & 0,6 & 0,0 & 0,7 & $\begin{array}{l}2,+ \\
0,0\end{array}$ & 0,3 & 0,0 & 0,9 & 0,0 & $\begin{array}{l}1,1 \\
1,8\end{array}$ & 0,0 & 0,0 & 0,0 & 1,0 & 0,0 \\
\hline Cassidulina laevigata & 0,0 & 0,0 & 0,0 & 0,0 & 0,0 & 0,0 & 0,0 & 0,0 & 0,3 & 0,0 & 0,0 & 0,0 & 0,0 & 0,0 & 0,6 & 0,0 & 0,0 & 0,0 & 0,0 & 0,0 \\
\hline Cassidulina minuta & 0,0 & 0,0 & 0,3 & 0,0 & 0,3 & 0,0 & 0,0 & 0,0 & 0,0 & 0,0 & 0,0 & 0,0 & 0,0 & 0,0 & 0,0 & 0,0 & 0,6 & 0,0 & 0,3 & 0,0 \\
\hline Cassidulina subglobosa & 0,0 & 0,0 & 0,3 & 0,0 & 0,0 & 0,0 & 0,0 & 0,0 & 0,0 & 0,0 & 0,0 & 0,0 & 0,0 & 0,0 & 0,0 & 0,0 & 0,0 & 0,0 & 0,0 & 0,0 \\
\hline Cassidulina sp. & 0,0 & 0,0 & 0,0 & 0,0 & 0,0 & 0,0 & 0,0 & 0,0 & 0,0 & 0,0 & 0,0 & 0,0 & 0,6 & 0,0 & 0,0 & 0,0 & 0,3 & 0,0 & 1,0 & 0,6 \\
\hline Cribroelphidium advenum & 0,7 & 0,0 & 1,1 & 0,8 & 2,1 & 0,0 & 1,1 & 0,0 & 0,3 & 0,0 & 0,3 & 1,0 & 0,3 & 0,0 & 0,9 & 0,0 & 1,0 & 0,0 & 1,3 & 0,6 \\
\hline Cribroelphidium discoidale & 2,0 & 0,0 & 0,8 & 0,0 & 1,8 & 0,0 & 0,8 & 0,0 & 0,7 & 0,0 & 0,6 & 0,0 & 2,8 & 0,0 & 0,9 & 0,0 & 2,6 & 0,0 & 0,3 & 0,0 \\
\hline Cribroelphidium excavatum & 5,4 & 0,0 & 4,9 & 0,0 & 5,5 & 0,0 & 8,2 & 0,0 & 4,6 & 2,4 & 3,8 & 0,0 & 5,2 & 1,0 & 6,2 & 0,8 & 9,0 & 0,0 & 0,6 & 2,3 \\
\hline Cribroelphidium gunteri & 0,0 & 0,0 & 0,0 & 0,0 & 0,0 & 0,0 & 0,0 & 0,0 & 0,0 & 0,0 & 0,6 & 0,0 & 0,0 & 0,0 & 0,3 & 0,0 & 0,6 & 0,0 & 0,0 & 0,0 \\
\hline Cribroelphidium poyeanum & 4,8 & 0,0 & 5,4 & 0,4 & 4,0 & 0,0 & 5,4 & 0,0 & $\begin{array}{l}3,0 \\
3,0\end{array}$ & 0,8 & 3,5 & 2,0 & 7,0 & 1,0 & 1,2 & 0,0 & 3,5 & 0,0 & 3,8 & 0,0 \\
\hline $\begin{array}{l}\text { Cribroelphidium sp. } \\
\text { spent }\end{array}$ & 3,1 & 1,0 & 1,9 & 0,0 & 1,5 & 0,0 & 1,4 & 0,0 & 1,0 & 0,8 & 0,0 & 1,0 & 0,6 & 0,0 & 1,2 & 0,0 & 2,3 & 1,7 & 1,6 & 0,0 \\
\hline Cribroelphidium sp. juvenil & 0,0 & 0,0 & 0,0 & 0,0 & 0,0 & 0,0 & 0,0 & 1,8 & 0,0 & 0,0 & 0,6 & 1,0 & 0,0 & 0,0 & 0,6 & 0,0 & 0,0 & 0,0 & 0,0 & 2,3 \\
\hline Cribrostomoides sp. & 0,3 & 1,0 & 0,3 & 0,8 & 0,3 & 2,8 & 0,0 & 2,6 & 0,0 & 0,8 & 0,3 & 1,0 & 0,0 & 1,0 & 1,2 & 2,3 & 0,0 & 0,0 & 0,0 & 0,0 \\
\hline Discorbis bertheloti & 0,0 & 0,0 & 0,0 & 0,4 & 0,0 & 0,0 & 0,0 & 0,0 & 0,0 & 0,0 & 0,9 & 0,0 & 0,0 & 0,0 & 0,0 & 0,0 & 0,0 & 0,0 & 0,0 & 0,0 \\
\hline $\begin{array}{l}\text { Discorbis williamsoni } \\
\text { D. }\end{array}$ & 0,0 & 0,0 & 0,0 & $\begin{array}{l}0,4 \\
0,0\end{array}$ & 0,0 & 0,0 & 0,0 & 0,0 & 0,0 & 0,0 & 0,0 & 0,0 & 0,0 & 0,0 & 0,0 & 0,0 & 0,0 & 0,0 & 0,3 & 0,0 \\
\hline Fissurina laevigata & 0,3 & 0,0 & 0,0 & 0,0 & 0,0 & 0,0 & 0,3 & 0,0 & 0,0 & 0,0 & 0,0 & 0,0 & 0,9 & 0,0 & 0,0 & 0,0 & 0,0 & 0,0 & 0,0 & 0,0 \\
\hline Funserkoina pontoni & 0,0 & 0,0 & 0,3 & 0,0 & 0,0 & 0,9 & 0,0 & 0,0 & 0,0 & 0,0 & 0,0 & 0,0 & 0,0 & 1,0 & 0,3 & 0,0 & 0,3 & 0,0 & 0,0 & 0,6 \\
\hline Hanzawaaia boueana & 0,3 & 0,0 & 1,1 & 0,0 & 1,2 & 0,0 & 1,1 & 0,0 & 0,3 & 0,0 & 0,3 & 0,0 & 0,9 & 0,0 & 0,0 & 0,0 & 0,6 & 0,0 & 0,0 & 0,0 \\
\hline Hopkinsina pacifica & 0,0 & 2,0 & $\begin{array}{l}1,1 \\
0,0\end{array}$ & 0,4 & $\begin{array}{l}1,2 \\
0,0\end{array}$ & 1,9 & $\begin{array}{l}1,1 \\
0,0\end{array}$ & 0,0 & 0,0 & 0,0 & 0,0 & 0,0 & 0,0 & 0,0 & 0,3 & 1,6 & 0,0 & 0,0 & 0,0 & 0,6 \\
\hline $\begin{array}{l}\text { Hophinsinella sp.ce. } \\
\text { Hopkins. }\end{array}$ & 0,0 & $\begin{array}{l}2,0 \\
0,0\end{array}$ & 0,0 & $\begin{array}{l}0,4 \\
0,0\end{array}$ & 0 & 0,0 & 0,0 & 0,0 & 0,0 & 0,0 & 0,0 & 0,0 & 0,0 & 0,0 & 0,0 & $\begin{array}{l}1,0 \\
0,8\end{array}$ & 0,0 & 0,0 & 0,0 & $\begin{array}{l}0,0 \\
0,0\end{array}$ \\
\hline Lagena caudata & 0,0 & 0,0 & 0,0 & 0,0 & 0,0 & 0,0 & 0,0 & 0,0 & 0,0 & 0,0 & 0,3 & 0,0 & 0,0 & 0,0 & 0,0 & 0,0 & 0,0 & 0,0 & 0,0 & 0,0 \\
\hline Lagena striata & 0,0 & 0,0 & 0,0 & 0,0 & 0,0 & 0,0 & 0,0 & 0,0 & 0,0 & 0,0 & 0,3 & 0,0 & 0,0 & 0,0 & 0,0 & 0,0 & 0,0 & 0,0 & 0,0 & 0,0 \\
\hline 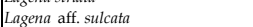 & 0,0 & 0,0 & 0,3 & 0,0 & 0,3 & 0,0 & 0,0 & 0,0 & 0,0 & 0,0 & 0,0 & 0,0 & 0,0 & 1,0 & 0,0 & 0,0 & 0,0 & 0,0 & 0,0 & 0,0 \\
\hline Miliammina fusca & 0,0 & 1,0 & 0,3 & 0,4 & 0,0 & 0,0 & 0,0 & 0,0 & 0,0 & 0,0 & 0,0 & 0,0 & 0,3 & 0,0 & 0,3 & 0,0 & 0,3 & 0,0 & 0,0 & 0,0 \\
\hline Neocornobina terquemi & 0,0 & 2,0 & 0,0 & 0,8 & 0,3 & 0,9 & 0,0 & 0,0 & 0,0 & 0,8 & 0,3 & 0,0 & 0,0 & 0,0 & 0,0 & 0,0 & 0,0 & 0,0 & 0,0 & 0,0 \\
\hline Pararotalia cananeiaensis & 13,9 & 0,0 & 22,6 & 0,0 & 15,2 & 0,0 & 13,9 & 1,8 & 18,2 & 1,6 & 23,5 & 2,0 & 15,3 & 1,0 & 18,3 & 0,0 & 10,9 & 0,0 & 24,1 & 0,6 \\
\hline Pseudononion atlanticum & 1,7 & 1,0 & 2,4 & 0,8 & 3,0 & 0,9 & 3,4 & 0,9 & 3,6 & 0,0 & 0,3 & 1,0 & 3,4 & 2,9 & 1,8 & 3,1 & 1,0 & 0,0 & 2,5 & 5,1 \\
\hline $\begin{array}{l}\text { Pseudononion sp. } \\
\text { Psp. }\end{array}$ & 0,0 & 0, & $\begin{array}{l}2,4 \\
0,3\end{array}$ & 0,0 & $\begin{array}{l}0,0 \\
0,9\end{array}$ & 0 & $\begin{array}{l}\begin{array}{l}0,4 \\
0,0\end{array} \\
0\end{array}$ & 0,0 & $\begin{array}{l}0,0 \\
0,0\end{array}$ & 0,0 & 0,0 & 0,0 & $\begin{array}{l}0,4 \\
0,0\end{array}$ & 0,0 & 0,6 & $\begin{array}{l}0,1 \\
0,0\end{array}$ & 0,0 & 0,0 & 0,3 & $\begin{array}{l}0,1 \\
0,6\end{array}$ \\
\hline Quinqueloculina patagonica & 0,0 & 0,0 & 0,3 & 1,2 & 0,0 & 0,0 & 0,0 & 0,0 & 0,0 & 0,0 & 0,0 & 0,0 & 0,0 & 1,0 & 0,0 & 0,8 & 0,0 & 0,0 & 0,0 & 0,0 \\
\hline Quinqueloculina sp. & 0,3 & 0,0 & 0,3 & 1,2 & 0,0 & 0,9 & 0,0 & 0,9 & 0,0 & 1,6 & 0,0 & 0,0 & 0,0 & 0,0 & 0,0 & 0,0 & 1,0 & 0,0 & 0,3 & 0,6 \\
\hline Rolshauseni rolshauseni & 3,4 & 0,0 & 2,7 & 0,0 & 1,8 & 0,0 & 1,7 & 0,0 & 1,3 & 0,0 & 0,9 & 0,0 & 2,1 & 1,0 & 0,6 & 2,3 & 1,9 & 1,7 & 0,0 & 0,6 \\
\hline & 0,0 & 0, & 0,0 & 0,0 & 0, & & 0,0 & 0,0 & 0,0 & & 0,0 & 0,0 & 0,0 & 0,0 & 0,0 & 0,0 & 0,3 & 0,0 & 0,0 & 0,0 \\
\hline $\begin{array}{l}\text { Spextularia ag splutinans } \\
\text { Textan }\end{array}$ & 0,0 & 0,0 & 0,3 & 0,0 & 0, & 0 & 0,0 & 0,0 & 0 & 0,0 & 0,0 & 0,0 & 0,0 & 0,0 & 0,0 & 0,0 & 0,0 & 0,0 & 0,0 & 0,0 \\
\hline Textularia earlandi & 0,7 & 0,0 & 1,4 & 0,0 & 0,3 & 0,0 & 0,0 & 0,0 & 0,3 & 0,0 & 0,0 & 0,0 & 0,6 & 0,0 & 0,0 & 0,0 & 0,3 & 0,0 & 0,0 & 0,0 \\
\hline Textularia sp. & 0,0 & 0,0 & 0,0 & 0,0 & 0,3 & 0,0 & 0,0 & 0,0 & 0,0 & 0,0 & 0,0 & 0,0 & 0,0 & 0,0 & 0,0 & 0,0 & 0,3 & 0,0 & 0,0 & 0,0 \\
\hline Uvigerina peregrina & 0,0 & 0,0 & 0,0 & 0,0 & 0,0 & 0,0 & 0,0 & 0,0 & 0,0 & 0,0 & 0,0 & 0,0 & 0,3 & 0,0 & 0,0 & 0,0 & 0,0 & 0,0 & 0,0 & 0,0 \\
\hline Indeterminado & 5,8 & 0,0 & 2,7 & 2,4 & 3,0 & 1,9 & $\begin{array}{l}2,0 \\
2,3\end{array}$ & 0,0 & 1,7 & 3,1 & 2,4 & $\begin{array}{l}1,0 \\
1,0\end{array}$ & 2,4 & 0,0 & 2,0 & $\begin{array}{l}4,0 \\
4,7\end{array}$ & $\begin{array}{l}1,0 \\
1,9\end{array}$ & 0,8 & 3,8 & 5,0 \\
\hline Aglutinante indeterminado & 0,0 & 0,0 & 1,1 & 0,4 & 1,2 & 1,9 & 0,0 & 0,0 & 0,7 & 0,0 & 0,0 & 0,0 & 0,3 & 0,0 & 1,8 & 0,0 & 1,0 & 0,0 & 0,0 & 0,6 \\
\hline
\end{tabular}


Anexo 05 - Valores de ISQG e PEL para os HPAs, em $\mu \mathrm{g} . \mathrm{Kg}^{-1}$, de acordo com CCME (2002). O asterico $\left(^{*}\right)$ é usado para os hidrocarbonetos que não apresentam referências.

\begin{tabular}{|l|cc|}
\hline \multicolumn{1}{|c|}{ Compostos } & ISQG & PEL \\
\hline Acenafteno & 6,71 & 88,9 \\
Acenaftileno & 5,87 & 128 \\
Antraceno & 46,9 & 245 \\
Benzo(a)antraceno & 74,8 & 693 \\
Benzo(a)pireno & 88,8 & 763 \\
Benzo(b)fluoranteno & $*$ & $*$ \\
Benzo(k)fluoranteno & $*$ & $*$ \\
Benzo[g, h, i]perileno & $*$ & $*$ \\
Criseno & 108 & 846 \\
Dibenzo[a, h]antraceno & 6,22 & 135 \\
Fenantreno & 86,7 & 544 \\
Fluoranteno & 113 & 1494 \\
Fluoreno & 21,2 & 144 \\
Indeno[1, 2, 3-cd]pireno & $*$ & $*$ \\
Naftaleno & 34,6 & 391 \\
Pireno & 153 & 1398 \\
\hline
\end{tabular}


Anexo 06- Valores obtidos para os LCS, para os brancos do método e as taxas de recuperação dos respectivos surrogates durante as análises de HPAs presentes nos sedimentos do estudo.

\begin{tabular}{|c|c|c|c|c|c|c|}
\hline \multirow{2}{*}{ Compostos } & \multicolumn{2}{|c|}{ Resultados (\%) } & \multirow{2}{*}{\begin{tabular}{|c|} 
Limite de controle \\
de qualidade $(\%)$
\end{tabular}} & \multicolumn{2}{|c|}{ Resultados $(\mu \mathrm{g} / \mathrm{Kg})$} & \multirow{2}{*}{$\begin{array}{c}\text { Limite de } \\
\text { quantificação (LQ }\end{array}$} \\
\hline & LCS 1 & LCS 2 & & Branco 1 & Branco 2 & \\
\hline Acenafteno & 56 & 45 & $30-140$ & $<5,0$ & $<5,0$ & 5,0 \\
\hline Acenaftileno & 55 & 44 & $30-140$ & $<5,0$ & $<5,0$ & 5,0 \\
\hline Antraceno & 61 & 56 & $30-140$ & $<5,0$ & $<5,0$ & 5,0 \\
\hline Benzo(a)antraceno & 60 & 60 & $30-140$ & $<5,0$ & $<5,0$ & 5,0 \\
\hline Benzo(a)pireno & 70 & 69 & $30-140$ & $<5,0$ & $<5,0$ & 5,0 \\
\hline Benzo(b)fluoranteno & 69 & 71 & $30-140$ & $<5,0$ & $<5,0$ & 5,0 \\
\hline Benzo(k)fluoranteno & 62 & 56 & $30-140$ & $<5,0$ & $<5,0$ & 5,0 \\
\hline Benzo[g, h, i]perileno & 59 & 56 & $30-140$ & $<5,0$ & $<5,0$ & 5,0 \\
\hline Criseno & 57 & 55 & $30-140$ & $<5,0$ & $<5,0$ & 5,0 \\
\hline Dibenzo[a, $\mathrm{h}]$ antraceno & 41 & 41 & $30-140$ & $<5,0$ & $<5,0$ & 5,0 \\
\hline Fenantreno & 56 & 48 & $30-140$ & $<5,0$ & $<5,0$ & 5,0 \\
\hline Fluoranteno & 68 & 64 & $30-140$ & $<5,0$ & $<5,0$ & 5,0 \\
\hline Fluoreno & 57 & 47 & $30-140$ & $<5,0$ & $<5,0$ & 5,0 \\
\hline Indeno[1, 2,3-cd]pireno & 79 & 80 & $30-140$ & $<5,0$ & $<5,0$ & 5,0 \\
\hline Naftaleno & 57 & 45 & $30-140$ & $<5,0$ & $<5,0$ & 5,0 \\
\hline Pireno & 67 & 65 & $30-140$ & $<5,0$ & $<5,0$ & 5,0 \\
\hline \multirow{2}{*}{ Surrogates } & \multicolumn{2}{|c|}{ Resultados de recuperação (\%) } & Limite de controle & \multicolumn{2}{|c|}{ Resultados de recuperação (\%) } & Limite de controle \\
\hline & LCS 1 & LCS 2 & de qualidade $(\%)$ & Branco 1 & Branco 2 & de qualidade $(\%)$ \\
\hline 2-Fluorobifenil & 52 & 47 & $24-111$ & 48 & 65 & $24-111$ \\
\hline Terfenil-d14 & 63 & 69 & $25-110$ & 82 & 108 & $25-110$ \\
\hline
\end{tabular}


Anexo 07- Frequência relativa dos foraminíferos mortos e vivos encontrados nos sedimentos dos pontos controles.

\begin{tabular}{|c|c|c|c|c|}
\hline Estações & 1 & 1 & 2 & \\
\hline$M=$ mortos; $V=$ vivos & $\% \mathbf{M}$ & $\% \mathrm{~V}$ & $\% \mathbf{M}$ & $\% \mathrm{~V}$ \\
\hline fração 0.062 mm (quarteamento) & $1 / 8$ & 1 & $1 / 8$ & 1 \\
\hline Total analisado & 307 & 148 & 376 & 104 \\
\hline indivíduos. $\mathrm{cc}^{-1}$ & $2456 / 10$ & $148 / 20$ & $3008 / 10$ & $104 / 10$ \\
\hline indivíduos. $10 \mathrm{cc}^{-1}$ & 2456 & 74 & 3008 & 104 \\
\hline$n^{\circ}$ de espécies & 23 & 12 & 27 & 13 \\
\hline Diversidade de Shannon (H') & 2,63 & 1,62 & 2,58 & 2,14 \\
\hline Equitatividade de Shannon $\left(E_{\mathrm{H}^{\prime}}\right)$ & 0,84 & 0,65 & 0,78 & 0,86 \\
\hline Ammonia parkinsoniana & 6,5 & 19,6 & 6,4 & 17,3 \\
\hline Ammonia tepida & 12,4 & 56,1 & 16,5 & 39,4 \\
\hline Ammonia sp. & 1,3 & 5,4 & 1,9 & 3,8 \\
\hline Ammonia sp. juvenil & 2,9 & 0,7 & 1,6 & 1,0 \\
\hline Ammoscalaria sp. & 0,0 & 0,7 & 0,0 & 1,9 \\
\hline Bolivina compacta & 0,0 & 0,7 & 0,3 & 1,9 \\
\hline Bolivina danvillensis & 1,0 & 0,7 & 0,8 & 0,0 \\
\hline Bolivina doniezi & 1,3 & 2,7 & 1,1 & 1,0 \\
\hline Bolivina ordinaria & 0,7 & 0,0 & 0,8 & 1,0 \\
\hline Bolivina pulchella & 2,0 & 0,0 & 3,2 & 0,0 \\
\hline Bolivina sp. & 0,3 & 1,4 & 0,5 & 1,9 \\
\hline Brizalina striatula & 2,0 & 2,0 & 1,6 & 7,7 \\
\hline Buccela peruviana f. campsi & 0,0 & 0,0 & 1,1 & 0,0 \\
\hline Bulimina marginata & 5,5 & 0,0 & 4,8 & 0,0 \\
\hline Bulimina pupoides & 1,0 & 0,0 & 0,8 & 0,0 \\
\hline Bulimina sp. & 0,3 & 0,0 & 0,8 & 0,0 \\
\hline Buliminella elegantissima & 3,9 & 2,7 & 1,6 & 6,7 \\
\hline Cassidulina minuta & 1,6 & 0,0 & 1,6 & 0,0 \\
\hline Cassidulina sp. & 0,3 & 0,7 & 0,8 & 0,0 \\
\hline Cribroelphidium advenum & 2,3 & 0,7 & 1,3 & 1,0 \\
\hline Cribroelphidium discoidale & 1,3 & 0,0 & 0,3 & 0,0 \\
\hline Cribroelphidium excavatum & 3,3 & 0,7 & 2,4 & 1,0 \\
\hline Cribroelphidium gunteri & 1,0 & 0,0 & 1,3 & 0,0 \\
\hline Cribroelphidium poyeanum & 3,6 & 0,7 & 2,7 & 0,0 \\
\hline Cribroelphidium sp. & 2,9 & 0,0 & 2,4 & 0,0 \\
\hline Cribroelphidium sp. juvenil & 0,3 & 0,0 & 0,0 & 0,0 \\
\hline Cribrostomoides sp. & 0,0 & 0,7 & 0,0 & 0,0 \\
\hline Discorbis williamsoni & 1,3 & 0,0 & 1,1 & 0,0 \\
\hline Fissurina laevigata & 1,3 & 0,0 & 1,1 & 1,0 \\
\hline Fissurina sp. & 0,0 & 0,0 & 0,3 & 0,0 \\
\hline Gaudryina exilis & 0,0 & 0,0 & 0,8 & 0,0 \\
\hline Globigerinoides sp. & 0,0 & 0,0 & 0,3 & 0,0 \\
\hline Hanzawaia boueana & 0,7 & 0,0 & 0,8 & 0,0 \\
\hline Hopkinsina pacifica & 0,7 & 0,0 & 0,3 & 0,0 \\
\hline Lagena caudata & 0,0 & 0,0 & 0,3 & 0,0 \\
\hline Oolina sp. & 0,0 & 0,0 & 0,0 & 1,0 \\
\hline Pararotalia cananeiaensis & 32,9 & 0,0 & 35,1 & 3,8 \\
\hline Pseudononion atlanticum & 4,2 & 2,0 & 1,3 & 5,8 \\
\hline Pseudononion sp. & 0,3 & 0,0 & 0,3 & 0,0 \\
\hline Rolshauseni rolshauseni & 0,3 & 0,0 & 0,3 & 0,0 \\
\hline Textularia earlandi & 0,0 & 0,7 & 0,0 & 0,0 \\
\hline Textularia sp. & 0,0 & 0,7 & 0,3 & 1,0 \\
\hline Uvigerina peregrina & 0,0 & 0,0 & 0,0 & 1,0 \\
\hline Indeterminado & 0,7 & 0,7 & 1,6 & 0,0 \\
\hline Aglutinante indeterminado & 0,0 & 0,0 & 0,0 & 1,0 \\
\hline Total analisado & 100 & 100,0 & 100 & 100,0 \\
\hline
\end{tabular}


Anexo 08- Legenda das pranchas da área do emissário de Cigarras, São Sebastião, SP

\section{Prancha 1}

1. Ammonia parckinsoniana (lado espiral), $20 \mu \mathrm{m}$

2. Ammonia parckinsoniana (lado umbilical), $20 \mu \mathrm{m}$

3. Ammonia parckinsoniana (lado espiral), $20 \mu \mathrm{m}$

4. Ammonia parckinsoniana (lado umbilical), $20 \mu \mathrm{m}$

5. Ammonia tepida (lado espiral), $20 \mu \mathrm{m}$

6. Ammonia tepida (lado umbilical), $30 \mu \mathrm{m}$

7. Ammonia tepida (lado umbilical), $20 \mu \mathrm{m}$

8. Ammonia sp. (lado umbilical), $30 \mu \mathrm{m}$

9. Ammonia sp. deformada, $10 \mu \mathrm{m}$

10. Ammonia sp. juvenil, $20 \mu \mathrm{m}$

11. Ammoscalaria sp., $20 \mu \mathrm{m}$

12. Ammotium salsum, $10 \mu \mathrm{m}$

13. Bolivina doniezi, $20 \mu \mathrm{m}$

14. Bolivina ordinaria, $20 \mu \mathrm{m}$

15. Bolivina pulchella, $20 \mu \mathrm{m}$

16. Bolivina sp., $30 \mu \mathrm{m}$

17. Brizalina striatula, $30 \mu \mathrm{m}$

18.Buccella peruviana f. Campsi (lado umbilical), $30 \mu \mathrm{m}$

19. Bulimina marginata, $30 \mu \mathrm{m}$

20. Buliminella elegantissima, $10 \mu \mathrm{m}$ 


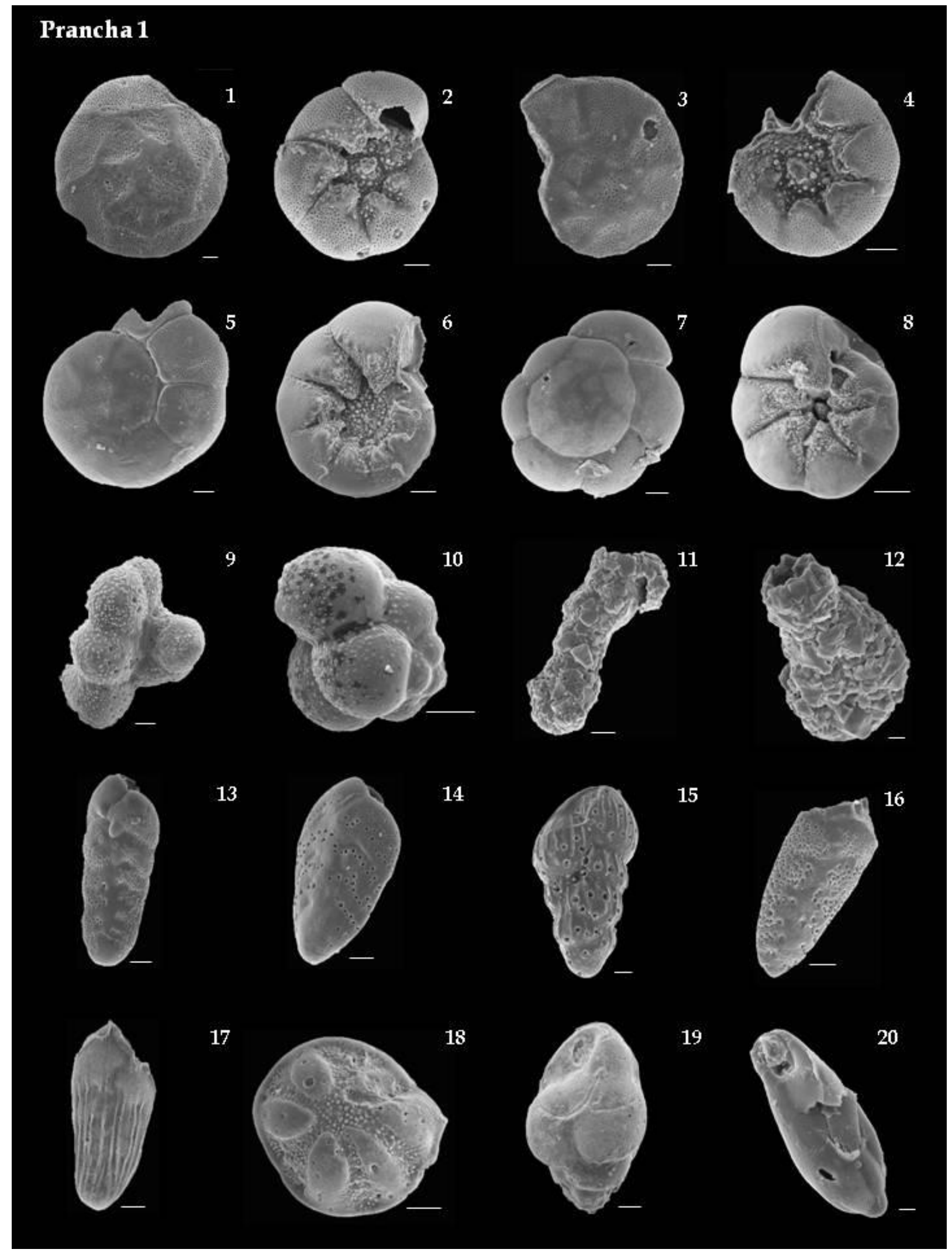




\section{Prancha 2}

1. Cassidulina crassa, $30 \mu \mathrm{m}$

2. Cassidulina sp., $20 \mu \mathrm{m}$

3. Cribroelphidium advenum, $20 \mu \mathrm{m}$

4. Cribroelphidium excavatum f. lidoensis, $10 \mu \mathrm{m}$

5. Cribroelphidium excavatum $\mathrm{f}$. clavata, $20 \mu \mathrm{m}$

6. Cribroelphidium gunteri, $100 \mu \mathrm{m}$

7. Cribroelphidium poyeanum, $20 \mu \mathrm{m}$

8. Cribroelphidium sp., $20 \mu \mathrm{m}$

9. Cribroelphidium sp., $20 \mu \mathrm{m}$

10. Cribrostomoides sp., $10 \mu \mathrm{m}$

11. Fissurina laevigata, $20 \mu \mathrm{m}$

12. Hanzawaia boueana (lado espiral), $20 \mu \mathrm{m}$

13. Lagena caudata, $10 \mu \mathrm{m}$

14. Neoconorbina terquemi (lado espiral), $20 \mu \mathrm{m}$

15. Pararotalia cananeiaensis, $20 \mu \mathrm{m}$

16. Pseudononion atlanticum, $20 \mu \mathrm{m}$

17. Quinqueloculina patagonica, $10 \mu \mathrm{m}$

18. Rolshauseni rolshauseni (lado espiral), $30 \mu \mathrm{m}$

19. Textularia earlandi, $100 \mu \mathrm{m}$

20. Uvigerina peregrina, $20 \mu \mathrm{m}$ 


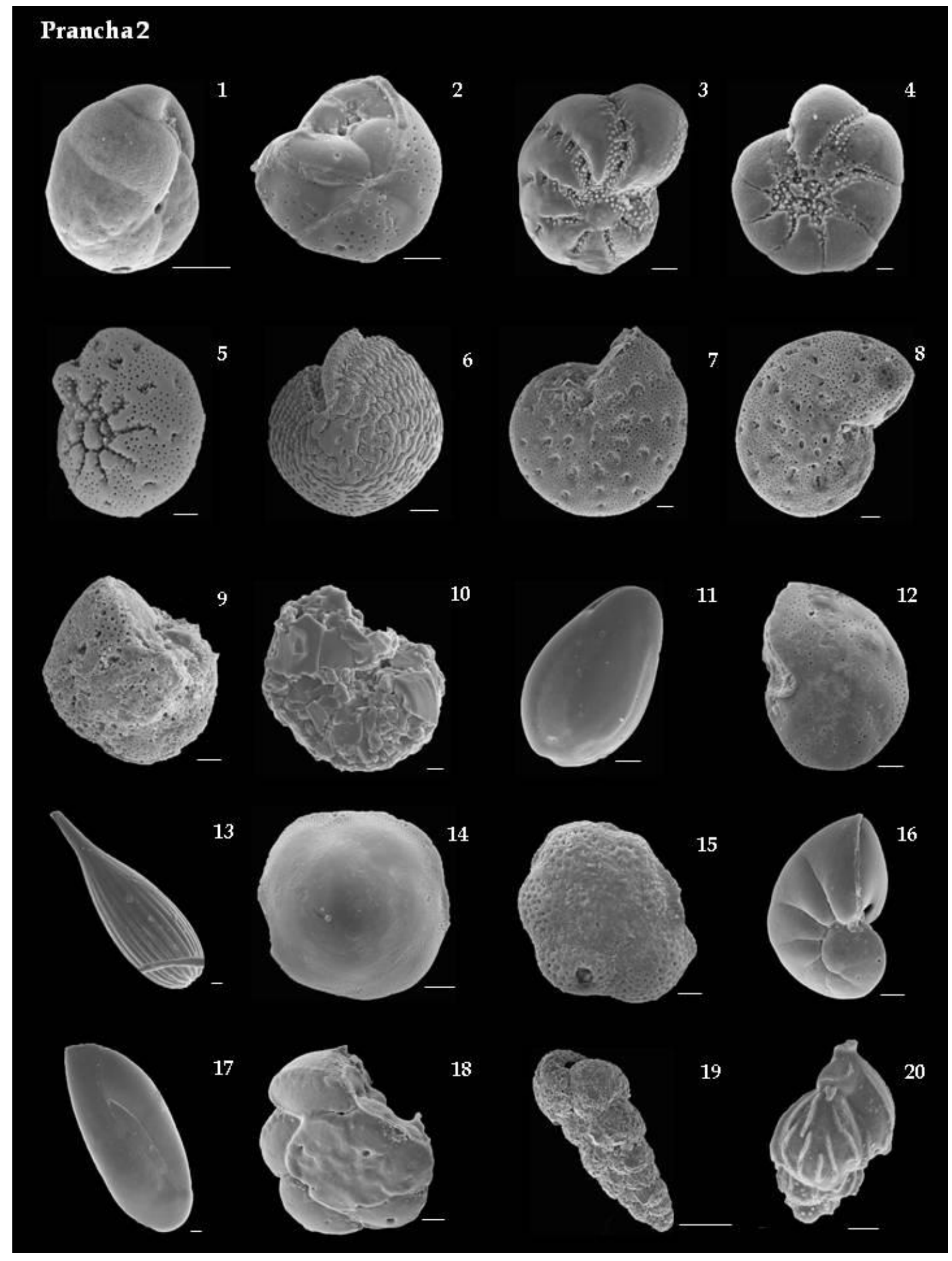

